\title{
An uneven balance?
}

Citation for published version (APA):

Nguyen, H-T. (2018). An uneven balance? A legal analysis of power asymmetries between National Parliaments in the EU. [Doctoral Thesis, Maastricht University]. Eleven International. https://doi.org/10.26481/dis.20180525hn

Document status and date:

Published: 01/01/2018

DOI:

10.26481/dis.20180525hn

Document Version:

Publisher's PDF, also known as Version of record

\section{Please check the document version of this publication:}

- A submitted manuscript is the version of the article upon submission and before peer-review. There can be important differences between the submitted version and the official published version of record.

People interested in the research are advised to contact the author for the final version of the publication, or visit the DOI to the publisher's website.

- The final author version and the galley proof are versions of the publication after peer review.

- The final published version features the final layout of the paper including the volume, issue and page numbers.

Link to publication

\footnotetext{
General rights rights.

- You may freely distribute the URL identifying the publication in the public portal. please follow below link for the End User Agreement:

www.umlib.nl/taverne-license

Take down policy

If you believe that this document breaches copyright please contact us at:

repository@maastrichtuniversity.nl

providing details and we will investigate your claim.
}

Copyright and moral rights for the publications made accessible in the public portal are retained by the authors and/or other copyright owners and it is a condition of accessing publications that users recognise and abide by the legal requirements associated with these

- Users may download and print one copy of any publication from the public portal for the purpose of private study or research.

- You may not further distribute the material or use it for any profit-making activity or commercial gain

If the publication is distributed under the terms of Article $25 \mathrm{fa}$ of the Dutch Copyright Act, indicated by the "Taverne" license above, 


\title{
An uneven balance?
}

\author{
Citation for published version (APA):
}

Nguyen, H-T. (2018). An uneven balance? A legal analysis of power asymmetries between National Parliaments in the EU. https://doi.org/10.26481/dis.20180525hn

\section{Document status and date:}

Published: 01/01/2018

DOI:

10.26481/dis.20180525hn

\section{Document Version:}

Publisher's PDF, also known as Version of record

\section{Please check the document version of this publication:}

- A submitted manuscript is the version of the article upon submission and before peer-review. There can be important differences between the submitted version and the official published version of record.

People interested in the research are advised to contact the author for the final version of the publication, or visit the DOI to the publisher's website.

- The final author version and the galley proof are versions of the publication after peer review.

- The final published version features the final layout of the paper including the volume, issue and page numbers.

Link to publication

\section{General rights}

Copyright and moral rights for the publications made accessible in the public portal are retained by the authors and/or other copyright owners and it is a condition of accessing publications that users recognise and abide by the legal requirements associated with these rights.

- Users may download and print one copy of any publication from the public portal for the purpose of private study or research.

- You may not further distribute the material or use it for any profit-making activity or commercial gain

- You may freely distribute the URL identifying the publication in the public portal.

If the publication is distributed under the terms of Article $25 \mathrm{fa}$ of the Dutch Copyright Act, indicated by the "Taverne" license above, please follow below link for the End User Agreement:

www.umlib.nl/taverne-license

Take down policy

If you believe that this document breaches copyright please contact us at:

repository@maastrichtuniversity.nl

providing details and we will investigate your claim. 
An Uneven Balance? 



\title{
AN Uneven Balance?
}

\author{
A Legal Analysis of Power Asymmetries between \\ National Parliaments in the EU
}

\begin{abstract}
DISSERTATION
TO ObTAin The Degree of Doctor at MaAstricht

UNIVERS I T Y,

ON THE AUthority OF The Rector Magnificus,

PROF. DR. RIANNE M. LETSCHERT

IN ACCORDANCE WITH THE DECISION OF THE BOARD OF DEANS,

TO BE DEFENDED IN PUBLIC

ON FRIDAY 25 MAY 2018 , AT $10.00 \mathrm{H}$ HURS
\end{abstract}

B Y

HOA I-THU NGUYEN 
Supervisor(s):

Prof. dr. A.W. Heringa

Co-supervisor:

Dr. W. van der Woude (Utrecht University)

\section{Assessment Committee:}

Prof. dr. B.E.F.M. de Witte (Chair)

Prof. dr. M. Dawson (Hertie School of Governance)

Dr. S. Hardt

Prof. mr. L.F.M. Verhey (Leiden University)

This research project was partially financed by the Montesquieu Institute Maastricht. 


\section{ACKNOWLeDgments}

This book is about the role of national parliaments in the EU, in particular the power asymmetries that exist between the different parliaments and how these asymmetries affect representative democracy in the EU. Almost five years ago, when I submitted the research proposal for this project, the topic was a completely different one - and to this day and for that reason many close friends and colleagues are still surprised when they learn the present title of this book. From the beginning of the book in 2013 until its final draft in spring 2018, it was not only my thesis project that has gone through considerable changes but also I have learned a lot in the process, both on a professional and on a personal level.

My gratitude goes first and foremost to my promotors, Aalt Willem Heringa and Wytze van der Woude. Without their guidance and their firm belief in the book's value even when I had my doubts the writing process would have been indefinitely more difficult. I also wish to thank Bruno de Witte, Mark Dawson, Luc Verhey and Sascha Hardt for agreeing to read this thesis and for providing valuable comments on the manuscript.

I am incredibly thankful to my paranymph Sofie Wolf, without whom I cannot imagine work and life in Maastricht. In the last four years we shared not only an office but also the same sense of frustration that sometimes comes with writing a doctoral thesis, and she has become my closest companion in the academic world and outside. I am almost certain that we both could have finished our PhDs earlier if we had spent less time on visits to Coffeelovers and on constantly (re-)decorating the interior of our office according to the different seasons outside (never will be forgotten that time when we searched the Faculty grounds for pinecones and chestnuts to use for our fall decorations), but we also would have had much less fun in the process.

I would like to extend my warmest gratitude to Mariolina Eliantonio and Sascha Hardt for their friendship and support throughout the last five years and for always kindly and generously sharing their experience and expertise with me - and to Mariolina in particular for keeping me company in the various cafés of Brussels during the final stages of revision for this $\mathrm{PhD}$.

I would also like to thank my colleagues at the Law Faculty and the Department of Public Law, who have made my time in Maastricht much more enjoyable than it otherwise would have been without them - in particular Antonia Waltermann, whose advice on many aspects of this book were invaluable, Damla Cavusoglu-Bos and Lotte Meurkens but also all the other great colleagues with whom I have had the pleasure to work.

And because life is more than just the $\mathrm{PhD}$ - even though at times it certainly felt different - I will forever be thankful to my friends and family for their support during this period of my life, for regularly cheering me up and for always welcoming me in their homes 
whenever I felt the need to escape from my PhD: Laura, Lena, Nina, Eva, Valentina, Bao-Hoa, Maike, Jonas, Frieda (even though she will not remember it) and everybody else who was there for me during the last five years.

Finally, and most importantly, I am grateful beyond words to my parents and my sister Mai for their love and support throughout.

Thu Nguyen

Maastricht, February 2018 


\section{Table of Contents}

$\begin{array}{lll}\text { Abbreviations } & \text { xv }\end{array}$

1 Introduction 1

1.1 Introduction 1

1.2 Representative democracy 2

1.3 European Parliament and national parliaments as citizens' representatives 3

1.3.1 European Parliament 3

1.3.2 National parliaments 4

1.4 The asymmetric impact of the crisis on parliamentary powers and the resulting implications for representative democracy in the EU 6

$\begin{array}{lll}1.5 & \text { Research question and methodology } & 7\end{array}$

2 Representative democracy 11

2.1 Introduction 11

2.2 The concept of representative democracy 12

2.3 Representation: Responsiveness vs. responsibility 13

$\begin{array}{ll}\text { 2.3.1 Responsiveness } & 13\end{array}$

2.3.1.1 Principal-agent theory in democratic systems 14

$\begin{array}{ll}\text { 2.3.1.2 The concept of accountability } & 17\end{array}$

$\begin{array}{ll}2.3 .2 \text { Responsibility } & 18\end{array}$

2.4 Representative democracy in the EU 20

3 Parliaments in the European Union $\quad 25$

$\begin{array}{lll}3.1 & \text { Introduction } & 25\end{array}$

3.2 The European Parliament and national parliaments 27

3.3 The debate on the role of parliaments in the EU 28

3.3.1 First phase: 1950s - 1970s 28

3.3.1.1 ECSC and EC: An international organization 28

3.3.1.2 Direct elections of the European Parliament: Separating the national and European parliamentary mandates 30

3.3.1.3 1970s: Increasing budgetary powers for the European Parliament and the beginning of adaptation in national parliamentary chambers 
3.3.2 Second phase: $1980 \mathrm{~s}-1990 \mathrm{~s}$

3.3.2.1 SEA: Shift towards supranational powers and a loss of national parliamentary powers

3.3.3 Third phase: Since mid-1990s

3.3.3.1 EU: A genuine political public power and the recognition of the role of national parliaments at EU level

3.4 National parliaments under the Treaty of Lisbon 42

3.4.1 Powers entrenched in EU primary law 43

$\begin{array}{lll}\text { 3.4.1.1 Information rights } & 43\end{array}$

3.4.1.2 Early Warning Mechanism $\quad 43$

$\begin{array}{lll}\text { 3.4.1.3 Political dialogue } & 46\end{array}$

3.4.1.4 Ratification of Treaty amendments $\quad 47$

3.4.1.5 Interparliamentary cooperation under Protocol $\mathrm{No}^{\circ} 1$

3.4.1.6 Other forms of interparliamentary cooperation 48

$\begin{array}{lll}3.4 .1 .7 & \text { IPEX } & 50\end{array}$

3.4.1.8 Permanent representatives in Brussels $\quad 50$

3.5 The European Parliament under the Treaty of Lisbon 51

$\begin{array}{ll}\text { 3.5.1 Legislative powers } & 51\end{array}$

3.5.1.1 Ordinary legislative procedure $\quad 51$

3.5.1.2 Right to initiative $\quad 52$

3.5.1.3 Special legislative procedures $\quad 52$

3.5.1.4 Other forms of parliamentary involvement in decisionmaking 52

3.5.1.5 The European Parliament and secondary legislation 53

3.5.2 Budgetary powers $\quad 55$

3.5.3 Scrutiny powers $\quad 56$

3.5.3.1 The European Parliament and the Commission 56

3.5.3.2 The European Parliament and the Council of Minis-

3.5.3.3 The European Parliament and the European Council 61

3.5.3.4 The European Parliament and the European Central Bank 63

3.5.4 Powers of the European Parliament in the EMU 64

3.6 Concluding remarks 66 
4 The German Bundestag

4.1 Introduction 69

4.2 Conceptualizing national parliamentary control in the EU 70

4.2.1 Powers of national parliaments entrenched in domestic law $\quad 70$

$\begin{array}{ll}\text { 4.2.2 Instruments of parliamentary control } & 71\end{array}$

4.2.2.1 Right to information $v i s$ - $a$-vis the national governments and European Affairs Committees 72

$\begin{array}{lll}\text { 4.2.2.2 Scrutiny reserves and mandating systems } & 73\end{array}$

4.3 The German Bundestag $\quad 75$

4.3.1 The right to demand information $\quad 76$

4.3.1.1 The right to summon the government 76

$\begin{array}{lll}\text { 4.3.1.2 The right to ask questions } & 76\end{array}$

4.3.1.3 Major interpellations (Große Anfragen) $\quad 78$

4.3.1.4 Minor interpellations (Kleine Anfragen) 78

4.3.1.5 Questions by individual MdB (Fragen einzelner Mitglieder des Bundestages) 79

4.3.1.5.1 Written questions (Schriftliche Einzelfragen) 79

4.3.1.5.2 Oral questions (Fragestunden) 79

4.3.1.6 Matters of topical interest (Thema von allgemeinem
aktuellem Interesse)

4.3.1.6.1 Debates on matters of topical interests (Aktuelle Stunde) 80

4.3.1.6.2 Questions put to the government

(Befragung der Bundesregierung) $\quad 80$

4.3.1.7 Overview over number of questions asked by the Bundestag

4.3.2 The participation of the Bundestag in matters concerning the

European Union (Angelegenheiten der Europäischen Union)

4.3.2.1 Right to be informed on matters concerning the European Union $\quad 84$

4.3.2.2 Scope of 'matters concerning the European Union' $\quad 85$

4.3.2.3 'Comprehensive' 86

4.3.2.3.1 Quality of the information 86

4.3.2.3.2 Quantity of the information 89

4.3.2.4 'At the earliest time possible' 90

4.3.2.5 Formal requirements 90

4.3.2.6 Limits to the right of information 91

4.3.2.7 The Liaison Office (Verbindungsbüro) 92 
4.3.3 The ability of the Bundestag to process information 93

4.3.3.1 European Affairs Committee 94

4.3.3.2 The powers of the EAC 94

4.3.3.3 The frequency of EAC meetings 95

4.3.3.4 Internal staff and resources 96

4.3.4 The power to influence the government 98

4.3.4.1 Scrutiny reserve and mandating procedures 99

4.3.4.2 (Practical) Limits to the mandating rights of the Bundestag 102

4.3.4.3 Obligation of the government to obtain prior parliamentary consent in matters concerning the ESM and EFSF

$\begin{array}{lll}\text { 4.3.4.4 Plenary debates } & 103\end{array}$

4.3.5 The right to sanction the government 106

$\begin{array}{ll}4.4 \text { Concluding remarks } & 107\end{array}$

5 Chapter: The Irish Dáil Éireann 111

$\begin{array}{lll}5.1 & \text { Introduction } & 111\end{array}$

5.2 The Irish Dáil Éireann 112

5.2.1 The right to demand information $\quad 112$

5.2.1.1 The right to summon the government 112

$\begin{array}{ll}\text { 5.2.1.2 The right to ask questions } & 113\end{array}$

$\begin{array}{lll}\text { 5.2.1.3 Written questions } & 113\end{array}$

$\begin{array}{lll}\text { 5.2.1.4 Oral questions } & 113\end{array}$

5.2.2 The participation of the Dáil Éireann in European Union matters 115

5.2.2.1 The European Scrutiny Act $2002 \quad 115$

5.2.2.2 The European Union Act 2009

5.2.3 The ability of the Dáil Éireann to process information 118

$\begin{array}{lll}\text { 5.2.3.1 The Irish committee system } & 118\end{array}$

5.2.3.2 The Joint Committee on European Union Affairs 119

5.2.3.3 The powers of the Joint Committee 122

5.2.3.4 Number of documents considered by the Joint Committee 125

5.2.3.5 The role of the committees in scrutinizing (European) Council meetings $\quad 126$

$\begin{array}{ll}\text { 5.2.3.6 Internal staff and resources } & 127\end{array}$

$\begin{array}{ll}\text { 5.2.4 The power to influence the government } & 128\end{array}$

$\begin{array}{ll}\text { 5.2.4.1 Scrutiny reserve and mandating procedures } & 128\end{array}$ 
5.2.4.2 Obligation of the government to obtain prior parliamentary consent in matters concerning the ESM and EFSF

5.2.4.3 Plenary debates

5.2.5 The right to sanction the government 134

$\begin{array}{ll}5.3 \text { Concluding and comparative remarks } & 135\end{array}$

6 The asymmetric impact of the crisis on national parliaments 139

$\begin{array}{lll}6.1 & \text { Introduction } & 139\end{array}$

6.2 National parliaments in times of crisis $\quad 140$

6.2.1 The asymmetric impact of the crisis 142

6.2.1.1 Eurozone vs. non-Eurozone 144

6.2.1.2 Within the Eurozone: Weak vs. strong national parliaments 152

6.2.1.3 Asymmetry according to institutional strength 153

6.2.1.3.1 Ratification of intergovernmental treaties 153

6.2.1.3.2 Participation in EU (crisis) affairs 154

6.2.1.3.3 Control over European Council meetings $\quad 156$

6.2.1.3.4 Control over Euro summits $\quad 158$

6.2.1.4 Asymmetry according to economic strength 159

6.2.1.4.1 The European Council and the asymmetric bargaining powers of Member

States

159

6.2.1.4.2 Institutionalized asymmetric powers between 'creditor' and 'debtor' countries

6.2.2 Non-Eurozone: TSCG signatories vs. non-signatories 165

6.3 Consequences for EU dual strands of representation 168

$\begin{array}{ll}6.4 \text { Concluding remarks } & 170\end{array}$

7 Representative democracy in the EU - Which way forward? 171

$\begin{array}{lll}7.1 & \text { Introduction } & 171\end{array}$

$\begin{array}{lll}7.2 & \text { Representative democracy in the EU } & 172\end{array}$

7.2.1 Consequences for representative democracy in the EMU 173

$\begin{array}{lll}7.3 & \text { Reform proposals for democracy in the EMU } & 177\end{array}$

7.3.1 Strengthening the position of the European Parliament in the EMU 
7.3.1.1 Equalization of the European Parliament with the Council

7.3.1.2 Stronger involvement of the European Parliament in the European Semester

7.3.1.3 Stronger scrutiny powers $v i s-\grave{a}$-vis a newly established EU Minister of Finance

7.3.1.4 Differentiated European Parliament

7.3.1.5 Shortcomings in the representativeness of the European Parliament

7.3.2 Separate parliamentary assembly for the Eurozone

7.3.3 Strengthening the national parliaments through interparliamentary cooperation

7.3.3.1 Conference of Speakers of the European Union Parliaments

7.3.3.2 COSAC (Conference of European Affairs Committees)

7.3.3.3 Joint meetings on topics of common interest

7.3.3.4 Meetings of sectoral committees

7.3.3.5 Common Foreign Security Policy and Common Security and Defence Policy Conference

7.3.3.6 Interparliamentary Conference on Economic Governance of the European Union

7.3.3.7 Establishing a new interparliamentary conference for the Eurozone

7.3.3.8 Obstacles to establishing a new interparliamentary conference

7.3.4 Interparliamentary cooperation as the way forward?

8.2 Recommendations for the future: Interparliamentary cooperation as the way forward? 
TABLE of CONTENTS

Addendum on Valorization 251 



\section{Abbreviations}

AFSJ

AGS

AMR

AbgG

BBG

BEPG

BMWi

BUDG

BVerfG

CFSP

CJEU

CODACC

COFACC

COREPER

COSAC

CSDP

CSR

DBP

DIP

EAC

EC

ECB

ECJ

ECOFIN
Area of Freedom, Security and Justice

Annual Growth Survey

Alert Mechanism Report

Act Regulating the Status of the Members of the

German Bundestag (Gesetz über die

Rechtsverhältnisse der Mitglieder des Deutschen

Bundestages)

Federal Civil Service Act (Bundesbeamtengesetz)

Broad Economic Policy Guidelines

Federal Ministry for Economic Affairs and Energy

(Bundesministerium für Wirtschaft und Energie)

European Parliament Committee on Budgets

German Federal Constitutional Court

(Bundesverfassungsgericht)

Common Foreign and Security Policy

Court of Justice of the European Union

Conference of Foreign Affairs Committee

Chairpersons

Conference of Defence Affairs Committee

Chairpersons

Committee of Permanent Representatives

Conference of Parliamentary Committees for Union

Affairs of Parliaments of the European Union

Common Security and Defence Policy

Country-Specific Recommendation

Draft Budgetary Plan

Parliamentary Material Information System

(Dokumentations- und Informationssystem für

Parlamentarische Vorgänge)

European Affairs Committee

European Communities

European Central Bank

European Court of Justice

Economic and Financial Affairs Council 
ECON

ECSC

ED

EDP

EEC

EFSF

EFSM

EIB

EIP

EMPL

EMU

EP

EPW

ERM

ES

ESCB

ESM

ESMFinG

EU

EUZBBG

EWM

FC

GDP

GG

GNP

ICM

IGC

IMF

IPEX
European Parliament Committee on Economic and Monetary Affairs

European Coal and Steel Communities

Economic Dialogue

Excessive Deficit Procedure

European Economic Community

European Financial Stability Facility

European Financial Stabilisation Mechanism

European Investment Bank

Excessive Imbalance Procedure

European Parliament Committee on Employment and Social Affairs

Economic and Monetary Union

European Parliament

European Parliamentary Week

European Exchange Rate Mechanism

European Semester

European System of Central Banks

European Stability Mechanism

Act on Financial Participation in the European

Stability Mechanism (Gesetz zur finanziellen

Beteiligung am Europäischen

Stabilitätsmechanismus)

European Union

Act on Cooperation between the Federal

Government and the German Bundestag in Matters concerning the European Union (Gesetz über die Zusammenarbeit von Bundesregierung und

Deutschem Bundestag in Angelegenheiten der

Europäischen Union)

Early Warning Mechanism

Fiscal Compact

Gross Domestic Product

German Basic Law (Grundgesetz)

Gross National Product

Interparliamentary Committee Meetings

Intergovernmental Conference

International Monetary Fund

Interparliamentary EU Information Exchange 
IntVG

JCM

JHA

JPM

MEP

MIP

MP

MS

MTO

$\mathrm{MdB}$

$\mathrm{MoU}$

NP

NRP

OLP

PD

QMV

RQMV

RoP

SCP

SEA

SGP

STV

StabMechG

TD

TEU

TFEU

TSCG
Act on the Exercise by the Bundestag and by the Bundesrat of their Responsibility for Integration in Matters concerning the European Union (Gesetz über die Wahrnehmung der Integrationsverantowrtung des Bundestages und des Bundesrates in Angelegenheiten der Europäischen Union)

Joint Committee Meetings

Justice and Home Affairs

Joint Parliamentary Meetings

Member of the European Parliament

Macroeconomic Imbalance Procedure

Member of Parliament

Member State

Medium-Term Objective

Member of the German Bundestag (Mitglied des

Deutschen Bundestages)

Memorandum of Understanding

National Parliament

National Reform Programme

Ordinary Legislative Procedure

Political Dialogue

Qualified Majority Voting

Reverse Qualified Majority Voting

Rules of Procedure

Stability or Convergence Programme

Single European Act

Stability and Growth Pact

Single Transferable Vote

Act on the Assumption of Guarantees within the Framework of a European Stabilisation Mechanism (Gesetz zur Übernahme von Gewährleistungen im Rahmen eines europäischen

Stabilisierungsmechanismus)

Member of the Irish Dáil Éireann (Teachta Dála)

Treaty on European Union

Treaty on Functioning of European Union

Treaty on Stability, Coordination and Governance

in the Economic and Monetary Union 



\section{INTRODUCTION}

\subsection{INTRODUCTION}

Instead of the functioning of governing, for which it is radically unfit, the proper office of a representative assembly is to watch and control the government, to throw the light of publicity on its acts; to compel a full exposition and justification of all of them which any considers questionable; to censure them if found condemnable.

(John Stuart Mill, 1861) ${ }^{1}$

There was a public outcry when it became known in November 2011 that the Irish draft budget had been sent to a committee of the German Bundestag before it was even presented to the Irish parliament, and claims were made that the Irish government had surrendered its sovereignty to other European governments. ${ }^{2}$ The European sovereign debt crisis, or Eurozone crisis, was not only a financial and monetary crisis; it was also a democratic crisis.

Ireland was the first Member State to request financial assistance under the European Financial Stability Facility (EFSF) - which has since been replaced by the permanent European Stability Mechanism (ESM) - in 2010. In return for the $€ 17.7$ billion provided by the EFSF, ${ }^{3}$ the Irish parliament was obligated to sign a so-called Memorandum of Understanding $(\mathrm{MoU})$, agreeing to a series of conditions and structural reforms laid down in the economic adjustment programme that were aimed at improving Ireland's financial sector and public finances. ${ }^{4}$ This included the obligation to present its draft budget to the troika, i.e., the European Commission, the International Monetary Fund and the European Central Bank, as part of the monitoring process through these three institutions of the implementation of the conditionalities set out in the MoU. It seems most likely that the draft budgetary plan was forwarded to the German parliament because of a ruling that was rendered by the German Bundesverfassungsgericht (BVerfG) in September 2011,

1 J.S. Mill, Considerations on Representative Government, Serenity Publishers: USA, 2008 [1861], p. 69.

2 Financial Times website, Irish angry over budget leak to Germany, available at: <https://www.ft.com/content/bd9ab93a-11fb-11e1-a114-00144feabdc0> (last retrieved on 31 July 2017); The Guardian website, Ireland's budget leak to Germany brings home some harsh realities, available at: <https://www.theguardian.com/commentisfree/2011/nov/18/ireland-budget-germany-leak> (last retrieved on 31 July 2017).

3 The remainder of the $€ 67.5$ billion rescue package for Ireland was supplied by the European Union, the individual EU Member States and the IMF.

4 European Commission, Directorate-General for Economic and Financial Affairs, Economic Adjustment Programme for Ireland, (2011) Occasional Papers 76. 
whereby it made any further financial assistance under the rescue mechanisms conditional upon parliamentary approval, ${ }^{5}$ including the right of the Budget Committee of the German Bundestag to be informed on a quarterly basis on the guarantees given and the correct use thereof. ${ }^{6}$ While this requirement considerably strengthened the position of the German Bundestag in relation to budgetary matters at the EU level, the fulfillment of the obligation imposed by the Bundesverfassungsgericht also meant, at the same time, an encroachment upon another Member States' parliamentary rights, which (as in the Irish case) saw its own national budget being scrutinized by another parliament.

The Irish case is the perfect illustration of a situation, whereby the constitutional obligations of one parliament during the European debt crisis can have democratic implications for another parliament, even though both are supposed to be equally sovereign in their rights. This divergence of national parliamentary powers in the EU is a central part of this book. The focus of this book is on analyzing and understanding the formal power asymmetries that exist between national parliaments in the EU and on considering the implications of such asymmetries for representative democracy in the EU. It takes the European sovereign debt crisis as a cause to look into this particular issue because of the asymmetric impact that it had on the different national parliaments but not necessarily as the point of main focus of the research. As an addition to this analysis, the book in the end also illustrates how the negative implications for EU representative democracy that result from the described power asymmetries between national parliaments could be mitigated by evaluating different ideas that have been put forward in this regard.

\subsection{REPRESENTATIVE DEMOCRACY}

Article 10(1) TEU states that the "functioning of the Union shall be founded on representative democracy." EU citizens are directly represented at EU level by the European Parliament, while Member States are represented in the European Council by their Heads of State or Government and in the Council by their governments, who in turn are democratically accountable to their national parliaments at home (Article 10(2) TEU). Generally speaking, representative democracy means that those who govern (the representatives) are elected by those who are governed (the represented) at regular intervals, as opposed to the latter governing themselves as would be the case in a direct democracy. ${ }^{7}$ It also means

5 BVerfG, Judgment of 07 September 2011 - 2 BvR 987/10.

6 Act on the Assumption of Gurarantees within the Framework of a European Stabilisation Mechanism (Stabilisation Mechanism Act - StabMechG) of 22 May 2010 (Federal Law Gazette I, p. 627), as amended by Article 1 of the Act of 9. October 2011 (Federal Law Gazette I, p. 1992), Section 5(5).

7 B. Manin, The Principles of Representative Government, Cambridge University Press: United Kingdom, 1997, p. 6. 
that the representatives must act in the best interests of those represented and to be responsive to their needs. ${ }^{8}$ This concept will be explored in more detail in Chapter 2.

\subsection{European Parliament and national parliaments as Citizens' REPRESENTATIVES}

While in nation-states the role of the representatives and those represented is, on the whole, clearly demarcated; this is not the case in the European Union. Rather than having only one representative organ, all citizens are represented by both the European Parliament and their national parliaments at home.

\subsubsection{European Parliament}

The European Parliament is the representative organ at European Union level, representing the interests of all EU citizens. The development of the European Parliament, from its beginnings as the Common Assembly of the European Coal and Steel Community composed of parliamentarians from the six national parliaments of the founding Member States and accorded with very few powers - to the co-legislator that it is today under the Treaty of Lisbon, is well-documented. It now acts in approximately $90 \%$ of cases on an equal footing with the Council in the EU decision-making process, ${ }^{9}$ even though the right of initiative in the EU is still exclusively reserved for the Commission. Where a policy area does not fall under the ambit of the ordinary legislative procedure, the involvement of the EP is limited to either consultation or approval, depending on the specific procedure that is to be applied. The European Parliament's budgetary power includes its power of consent to the budget as well as its right to discharge the Commission's expenses. It also exercises supervisory functions over the other EU institutions, most notably the European Commission, which as a body must be voted into office by the EP (Article 17(7) TEU). As was demonstrated in the 2014 EP elections, the choice of nominee for Commission President by the European Council is dependent on the outcome of the European parliamentary elections. Once in office, the Commission then remains accountable to the European Parliament and it can be removed en bloc through a motion of censure.

In general, the European Parliament, as the only directly elected institution of the European Union, fulfills most of the functions that are associated with parliaments in nation-states - namely legislative, budgetary and scrutiny functions. There are also some

8 H. Pitkin, The Concept of Representation, University of California Press: United States, 1967, p. 209.

9 B. De Witte, A.H. Trechsel, D. Damjanovic, E. Hellquist, J. Hien, P. Ponzano, "Legislating after Lisbon New Opportunities for the European Parliament", (2010) Study prepared in the framework of the European Union Democracy Observatory (EUDO), Florence, p. 26. 
drawbacks, however. The European Parliament is often said not to be able to render the EU fully democratic because - even though it is directly elected - its elections are considered to be second-order elections in comparison to national parliamentary elections. ${ }^{10}$ Secondorder elections are perceived to be less important than first-order elections, with the latter being regarded as decisive for policy-making. The turnout at European parliamentary elections is consistently lower than at national level and campaigns are more focused on national issues rather than pan-European concerns. This is also due to the fact that the EP is not uniformly elected on the basis of an EU-wide list, but rather on a national basis within the different Member States.

Nevertheless, and despite these shortcomings, the European Parliament normatively constitutes one strand of democratic representation in the EU, with national parliaments being the other. As the EU has gradually moved away from being regarded as an international organization to being regarded as a supranational organization, the role and powers of the EP were expanded upon in order to adapt to these changes. Because the process of European integration has led to a continuous erosion of parliamentary powers at the national level in favour of the European institutions and the national executive, the focus for a long time was on strengthening the position of the European Parliament - which was most notably advocated by the EP itself ${ }^{11}$ - as a remedy for the alleged democratic deficit resulting from this development.

\subsubsection{National parliaments}

National parliaments represent the citizens of their respective Member States at EU level by holding their national representatives in the Council and European Council to account. The role of national parliaments, by way of contrast to the role of the EP, was not part of the discussion surrounding the EU's democratic credentials at the supranational level for some time. The shift of competences to the EU level and the nature of the EU decisionmaking process has led to the erosion of national parliamentary powers to the benefit of EU institutions and national executives. Often categorized as the 'latecomers' or 'losers' of integration, ${ }^{12}$ national parliaments have started to adapt their procedures to reflect the changes that have been brought about by the European integration process since the 1980s, but it was not until the Treaty of Maastricht that they were explicitly mentioned in the declarations annexed to the Treaties. Because the European Parliament was, by itself, not

10 See, for example: H. Schmitt, “The European Parliament Elections of June 2004: Still Second-Order?”, (2005) 28 West European Politics, pp. 650-679.

11 See: R. Corbett, F. Jacobs, M. Shackleton, "The European Parliament at Fifty: A View from the Inside", (2003) 41 Journal of Common Market Studies, pp. 353-373.

12 See: A. Maurer, W. Wessels (eds.), National Parliaments on their Ways to Europe: Losers or Latecomers?, Nomos: Baden-Baden, 2001. 
able to remedy the EU's democratic deficit - the perceived increase of which was sometimes labeled a 'deparliamentarization process', ${ }^{13}$ - the role of national parliaments in the EU was considered to be a solution to the problem. Thus, the Laeken declaration of 2001 included national parliaments as one of the issues to be discussed in the context of future Treaty reforms. ${ }^{14}$

Article 12 TEU now states that national parliaments "contribute actively to the good functioning of the Union." As per the Treaty of Lisbon, national parliaments have two main tasks. At the national level, the function of national parliaments is to hold their executive to account for actions that take place at EU level, i.e., in the Council and European Council, in accordance with their respective national constitutional rules. In addition to this traditional role of national parliaments in the EU, the Treaty of Lisbon also introduced a subsidiarity control mechanism, which allows national parliaments - under certain circumstances - to object to legislative proposals on the grounds of subsidiarity. ${ }^{15}$

Under the Treaty of Lisbon, the powers of national parliaments are the same for all parliaments - in addition to the subsidiarity control, national parliaments also have for example, inter alia, a right to information and they are also involved in Treaty amendments. However, the extent of their influence on EU decision-making powers through the national governments depends on their respective constitutional rules, under which they are operating. By scrutinizing the activities of the national executive and their activities at the European level, national parliaments are supposed to ensure a link between their national electorates and the national government acting at EU level and thereby to contribute to the democratic legitimacy of the EU decision-making process. However, the extent to which national parliaments are able or willing to control and influence their ministers in the Council varies very much from one parliament to the next. This can either be due to a lack of formal participation rights under their respective constitution or due to a lack of activities in the European domain, despite the existence of such rights. ${ }^{16}$ These divergences

13 J. O’Brennan, “Introduction: Deparliamentarization through European Integration?”, in: J. O’Brennan, T. Raunio (eds.), National Parliaments within the Enlarged European Union: From 'Victims' of Integration to Competitive Actors?, Routledge: United Kingdom, 2007, pp. 1-25.

14 European Council, Laeken Declaration of 15 December on the future of the European Union, Annex I to Presidency Conclusions, Laeken Council, 14-15 December 2001, SN 300/1/01.

15 This is called the Early Warning Mechanism and it is laid down in Protocols $\mathrm{No}^{\circ} 1$ and ${ }^{\circ} 2$.

16 Several studies have analyzed the scrutiny activities of national parliaments in the EU. See for example: T. Winzen, "National Parliamentary Control of European Union Affairs: A Cross-National and Longitudinal Comparison”, (2012) 35 West European Politics, pp. 657-672; C. Sprungk, "Ever More or Ever Better Scrutiny? Analysing the Conditions of Effective National Parliamentary Involvement in EU Affairs”, (2010) 14 European Integration online Papers (EIoP); K. Auel, "Democratic Accountability and National Parliaments: Redefining the Impact of Parliamentary Scrutiny in EU Affairs", (2007) 13 European Law Journal, pp. $487-$ 504; W. Wessels, O. Rozenberg, M. Van den Berge, C. Hefftler, V. Kreilinger, L. Ventura, "Democratic Control in the Member States of the European Council and the Euro Zone Summits", (2013) Study for the European Parliament's Committee on Constitutional Affairs; K. Auel, O. Höing, "Scrutiny in Challenging Times - National Parliaments in the Eurozone Crisis”, (2014) Sieps European Policy Analysis. 
in national parliamentary control over EU decision-making have been further exacerbated by the European sovereign debt crisis and the measures adopted as a response thereto by the EU, which divided the Member States into different groups of, for example, 'creditor' and 'debtor' states or signatories and non-signatories to the Fiscal Compact (FC) who were all affected to a different extent.

\subsection{THE ASYMMETRIC IMPACT OF THE CRISIS ON PARLIAMENTARY POWERS AND THE RESULTING IMPLICATIONS FOR REPRESENTATIVE DEMOCRACY IN THE EU}

The European sovereign debt crisis has often been said to have had as a consequence the side-lining and marginalization of both the European Parliament and national parliaments in the EU to the benefit of executive actors such as the European Council, the European Commission and the Eurogroup, ${ }^{17}$ resulting in a democratic deficit that was ostensibly mitigated by the Treaty of Lisbon. In addition, the problem is not just the apparent loss of powers of national parliaments during the crisis, but rather the growing asymmetry of powers between the national parliaments of the Member States. The divergence in parliamentary powers at EU level, though always present, has considerably widened during the Eurozone crisis and has consequently led to a situation whereby some national parliaments are able to use their scrutiny powers and participate in decision-making as usual - or whose scrutiny powers have even been strengthened in EMU matters -, whereas others must adhere to the rules dictated by the European Commission and the ECB and, as a result, barely retain any room for political maneuvers anymore. As a consequence, a considerable power imbalance has manifested itself between the different national parliaments of the Member States, which challenges both the principle of equality between the Member States $^{18}$ and the notion of representative democracy in the EU.

In general terms, the structure of the European Union already poses a problem for representative democracy in that it makes the reconciliation between the notions of representation and responsibility more difficult to ascertain. Representatives of the national citizenries find themselves increasingly unable to act in a responsive manner to those that they have been elected to represent, as they are increasingly constrained by external commitments imposed on them by organizations such as the European Union. ${ }^{19}$ This is even more so the case for those Member States that have adopted the Euro, because the common

17 D. Curtin, “Challenging Executive Dominance in European Democracy", (2014) in 77 The Modern Law Review, pp. 1-32.

18 C. Fasone, "Eurozone, non-Eurozone and 'troubled asymmetries' among national parliaments in the EU. Why and to what extent this is of concern", (2014) 6 Perspectives on Federalism, pp. 3-4.

19 P. Mair, "Representative versus Responsible Government", (2009) MPIfG Working Paper 09/8, pp. 13-15. 
currency with a single monetary policy has intertwined the Eurozone States to a much larger extent than the Member States of the EU as a whole, both economically and politically. Decisions taken by the national governments of the Eurozone Member States do not only affect their national electorate but can also have profound implications for the citizens of the other Member States. This is problematic insofar as many citizens, as a result, can be "affected by decisions that are beyond their control and where they cannot hold the decision-makers to account", ${ }^{20}$ because they do not know who is responsible for adopting the decision. There is an element of detachment between the representatives and those that are meant to be represented.

This problem is exacerbated by the growing asymmetries between the national parliaments during and after the crisis. Not only are the parliaments affected differently with regard to their budgetary powers at the national level, but parliaments that have managed to tighten their grip on their national government - be this for circumstantial reasons, by their own volition or through their national constitutional court - have a much higher degree of influence on the decision-making process at EU level and can thus much better represent the interests of their electorate when compared to those parliaments that have been weakened as a consequence of the crisis. In the worst case scenarios, such a development could lead to a "divided democracy" ${ }^{21}$ with first-class and second-class parliaments, which in turn means that their electorates find themselves in a first-class and second-class democracy respectively.

\subsection{RESEARCH QUESTION AND METHODOLOGY}

The purpose of this book is to analyze and understand the formal power asymmetries that exist between national parliaments in the European Union and to consider the implications of such asymmetries for the state of representative democracy in the EU. The main research question of this book is: how can power asymmetries between national parliaments in the EU be explained and what are the consequences of such asymmetries for EU representative democracy? In a second instance, the book will also look at how, in light of these asymmetries, the role of parliaments in the EU can be (re-)designed in order to ensure the principle of (dual) representative democracy in a post-crisis European Union.

The book is divided into six substantive chapters. Chapter 2 sets out the theoretical framework for the book by discussing the principle of representative democracy, how it

20 J.E. Fossum, "Democracy and Differentiation in Europe”, (2015) 22 Journal of European Public Policy, p. 801.

21 A. Benz, "An Asymmetric Two-Level Game: Parliaments in the Euro Crisis”, in: B. Crum, J.E. Fossum (eds.), Practices of Inter-Parliamentary Coordination in International Politics - The European Union and Beyond, ECPR Press: United Kingdom, 2013, p. 135. 
relates to the concept of accountability and its application within the context of the European Union. These definitions will constitute the underlying concepts for the rest of the book and the analysis therein. It is necessary to point out that the purpose of this chapter is not to provide for a in depth theoretical discussion of the concept of representative democracy; rather this chapter is merely intended to provide for theoretical standards of representative democracy against which practices in the Member States can be judged by taking Article 10(2) of the Treaty on Functioning of the European Union as a starting point.

Chapter 3 looks at the role of the European Parliament and the national parliaments in the European Union under the Treaty of Lisbon and how they have adapted to the European integration process over time. The purpose of this chapter is to give some background information on the role of parliaments in the EU and to recapitulate the literature on parliamentary democracy in the EU and its alleged deficits.

Chapters 4 and 5 analyze the powers of two national parliaments in more detail, namely the German Bundestag and the Irish Dáil Éireann, when it comes to matters concerning the European Union. They examine the formal participation rights of the parliaments that are stipulated in their respective constitutional frameworks in order to exemplify the differences that exist between national parliaments with regard to their influence on EU decision-making.

The German and Irish parliaments have been chosen as the two case studies for this purpose for several reasons. Firstly, they are interesting to contrast because of their different constitutional settings, e.g. their respective systems of election, which in Ireland for example - where a system of single transferable votes in constituencies is in place - leads to constituency issues being treated by parliamentarians as much more salient than EU affairs. This in turn has implications as to how much time is spent on the latter by members of parliaments. Secondly, in light of the analysis that will follow in Chapter 6, the German and Irish parliaments were selected because they both represent a big and a small Member State of the European Union respectively. This aspect will become more pertinent in the analysis of the asymmetries between national parliaments that result from the EU economic governance measures adopted during the crisis. Thirdly, in relation to the latter, the choice for Ireland and Germany was also made because of their different status during the Euro crisis, i.e. a debtor country and a creditor country. While Ireland was the first country to request financial assistance during the crisis, thus becoming the first debtor country, Germany has remained economically stable throughout the crisis and was, together with France, the leading creditor state throughout the negotiations.

While the author recognizes that in this latter aspect the comparison between the German parliament and the Irish parliament yields fewer fundamental insights than one might have hoped for in the beginning of the research, the choice for Ireland and Germany as examples of a debtor and a creditor country was made for specific reasons. One reason 
is the Bundestag's special status during the crisis. As an exception, the Bundestag was not only not marginalized during crisis management but it even managed to gain a tighter grip on the German government following a series of judgments rendered by the Federal Constitutional Court, thereby considerably strengthening its position in matters concerning the EU and specifically the crisis. The Irish parliament, on the other hand, was selected because at the time of the beginning of this book project in 2013, it was the only debtor country that had successfully overcome the crisis and that was able to exit the financial assistance programme at the end of 2013 (even though grantedly it was followed shortly after by Spain and Portugal in the first half of 2014), whereas Cyprus, for example, had only requested financial assistance in 2013 . The choice for Ireland was thus made on the expectation that the research, in light of Ireland's exit of the financial assistance programme in December 2013, would be less likely to be impacted by any further developments in this regard than would be the case for other countries.

Chapter 6 analyzes the impact of the sovereign debt crisis on the powers of national parliaments in a more general manner and it shows that the divergent degrees of parliamentary control over EU matters that were demonstrated in the previous two chapters were only exemplified by the crisis. It examines the several instruments that were adopted by the European Union and its Member States in response to the crisis such as the European Stability Mechanism, the Six-Pack and Two-Pack and the Treaty on Stability, Coordination, and Governance in the EMU and it shows that these instruments have affected national parliamentary powers in an asymmetrical and problematic way.

Chapter 7 analyzes the consequences of the findings of the previous chapters for democracy in the EU and makes suggestions on how these consequences can be remedied by first illustrating the meaning of representative democracy. Then, different ideas of how the European Parliament and the national parliaments could be (re-)designed in light of the power asymmetries between national parliaments that have been analyzed in the previous chapters are presented, and evaluated on the basis of the meaning of representative democracy that was asserted at the beginning of this book.

Conclusions are drawn and suggestions are then subsequently made in Chapter 8.

The research carried out in this book is of a legal nature and thus to a large extent follows a traditional legal approach, under which the relevant law - i.e. EU and national constitutional law - and legal literature is studied. In addition, as constitutional law and parliamentary studies are very closely linked to political science as well, the literature review sections of this book also include relevant contributions made by political science scholars on this topic. To a limited extent, the book also attempts to consider the practical relevance of the legal provisions analyzed in Chapters 4 and 5 by broadly looking at how often some of the procedures were effectuated by the respective parliaments. To this end, the databases on the websites of the German Bundestag and the Irish Dáil were used to test the level of activities of both parliaments. However, as this book is a legal project in nature, the focus 
of the book is on the formal procedures by which parliamentary scrutiny is organized and on the formal differences that exist in national parliamentary powers in EU affairs. It does not explore in depth the practical use of such procedures by parliaments. Such an analysis would fall outside the scope of this book, even though its importance for the topic is not disputed. The practical use of formal rights by parliaments constitutes an interesting and salient question, which has served and should serve as a basis for further research by other scholars in the field. 


\section{REPRESENTATIVE DEMOCRACY}

\subsection{INTRODUCTION}

Most modern political systems in the Western world have adopted a model of representative democracy, even though the way the systems are designed can differ from one country to another. One example of how such systems can differ is the contrast between a parliamentary system of government and a presidential system of government, whereby the difference lies in whether or not the head of the executive is dependent on the support of the parliamentary majority. Other differences can also be found in the way the electoral system is designed, with the options ranging from proportional representation (e.g., in the Netherlands) to majoritarian systems (the United Kingdom) or mixed systems (Germany). What all representative democracies have in common, however, is the regular election of representatives who will take decisions on behalf of the citizens for a certain period of time until the next elections are due to take place. Here, representative democracy differs from direct democracy, where citizens govern themselves directly without a representative assembly acting as an intermediate. It moreover constitutes the premise on which the European Union is founded (Article 10(2) TEU).

This chapter has as its objective the discussion of the concept of representative democracy in order to establish a theoretical framework that will guide the research that is presented in this book. The purpose of this chapter is not to provide for an exhaustive theoretical discussion of the concept of representative democracy; rather this chapter is merely intended to provide for theoretical standards of representative democracy against which practices in the Member States can be judged. For that reason it will remain relatively brief. It will first describe what is meant by representative democracy and by the concept of 'representation' in particular. In this regard, the principal-agent theory - a theory that is generally better known in the economic field - will be used in order to illustrate the relationship between citizens, parliament, and government, which together forms a socalled chain of delegation: the citizens delegate part of their decision-making authority to parliament, which in turn delegates some of its authority to the executive. In reverse, this means that the executive is accountable to parliament when acting in the capacity of the former's agent, which in turn is accountable to the citizens. As part of this arrangement, the parliament is thus both principal and agent in one - it acts as the principal vis- $\dot{a}$-vis the government and as the agent vis-à-vis the citizens. As a result, accountability in representative democracies is organized, for one, between the citizens and the parliament (usually through regular elections) and, second, between the parliament and the executive (usually through parliamentary procedures of scrutiny and accountability). 
The concept of accountability, as is defined in section 2.3.1.2 of this chapter, is of special importance with regard to the role of national parliaments in the EU. Because national parliaments, as a general rule, do not directly participate in the EU decision-making process - even though a case could be made for the Early Warning Mechanism to constitute direct participation therein - their influence on EU decision-making is, to a large extent, dependent on their control over the executive negotiating in Brussels, who is in turn accountable to the national parliament for its actions at EU level. This latter relationship is also emphasized by the current Treaty framework that is found in Article 10(2) TEU. An effective design that puts the concept of accountability into effect between the national governments acting at EU level and their national parliaments at home is thus indispensable for the representation of citizens by parliament. If the latter has no control over what the executive does at EU level, it will also find itself unable to comprehensively represent any of its citizens' interests in the European Union.

However, representation of the citizens' interests in the EU is, in fact, dependent on a few more factors than just effective influence over the own executive (this will be shown in Chapter 6) and it also includes the notion of responsibility, which means that the representatives must also have the capacity to govern effectively. This is increasingly difficult for national parliaments and governments in an intertwined legal order such as the European Union. This problem of reconciling responsiveness vis-à-vis the citizens with the notion of responsibility will be further discussed in Sections 2.3.1 and 2.3.2, before Section 2.4 then evaluates the general problems of representative democracy in the European Union. This part will be of special importance for Chapters 6 and 7, which will shed light on the exacerbation of these issues, caused inter alia by the Euro crisis and the responses in relation thereto.

\subsection{THE CONCEPT OF REPRESENTATIVE DEMOCRACY}

In general, representative democracy simply means that those who govern (the representatives) are elected by those who are governed (the represented) at regular intervals, as opposed to the latter governing themselves as would be the case in a direct democracy. ${ }^{1}$ The represented are free to express their own opinions and political wishes without being controlled by the representatives, while the latter retain a certain degree of independence from the former's wishes when taking decisions, which in turn are subject to public debates. ${ }^{2}$ Such a system of democracy ensures, for one, political equality in that one person gets one vote irrespective of their age (as long as they are eligible to vote), gender or socio-economic

1 B. Manin, The Principles of Representative Government, Cambridge University Press: United Kingdom, 1997, p. 6.

2 Ibid. 
status. It also makes sure that visions and ideas are put into words, as the discourses thereon constitute the basis on which political parties ask for their voters' support as well as the basis for the latter to hold the representatives to account. This has the added effect that a sub-set of individual interests must be turned into categorical societal interests in order for this process to work. ${ }^{3}$

\subsection{REPRESENTATION: RESPONSIVENESS VS. RESPONSIBILITY}

Representation comprises two components: responsiveness and responsibility. Hannah Pitkins defines representation as "acting in the interest of the represented, in a manner responsive to them." 4 This means that, on the one hand, the representative must be able to act independently according to his own judgment and with a certain degree of discretion. On the other hand, the represented must be able to judge such actions insofar as an (good) explanation must be given by the representative whenever their actions conflict with the interests of the represented (even though such a conflict should not take place in ideal terms). ${ }^{5}$ According to Pitkin, it is not always necessary for the represented to articulate their wishes; it is only important that they are able to do so and, if they have done so, that the representative will act in accordance with such wishes unless there is good reason not to do so. This same principle applies in the context of a representative government. ${ }^{6}$

\subsubsection{Responsiveness}

It is through their government that people act and it is to them that a government must be responsive. This means that a mechanism must be established so as to ensure that the represented are able to express their wishes and that the government will, in general, respond thereto. ${ }^{7}$ Here, the emphasis lies more on the existence of a "constant condition of responsiveness" as opposed to a "constant activity of responding", meaning that a representative government must be responsive to popular wishes as and when they exist - it does not need to constantly respond to wishes in order for it to be regarded as representative. It is only important that the government does not refuse to act in accordance with the people's wishes without good reason or in a systematic manner and that it is ensured,

3 S. Piattoni, "The European Union: Legitimating Values, Democratic Principles and Institutional Architectures”, in: S. Piattoni (eds.), The European Union - Democratic Principles and Institutional Architectures in Times of Crisis, Oxford University Press: United Kingdom, 2015, pp. 21-22.

4 H. Pitkin, The Concept of Representation, University of California Press: United States, 1967, p. 209.

5 Ibid.

$6 \quad$ Ibid., p. 232.

$7 \quad$ Ibid. 
through institutional arrangements, ${ }^{8}$ that the represented can initiate government actions if they want to as well as cast judgment thereupon. ${ }^{9}$ Overall, political representation "requires only potential responsiveness", ${ }^{10}$ which must be embedded in long-term systematic arrangements. ${ }^{11}$ According to Pitkin, there are few basic prerequisites needed for such arrangements in order for them to constitute a representative government; they must, however, in any case include regular genuine and free elections as well as "some sort of collegiate representative body in more than advisory capacity", i.e., some sort of parliamentary assembly. Whether the system is headed by a Prime Minister or a President, and whether the government is elected by proportional representation or a majoritarian election system is not relevant in this regard. ${ }^{12}$

\subsubsection{Principal-agent theory in democratic systems}

This relationship between those represented and their representatives can be well explained in terms of a principal-agent relationship, in which a chain of delegation exists. Those who are authorized to make political decisions (i.e., the represented or the principals) designate others (the representatives or the agents) to do so in their place, subject to certain conditions. ${ }^{13}$ In a democratic system, the ultimate decision-making power belongs to the citizens. They act as the principal by delegating their power to their elected representatives, i.e., parliament. Parliament in turn delegates some of its powers to the executive and, more specifically, to the head of government. He or she then further delegates some of his or her power to the ministerial officers.

This idea of a parliamentary chain of delegation also relates to a prevailing concept in German constitutional law that is known as the chain of legitimation. ${ }^{14}$ The chain of legitimation is based on the idea that every act of the State must be based on the will of the people. Therefore, democratic legitimation only exists where there is an uninterrupted chain of legitimacy between the citizens and those who govern them. ${ }^{15}$ All government

$8 \quad$ Ibid., pp. 232-233.

$9 \quad$ Ibid., p. 232.

10 Ibid., p. 233.

11 Ibid., p. 234.

12 Ibid., p. 234-235.

13 W. Müller, T. Bergman, K. Strom, "Parliamentary Democracy: Promise and Problems”, in K. Strom, W. Müller, T. Bergman (eds.), Delegation and Accountability in Parliamentary Democracies, Oxford University Press: New York, USA, 2006, p. 19; see also T. Winzen, "National Parliamentary Control of European Union Affairs: A Cross-national and Longitudinal Comparison”, (2012) 35 West European Politics, p. 659; G. Abels, "Parlamentarische Kontrolle im Mehrebenensystem der EU - ein unmögliches Unterfangen?", in B. Eberbach-Born, S. Kropp, A. Stuchlik, W. Zeh (eds.), Parlamentarische Kontrolle und Europäische Union, Nomos: Baden-Baden, 2013, p. 82.

14 E. W. Böckenförde, Staat, Verfassung, Demokratie: Studien zur Verfassungstheorie und zum Verfassungsrecht, Suhrkamp: Frankfurt am Main, 1991, p. 302.

15 Ibid., A. von Bogdandy, "Globalization and Europe: How to Square Democracy, Globalization and International Law”, (2004) 15 The European Journal of International Law; p. 902; S. Siefken, "Konfigurationen 
officials must be appointed by the citizens - either directly or indirectly - and it must be possible to trace back each of their appointments to the will of the citizens. It is only when this chain is uninterrupted that the institutional system will be regarded as legitimate. ${ }^{16}$ Applied to the chain of delegation, this means that a delegation of power is only legitimate if it can be traced back to the main principal without any form of interruption. This is also the idea behind the concept of input legitimacy. ${ }^{17}$ Characterized by the expression of 'government by the people', it implies that "collectively binding decision should originate from the authentic expression of the preferences of the constituency in question." ${ }^{18}$ Political choices are only legitimate if and because they reflect the will of the people, who are bound by them. ${ }^{19}$ Thus, compliance with such decisions can be expected because they are "are self-determined, rather than imposed by an exogenous will." 20

The delegation of powers can be done for either competence or efficiency reasons. One condition for it is that the principal retains the power to de-authorize and replace the agent when the latter deviates from or exceeds the powers that were delegated to him. ${ }^{21}$ This already implies that, even though the agent is supposed to realize the principal's interests, the agent's actions do not necessarily always correspond with what the principal expected of him; this is called agency loss. Lupia describes agency loss as "the difference between

parlamentarischer Kontrolle: Ein Konzept für die vergleichende Analyse”, in B. Eberbach-Born, S. Kropp, A. Stuchlik, W. Zeh (eds.), Parlamentarische Kontrolle und Europäische Union, Nomos: Baden-Baden, 2013, p. 55.

16 Böckenförde, supra note 14 , p. 302

17 See for a general discussion on democratic legitimacy in the EU for example: J.H.H. Weiler, U. Haltern, F. Mayer, "European Democracy and its Critique - Five uneasy Pieces", (1995) European University Institute Working Paper RSCNo. 95/11; F.W. Scharpf, "Interdependence and Democratic Legitimation", (1998) MPIfG Working Paper 98/2; G. Majone, “Europe’s 'Democratic Deficit’: The Question of Standards”, (1998) 4 European Law Journal, pp. 5-28; F.W. Scharpf, Governing in Europe: Effective and Democratic?, Oxford University Press: Oxford, 1999; C. Lord, "Democracy and Democratization in the European Union", in S. Bromley (ed.), Governing the European Union, SAGE Publications: London, 2001, pp. 165-190; A. Moravcsik, "In Defence of the 'Democratic Deficit': Reassessing Legitimacy in the European Union”, (2002) 40 Journal of Common Market Studies, pp. 603-624; A. Schaefer, "Die Demokratische Grenze OutputOrientierter Legitimation", (2006) 29 Integration, pp. 187-200; A. Menon, S. Weatherill, "Democratic Politics in a Globalizing World: Supranationalism and Legitimacy in the European Union”, (2007) LSE, Law, Society and Economy Working Papers 13/2007; R. Holzhacker, "Democratic Legitimacy and the European Union", (2007) 29 European Integration, pp. 257-269; R. Bellamy, “Democracy Without Democracy? Can the EU's Democratic 'Outputs' be Separated from the Democratic 'Inputs' Provided by Competitive Parties and Majority Rule?', (2010) 17 Journal of European Public Policy, pp. 2-19; D. Gaus, “Two Kinds of Democratic Legitimacy for the EU? Input- and Output-Oriented Legitimacy as a Case of Conceptual Misformation”, (2010) Paper presented at the conference 'Democracy as Idea and Practice', Oslo 14-15 January 2010; W. Sadurski, "Democratic Legitimacy of the European Union: A Diagnosis and Some Modest Proposals", Sydney Law School Legal Studies Research Paper No. 13/29.

18 Scharpf (1998), supra note 17, p. 3.

19 Scharpf (1999), supra note 17, p. 6.

20 Scharpf (1998), supra note 17, p. 3.

21 C. Sprungk, "Ever More or Ever Better Scrutiny? Analysing the Conditions of Effective National Parliamentary Involvement in EU Affairs", (2010) 14 European Integration online Papers (EIoP), p. 6. 
the actual consequence of delegation and what the consequence would have been had the agent been 'perfect'. ."22 However, such a case of a 'perfect' agent hardly occurs. ${ }^{23}$ According to the principal-agent theory, any delegation of powers entails two main risks for the principal; one is the divergence of interests and the other is the provision of asymmetric information. ${ }^{24}$

Divergence of interest describes a situation where the agent and the principal both pursue different policy objectives. ${ }^{25}$ As a consequence, the agent may either fail to act in the principal's best interests (shirking) or may even act against those interests (sabotage). ${ }^{26}$ Asymmetric information relates to the situation in which different information has been given to the principal and the agent respectively. Typically, this occurs because the agent discloses more information than the principal. Such information can concern two issues. Firstly, it can concern both the ability and willingness of the agent to perform in a way as expected of him by the principal as well as the circumstances for such a performance (hidden information). Where the principal does not disclose such hidden information, it may result in an adverse selection of the agent, i.e., the appointment of an unsuitable agent who is either unwilling or unable to fulfill the interests of the principal. ${ }^{27}$ Secondly, the asymmetry of information can also concern the agent's actions when the principal is not able to readily determine the activities of the agent (hidden action) ${ }^{28}$ Where he lacks such information, the agent "never benefits from choosing any action other than his own ideal point." 29 Thus, if the principal cannot keep his agent honest and diligent, this may lead to the agent acting in accordance with his own interest only (moral hazard). ${ }^{30}$

Such a danger of agency loss, though present in a national context, is even more so present in the European context. ${ }^{31}$ The problem of asymmetric information and moral hazard is reinforced by the system of multi-level governance in the European Union. While the government is a key actor in the EU decision-making process, national parliaments are not directly represented by an institution at the European level. The ministers in the Council and the Heads of State or Government in the European Council are acting, to a large extent, behind closed doors and unobserved by the public. As a result, the government

22 A. Lupia, "Delegation and its Perils", in K. Strom, W. Müller, T. Bergman (eds.), Delegation and Accountability in Parliamentary Democracies, Oxford University Press: New York, USA, 2006, p. 35.

23 Ibid.

24 Strom, Müller, Bergman, supra note 13, p. 23.

25 Ibid.

26 See also: J. Brehm, S. Gates, Working, Shirking and Sabotage-Bureaucratic Response to a Democratic Public, University of Michigan Press: Michigan, USA, 1999.

27 Lupia, supra note 22, p. 43.

28 K. Auel, "Democratic Accountability and National Parliaments: Redefining the Impact of Parliamentary Scrutiny in EU Affairs", (2007) 13 European Law Journal, p. 496; Brehm, Gates, supra note 26, p. 25.

29 Lupia, supra note 22, p. 42.

30 Strom, Müller, Bergman, supra note 13, p. 23.

31 Sprungk, supra note 21, p. 8. 
enjoys privileged access to information that is not available to parliaments or to the public. This especially relates to the problem of hidden action. Because the government acts in an environment that "generally lacks transparency since privacy and secrecy are considered conducive to negotiations", ${ }^{32}$ it is difficult for parliament to determine whether or not the government is acting in accordance with its wishes. In order to limit the risks of agency loss and in order to ensure that the principal retains the power to de-authorize and replace the agent, every chain of delegation is mirrored by a corresponding chain of accountability. This chain of accountability runs in the reverse direction and it guarantees that each agent is accountable towards their direct principal. ${ }^{33}$

\subsubsection{The concept of accountability}

There exists no precise definition of the concept of accountability. Different people associate different meanings with the term. ${ }^{34}$ In a more general sense, however, it can be said that accountability concerns the

relationship between an actor and a forum, in which the actor has an obligation to explain and to justify his or her conduct, the forum can pose questions and pass judgment, and the actor may face consequences. ${ }^{35}$

For Western democratic systems, political accountability has become an integral part that cannot be dispensed with. Its purpose is to prevent the abuse of political power and to guarantee that an uncorrupt system stays uncorrupt. ${ }^{36}$ It also plays a role in ensuring that the actions of the government correspond to the public interest, ${ }^{37}$ or put differently: that delegation acts are effective in the sense that they fulfill the principals' interests. ${ }^{38}$ In the chain of accountability, this means that the executive acts according to parliament's wishes, which in turn ensures the interests of its citizens.

32 T. Winzen, "European Integration and National Parliamentary Oversight Institutions", (2013) 14 European Union Politics, p. 298.

33 Strom, Müller, Bergman, supra note 13, p. 20.

34 R. Mulgan, “'Accountability’: An Ever-Expanding Concept?”, (2000) 78 Public Administration, p. 555; M. Bovens, "New Forms of Accountability and EU-Governance", (2007) 5 Comparative European Politics, p. 105.

35 Bovens, supra note 34, p. 107; see also: A. Schedler, "Conceptualizing Accountability", in A. Schedler, L. Diamond, M. Plattner (eds.), The Self-Restraining State, Lyenne Rienne Publishers: Colorado, USA, 1999, p. 556; P. Schmitter, "Political Accountability in 'Real-Existing' Democracies: Meaning and Mechanisms", (2007), available at: <www.eui.eu/Documents/DepartmentsCentres/SPS/Profiles/Schmitter/PCSPoliticalAccountabilityJan07.pdf> (last retrieved on 10 September 2014), p. 4.

36 D. Oliver, "Executive Accountability: A Key Concept”, in L. Verhey, P. Kiiver, S. Loeffen (eds.), Political Accountability and European Integration, Europa Law Publishing: Groningen, 2009, p. 14; Schedler, supra note 35, p. 14 .

37 Oliver, supra note 36, p. 15.

38 Lupia, supra note 22, p. 35. 
Political accountability involves two principal elements: (1) there is an obligation to inform about and justify the exercise of political powers and (2) the exercise of those powers is subject to the threat of sanctions. In a democratic system, in which the government is accountable to parliament, this translates into the power of parliament to make a judgment on the exercise of powers by the government and, where necessary, to sanction it for its actions (holding to account). In order to be able to evaluate the government's conduct, the latter must be transparent, which means that the government is obliged to inform parliament of its activities and justify them when necessary (calling into account). ${ }^{39}$ In its core sense, accountability affects the relationship between "the citizens and the holders of public office and, within the ranks of office holders, between elected politicians and bureaucrats." ${ }^{40}$ It concerns the question of how voters can make their elected representatives accountable for their policy choices and how they can sanction the legislators for policies that do not correspond to their will; it also concerns the question of how the legislators can make the executive answer for their actions and how they can sanction them for their mistakes or omissions.

Thus, accountability involves the delegation of certain tasks to another institution under the threat of potential sanction for misconduct. This can be understood in two different ways. Accountability can either be a process of control, in which the agent is accountable to the principal to the extent that the latter can influence his actions. Or it can be a type of outcome, where the agent is accountable to the principal if he acts in the latter's interests. ${ }^{41}$ For the purposes of this book, accountability is understood as a process of control, in which the principal (national parliaments) must be able to control the agent's (the national governments acting at EU level) actions. The main instruments for national parliaments to do so are their (1) right to demand information, (2) power to influence the government's position in EU negotiations and (3) power to sanction the government for deviating from its prescribed position.

\subsubsection{Responsibility}

If responsiveness is understood as the government party acting as the representative of the citizens according to Pitkin's definition explained above, then responsibility means the governing party's role to "supply office holders and to govern", ${ }^{42}$ i.e., to take decisions

39 L. Verhey, "Political Accountability: A Useful Concept in EU Inter-Institutional Relations?", in L. Verhey, P. Kiiver, S. Loeffen (eds.), Political Accountability and European Integration, Europa Law Publishing: Groningen, 2009, p. 63.

40 Mulgan, supra note 36, p. 556.

41 Lupia, supra note 22, p. 35.

42 B. Laffan, "Testing Times: The Growing Primacy of Responsibility in the Euro Area", (2014) 37 West European Politics, p. 274. 
on behalf of the represented. It has, however, become increasingly difficult for parties to reconcile these two roles of responsiveness and responsibility. Mair identifies two underlying reasons for this. The first one is difficulties to recognize and to aggregate citizens' preferences in a way as to be able to represent them accordingly. The second one is the fact that for parties, once they have come into office, 'governing' does not only mean putting certain policies into effect; it also means that when doing so they are obliged to adhere to external constraints and the commitments that have been imposed on them by external organizations such as the European Union. ${ }^{43}$

This relates to the democratic output of a system, ${ }^{44}$ and is reflected by the term 'government for the people'. Decisions by the representative must "achieve a high degree of effectiveness in achieving the goals, and avoiding the dangers, that citizens collectively care about", or else "democracy would be an empty ritual." ${ }^{\prime 5}$ It implies that "collectively binding decisions should serve the common interest of the constituency." ${ }^{46}$ Such decisions are complied with because they solve problems that the members of the constituency would not be able to solve on an individual basis. ${ }^{47}$ In order to be legitimate from an output-oriented perspective, political institutions must achieve favourable outcomes. Here, effectiveness in itself can be a source of legitimization. ${ }^{48}$ According to Scharpf, both input-oriented authenticity and output-oriented effectiveness are crucial for the democratic legitimacy of a system. ${ }^{49}$ Thus, a system is only as legitimate insofar as its institutionalized mechanisms are able to channel its citizens' preferences into responsive and responsive policy outcomes (as opposed to a situation whereby policy outcomes and citizens' preferences are purely "matching by happy coincidence")..$^{50}$

A national government loses its ability to act effectively responsible, i.e., its ability to act unilaterally and take unilateral decisions on a certain policy area, when it shares responsibilities for such policies with the governments of other Member States of the same organization. ${ }^{51}$ The consequence of this shared responsibility is that it hinders the national

43 P. Mair, "Representative versus Responsible Government”, (2009) MPIfG Working Paper 09/8, pp. 13-15.

44 See also: G. Majone, “Europe's 'Democratic Deficit': The Question of Standards”, (1998) 4 European Law Journal, pp. 5-28; A. Menon, S. Weatherill, "Democratic Politics in a Globalizing World: Supranationalism and Legitimacy in the European Union”, (2007) LSE, Law, Society and Economy Working Papers 13/2007; A. Moravcsik, "In Defence of the 'Democratic Deficit': Reassessing Legitimacy in the European Union", (2002) 40 Journal of Common Market Studies, pp. 603-624.

45 F.W. Scharpf, "Economic Integration, Democracy and the Welfare State", (1997) 4 Journal of European Public Policy, p. 19.

46 Scharpf (1998), supra note 17, p. 3.

47 Ibid.

48 Menon, Weatherill, supra note 46, p. 4.

49 Scharpf (1998), supra note 17, p. 19.

50 A. Follesdal, S. Hix, "Why There Is a Democratic Deficit in the EU: A Response to Majone and Moravcsik", (2006) 44 Journal of Common Market Studies, pp. 556.

51 R. Rose, "Responsible Party Government in a World of Interdependence", (2014) 37 West European Politics, p. 256. 
electorate from holding the government accountable for taking actions that diverge from its preferences. ${ }^{52}$ This is because national governments are no longer only responsive to their voters, but they must also take into account the preferences of the other Member States in order to reach a compromise. Put differently, the electorate is no longer the only principal according to whose wishes government should act, but rather there is an array of different principals whose different principles and rules must be followed and considered. ${ }^{53}$ This issue will be discussed in more detail with regard to the EU in the following section.

\subsection{REPRESENTATIVE DEMOCRACY IN THE EU}

Article 10(1) of the TEU states that "the functioning of the Union shall be founded on representative democracy", without defining this concept any further. In Article 10(2), the Treaty only clarifies:

Citizens are directly represented at Union level in the European Parliament. Member States are represented in the European Council by their Heads of State or Government and in the Council by their governments, themselves democratically accountable either to their national Parliaments, or to their citizens.

It also states that every citizen "shall have the right to participate in the democratic life of the Union. Decisions shall be taken as openly and as closely as possible to the citizen" (Article 10(3) TEU). This, together with the provisions on the EP elections (Article 14 TEU) seems to be as far as the Treaty goes in explaining how it envisages representative democracy to be implemented in the EU.

As was stated above, representative democracy is, simply put, the governing of a political entity by elected representatives as opposed to self-governing by the former themselves. Representative democracy is a difficult notion to apply in the context of the European Union insofar as there is no single body of citizens which is to be represented. Nor is there a single body of government by which they are represented. In national systems of representative government, citizens - as the governed - do not only express their wishes or policy preferences, but they also delegate authority to their elected representatives to legislate on their behalf as an expression of sovereignty. This normally presupposes the

52 Ibid.

53 Mair, supra note 45, p. 12. 
existence of a single people, a demos, which is capable of doing so. ${ }^{54}$ Such a single demos does not, however, exist within the context of the EU. Rather, there are several demoi in the different Member States, which can arguably only delegate their authority to their own (national) representatives ${ }^{55}$ - a theory that was also put forward by the German Federal Constitutional Court, which in the early 1990s, already emphasized the role of the German Bundestag in the European integration process. Because there is no single European demos in the EU, the German Court claims that the domestic routes of legitimacy - most notably national parliaments - remain the main source of democratic legitimacy for the Union.

The German Court repeated this argument in its Lisbon judgment in 2009, where it arrived at the conclusion that the European Union, as it is designed under the Treaty of Lisbon, does not correspond to the level of democratic legitimacy of a nation-state. ${ }^{56}$ Rather the German Federal Constitutional Court argued that the democratic legitimacy of the Union ultimately derives from the national parliaments and governments, and that it is merely "complemented and sustained" by the directly elected $\mathrm{EP},{ }^{57}$ which it finds to remain a "representation of the peoples linked to each other by the treaties albeit now with special emphasis on citizenship of the Union. ${ }^{58}$ The German Court left little doubt that, in its view, the European Parliament is not a fully-fledged parliament as it is does not conform to the principle of equal elections by all citizens, whereby all votes have the same value (one man, one vote). In combination with the lack of a clear distinction between the government and the opposition, the German Court has denied the ability of the EP to uniformly represent the will of the (European) people. ${ }^{59}$ It states that:

Democracy first and foremost lives on, and in, a viable public opinion that concentrates on central acts of determination of political direction and the periodic allocation of highest-ranking political offices in the competition of government and opposition. Only this public opinion shows the alternatives for elections and other votes and continually calls them to mind also in decisions relating to individual issues in order that they may remain continuously present and effective in the political opinion-formation of the people via the parties, which are open to participation for all citizens, and in the public information area. To this extent, Article 38 and Article 20.1 and 20.2 of the Basic Law also protect the connection between political decisions on facts and the will of the

54 S. Piattoni, "Is the EU a Representative Democracy?", in: F. Fabbrini, E. Hirsch Ballin, H. Somsen (eds.), What Form of Government for the European Union and the Eurozone?, Hart Publishing: United Kingdom, 2015, p. 135.

55 Ibid.

56 BVerfG, Judgment of 30 June 2009, 2BvE 2/08, para. 276.

57 Ibid., para. 277.

58 Ibid., para. 279.

59 Ibid., para. 280. 
majority constituted by elections, and the resulting dualism between government and opposition in a system of a multiplicity of competing parties and of observing and controlling formation of public opinion. ${ }^{60}$

All of this is arguably not existent at the EU level. But even if a government were to be formed at the EU level, with a genuine opposition as its competition, the EP would fall short of the German Court's criteria of what constitutes a genuine representative assembly in a representative democracy. Because of the way in which the EP elections are designed, it is not guaranteed that a majority decision taken in the EP will necessarily reflect the wishes of the majority of the Union citizens. Instead, due to the principle of degressive proportionality - according to which the EP is elected - the possibility would exist that "a minority of citizens with numbers based on the existing ratio of representation by a majority of Members of the European Parliament would thus govern against the political will of a majority opposition of Union citizens which would not be reflected as a majority in numbers." ${ }^{\prime 1}$

The Czech Constitutional Court, on the other hand, took a different stance on the same issue. It stated in its Lisbon judgment of 2009 that "the democratic process on the Union and domestic levels mutually supplement and are dependent on each other." ${ }^{62}$ By way of contrast to the German Court, the Czech Court rejected the idea that representative democracy can only exist at nation-state level, and stated that it is "one of the standard principles for the organization of larger entities, both inter-state and non-state organizations", and just because it exists at the Union level, this does not preclude its existence at national level as well. ${ }^{63}$ Rather, democratic legitimacy for decisions adopted is derived from a combination of structures on both the EU and domestic level respectively. ${ }^{64}$

Such a double structure exists because there are two types of subjectivities in the EU. ${ }^{65}$ On the one hand, there are the national citizenries of the 28 different Member States, which are represented by their government and parliament at home and, through them, in the Council and European Council at EU level. Concomitantly, EU citizens are also represented by the directly elected European Parliament as the representative body at EU level. This dispersion of both levels of representative government - those who govern and those who are governed - makes representative democracy in the EU a rather complicated matter. There exists a lack of a clear differentiation between the representation of citizens as EU citizens and the representation of citizens as citizens of the different Member States, as

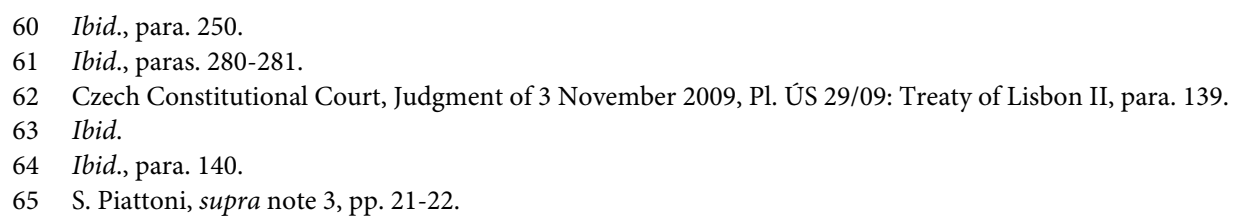


well as the link between the two. ${ }^{66}$ The individual members of the Council and European Council represent the citizens of their respective Member State, but at the same time the institutions as a whole are European institutions furthering European interests. National governments in the EU, and especially in the Eurozone, are not only responsible and accountable to their own citizens via the national parliament, but they also have a commitment towards the governments of the other Member States.

66 R. Bellamy, D. Castiglione, "Three Models of Democracy, Political Community and Representation in the EU”, (2013) 20 Journal of European Public Policy, p. 206. 



\section{Parliaments in the European Union}

\subsection{INTRODUCTION}

The introductory chapter to this research explained that as a result of the deepening of the European integration process and due to a shift in decision-making powers, there was a gradual erosion of national parliamentary powers. In order to understand the power asymmetries between national parliament and how such power asymmetries impact the concept of representative democracy in the EU, it is consequently necessary to begin the research by analyzing the role of parliaments in the EU legal order. Since the latter is inextricably linked to the development of the European Union as a whole, this chapter will review the historical development of the European Parliament and the national parliaments in the EU by starting in the 1950s following the introduction of the European Coal and Steel Community and tracing its evolution up until the Treaty of Lisbon. It will show that as a consequence of changes to the very nature of the EU, the role of the European Parliament and the role of national parliaments have changed as well.

For as long as EU actions were perceived as serving a common interest and did not touch upon politically sensitive policy areas, no legitimation at EC level through the European Parliament was required. ${ }^{1}$ The fact that national parliaments agreed to treaty amendments at EC level was sufficient legitimation in this regard. However, the problem was that national policy-making was becoming increasingly obstructed by the existence of EU policies, leading to a situation whereby the national democratic processes of the Member States were becoming increasingly constrained; while at EU level, the existence of democratic legitimacy was increasingly contested. ${ }^{2}$ The furthering of the EU integration process has increased executive power and this in turn has led to the loss of national parliamentary control. This loss of national parliamentary control could not be duly compensated by the existence of the European Parliament, as it lacks the powers that national parliaments possess and therefore it could not be seen as a valid substitute. ${ }^{3}$ Against the backdrop of this development, national parliaments are often considered to be the losers

1 F.W. Scharpf, "Economic Integration, Democracy and the Welfare State", (1997) 4 Journal of European Public Policy, pp. 21-22.

2 Ibid., p. 29.

3 Jurgens especially sees a problem in the fact that the EP has no oversight powers over the Council, which can no longer be controlled by the respective national parliaments. See: E. Jurgens, "Federal Option for European Communities or a Permanent Democracy Deficit?", in C. Flinterman, A.W. Heringa, L. Waddington (eds.), The Evolving Role of Parliaments in Europe, Maklu Uitgevers: Antwerp, 1995, pp. 84,86 . 
of integration', ${ }^{4}$ and European integration has been perceived as a threat to their legislative powers. ${ }^{5}$ The shift of competences to the EU level in areas which were previously within the powers of the national legislature and the changing decision-making structure at the EU level, led to the weakening of national parliaments, which did not immediately adapt to these changes.

Four different phases of the debate on democracy in the EU can be identified. The first phase took place between the 1950s and 1970s and is characterized by the idea that the EU was merely an international organization. The second phase came in the 1980s, when the EC began to acquire more competences, thereby shifting it towards a supranational organization. This period is also characterized by the introduction of qualified majority voting (QMV) in the Council of Ministers. The third phase then began in the 1990s following the entry into force of the Treaty of Maastricht, with which the EU became a "genuine public political power" with more stringent requirements in relation to its democratic legitimacy. ${ }^{6}$ It was also in the 1990s that the debate turned away from focusing on output legitimacy and efficiency and started to focus on input legitimacy and the EU's democratic processes. This ultimately led to the Laeken Declaration and the signing of the Treaty of Lisbon, which had the effect of enhancing the EU's democratic legitimacy by strengthening the role of the European Parliament. It may now be the case that a fourth phase is emerging as a result of the financial crisis. The measures that have been adopted as a response to the latter have resulted in the re-emergence of intergovernmentalism and certain steps have undermined the European Parliament's decision-making authority, thus initiating a fresh debate on the legitimacy and the manner of the EU decision-making process.

The first part of this chapter will give a brief introduction into the role of national parliaments and the European Parliament in the EU respectively. The second part will review the development of the EU from the 1950s onwards, the discussions on its democratic credentials and how this has affected the perception, role and powers of the European Parliament and of national parliaments respectively. The third part will describe the current role of national parliaments in the EU as per EU primary law. The fourth part will look at the legislative, budgetary and supervisory powers of the EP under the Treaty of Lisbon, before the chapter will make some brief observations on the role of parliaments in the EU.

4 A. Maurer, W. Wessels (eds.), National Parliaments on Their Ways to Europe: Losers or Latecomers?, Nomos: Baden-Baden, 2001.

5 K. Auel, O. Höing, "Parliaments in the Euro Crisis: Can the Losers of Integration Still Fight Back?", (2014) 52 Journal of Common Market Studies, p. 1184.

6 M. Nettesheim, "Developing a Theory of Democracy for the European Union", (2005) 23 Berkeley Journal of International Law, p. 361. 


\subsection{The European Parliament and national parliaments}

The European Parliament is the representative organ of the European Union at EU level and one of the seven EU institutions (Article 13(1) TEU). It is arguably "the world's most far-reaching experiment in transnational democracy, where international diplomacy is replaced - or at least complemented by - transnational democracy." ${ }^{7}$ The EP is often presented as the open democratic face of the EU, which is supposed to uphold the EU's democratic legitimacy. ${ }^{8}$ According to Article 14(2) TEU, the European Parliament is composed of the representatives of the Union's citizens. ${ }^{9}$ Their number does not exceed 751 members of parliament (MEPs), which includes the EP President, who is elected by the Parliament from among its members (Article 14(4) TEU). The MEPs are elected for a term of five years by direct universal suffrage (Article 14(3) TEU) in their respective Member States. The system is one of degressive proportionality whereby the minimum number of MEPs per Member State is six and the maximum number is 96 (Article 14(2) TEU). MEPs are organized in political groups, as opposed to national groups, in the EP.

The national parliaments are the 28 (soon to be 27) individual parliamentary assemblies of the different Member States of the European Union. They are generally considered to be the representative bodies and legitimizing institutions at the national level, ${ }^{10}$ and they serve as the intermediate between the government representatives in the Council and the Heads of State or Government in the European Council at EU level and to their citizens at home (Article 10(2) TEU). This indirect participation of national parliaments at EU level - through scrutinizing the government representatives in the Council and in the European Council - is the more traditional role that has been accorded to national parliaments in the EU. It relies on the dual representation structure that was mentioned above, in which the European Parliament constitutes the directly elected representative institution at Union level, and which is premised on the assumption that the European decisionmaking process is separate from decision-making at the national level. ${ }^{11}$ Thus, according

$7 \quad$ R. Corbett, F. Jacobs, M. Shackleton, The European Parliament, $8^{\text {th }}$ ed., John Harper Publishing: London, 2011, p. 2.

8 A. Menon, J. Peet, “Beyond the European Parliament: Rethinking the EU's Democratic Legitimacy”, (2010) Centre for European Reform Essays, p. 1.

9 The wording was changed from the term "representatives of the peoples of the states brought together in the Community" to which the old provision referred (ex-Article 190(1) EC Treaty) into "representatives of the Union citizens" under Article 14 TFEU.

10 A. Maurer, "National Parliaments in the European Architecture: From Latecomers' Adaptation towards Permanent Institutional Change?", in: A. Maurer, W. Wessels (eds.), National Parliaments on their Ways to Europe: Losers or Latecomers?, Nomos: Baden-Baden, 2001, p. 29.

11 A. Groen, T. Christiansen, "National Parliaments in the European Union: Conceptual Choices in the European Union's Constitutional Debate”, in: C. Hefftler, C. Neuhold, O. Rozenberg, J. Smith (eds.), The Palgrave Handbook of National Parliaments and the European Union, Palgrave Macmillan: United Kingdom, 2015, p. 45. 
to this view, the European Parliament directly participates in the decision-making process at EU level, while the national parliaments are responsible at the domestic level by holding their representatives at the Council and European Council to account.

National parliaments are, however, not only indirectly involved in EU decision-making. They are also accorded a direct role in the EU decision-making process, most notably through Article $12 \mathrm{TEU}$, which states that national parliaments "contribute actively to the good functioning of the Union", through various means such as being informed on draft legislation by the EU institutions, ensuring that the principle of subsidiarity is respected, taking part in the evaluation mechanisms of Union policies regarding the Area of Freedom, Security and Justice (AFSJ) and monitoring Europol and Eurojust, participating in Treaty revision procedures and being notified of applications for accessions to the EU and, lastly, by taking part in interparliamentary cooperation at EU level.

\subsection{The Debate on the role of Parliaments in the EU}

\subsubsection{First phase: 1950 s -1970 s}

\subsubsection{ECSC and EC: An international organization}

The first phase of the debate on the EC's democratic legitimacy begins in the period 19501970. ${ }^{12}$ When the European Coal and Steel Community (ECSC) was established in 1952, it was considered to be an international organization, which consequently only had to fulfill the general democratic legitimacy criteria of other international organizations. ${ }^{13}$ There exists no obligation under international law for international organizations to be democratically structured. ${ }^{14}$ The view was that the ECSC - and later the European Communities (EC) -, as an international organization, derived its legitimacy from the fact that the Member States had ratified the founding treaties and that any subsequent decisions were taken based on their will and consent. For the national parliaments of the six founding Member States, this meant a relatively limited involvement in the ESCS or EC, aside from their ratification powers. The problem with the latter is, however - not only here, but indeed at any stage of the European integration process when it comes to national parliamentary ratification powers - that parliamentary input is usually reduced to simply saying yes or no to the already negotiated deal. The negotiation process is reserved for the execu-

12 Nettesheim, supra note 6, p. 362.

13 A. von Bogdandy, "The European Lesson for Democracy: The Significance of Articles 9-12 EU Treaty for International Organizations", (2012) 23 The European Journal of International Law, p. 333.

14 A. Randelzhofer, "Zum Behaupteten Demokratiedefizit der Europäischen Gemeinschaft”, in P. Hommelhoff, Der Staatenverbund der Europäischen Union: Beiträge und Diskussionen des Symposiums am 21./22. Januar 1994 in Heidelberg, Heidelberg Müller Juristischer Verlag: Heidelberg, 1994, p. 40. 
tive, with parliaments having very little say in it as would often be the case in relation to foreign policy. ${ }^{15}$ Thus, the chambers of the six national parliaments in question had very little incentive or reason to adapt their structures or procedures to their States' membership in the ECSC or EC. ${ }^{16}$ Consequently, the EC was based on the notion of indirect legitimacy, with the achievement of its own democratic legitimacy not being amongst its predominant aims.

Nevertheless, the ECSC Common Assembly was created in 1952 with the intention of providing more democratic accountability within the ECSC. ${ }^{17}$ Germany, in particular, pushed for the creation of a representative assembly in order to supervise the High Authority, to which important supranational competences with regard to the management of coal and steel was transferred. ${ }^{18}$ And yet, the predominant view at the time was that the ECSC had no need for its own legitimacy that was independent from the legitimacy of its Member States. Instead, the democratization of the European Communities by means of increasing the powers of the European Parliament was merely seen as a way to further the European integration process. More parliamentary democracy at supranational level was assimilated with taking closer steps towards a federation, but it was not considered to be an aim in itself that should be achieved. ${ }^{19}$ Thus, it is not surprising that based on this rationale - which was accompanied by French reluctance and Benelux indifference -, that the ECSC Common Assembly was created more as an "after-thought"20 and it remained largely without any significant powers except for the power to control the High Authority through a motion of censure. ${ }^{21}$

Moreover, the members of the assembly were not directly elected. Instead, they were appointed by their national parliaments from the ranks of national parliamentarians, resulting in a dual mandate of the members - a national one and a European one. This system of dual mandates did not change following the entry into force of the Treaty of Rome (1957), which created the European Communities. Under these treaties, the European Parliamentary Assembly (Assembly) - which the ECSC Common Assembly was renamed as - took over as the parliamentary assembly for both the European Community and EURATOM. ${ }^{22}$ While discussions on democratic control in the EC continued, ${ }^{23}$ the focus

15 P. Kiiver, The National Parliaments in the European Union - A Critical View on EU Constitution-Building, Kluwer: The Hague, 2006, p. 11.

16 P. Norton, "Conclusion: Addressing the Democratic Deficit", (1995) 1 Journal of Legislative Studies, p. 177.

17 Y. Meny (ed.), Building Parliament: 50 Years of European Parliament History 1958-2008, Office for Official Publications of the European Communities: Luxembourg, 2009, p. 34.

18 Nettesheim, supra note 6, p. 362.

19 Ibid.

20 M. Shackleton, “The European Parliament”, in J. Petersen, M. Shackleton (eds.), The Institutions of the European Union, $3^{\text {rd }}$ ed., Oxford University Press: Oxford, 2012, p. 126.

21 Ibid.; Article 24, 1951 Treaty of Paris.

22 Meny, supra note 17, p. 13.

23 Nettesheim, supra note 6, p. 362. 
of the Rome Treaties and of the EC during that period was on economic integration. Holding direct elections at a non-national level was simply not considered to be a priority at that time. ${ }^{24}$ As a consequence, both the EC and its representative assembly enjoyed no direct but only indirect legitimacy.

\subsubsection{Direct elections of the European Parliament: Separating the national and European parliamentary mandates}

The system whereby MEPs were sent from amongst the ranks of NPs had two serious drawbacks. ${ }^{25}$ Firstly, national parties were not equally represented in the EP. Parties that were not elected to their national parliaments could, as a consequence, not be represented in the EP. ${ }^{26}$ Moreover, even those parties sitting in the national parliaments were not equally represented. Because the MEPs had to be nominated by the national parliaments, it was only very rarely that euro-skeptics were assigned to the EP, because they either did not tend to put their names forward for nomination or were not nominated by their parliament at all. ${ }^{27}$ In addition, certain parties seemed to be excluded from the EP delegations. For example, in Italy and France, members of the Communist parties were not sent to the European Parliament until 1969 and 1973 respectively. ${ }^{28}$

Secondly, there was the issue of the effectiveness of the dual mandate. As the primary commitment of the parliamentarians was to their national citizens in their own State, the amount of time that they could spend on activities for the Assembly was rather limited and their priorities naturally lay with domestic issues. These two issues had an impact on

24 Meny, supra note 17, p. 35.

25 However, there were also advantages to this system of dual mandates. Stewart illustrates them with regard to British MEPs as follows: "The fact that these persons would be full members of the Westminster Parliament would ensure that the political parties would take a keen interest in their election. This, together with the fact that they would be elected at the same time as the Westminster Parliament, would ensure a reasonably high poll. The problem - always mentioned in any discussion of direct elections - of how to forge a link between members of the European Assembly and their national Parliaments, would be automatically solved. Moreover, they would be persons fully in touch with the political life of the country. It could well happen that a member, after serving for some years as one of these European-British members, might decide to stand for an ordinary British constituency; equally there could be shifts in the opposite direction. An able young man or woman, nursing the legitimate ambition of becoming a Minister one day, would not need to fear - as in present circumstances, or under the plan now being considered by European governments, he well may - that by "going to Europe" he cuts himself off from a political career at home. These are considerable advantages; but it remains true that, under this or similar plans, there is still no one election date for the European Assembly - it would remain a Parlement des Patries." See: M. Stewart, "Direct Elections to the European Parliament (With special Reference to the United Kingdom)", (1976) 13 Common Market Law Review, p. 285.

26 D. Watts, C. Pilkington, Britain in the European Union Today, Manchester University Press: Manchester, 2005, pp. 196-197.

27 Ibid.

28 S. Guerrieri, “The Evolution of the European Parliament's Role before the Direct Elections (1952-1979)", in: D. Preda, D. Pasquinucci (eds.), The Road Europe Travelled Along - The Evolution of the EEC/EU Institutions and Policies, P.I.E. Peter Lang: Brussels, 2010, p. 212; Meny, supra note 17, p. 35. 
the Assembly's legitimacy: how could an institution represent citizens, if it is not representative of the citizens it was supposed to represent and if it had only a very limited commitment to those citizens $?^{29}$ On the other hand, if the Assembly possessed such limited powers, why even bother to directly elect it? ${ }^{30}$ This goes hand in hand with the EP's contention that "the electorate would only take it seriously as a parliamentary body if its powers were more extensive."

As early as 1960 the European Parliament ${ }^{32}$ itself promulgated a convention in order to kick start the process towards its direct elections. ${ }^{33}$ However, this plan was not successful because the Council of Ministers could not reach unanimity on this matter, mainly due to French opposition. ${ }^{34}$ After the reaction (or lack thereof) to the convention by the Member States, the idea of direct elections was temporarily discarded by the EP, whose attention was diverted to the rising problems of European integration, ${ }^{35}$ most notably the empty chair crisis in 1965 and the Luxembourg compromise that was reached in 1966. In 1969 , a new resolution ${ }^{36}$ was tabled in the EP in order to re-launch the debate on its direct elections. In the resolution, the EP asked the Council to reconsider the matter and it reminded the Council that it could potentially take it to court, if it failed to act. ${ }^{37}$ Nevertheless, little progress was made with regard to the issue in the following years because the Council was occupied with the accession of the United Kingdom, Ireland and Denmark to the Community. ${ }^{38}$ After the enlargement of the EC in 1973, the debate on the democratic nature of the EC resurfaced. On the national parliamentary side, the parliaments of all three acceding countries joined with a newly established European Affairs Committee in tow, ${ }^{39}$ which would partially serve as a role model to other national parliaments. On the European parliamentary side, the EP launched a new report on its direct elections in $1974 .^{40}$ In 1976, the Act concerning the election of the members of the Assembly by direct universal

29 Meny, supra note 17, p. 35.

30 N. Lasan, "How Far Can the European Parliament Correct the European Union's Democratic Deficit?", (2008) 8 Romanian Journal of European Affairs, p. 21.

31 H.G. Schermers, N.M. Blokker, International Institutional Law: Unity Within Diversity, Koninklijke Brill NV: Leiden, 2011, p. 419.

32 The European Parliamentary Assembly renamed itself as the "European Parliament" in 1962 in an attempt to emphasize the political role it was to play in the future of the EC.

33 For the process that led towards direct elections to the EP, see: F. Piodi, "Towards Direct Elections to the European Parliament - Paper Written to Mark the $30^{\text {th }}$ Anniversary of Direct Elections", (2009) DirectorateGeneral for the Presidency Archive and Documentation Centre (CARDOC) Journal.

34 Meny, supra note 17, p. 36; Piodi, supra note 33, p. 25; Guerrieri, supra note 28, p. 212.

35 Piodi, supra note 33, pp. 27-28.

36 European Parliament, Resolution of 12 March 1968 on the election of members of the European Parliament [1968] OJ C41/12.

37 Piodi, supra note 33, p. 28.

38 Ibid., p. 31.

39 Norton, supra note 16, p. 178.

40 Piodi, supra note 33, p. 34. 
suffrage $^{41}$ was adopted by the Council of Ministers, which was able to reach unanimity after a shift in attitude in France following the election of Valéry Giscard d'Estaing as President. ${ }^{42}$ The first direct elections then took place between 7 and 10 June 1979 and the European Parliament, consisting of 410 members, held its constituent session from 17 to 20 July $1979 .^{43}$

These first direct elections to the European Parliament were seen as a fundamental and revolutionary step in the European integration process and for European democracy. It provided the EP with fresh legitimacy, which it used in order to strengthen its powers and to take part in the Community decision-making process. ${ }^{44}$ However, this legitimacy was limited to the Parliament; the democratic legitimacy of the EC could not be deduced from the existence of direct elections alone. ${ }^{45}$

\section{0s: Increasing budgetary powers for the European Parliament and the beginning of adaptation in national parliamentary chambers}

The Treaties of Luxembourg (1970) and Brussels (1975) were the first treaties to extend the European Parliament's budgetary powers, giving to it the right to reject, amend or approve the budget. ${ }^{46}$ The main reason behind this move was the revision that was carried out to the system of Community financing, which was previously based on national contributions linked to each Member State's gross national product (GNP). The introduction of a system of the Community's own resources, ${ }^{47}$ whereby the resources collected by the Member States on behalf of the Community legally belonged to the latter, also meant that national parliaments lost their power to effectively control Community finance. As a means of compensation for the loss at the national level, corresponding powers were thus accorded to the parliamentary organ at the European level, i.e., the European Parliament. ${ }^{48}$ For the $\mathrm{EP}$, having this power meant that it could effectively influence decision-making in the EC by blocking other institution's decisions that were contingent on Community financing. ${ }^{49}$ However, it still did not possess any formal legislative powers.

This discrepancy between the Council's legislative powers and the EP's budgetary powers in turn led to the introduction of the conciliation procedure between the institutions

41 Act concerning the election of the representatives of the Assembly by direct universal suffrage [1976] OJ L278/5. What is interesting to note is that throughout the act are the terms 'democracy' or 'legitimacy' are referred to.

42 Meny, supra note 17, p. 35.

43 Ibid., p. 36.

44 Ibid., p. 37.

45 Randelzhofer, supra note 14, p. 43.

46 Shackleton, supra note 20, p. 128.

47 Now to be found under Article 311 TFEU.

48 Shackleton, supra note 20, p. 128.

49 K. Lenaerts, P. van Nuffel, Constitutional Law of the European Union, $2^{\text {nd }}$ ed., Sweet \& Maxwell Limited: London, 2005, p. 584. 
in 1975. For 'acts with significant financial implications', ${ }^{50}$ a conciliation committee with an equal number of representatives of both institutions was to be established in cases of diverging positions between the two institutions and it was designed in order to find a compromise to the dispute. Nevertheless, the final power to adopt the legislative act still belonged to the Council. ${ }^{51}$ This, of course, meant that Member States retained the power to block any undesirable decisions that were taken at the European level, as the Council decided on the basis of the unanimity rule. This fact, in conjunction with the fact that the European Communities still had competences in only very limited fields under the Treaties, led most observers to believe that "no genuine deficit of democratic control could be observed" in the EC. ${ }^{52}$

Alongside the increase in the European Parliament's budgetary powers, as well as its first direct elections and thus a separation of the mandates of MEPs from the mandates of the national MPs, the 1970s also saw the beginning of a process of adaption by the national parliaments to the European integration process. During the early years of the ECSC and the EC, they neither had a formal role in the decision-making process at EC level nor did they seek one. Instead, European integration was considered to be a favourable aim by both the elite and the mass opinion and thus national parliamentary involvement therein was not deemed to be necessary, as unpopular proposals could easily be stopped by the government representatives in the Council in any case. ${ }^{53}$

This changed with the first enlargement in 1973, when the United Kingdom, Denmark and Ireland joined the European Communities. The parliaments of the UK and Denmark, right from the very beginning of their membership in the EC, did not follow the passive approach of the original six national parliaments but were more hands-on and vocal in their participation. ${ }^{54}$ All three parliaments established committees either prior to or after their accession to the EC so as to deal with their membership therein, even though the success of such committees varied. ${ }^{55}$

Overall, EC democratic legitimacy was still based on the Member States, their consent and their power to veto any undesirable decisions.

50 Joint Declaration by the European Parliament, the Council and the Commission of 4 March 1975 on the institution of a conciliation procedure between the Parliament and the Council, applicable to acts with significant financial implications [1975] OJ C89/1.

51 Corbett, Jacobs, Shackleton, supra note 7, p. 4.

52 Nettesheim, supra note 6, p. 362.

53 Norton, supra note 16, p. 177.

54 Ibid., p. 178.

55 Ibid. 


\subsubsection{SEA: Shift towards supranational powers and a loss of national parliamentary powers}

The signing of the Single European Act (SEA) in 1986 marked a turning point in the discussions on the democratic credentials of the EC. ${ }^{56}$ As long as its actions were viewed as serving the interests of all the Member States, no democratic legitimacy was thought to be needed at the European level. However, with the launch of the European single market programme in the SEA, the EC began to expand beyond a mere customs union. The continuing transfer of powers from the national to the European level meant a loss of influence for national parliaments on policy-making. At the same time, there was a need for the abolition of non-tariff barriers to trade in order to ensure the free movement of goods between the Member States. This was done by harmonizing nationally sensitive areas such as national health, safety and environmental regulations: thus transferring decision-making powers from the national level to the supranational level in these areas. Because such regulations differed from one Member State to the next and because there was no consensus on what a European regulation should look like, qualified majority voting was introduced in the Council of Ministers in order to prevent any potential deadlock from taking place. ${ }^{57}$ QMV slowly began to replace the unanimity rule in certain policy areas as the default general decision-making procedure in the Council. This meant that the Member States no longer retained a veto right in decisions that they deemed undesirable, which in turn was perceived to undermine the national democratic processes in the Member States, ${ }^{58}$ who "became subjected to a supranational power that could be exerted against their will." 59

Realizing the changing conditions of their EC membership - both regarding the extension of decision-making powers at the EC level and the shift of such decision-making powers $^{60}$ - national parliaments began to adapt their procedures regarding EC affairs at this time. Even though the European Parliament's powers were also extended with the extension of EC competences, this was not deemed sufficient from a democratic point of view, as will be discussed below. Therefore, from the mid-1980s onwards, a trend could be observed whereby the national parliaments of the EC Member States attempted to increase their involvement in EC matters by establishing specialized EC affairs committees,

56 Nettesheim, supra note 6, p. 362.

57 Scharpf, supra note 1, pp. 21-22.

58 B. Rittberger, “Constructing Parliamentary Democracy in the European Union: How Did It Happen?", in B. Kohler-Koch, B. Rittberger (eds.), Debating the Democratic Legitimacy of the European Union, Rowman \& Littlefield Publishers: USA, 2007, pp. 117, 133; B. Steunenberg, J.A.A. Thomassen (eds.), The European Parliament: Moving Toward Democracy in the EU, Rowman \& Littlefield Publishers: Oxford, 2002, p. 5.

59 Nettesheim, supra note 6, p. 363.

60 Norton, supra note 16, p. 178. 
increasing their activity in the EC areas and trying to engage more with MEPs. ${ }^{61}$ As was mentioned above, the Danish Folketing had already established an EAC before joining the European Communities in 1973. This committee, often considered to be one of the strongest European Affairs Committees when it comes to its ability to bind government to a certain position, ${ }^{62}$ would later also serve as an example for the EACs of other parliaments such as the Swedish Riksdag or the Austrian Nationalrat. ${ }^{63}$ Moreover, the UK parliament and the Irish parliament established a European Affairs Committee - in 1974 and 1973 respectively - shortly after they joined the European Communities. ${ }^{64}$

For other Member States, it took a bit longer after their accession for them to establish an EAC. Thus, the French parliament created an EAC in 1979, while in Germany, the Bundestag did not establish a standing committee on EU affairs until the end of 1992, after the Treaty of Maastricht was signed, even though there had been an EAC in the Bundesrat since 1957. ${ }^{65}$ In the Dutch parliament, the EACs were established in 1994 (Tweede Kamer) and 1970 (Eerste Kamer) respectively. ${ }^{66}$ In Italy the Senate established such a committee in 1970, whereas the Camera dei deputati only did so in 1990. In Belgium and Luxembourg, the EACs were established between 1985 and $1990 .{ }^{67}$

In general, however, the view that EC democratic legitimacy was based on the democratic accountability of the national governments of the Member States could no longer be maintained to the fullest, despite the (slow) changes that were made at national level regarding parliamentary involvement in EU affairs. While the Council was still made up of national ministers and their representatives from the Member States, whom are permanently instructed by the national executives, including the possibility of being re-instructed or recalled at any time, ${ }^{68}$ the introduction of the QMV procedure blurred the line of accountability between the ministers and their national parliaments. ${ }^{69}$ Even a careful instruction of national ministers - and their compliance with these instructions - could not change the fact that the QMV procedure made it possible for their vote to be overridden by the ministers of other Member States. As Weiler puts it:

61 Ibid., p. 179.

62 See for example: T. Bergman, "National Parliaments and EU Affairs Committees: Notes on Empirical Variation and Competing Explanations”, (1997) 4 Journal of Public Policy, p. 377.

63 Kiiver, supra note 15, p. 48.

64 M. MacCarthaigh, “Accountability through national parliaments: practice and problems”, in: J. O’Brennan, T. Raunio (eds.), National Parliaments Within the Enlarged European Union - From 'Victims' of Integration to Competitive Actors?, Routledge: United Kingdom, 2007, p. 38.

65 L. C. Blichner, "The Anonymous Head of Public Reason - Interparliamentary Discourse and the Quest for Legitimacy”, in: E.O. Eriksen, J.E. Fossum (eds.), Democracy in the European Union - Integration through Deliberation?, Routledge: USA, 2000, pp. 145-155.

66 Ibid.

67 Ibid.

68 See for example: A. Moravcsik, "In Defence of the 'Democratic Deficit': Reassessing Legitimacy in the European Union”, (2002) 40 Journal of Common Market Studies, p. 619.

69

Meny, supra note 17, p. 36. 
[T] he single most legitimating element [of the EC] was the Luxembourg Accord and the veto power. To be sure, one paid a huge cost in terms of efficient decision-making and progress. But it was this device that enabled the Community to legitimate its program and its legislation, for it provided both an ex-ante 'insurance policy' to the national electorates that nothing could get through without their voice having a controlling say and it presented an ex-post legitimation as well. Everything that the Community did, however unpopular it might have been, was passed with the assent of national ministers. [...]. The restoration of majority voting in the Community] may exacerbate legitimacy problems, [which] even a beefed up European Parliament (which also operates on a majority principle) will not necessarily solve. ${ }^{70}$

This shift of powers towards the European level meant a power shift in favour of technocratic and bureaucratic institutions, which was not accompanied by the strengthening of parliamentary control. ${ }^{71}$ More European integration meant more executive power and less national parliamentary control; all the while on the European level there was only a European Parliament that saw itself unable to compensate for that loss of national parliamentary control due to its limited powers. At the same time, there was a danger that the national parliaments, which were becoming aware of their loss of powers, would be reluctant to agree to any reform relating to Community decision-making or Community competences, including reforms to the powers of the European Parliament. ${ }^{72}$

While there was a shift in attitude towards the recognition of a need for the involvement of the EP in the legislative process, especially in areas to which QMV was extended, ${ }^{73}$ such reforms remained rather limited in the Single European Act. This did not mean that the EP was not given more participation rights in the Community decision-making process, however. Under the SEA, there were four forms of parliamentary involvement in the legislative process: ${ }^{74}$ first, where the Treaty so required, the Council had to consult the European Parliament. This compulsory consultation was the traditional form of parliamentary involvement. Second, the Council could also choose to consult the Parliament without being under an explicit obligation to do so. Third, parliamentary approval was needed for

70 J.H.H. Weiler, “After Maastricht: Community Legitimacy in Post-1992 Europe”, in W.J. Adams (ed.), Singular Europe - Economy and Polity of the European Community after 1992, University of Michigan Press: USA, 1995, p. 24.

71 C. Archer, The European Union: Structure and Process, $3^{\text {rd }}$ ed., Continuum International Publishing: New York, 2000, p. 58.

72 R. Bieber, J. Pantalis, J. Schoo, "Implications of the Single Act for the European Parliament", (1986) 23 Common Market Law Review, p. 792.

73 Rittberger, supra note 58, p. 120; see also: European Parliament, Resolution of 31 May 2001 on the Treaty of Nice and the future of the European Union.

74 Bieber, Pantalis, Schoo, supra note 72, pp. 772-773. 
the entry into force of accession and association agreements. ${ }^{75}$ Fourth and lastly, a new procedure was introduced by Articles 6 and 7 of the SEA which was known as the cooperation procedure. This procedure was primarily applicable to acts creating the internal market (Article 8A EEC Treaty), except for tax harmonization, on which the EP was merely consulted. ${ }^{76}$ Under this procedure, the EP and the Council legislated together, and the EP could have two readings - instead of one - of proposed legislation. The Council still retained a veto right under this procedure, but this was limited by a unanimity requirement where the proposed legislation was supported by the Commission. ${ }^{77}$

The importance of the involvement of the European Parliament in the EC legislative process was already recognized by the European Court of Justice (ECJ) in 1980. In the socalled Isoglucose judgment, the ECJ set aside a Council regulation on the basis that it was adopted before the EP could submit its opinion thereon. ${ }^{78}$ In the ECJ's view, the consultation procedure under Article 43(2) of the EC Treaty ensured that the Parliament could be involved in the Community legislative process. Consequently, disregarding this procedure constituted an infringement of essential procedural requirements. ${ }^{79}$ The ECJ also referred to democracy as a legal principle for the first time ${ }^{80}$ and linked the Parliament's consultation right to the democratic character of the Community by stating that

[s] uch a power represents an essential factor in the institutional balance intended by the Treaty. Although limited, it reflects at Community level the fundamental democratic principle that the peoples should take part in the exercise of power through the intermediary of a representative assembly. ${ }^{81}$

It hence made the involvement of Parliament in the legislative process not only a possibility, but an absolute necessity for democracy in the EC, albeit only through the consultation right. $^{82}$

But despite all these changes and the improved role of the EP in the EC decisionmaking process, European integration - entailing a gradual increase in the powers of the EC - was still moving forward faster than the EC's democratization process, which seemed

75 Articles 237 and 238 of the EEC Treaty.

76 Bieber, Pantalis, Schoo, supra note 72, p. 774.

77 Shackleton, supra note 20, p. 129.

78 Case 138/79 Roquette Frères v. Council [1980] ECR 3333197 (Isoglucose case).

79 Ibid., paras. 32-33.

80 Von Bogdandy, "A Disputed Idea Becomes Law: Remarks on European Democracy as a Legal Principle”, in B. Kohler-Koch, B. Rittberger, Debating the Democratic Legitimacy of the European Union, Rowman \& Littlefield Publishers: USA, 2007, p. 34.

81 Isoglucose case, supra note 78, para. 33.

82 For an analysis of Parliament's power to delay through the consultation procedure see: R. Kardasheva, "The Power to Delay: The European Parliament's Influence in the Consultation Procedure", (2009) 47 Journal of Common Market Studies, pp. 385-409. 
to be more sedentary in nature, leading to a growing gap between the two. ${ }^{83}$ What is interesting to note is that while the SEA was the marking point for the beginning of any meaningful discussions on the democratic legitimacy of the EC, such a debate did not reach a wide public audience. Instead, the idea of a single market was perceived as being non-political, aspirational for economic and social welfare conditions that could not reasonably be debated politically or challenged. ${ }^{84}$

Thus, EC democratic legitimacy began to emerge as the subject of academic discussion in the 1980s, when the loss of parliamentary powers at the national level were partially and supposedly to be compensated by the European Parliament at EC level. But it was not until the 1990s and the entry into force of the Treaty of Maastricht that the question of and the concern about a democratic deficit and a 'deparliamentarization' in the European Union became a wide-spread debate. ${ }^{85}$

\subsubsection{Third phase: Since mid-1990s}

\subsubsection{EU: A genuine political public power and the recognition of the role of national parliaments at EU level}

With the signing of the Treaty of Maastricht in 1992, the European integration process made a significant leap forward, triggering the third phase of the debate on democratic legitimacy in the EU. ${ }^{86}$ It was with the Treaty of Maastricht and the referenda thereon in Denmark and France that the discussion on EU democratic legitimacy attracted widespread public attention. ${ }^{87}$ There was a general consensus that the EU was now much more than a mere economic organization and that it had turned into a 'genuine political public power'. The introduction of a European currency, the Euro, was not only the peak of the economic integration process hitherto, it was also "a profoundly political act, because a currency is not just another economic factor but also symbolizes the power of the sovereign who guarantees it." 88 This was the first time that one of the "essential sovereign rights of the modern state - currency, internal security and external security - was, for the first time,

83 Nettesheim, supra note 6, p. 362.

84 Ibid., p. 363.

85 Ibid., von Bogdandy, supra note 80, p. 33.

86 Nettesheim, supra note 6, p. 363; A. Wimmel, “Theorizing the Democratic Legitimacy of European Governane: a Labyrinth with No Exit?”, (2009) 31 European Integration, p. 182; T. Raunio, “Always One Step Behind? National Legislatures and the European Union”, (1999) 34 Government and Opposition, p. 180.

87 Scharpf, supra note 1, p. 19.

88 J. Fischer, "From Confederacy to Federation: Thoughts on the Finality of European Integration", Speech at the Humboldt University in Berlin, 12 May 2000, in: C. Joerges, Y. Meny, J.H.H. Weiler (eds.), What Kind of Constitution for What Kind of Polity? - Responses to Joschka Fischer, Robert Schuman Centre for Advanced Studies, European University Institute: Florence, 2000, p. 22. 
transferred to the sole responsibility of a European institution." ${ }^{89}$ The Treaty also introduced the concept of European citizenship and significantly enhanced the role of the European Parliament in the decision-making process.

The debate on the EU's democratic legitimacy during the 1990s was primarily focused on its input side and the EU's democratic processes. ${ }^{90}$ It was in the Treaty of Maastricht that national parliaments were, for the first time, mentioned in the declarations annexed to the Treaties. Declarations 13 and 14 stated that the greater involvement of national parliaments was to be encouraged in the EU. Therein, the IGC called for an exchange of information between the national parliaments and the EP, as well as a scrutiny mechanism, which would ensure that national parliaments receive legislative proposals by the Commission from their national governments in good time. It furthermore called for a Conference of the Parliaments between the European Parliament and the national parliaments, to be "consulted on the main features of the European Union, without prejudice to the powers of the European Parliament and the rights of the national parliaments." Because this was only laid down in a declaration, however, it was not binding on the national governments and EU institutions. This changed following the entry into force of the Treaty of Amsterdam, which provided an information right to national parliaments in a Protocol that was attached to the Treaties. It also gave the Conference of European Affairs Committees (COSAC) the power to "make any contributions it deems appropriate for the attention of the institutions of the European Union", even though such contributions were non-binding on the national parliaments and could not prejudice their positions. With regard to the information rights of national parliaments, the Protocol stated that all Commission consultation documents such as green and white papers and communications were to be forwarded to the national parliaments "promptly." At the same time, the Commission's legislative proposals were to be made available to the national governments "in good time" so that the latter could forward them to their national parliaments. There was no direct information right for national parliaments in that they would receive such proposals from the Commission itself; instead this would be done via their national governments and it thus depended on what the latter deemed as "appropriate": ${ }^{91}$

The powers of the European Parliament were notably expanded by the provisions of the Treaty of Maastricht. Imperatively, it created a new decision-making procedure: the co-decision procedure. This procedure was similar to the cooperation procedure, but it put the European Parliament on an equal footing with the Council by giving it the right to reject legislative proposals if no compromise between the two institutions could be found, even after a conciliation committee had been convened. Thus, it gave Parliament

89 Ibid.

90 Scharpf, supra note 1, p. 19.

91 Treaty of Amsterdam, Protocol on the role of national parliaments in the European Union. 
the right to veto any legislative proposal without the Council being ultimately able to overrule its veto. The co-decision procedure was a "truly novel feature" of the Treaty of Maastricht, ${ }^{92}$ and applicable to about one third of the legislative areas, thereby significantly elevating the EP's status in the legislative procedure.

The co-decision procedure was later extended by the Treaties of Amsterdam (1997) and Nice (2001) in order for it to become applicable to almost every legislative area, including parts of the Judicial and Home Affairs (JHA) pillar, which was not provided for by the Treaty of Maastricht. The Treaty of Amsterdam also simplified the procedure by allowing for the adoption of a legislative act at first reading, where both the EP and the Council were in agreement. Both the cooperation procedure, established by the SEA, and the assent procedure were extended to more legislative areas following the entry into force of the Treaties of Maastricht, Amsterdam and Nice. Parliamentary assent was required for all international agreements that set up institutional frameworks and cooperation procedures, that had important budgetary implications for the Community or that required implementing legislation in relation to which the new co-decision procedure was to be applied, as well as in some other areas. ${ }^{93}$ It was, however, not extended to treaty revisions, measures of Community-own resources or the flexibility clause, because doing so would "have given Parliament the power to hold up future ICGs for 'ransom' and condition parliamentary assent on a full acceptance of Parliament's demands for more power."

The Treaty of Maastricht gave the European Parliament the power of final approval over the membership of the entire body of the Commission (also meaning a de facto veto power on individual nominees for the Commission), giving it important control over the EU executive. This was in addition to its power to dismiss the executive, which originated in the ECSC Treaty almost 50 years earlier. ${ }^{95}$ The EP also had a right to be consulted on the candidate that was nominated for President of the Commission, ${ }^{96}$ and the Treaty of Amsterdam then later subjected the appointment of the President of the Commission to its approval as well. ${ }^{97}$ Other additional parliamentary powers provided for by the Treaty of Maastricht were the establishment of parliamentary committees of inquiry, the power to appoint a European Ombudsman and an indirect right of initiative by giving it the possibility to ask the Commission to present a certain legislative proposal. ${ }^{98}$

\footnotetext{
92 Weiler, supra note 70, p. 17.

93 Ibid., p. 15.

94 Ibid., p. 16.

95 Shackleton, supra note 20, p. 129.

96 Corbett, Jacobs, Shackleton, supra note 7, p. 292.

97 For more detailed information on the process that led to these Treaty changes, see: Corbett, Jacobs, Shackleton, supra note 7. For an analysis of the EP's legislative powers after the Treaty of Amsterdam, see: A. Maurer, "The Legislative Powers and Impact of the European Parliament", (2003) (41) Journal of Common Market Studies, pp. 227-247.

Shackleton, supra note 20, p. 129.
} 
One of the reasons for this increase in parliamentary legislative power was the widespread recognition that the EU was no longer an international organization ${ }^{99}$ with a clearly defined (economic) mandate. It had turned into a 'genuine political public power', which could no longer be legitimized by the consent of its Member States in signing the founding treaties. ${ }^{100}$ The extension of qualified majority voting into more legislative areas entailed a loss of power at the national level and thus a loss of power for national parliaments. This loss was, again, to be compensated by improving the role of the EP. ${ }^{101}$ The Union had to find its own source of legitimization by extending the powers of the European Parliament. ${ }^{102}$ After years of stagnation, the European integration process was given a considerable boost by the signing of the Treaty of Maastricht. This led to a "three-dimensional dynamic" that "must be seen as the initiation for the normative legitimacy and/or democracy debate."103 The first was the growing skepticism and disapproval of the European Union from the perspective of the Member States, which was exemplified by the negative referenda in the Netherlands and France in 2005. Second, both the German Federal Constitutional Court and the Danish Supreme Court were confronted with the question of whether the loss of national sovereignty to the EU was consistent with their respective constitutional orders. And lastly, the possibility of majority decisions at EU level, including in the Parliament, resulted in the possibility that some Member States could be overruled by others. These three post-Maastricht events had as a consequence the beginning of an "extraordinarily intricate and controversial debate on the legitimacy of European governance", ${ }^{104}$ which is still being discussed today.

The growing skepticism following the signing of the Treaty of Maastricht led to the adoption by the European Council in Laeken of the "Declaration on the Future of the European Union", which committed the EU to more democracy, transparency and efficiency. One of the main questions in this debate was whether democratic legitimacy should be enhanced by strengthening the role of the European Parliament. ${ }^{105}$ It also put the question of the role of national parliaments on the agenda to be discussed, referring to, for example, a new institution made up of national parliaments alongside the EP and the Council, the national parliaments' role in EU areas in which the EP has no competence,

99 For a differing opinion see: Randelzhofer, supra note 14, p. 40.

100 Nettesheim, supra note 6, pp. 363-364.

101 Shackleton, supra note 20, p. 129.

102 See, for example: European Council, Presidency Conclusions, Dublin Council, 25-26 June 1990, SN 60/1/90; European Council, Presidency Conclusions, Rome Council, 14-15 December 1990, SN 242/1/90.

103 Wimmel, supra note 86, p. 182.

104 Ibid.

105 European Council, Laeken Declaration of 15 December on the future of the European Union, Annex I to Presidency Conclusions, Laeken Council, 14-15 December 2001, SN 300/1/01. 
and their possible involvement in a "preliminary checking of compliance with the principle of subsidiarity." 106

After the failure of the Constitutional Treaty in 2005, the Treaty of Lisbon was signed in 2007 as a form of compromise, retaining the most important elements of the Constitutional Treaty but leaving out some of the more controversial elements such as the flag, anthem and motto. It greatly enhanced the EU's input democratic legitimacy by making it more parliamentary in nature, ${ }^{107}$ and which was "all about formalizing and consolidating the role of the Parliament as a co-legislator." ${ }^{108}$ The following section will examine this development by exploring, in more detail, firstly the role of national parliaments in the EU under (1) EU law and (2) national law, as well as the three main functions of the European Parliament as per the Treaty of Lisbon, ${ }^{109}$ namely its (1) legislative powers, (2) budgetary powers and (3) scrutiny powers over the executive.

\subsection{National parliaments under the Treaty of Lisbon}

One can distinguish between two types of national parliamentary powers in EU affairs. First, there are those powers that are entrenched in EU primary law, under which all national parliaments in the EU are subject to the same rules. Second, there are the powers given to national parliaments in EU affairs under national law. Here, the powers of each national parliament vary according to its own constitutional and statutory provisions. ${ }^{110}$ This chapter will only deal with the powers given to national parliaments under EU primary law; the second category of powers will be discussed in more detail in Chapter 4.

106 Ibid.

107 P. Craig, The Lisbon Treaty - Law, Politics, and Treaty Reform, Oxford University Press: Oxford, 2010, p. 72.

108 L. Pech, "The Institutional Development of the EU Post-Lisbon", in D. Ashiagbor, N. Countouris, I. Lianos (eds.), The European Union after the Treaty of Lisbon, Cambridge University Press: Cambridge, 2012, p. 29. For a discussion on EU democratic legitimacy after Lisbon see, for example: K. Lenaerts, N. Cambien, "The Democratic Legitimacy of the EU after the Treaty of Lisbon", in J. Wouters, L. Verhey, P. Kiiver (eds.), European Constitutionalism beyond Lisbon, Intersentia: Antwerp, 2009, pp. 185-207; Craig, supra note 107; R. Matarazzo (ed.), Democracy in the EU after the Lisbon Treaty, Edizioni Nuova Culture: Rome, 2011; J. Mayoral, "Democratic Improvements in the European Union under the Lisbon Treaty - Institutional Changes Regarding Democratic Government in the EU", (2011) European Union Democracy Observatory (EUDO); S. Sieberson, “The Treaty of Lisbon and Its Impact on the European Union's Democratic Deficit”, (2008) 14 Columbia Journal of European Law, pp. 445-465.

109 M. Kohler, "European Governance and the European Parliament: From Talking Shop to Legislative Powerhouse", (2013) Journal of Common Market Studies, p. 3; S. Douglas-Scott, "The Law and Custom of the European Parliament”, in K.S. Ziegler, D. Baranger, A.W. Bradley (eds.), Constitutionalism and the Role of Parliaments, Hart Publishing: Oxford, 2007, p. 82.

110 O. Höing, "Differentiation of Parliamentary Powers - The German Constitutional Court and the German Bundestag Within the Financial Crisis”, (2012) OPAL Online Paper Series | 9/12, p. 11. 


\subsubsection{Powers entrenched in EU primary law}

The powers of national parliaments that are entrenched in EU primary law are predominantly laid down in Protocol $\mathrm{No}^{\circ} 1$ on the role of national parliaments in the European Union and Protocol $\mathrm{No}^{\circ} 2$ on the application of the principles of subsidiarity and proportionality, both of which are annexed to the Treaty of Lisbon. Under EU primary law, all national parliaments are granted equal powers, however, this does not mean that they are all used in the same manner and to the same extent.

\subsubsection{Information rights}

According to the aforementioned protocols, national parliaments are, first of all, accorded an information right. Article 1 of Protocol $\mathrm{No}^{\circ} 1$ obliges the European Commission to forward all Commission consultation documents, i.e., green and white papers and communications, the annual legislative programme as well as "any other instrument of legislative planning or policy" to the national parliaments at the same time that they are sent to the European Parliament and the Council. Article 2 lays down the right of national parliaments to receive draft legislative acts. Draft legislative acts originating from the Commission must be forwarded to the national parliaments at the same time that they are sent to the European Parliament and the Council. If the draft legislative act originates from the European Parliament, it is the European Parliament that forwards the necessary documentation to it national counterparts; if the draft legislative acts originate from a group of Member States, the Court of Justice, the European Central Bank (ECB) or the European Investment Bank (EIB), this task falls to the Council instead. The national parliaments are also informed on the outcome of Council meetings, including the minutes of meetings in which draft legislative acts are deliberated, at the same time as their governments (Article 5 of Protocol $\mathrm{No}^{\circ} 1$ ) and they are also to receive an annual report from the Court of Auditors (Article 7 of Protocol $\mathrm{No}^{\circ} 1$ ).

\subsubsection{Early Warning Mechanism}

Moreover, national parliaments have the right to send a reasoned opinion to the Presidents of the European Parliament, the Council and the Commission within the framework of the Early Warning Mechanism (EWM), if it considers that a draft legislative act does not comply with the principle of subsidiarity (Article 3 of Protocol $\mathrm{No}^{\circ} 1$ ). The procedure therefor is further laid down in Protocol $\mathrm{No}^{\circ} 2$. Each national parliament has two votes in bicameral systems each chamber is allocated one vote - and where the reasoned opinion represents at least a third of such votes, ${ }^{111}$ the Commission, or the institution from which

111 Where the draft legislative act falls within the Area of Freedom, Security and Justice under Article 76 TFEU, the threshold is one quarter. 
the draft originates, is obliged to review the draft. It may then maintain, amend or withdraw the draft, and it must give reasons for its decision (Articles 7(1) and (2) of Protocol No ${ }^{\circ}$ ). This is also referred to as the yellow card procedure.

Up until June 2015, the yellow card procedure has only been triggered twice. ${ }^{112}$ The first instance, in 2012, related to the Commission's proposal for a Council Regulation on the exercise of the right to take collective action within the context of the freedom of establishment and the freedom to provide services (Monti II-Proposal). ${ }^{113}$ Overall, twelve chambers amounting to a total of 19 votes submitted reasoned opinions stating that they objected to the proposal on the grounds of subsidiarity. While the Commission did not find the proposal to be contrary to the subsidiarity principle, it nevertheless decided to withdraw the proposal after considering the reasoned opinions of the national parliaments and following discussions with the relevant stakeholders. ${ }^{114}$ The second time the yellow card procedure was triggered was in 2013 and this concerned the Commission's proposal for a Council Regulation on the European Public Prosecutor's Office (the EPPO-Proposal), ${ }^{115}$ falling within the Area of Freedom, Security and Justice (AFSJ), for which only a quarter of the votes allocated to the national parliaments is required to trigger the procedure. In total, a total of 14 chambers amounting to 18 votes objected to the proposal by means of a reasoned opinion. This time the Commission concluded that the proposal was compliant with the principle of subsidiarity but, unlike in 2012, it decided to maintain the proposal and not to withdraw it. ${ }^{116}$

If the reasoned opinions that are submitted by the national parliaments to the European Commission amount to at least a simple majority of the votes allocated to them - and not merely one third - then the orange card procedure will be triggered. When this occurs, the Commission can decide to maintain the proposal, but it must give a reasoned opinion as to why it considers the draft to be compliant with the principle of subsidiarity, which, together with the reasoned opinions from the national parliaments, then must be submitted to the European Parliament and the Council. If either a majority of 55\% of the members of the Council or a majority of the votes cast in the European Parliament finds the proposal to violate the principle of subsidiarity, the legislative proposal will no longer be considered (Article 7(3) of Protocol $\mathrm{No}^{\circ}$ 2). Up until May 2016, no threshold has been reached to trigger the orange card procedure. ${ }^{117}$

112 European Commission website, The Subsidiarity Control Mechanism, available at: <http://ec.europa.eu/dgs/secretariat_general/relations/relations_other/npo/subsidiarity_en.htm> (last retrieved on 1 May 2016).

113 Ibid.

114 Ibid.

115 Ibid.

116 Ibid.

117 Ibid. 
In 2014, the European Commission received 21 reasoned opinions from 15 different chambers (out of 41 chambers) of national parliaments, covering 15 different Commission proposals but with none reaching more than three reasoned opinions at the same time. ${ }^{118}$ The most active national parliaments in 2014 were the Austrian Bundesrat and the UK House of Commons (three reasoned opinions respectively), closely followed by the Swedish Riksdag and the French Sénat (two reasoned opinions respectively). All other chambers issued either one reasoned opinion or none in that year. ${ }^{119}$ This is a significant decrease in numbers when compared to the total of 88 reasoned opinions that were received by the Commission from national parliamentary chambers in 2013, covering 36 different Commission proposals. ${ }^{120}$ This decrease can, however, be explained by the fact that there were simply fewer proposals initiated by the Commission at the end of its term before the new EP elections in May 2014. ${ }^{121}$ The most active national parliamentary chambers in 2013 were once again the Swedish Riksdag (nine reasoned opinions) and the Austrian Bundesrat (six reasoned opinions) as well as the Lithuanian Seimas (six reasoned opinions). The Spanish Congreso de los Diputadis and Senado, the Maltese Kamra tad-Deputati, the Dutch Tweede Kamer and the UK House of Commons respectively submitted five reasoned opinions in 2013. ${ }^{122}$ In 2012, the Swedish Riksdag recorded the highest number of reasoned opinions, i.e. 20, followed by the French Sénat with seven reasoned opinions, which was followed by the German Bundesrat with the submission of five reasoned opinions. ${ }^{123}$ Together, these three chambers submitted half of the overall 70 reasoned opinions that were received by the Commission in that year. ${ }^{124}$ Already in its 2012 report, the European Commission noted that reasoned opinions "continue to vary greatly in terms of their form and the type of arguments put forward." 125 This, in combination with the fact that the reasoned opinions submitted by the national parliaments rarely concern one Commission proposal but are rather dispersed over a variety of different proposals, as was also seen in the years thereafter, seems to "confirm the varying political interests of national parlia-

118 European Commission, Annual Report 2014 on Subsidiarity and Proportionality, COM(2015) 315 final, pp. 4-5. An overview over the reasoned opinions submitted by the chambers of the national parliaments in 2014 can be found at the following link: European Commission, Annex to the Annual Report 2014 on Subsidiarity and Proportionality, COM 2015 (315) final, available at: <http://eurlex.europa.eu/resource.html?uri=cellar:fe49fbf2-20bc-11e5-a342-01aa75ed71a1.0015.02/DOC_2\&format $=$ PDF $>$ (last retrieved on 23 May 2016).

119 Ibid.

120 European Commission, Annual Report 2013 on Subsidiarity and Proportionality, COM(2014) 506 final, p. 4.

121 Ibid.

122 Ibid.

123 European Commission, Annual Report 2012 on Subsidiarity and Proportionality, COM(2013) 566 final, p. 4.

124 Ibid.

125 Ibid., p. 3. 
ments." ${ }^{126}$ So even though national parliaments have the right to send reasoned opinions to the European Commission where they consider that there is a violation of the principle of subsidiarity, this is more of a collective right than an individual right, in the sense that one parliament - or parliamentary chamber - by itself only has limited influence on the continuance of the Commission's legislative proposal, if any at all. It is only together, as a collective, that national parliaments are in a position to influence the legislative process of the Union under the EWM, but this would require them to take the same positions with regard to the Commission's proposals and to cooperate in order to achieve the required threshold.

\subsubsection{Political dialogue}

In addition to the submission of reasoned opinions under Protocol 2, national parliaments may also send opinions to the European Commission within the framework of the Political Dialogue (PD). This Political Dialogue between the Commission and the national parliaments was initiated in 2006 by then-Commission President José Manuel Barroso in order to give national parliaments the possibility to react to legislative proposals, consultation documents such as green and white papers and communications, the annual legislative programme and other planning or policy documents in order "to improve the process of policy formulation." ${ }^{127}$ Under the Political Dialogue framework, the Commission undertakes to reply to national parliaments' opinions within three months; this is also the case for reasoned opinions where the latter do not meet the threshold to trigger the yellow card procedure. In 2014, the European Commission received a total of 506 opinions from national parliaments under the Political Dialogue framework. ${ }^{128}$

The most active national chamber was the Portuguese Assembleia da Republica with 118 opinions, followed by the Italian Senato della Repubblica (63 opinions), the Spanish Congreso de los Diputados and Senato (45 opinions), the Czech Senát (41 opinions), the French Assemblée Nationale (35 opinions), the Romanian Camera Deputatilor (30 opinions), the German Bundesrat (24 opinions) and the UK House of Lords (21 opinions). ${ }^{129}$ The proposal on which the most opinions were submitted was the proposal for a directive on recycling and other waste-related targets $\left(\operatorname{COM}(2014) 397\right.$ final) ${ }^{130}$ In 2013 and 2012 the number of opinions received by the Commission under the political dialogue was 621 and

126 Ibid.

127 European Commission website, The Political Dialogue, available at: <http://ec.europa.eu/dgs/secretariat_general/relations/relations_other/npo/political_dialogue_en.htm\#politicaldialogue $>$ (last retrieved on 1 May 2016).

128 European Commission, Annual Report 2014 on Relations between the European Commission and National Parliaments, COM (2015) 316 final, p. 3.

129 Ibid.

130 Ibid. 
663 respectively. ${ }^{131}$ Similar to what was concluded for the EWM, the interests of national parliaments seem to diverge as most Commission documents on which the national parliamentary chambers submitted opinions only received one to three of them at the same time. ${ }^{132}$ The chambers submitting the most opinions in 2013 and 2012 were, once again, the Portuguese Assembleia de Republica (192 opinions in 2013 and 227 opinions in 2012), the Czech Senát (64 opinions in 2013 and 46 in 2012), the German Bundesrat and the French Assemblée Nationale (40 opinions each in 2013 and 59 and 0 opinions in 2012 respectively), the Romanian Camera Deputatilor (38 opinions in 2013 and 26 in 2012) and Senatul (26 opinions in 2013 and 2 opinions in 2012), the Italian Senato della Republica (36 opinions in 2013 and 96 opinions in 2012) and the Swedish Riksdag (24 opinions in 2013 and 33 in 2012). ${ }^{133}$

\subsubsection{Ratification of Treaty amendments}

National parliaments also have the right to ratify any treaty changes. Article 48(4) TEU, pertaining to the (ordinary) treaty revision procedures states that "the amendments shall enter into force after being ratified by all the Member States in accordance with their respective constitutional requirements", which usually means through their national parliaments. This also applies to any treaty changes that are made under the simplified revision procedure (Article 48(6) TEU). If the European Council intends to make use of Article 48(7) TEU, under which it may adopt a decision authorizing the Council to act by qualified majority instead of unanimity or to have recourse to the ordinary legislative procedure instead of a special legislative procedure, it must inform the national parliaments at least six months before the decision is adopted (Article 6 of Protocol No ${ }^{\circ} 1$ ). If, within those six months after the notification, a national parliament opposes such a decision, the European Council may not adopt the latter (Article 48(7) TEU).

\subsubsection{Interparliamentary cooperation under Protocol $\mathrm{No}^{\circ} 1$}

Protocol $\mathrm{No}^{\circ} 1$ lays down the basis for the establishment of regular interparliamentary cooperation between the European Parliament and the national parliaments (Article 9 of Procotol $\mathrm{No}^{\circ} 1$ ). One important aspect of this interparliamentary cooperation is the Conference of Speakers of EU Parliaments, ${ }^{134}$ where the speakers of the national parliaments and the President of the European Parliament meet every spring in the country in which

131 European Commission, Annual Report 2013 on Relations between the European Commission and National Parliaments, COM (2014) 507 final, p. 5.

132 Ibid.

133 Ibid., p. 10; European Commission, Annual Report 2012 on Relations between the European Commission and National Parliaments, COM (2013) 565 final, p. 9.

134 The EU Speakers Conference has existed since 1963 but as the European Parliamentary Assembly was itself composed of delegates from the national parliaments of the Member States, it could be considered a form of interparliamentary cooperation itself. 
the Council Presidency was held during the second semester of the previous year. ${ }^{135}$ The objective of this conference is to "exchange opinions, information and experiences related to the role of parliaments and the organization of parliamentary functions" as well as to promote research activities and common action with regard to interparliamentary cooperation, such as the Interparliamentary EU Information Exchange (IPEX). ${ }^{136}$

Article 10 of Protocol $\mathrm{No}^{\circ} 1$ also provides for a Conference of Parliamentary Committees for Union Affairs (COSAC), which is a conference that is held between the different EU affairs committee of the national parliaments of the Member States and members of the European Parliament. In addition to the 16 MEPs that participate in this forum, each national parliament may send six representatives to the bi-annual COSAC plenary meetings. ${ }^{137}$ Under Article 10 of Protocol No ${ }^{\circ}$, COSAC may "submit any contribution it deems appropriate for the attention of the European Parliament, the Council and the Commission." The purpose of COSAC, whose outcomes are non-binding, is to promote the exchange of information and best practices between national parliaments and the European Parliament and to organize interparliamentary conferences on certain topics such as the common foreign and security policy. The first COSAC meeting took place on 16 and 17 November 1989 in Paris.

Another form of interparliamentary conferences is the Interparliamentary Conference for the Common Foreign and Security Policy (CFSP) and the Common Security and Defence Policy (CSDP), which was established in 2012. ${ }^{138}$

\subsubsection{Other forms of interparliamentary cooperation}

As a response to the Eurozone crisis, Article 13 of the Treaty on Stability, Coordination and Governance in the Economic and Monetary Union (TSCG), or Fiscal Compact, now calls for the establishment of

a conference of representatives of the relevant committees of the European Parliament and representatives of the relevant committees of national parliaments in order to discuss budgetary policies and issues covered by [the Fiscal Compact].

135 European Parliament website, Conference of Speakers of EU Parliaments, available at: <www.europarl.europa.eu/webnp/cms/pid/8;jsessionid=039B36380637B5C28EB5148DC804063F> (last retrieved on 1 May 2016).

136 Ibid.

137 European Parliament website, Conference of Parliamentary Committees for Union Affairs (COSAC), available at: <www.europarl.europa.eu/webnp/cms/pid/9> (last retrieved on 1 May 2016); C. Hefftler, K. Gattermann, "Interparliamentary Cooperation in the European Union: Patterns, Problems and Potential", in: C. Hefftler, C. Neuhold, O. Rozenberg, J. Smith (eds.), The Palgrave Handbook of National Parliaments and the European Union, Palgrave Macmillan: United Kingdom, 2015, p. 96.

138 Ibid., p. 99. 
This resulted in the establishment of the Interparliamentary Conference on Economic and Financial Governance of the European Union in 2013. ${ }^{139}$ It is to meet twice a year in coordination with the European Semester cycle. ${ }^{140}$ The first meeting took place in October 2013 in Vilnius under the Lithuanian Presidency, with the objective of exerting "oversight over intergovernmental decisions in the area of economic and financial governance."141 In January 2014 and February 2015, the Interparliamentary Conference on Economic and Financial Governance was held within the framework of the European Parliamentary Week (EPW). ${ }^{142}$

The European Parliamentary Week was initiated by the European Parliament in January 2013 as a response to the European Semester (ES) and it brings together MEPs and national parliamentarians to discuss economic, budgetary and social issues in Brussels. ${ }^{143}$ It is linked to the European Semester and "will be maintained as one of the two pillars of the new Interparliamentary Conference on Economic and Financial Governance when the conference meets in the first half of each year." ${ }^{\prime 14}$ In 2015, the European Parliamentary Week took place from 3 to 4 February and it included (1) the Interparliamentary meeting on the European Semester Cycles 2014 and 2015 and (2) the Interparliamentary Conference on Economic and Financial Governance under Article 13 of the TSCG. ${ }^{145}$ The purpose of the first part of the EPW is for the European Parliament and the national parliaments to discuss the European Commission's annual growth survey (AGS) and other issues relating to the European Semester. ${ }^{146}$ It included "plenary sessions as well as three parallel interparliamentary committee meetings organised by the EP Committees on Economic and Monetary Affairs (ECON), on Employment and Social Affairs (EMPL) and on Budgets (BUDG)."147 During the second part of the meeting, which aimed to reinforce parliamentary cooperation in matters relating to the Fiscal Compact, the implementation of the latter and the social dimension of the Economic and Monetary Union (EMU) were discussed. ${ }^{148}$

139 Ibid.

140 V. Kreilinger, "The New Inter-Parliamentary Conference for Economic and Financial Governance", (2013) Policy Paper Notre Europe October 2013, p. 15.

141 Hefftler, Gatterman, supra note 137, p. 99.

142 Ibid.

143 European Parliament website, European Parliamentary Week 2016, available at: $<$ www.europarl.europa.eu/relnatparl/en/conferences/european-parliamentary-week.html> (last retrieved on 1 May 2016).

144 Kreilinger, supra note 140, p. 7.

145 European Parliament website, supra note 143.

146 Hefftler, Gatterman, supra note 137, p. 99.

147 European Parliament website, supra note 143.

148 Ibid. 


\subsubsection{IPEX}

Less of a form of interparliamentary cooperation and more of an instrument of the latter, IPEX is a website that was created in 2004, launched in 2006 and revised in 2011, which contains all the European legislative proposals and which allows national parliaments as well as the European Commission to upload all documents relating to the scrutiny process and subsidiarity checks. ${ }^{149}$ National parliaments - or the chambers thereof - have the possibility to upload icons to indicate the progress of their scrutiny process; the progress of a subsidiarity check, including any concerns with regards thereto; any information that they deem important to exchange with other chambers and reasoned opinions under the Early Warning Mechanism of Protocol $\mathrm{No}^{\circ} 2$ regarding a legislative proposal's compliance with the principle of subsidiarity. ${ }^{150}$

The issue with IPEX is, however, that many national parliaments merely upload an icon indicating one of the above responses, without uploading the relevant documents regarding, for example, the important information contained therein. It is only for reasoned opinions that the icons are almost always accompanied by a document. Moreover, even if national parliaments upload the relevant documents on IPEX, this is often done with some delay, which is especially problematic considering the eight-week time limit provided for by the Early Warning Mechanism. Another problem is the language of the documents uploaded, which is often only the official language of the respective national parliament, with the exception of reasoned opinions for which English translations typically exist. ${ }^{151}$

\subsubsection{Permanent representatives in Brussels}

In addition to the more formal channels of interparliamentary cooperation, all national parliaments have also established an office of permanent representatives in Brussels. Similar to the permanent representations of their governments, some of them are affiliated to the latter and others are not. They all have offices at the European Parliament's premises in Brussels in order to facilitate cooperation with the former on a day-to-day basis. ${ }^{152}$

149 V. Knutelska, “Cooperation among National Parliaments: An Effective Contribution to EU Legitimation?”, in B. Crum and J.E. Fossum, Practices of Interparliamentary Coordination in International Politics, the European Union and Beyond, ECPR Press: United Kingdom, 2013, p. 41.

150 Ibid., p. 42.

151 Ibid.

152 Ibid., pp. 37-38. 


\subsubsection{Legislative powers}

\subsubsection{Ordinary legislative procedure}

According to Article 14(1) TEU, the European Parliament exercises legislative power jointly with the Council. The Treaty of Lisbon transformed the co-decision procedure into the ordinary legislative procedure (OLP) and extended it to more legislative areas. Thus, in approximately $90 \%$ of cases, the European Parliament now acts on equal footing with the Council. ${ }^{153}$ As before, under the OLP, it is both the European Parliament and the Council who jointly adopt a Union act upon receiving a proposal from the Commission. ${ }^{154}$

Both the EP and the Council have a right of amendment (Articles 294(3)-(6) TFEU). In cases where parliamentary amendments are supported by the Commission, the Council must act unanimously to adopt a different version itself (Article 294(9) TFEU). If no consensus can be reached between the EP and the Council after the second reading, a conciliation committee is convened, consisting of the members of the Council and an equal amount of representatives from the EP (Article 294(10) TFEU). Throughout the legislative procedure, a so-called trilogue between representatives of the European Parliament, the Council and the European Commission takes places. The trilogue is a forum in which both the Council and the Parliament outline their respective positions in order to seek an agreement. Due to efficiency concerns, access to trilogue meetings is restricted to the respective delegations and their essential support staff. ${ }^{155}$ These meetings are liable to challenge democratic legitimacy because they lack both formality and transparency.

If the conciliation committee succeeds in finding the compromise with which they are charged, then the joint text must be approved by both the Council and the European Parliament respectively. Should either one refuse to do so, the proposed act is deemed not to have been adopted (Article 294(13) TFEU). Thus, both the EP and the Council hold a veto right within the context of the ordinary legislative procedure.

These two institutions, taken together, can be perceived as a bicameral legislature in the Union (albeit without a right of initiative), with the Council representing the Member States and the European Parliament representing the European citizens. ${ }^{156}$ The purpose

153 B. De Witte, A.H. Trechsel, D. Damjanovic, E. Hellquist, J. Hien, P. Ponzano, "Legislating after Lisbon New Opportunities for the European Parliament", (2010) Study Prepared in the Framework of the European Union Democracy Observatory (EUDO), Florence, p. 26.

154 Articles 289 and 294 TFEU.

155 European Parliament, "Codecision and Conciliation - A Guide to how the Parliament co-legislates under the Treaty of Lisbon”, (2012), available at: <www.europarl.europa.eu/code/information/guide_en.pdf > (last retrieved on 26 March 2014), p. 19.

156 S. Hix, The Political System of the European Union, $2^{\text {nd }}$ ed., Palgrave Macmillan: New York, 2005, p. 72. 
of both the co-decision and the ordinary legislative procedure is for both the representatives of the Member States and of the citizens to play a crucial part in the EU decision-making process, ${ }^{157}$ thereby establishing a legislature that is "democratically underpinned and legitimized" with "the power to exercise the highest law-making authority."158 This is manifested in the fact that legal acts that are adopted by the Council and the EP rank higher than rules that have been adopted by other Union institutions and bodies (see Section 3.5.1.5 on the EP and secondary legislation). ${ }^{159}$

\subsubsection{Right to initiative}

Even though the European Parliament does not have an explicit right to initiate legislation - since this right belongs exclusively to the Commission ${ }^{160}$ - it can, by a majority of its members, "request the Commission to submit any appropriate proposal on matters on which it considers that a Union act is required for the purpose of implementing the Treaties" (Article 225 TFEU). In case the Commission does not follow the EP's request, it must inform the latter of its reason for doing so. This is an extension to the pre-Lisbon rules, because the Commission is now legally obliged to justify its non-compliance with the EP's request. ${ }^{161}$

\subsubsection{Special legislative procedures}

The equal standing of the Council and Parliament under OLP does not exist in the context of special legislative procedures (Article 289(2) TFEU). These replace the procedures that were known pre-Lisbon as consultative, cooperation and assent procedures. As is indicated by their names, in these procedures it is the Council who constitutes the sole legislator, while parliamentary involvement is limited to consultation or approval, depending on which procedure is to be applied. While the TFEU provides for a detailed description of the ordinary legislative procedure in Article 294 thereof, there is no corresponding article for the legislative procedure. Instead, the rules for the latter are prescribed on an ad hoc basis by the respective legal provisions providing for their application. ${ }^{162}$

\subsubsection{Other forms of parliamentary involvement in decision-making}

There are also other forms of parliamentary involvement in the Union's legislative procedure, outside those that are mentioned here. If the Council wishes to adopt a legal act based on the so-called flexibility clause in accordance with Article 352 TFEU, it must obtain the

157 W. Voermans, "Is the European Legislator after Lisbon a Real Legislature?”, (2011) 17 The Brown Journal of World Affairs, p. 167.

158 Ibid., p. 168.

159 Ibid.

160 Article 17(2) TEU.

161 Kohler, supra note 109, p. 4.

162 Voermans, supra note 157, p. 165. 
consent of the European Parliament. This requirement is a new one; before the entry into force of the Treaty of Lisbon, the European Parliament merely had a consultation right while the Council had to act unanimously. Similarly, the consent of the EP is also needed if a certain amount of Member States want to proceed with enhanced cooperation under Article 329(1) TFEU, unless it concerns the Common Foreign and Security Policy (CFSP), in which case the Parliament is merely informed.

Furthermore, and in relation to treaty revisions, the powers of the Parliament have been increased by the Treaty of Lisbon. It may now propose treaty revisions in both the ordinary procedure for revision and the simplified procedure (Articles 48(2) and (6) TFEU respectively). Prior to the entry into force of the Treaty of Lisbon, this was a "long-standing request by the European Parliament which had been regularly rejected by the Member States." 163 The European Parliament also has a right to approve international agreements (Article 218(6) TFEU).

\subsubsection{The European Parliament and secondary legislation}

When discussing the European Parliament's legislative powers, it is also interesting to analyze its role with regard to the adoption of secondary legislation. Pre-Lisbon, such acts were known as comitology; post-Lisbon, comitology has been replaced by delegated acts and implementing acts. Comitology is a system whereby the Commission works in tandem with a committee of representatives of national governments that oversee the Commission. This procedure, under which the Council delegated some of its decision-making powers to the Commission, has existed since the genesis of the EEC. Because it was impossible for primary legislation to deal with every change of circumstances in each policy area, the Council, by means of a 'parent regulation', delegated the power to adopt more specific regulations to the Commission. Such delegation was conditional upon the Commission's cooperation with the committee of Member State representatives. ${ }^{164}$

Delegated acts are non-legislative acts that have been adopted by the Commission. They supplement or amend certain non-essential elements of the legislative act that delegates such power to the Commission (Article 290(1) TFEU). Both the Council and the European Parliament have the right to revoke said delegation (Article 290(2)(a) TFEU). A delegated act may only enter into force in cases where neither the Council nor the Parliament has objected (Article 290(2)(b) TFEU). Implementing acts, on the other hand, are measures adopted in order to implement legally binding Union acts. They are adopted by the Member States (Article 291(1) TFEU) or by the European Commission where imple-

163 J.C. Piris, The Lisbon Treaty - A Legal and Political Analysis, Cambridge University Press: Cambridge, 2010, p. 121.

164 P. Craig, G. De Burca, EU Law - Texts, Cases and Materials, $5^{\text {th }}$ ed., Oxford University Press: Oxford, 2011, p. 134. 
mentation is required on EU level in order to achieve uniform conditions thereof (Article 291(2) TFEU). ${ }^{165}$

It is also under Article 291 TFEU that comitology is retained. Regulation 182/2011 provides for two types of procedures. ${ }^{166}$ Under the advisory procedure, the Commission does not have to follow the committee's opinion (Article 4 of Regulation 182/2011). Under the examination procedure, it can only adopt the implementing measure if the committee delivers a positive opinion or (with some exceptions) no opinion. If the committee delivers a negative opinion, the measure cannot be adopted, even though it does not have to be referred back to the Council anymore as before (Article 5 of Regulation 182/2011). Moreover, the Regulation gives the Parliament and the Council the right to indicate to the Commission that its proposed implementing measure exceeds its implementing powers, as is provided for in the parent measure, where the latter was adopted as a measure under the ordinary legislative procedure. The Commission does not, however, have to withdraw the act after taking into account the EP and Council's views, but it merely has to inform them about whether it intends to maintain, amend or withdraw the proposed act. ${ }^{167}$

Articles 290 and 291 TFEU were intended to simplify the adoption of secondary legislation and render it more democratic by including the EP in the procedure. Both the Council and the European Parliament now have powers of control over delegated acts by the right to revoke the delegation or to veto the delegated act. This is an improvement for the role of the European Parliament with regard to delegated acts. What should be noted is, however, the fact that neither the Council nor the Parliament have a formal right to propose amendments to delegated acts. They can only prevent them from entering into force, but they are not able to change it to their likings. ${ }^{168}$

Moreover, the European Parliament still plays no role in the procedure under Article 291 TFEU. This is especially problematic because the distinction between delegated and implementing acts is very difficult to discern. Thus, while the Council will not have to fear much loss where an act is categorized as an implementing act - as representatives of the Member States will still be involved -, the Parliament will most likely push for acts to be categorized as delegated acts in order for it to be able to exercise its veto right. ${ }^{169}$

165 In justified specific cases and in the cases provided for in Articles 24 and 26 TEU, such implementing powers belong to the Council.

166 Regulation (EU) No. 182/2011 of the EP and the Council of 16 February 2011 laying down the rules and general principles concerning mechanisms for control by Member States of the Commission's exercise of implementing powers [2011] OJ L55/13.

167 Article 11 of Regulation 182/2011.

168 Craig, De Burca, supra note 164, p. 138.

169 P. Craig, "Delegated Acts, Implementing Acts and the New Comitology Regulation", (2011) 36 European Law Review, p. 675. 


\subsubsection{Budgetary powers}

Article 14(1) TEU lays down the EP's budgetary powers, which it again exercises jointly with the Council. This power is arguably the most important power of the European Parliament - without its approval there can neither be a budget nor can the Commission's expenses be discharged. ${ }^{170}$ Article 310 TFEU provides that the "Union's annual budget shall be established by the European Parliament and the Council in accordance with article 314 ", which lays down the exact procedure. What is new under the Treaty of Lisbon is that the distinction between the so-called 'compulsory expenditure' and 'non-compulsory expenditure' was abolished. Pre-Lisbon, the Parliament only had the last word with regard to the latter, with the final say on the former belonging to the Council as they were seen as fixed by the Treaties and hence not subjected to the budgetary procedure. ${ }^{171}$ Under the new procedure, both the EP and the Council now co-decide on all of the Union's expenditure, again putting the two on an equal footing. ${ }^{172}$

The Union's annual budget is part of a multiannual financial framework of at least five years, which ensures that "Union expenditure develops in an orderly manner and within the limits of its own resources" (Article 312(1) TFEU). The multiannual framework is to be adopted by the Council following the consent of the European Parliament (Article 312(2) TFEU) and determines the amounts of the annual ceilings on commitment appropriations by category of expenditure and of the annual ceiling on payment appropriations (Article 312(3) TFEU). Thus, the European Parliament has the right to consent to the multiannual financial framework, as well as the power to veto the budgetary procedure for the annual budget (Article 314 TFEU).

Under this procedure, it is the Commission which submits a draft budget with an estimation of the expenditure for the following year to both the European Parliament and to the Council. The Council then adopts its position, which is forwarded to the EP. The budget is deemed to be adopted if the EP approves the Council's position or if does not take any decision within 42 days. If the Parliament adopts amendments with a majority of its component members, a conciliation committee is convened, unless the Council approves the parliamentary amendments within ten days.

The conciliation committee, which is composed of the members of the Council and an equal number of EP representatives, then has 21 days to reach agreement on a joint text. Should, within 14 days, both institutions adopt the joint text or should one or both fail to adopt a decision, the budget is deemed to be definitely adopted. If either institution rejects the text while the other does not act or if both reject the text, a new draft budget must be submitted by the Commission. The same applies if the EP rejects the joint text,

170 Kohler, supra note 109, pp. 5-6.

171 Corbett, Jacobs, Shackleton, supra note 7, p. 274.

172 Piris, supra note 163, p. 120. 
even when it is approved by the Council. If the compromise is approved by Parliament but rejected by the Council, the former can, within 14 days, decide with a 3/5 majority to confirm its amendments that were adopted at first reading. Amendments not confirmed are retained in their form as they are found in the joint text and the budget is deemed to be definitely adopted in this case as is pronounced by the President of the Parlialment (Article 314 TFEU). In any case, it is the European Parliament that has the final say over the adoption of the budget. There is no possibility for the Council to override a parliamentary veto (Article $314(7)(\mathrm{c})$ ).

\subsubsection{Scrutiny powers}

The third type of power that the European Parliament possesses is the power to scrutinize the activities of the executive. Article 14(1) TEU states that the EP "shall exercise functions of political control and consultation as laid down in the Treaties." Traditionally, such powers of political control are directed towards the European Commission as the executive of the EU, which is in turn accountable to Parliament. ${ }^{173}$ The following part will examine the EP's oversight functions vis-à-vis not only the Commission but also the Council of Ministers, the European Council, the European Central Bank and the Court of Auditors.

\subsubsection{The European Parliament and the Commission}

The relationship between the EP and the Commission is regulated by the Treaties and the Framework Agreement on relations between the European Parliament and the Commission. As per Article 17(7) TEU, the Commission, as a body, must be voted into office by the EP. Whereas it is the Council, in accordance with the Commission President, who adopts the list of possible members of the Commission, it is still the EP which must approve the Commission as a whole, before it can be appointed by the European Council. Moreover, the candidate for the President of the Commission is elected by the EP on a proposal of the European Council, which takes "into account the elections to the European Parliament", "after having held the appropriate consultations" (Article 17(7) TEU). If the candidate is not elected by the majority of members of parliament, the European Council must propose a new candidate to the Parliament. ${ }^{174}$ Thus, the political composition of Parliament after its direct elections will have a considerable influence on the decision by the European Council as to which candidate it should nominate. ${ }^{175}$ And yet, it is important to note that

173 L. Verhey, "Fostering Executive Accountability in the EU: A Key Issue”, in J. Wouters, L. Verhey, P. Kiiver (eds.), European Constitutionalism beyond Lisbon, Intersentia: Antwerp, 2009, p. 242; Von Bogdandy, supra note 80 , p. 38.

174 Article 17(7) TEU.

175 Shackleton, supra note 20, p. 131. 
the EP does not have the right to elect a Commission President on its own account. The nominee will still be matter of the preferences of the Member States. ${ }^{176}$

The Commission, once in office, is then, as a body, responsible to the European Parliament (Article 17(8) TEU). The EP may vote on a motion of censure against the Commission in accordance with the procedure that is laid down in Article 234 TFEU, which leads to the resignation of the Commission en bloc. And while Parliament does not have the power to dismiss individual Commissioners (this power belongs exclusively to the President of the Commission under Article 17(6) TEU), it nevertheless remains "an important forum to which some European actors, especially the European Commission, must give account." ${ }^{\text {"177 }}$ In a similar vein, the term of the Commission was aligned to the parliamentary term of five years in the Treaty of Maastricht in order to facilitate and increase parliamentary scrutiny powers over the Commission. ${ }^{178}$

An instance in which Parliament demonstrated its will to use its political powers against the Commission was the appointment of the Barroso Commission in 2004. Unhappy with some of the nominees for Commissioners, the European Parliament made it clear that it would not vote the College of Commissioners into office, unless some changes were made thereto. Faced with this parliamentary opposition, Commission President Barroso was forced to replace the Italian and Latvian nominees after consultation with national governments as well to allocate a new portfolio to the Hungarian nominee in order to secure Parliament's vote of investiture. ${ }^{179}$ This was the first time that, even without the legal power to dismiss or reject individual Commissioners, the European Parliament was able to influence the composition of and the allocation of portfolios within the Commission. ${ }^{180}$ It emphasized the fact that the Commission was a political executive, which is dependent on parliamentary confidence in order to take office. In that regard, the Commission and the Parliament have a similar relationship to national executives and elected parliaments that is present at the national level. ${ }^{181}$

The EP has, moreover, the right to discharge the Commission with regard to the latter's implementation of the budget, upon receiving the recommendation of the Council. In order to do so, it may ask the Commission to give evidence with regard to the execution of expenditure or the operation of financial control systems. ${ }^{182}$ A refusal to discharge the Commission would considerably weaken the Commission's political position and could

176 Verhey, supra note 173, pp. 242-243.

177 Ibid., p. 242.

178 Corbett, Jacobs, Shackleton, supra note 7, p. 295.

179 Ibid.

180 Meny, supra note 17, p. 191.

181 Corbett, Jacobs, Shackleton, supra note 7, p. 296.

182 Article 319 TFEU. 
possibly lead to either the resignation by the Commission or, alternatively, a motion of censure by Parliament to remove the Commission. ${ }^{183}$

This power to dismiss the Commission should not be underestimated, as was demonstrated at the end of the 1990s with regards to the Santer Commission. In January 1999, allegations of fraud, nepotism and financial mismanagement by the Commission were raised. A 'Committee of Independent Experts' was appointed in order to investigate the Commission, which in turn agreed to accept the findings of the committee as well as to act upon them. After a motion of censure had failed in the European Parliament, the committee finally freed the Commission of the fraud allegations in March 1999, but found serious mismanagement to be present throughout the institution. ${ }^{184}$ In its first report of March 1999, it stated that there was "a growing reluctance among the members of hierarchy to acknowledge their responsibility" and that it was "becoming difficult to find anyone who has even the slightest sense of responsibility", which it considered to be the "ultimate manifestation of democracy." ${ }^{\prime 85}$ Following this report, it became clear in Parliament that a majority would support a motion of censure against the Commission. In light of these developments, the Santer Commission decided to collectively resign. ${ }^{186}$

The resignation of the Santer Commission is the second famous example of a change in the institutional balance and the Parliament-Commission relationship. It emphasized Parliament's power of censure against the Commission, even when not exercised legally, and made it clear that a lack of individual accountability did not mean that members of the Commission were politically non-accountable.

Another means of parliamentary control over the Commission is the right to ask questions to the latter. Under Article $230 \mathrm{TFEU}$, the Commission is under an obligation to "reply orally or in writing to questions put to it by the European Parliament or its Members." This procedure gives the EP the possibility to ask for specific information from the Commission or for its opinion on specific matters. ${ }^{187}$ There are three ways in which the Parliament can pose questions to the Commission. Rule 117 of the Rules of Procedure of the European Parliament (Rules of Procedure) stipulates that any MEP may put questions for written answer to the Commission. Secondly, each part-session of the Parliament question time with the Commission is held, during which any MEP may ask questions to the Commission, which answer the questions orally (Rule 116 of the Rules of Procedure). Questions that could not be answered within the ninety minutes are subsequently answered

183 Corbett, Jacobs, Shackleton, supra note 7, p. 288.

184 Ibid., p. 289.

185 Committee of Independent Experts, First Report on Allegations regarding Fraud, Mismanagement and Nepotism in the European Commission, 15 March 1999, available at: <www.europarl.europa.eu/experts/ pdf/reporten.pdf> (last retrieved on 22 March 2014), p. 144.

186 Corbett, Jacobs, Shackleton, supra note 7, p. 289.

187 C. Syrier, The Investigative Function of the European Parliament: Holding the EU Executive to Account by Conducting Investigations, Wolf Legal Publishers: The Netherlands, 2013, p. 198. 
in writing. ${ }^{188}$ Thirdly, according to Rule 115 of the Rules of Procedure, a parliamentary committee, a political group or at least 40 MEPs may put questions to the Commission with the request that they are placed on the Parliament's agenda. In addition, the Framework agreements provides for a periodical 'Question Hour' with the President of the Commission and the Commission, during which questions are posed spontaneously by political group leaders. In a second instance, questions are posed on an agreed policy topic, but without any prepared questions. ${ }^{189}$ Furthermore, some standing committees make regular use of question time with the Commission in their committee in a more informal manner, allowing for follow-up questions. ${ }^{190}$ Another important means of holding the Commission accountable for its actions is the practice that individual Commissioners (as well as members of the Council, directors of EU agencies, the President of the ECB and both national and Union civil servants for that matter) be present at the standing committees' meetings. ${ }^{191}$

Even though there is no obligation under the Treaties for the Commission to appear before the Parliament in its plenary sittings or in the parliamentary committees' meetings at the latter's request, the Framework Agreement states that such requests have priority over other events and invitations. ${ }^{192}$

The EP may also set up a temporary committee of inquiry in order to investigate alleged instances of contravention and maladministration in the implementation of Union law, unless the case is already pending before the ECJ. ${ }^{193}$ Since this right was formally introduced by the Treaty of Maastricht in 1993, three temporary committees of inquiries have hitherto been established. ${ }^{194}$ According to Syrier, these "committees of inquiry of the European Parliament have rather limited powers of investigation." 195 One of the reasons for this is the fact that they are dependent on the Commission to cooperate and to grant them access to the relevant documents. Another reason is the restricted scope of the right of inquiry. ${ }^{196}$ One way to circumvent the restricted scope of the right to establish temporary committees of inquiry is the establishment of temporary special committees (Rule 184 of the Rules of Procedure), of which twelve have been established since $1993 .{ }^{197}$ Overall, Syrier concludes that the EP "has proved able to use its right of inquiry as a means of holding the Commission to account for its actions." However, as it is solely focused on the Commission, other

\footnotetext{
188 Ibid.

189 Ibid.

190 Ibid.

191 Ibid., p. 191.

192 Ibid., p. 198.

193 Article 226 TFEU.

194 Syrier, supra note 187, p. 54.

195 Ibid., p. 123.

196 Ibid.

197 Ibid., p. 187.
} 
executive actors such as the Council or the individual Member States are able to escape responsibility, even where they are blameworthy. ${ }^{198}$

The EP can also elect a European Ombudsman under Article 228 TFEU, whose task is to conduct inquiries into practices of maladministration by the Union institutions. There also exists the possibility for Union citizens - or any natural or legal person residing or having its registered office in a Member State - to petition the EP on matters that fall within the scope of EU law and that directly affect them (Article 227 TFEU).

\subsubsection{The European Parliament and the Council of Ministers}

It is not only the European Commission that holds executive power in the EU, but to a limited extent so too does the Council of Ministers, which sets guidelines for the Commission, oversees the latter's implementation thereof and delegates implementing powers to the Commission. Under Article 291 TFEU, some implementing powers are reserved to the Council itself. Thus the question must also be asked: what kind of scrutiny powers does the EP hold over the Council when the latter performs such tasks? ${ }^{199}$

The answer is that the EP's scrutiny powers over the Council are, in practice, very weak. The Council informs the EP of its activities on a regular basis. ${ }^{200}$ It may be asked by Parliament to make a statement in plenary in relation to important issues (Article 230 TFEU) and oral and written questions may be submitted to it (Rules 115 and 117 of the Rules of Procedure). Moreover, a practice has developed whereby the Council engages in debates with the EP. ${ }^{201}$ The President of the Council will also be invited to present and discuss the Presidency programme with the Parliament in plenary at the beginning and the end of each presidency. ${ }^{202}$

Unlike the European Commission, the Council is under no obligation to respond to parliamentary questions. ${ }^{203}$ It does, however, have some information obligations $v i s-\grave{a}$-vis the European Parliament. Article 121(2) TFEU states that the Council must inform the EP of any recommendation on broad guidelines of the economic policies (BEPG) of the Member States and of the Union. The President of the Council and the Commission must report to the EP on the results of multilateral surveillance and the former may be invited to appear before the competent standing committee of the Parliament, if the recommendation has been made public (Article 121(5) TFEU). Article 126(11) TFEU requires the President of the Council to inform the Parliament of any measures taken against a Member State within the context of the excessive deficit procedure.

198 Ibid., pp. 125-126.

199 Verhey, supra note 173, p. 243.

200 Syrier, supra note 187, p. 200.

201 Ibid.

202 Corbett, Jacobs, Shackleton, supra note 7, p. 315.

203 Syrier, supra note 187, p. 201. 
However, it remains difficult for the European Parliament to hold the Council and its President to account for its actions. ${ }^{204}$ It does not have the power to sanction the Council by dismissing the Council or the members of the Council, as the latter is composed of ministerial level representatives of the Member States. Thus, the individual national ministers are respectively accountable to their own national parliaments. This link was emphasized by the Treaty of Lisbon, which strengthened the role of national parliaments in the EU decision-making process through Article $12 \mathrm{TEU}$, Protocol $\mathrm{No}^{\circ} 1$ on the role of national parliaments in the European Union and Protocol $\mathrm{No}^{\circ} 2$ on the application of the principles of subsidiarity and proportionality. ${ }^{205}$

However, although it seems appropriate for the national parliaments to hold their national governments to account for their actions within the Council, there is no institution to which the Council is accountable as a whole, as it is composed of the 28 governments of the Member States. Taking this into consideration, the question itself is whether or not the Council should be responsible vis-à-vis the European Parliament, ${ }^{206}$ as for now the parliamentary oversight functions over the Council remain limited without the possibility of sanctioning the latter when the EP is not satisfied with the exercise of its executive powers. The argument against such an accountability relationship between the Council and the EP would be, however, that they both function as something similar to two chambers of a (federal) parliament, with the Council constituting the upper chamber, representing the Member States, and the European Parliament constituting the lower chamber, which is directly elected by and which represents the citizens of the EU.

\subsubsection{The European Parliament and the European Council}

The Treaty of Lisbon, and the impact of the Euro crisis, has turned the European Council into one of the key players within the European institutions and in the EU decision-making process. ${ }^{207}$ As with the Council of Ministers, the relationship between the European Parliament and the European Council is not a strong one with regard to the former's scrutiny rights.

Article 230 TFEU stipulates that the European Council may be heard by the EP, which may also submit questions for written answers to the President of the European Council (Rule 117 of the European Parliament Rules of Procedure). Article 15(6)(d) TEU and Article 5 of the European Council Rules of Procedure provide that after each of its meetings, the President of the European Council must present a report to the Parliament on its priorities and on the results achieved during the meeting. In practice this means that the

204 Ibid., p. 127.

205 Verhey, supra note 173, pp. 243-244.

206 Syrier, supra note 187, p. 127.

207 C. Hefftler, W. Wessels, “The Democratic Legitimacy of the EU's Economic Governance and National Parliaments", (2013) IAI Working Papers 13|13, p. 4. 
President must appear before the Parliament after each European Council Summit and to inform it of the summit's outcome. ${ }^{208}$ In order to fulfill this obligation, he must merely appear at the plenary session. After having made the opening statement, the President of the European Council is not obliged to remain in the plenary session to listen to and give answers to the questions by the EP, and he may leave. ${ }^{209}$ Neither is he obliged to appear before a specialized standing committee, which rarely occurs in practice. Thus, he does not have to expose himself to close scrutiny, ${ }^{210}$ and as MEPs are not allowed to repeat their question, he cannot easily be pressured into adequately replying to parliamentary questions. ${ }^{211}$ But even if parliamentary scrutiny towards the European Council President were to be stricter, it would still remain difficult to hold him accountable for the substance of the decisions made by the European Council. As President, he does not control the members of the European Council and cannot make binding promises as to future decisions by the European Council as the latter is not a collegiate body that is subject to collective accountability. Overall, the questioning of the European Council President by the MEPs is of a more "ceremonial character", which gives the President the opportunity to "showcase its plans or, respectively, its achievements." ${ }^{212}$ The EP has nothing but an information right, which places it in a rather weak position vis-à-vis the European Council.

This does not mean that there is no information flow between the European Council and the European Parliament at all. According to van den Steeg there exists a practice for the provision of information outside of the plenary sessions. ${ }^{213}$ At least once during the semester, a general discussion takes place within an informal meeting between the Committee of Presidents of the Parliament and the political groups and the President of the European Council. This general discussion is a possibility for "accountability behind closed doors", which may positively affect the public debate with the European Council President in plenary. ${ }^{214}$ In the opposite direction, the President of the EP may be invited to be heard by the European Council at the beginning of their meetings and make known the Parliament's position on the subjects that are to be discussed (Article 235(2) TFEU and Article 4(2) of the European Council Rules of Procedure). This gives both parties the opportunity to familiarize themselves with each other's positions.

208 Syrier, supra note 187, p. 200.

209 M. Van Den Steeg, "Public Accountability in the European Union: Is the European Parliament able to hold the European Council accountable?”, (2009) 13 European Integration Online Papers, p. 5.

210 Ibid., p. 5.

211 Ibid.

212 B. Crum, "Accountability and Personalization of the European Council Presidency", (2009) 31 Journal of European Integration, p. 692.

213 Van Den Steeg, supra note 209, p. 7.

214 Ibid. 
Nevertheless, the European Parliament lacks any substantial means of sanctioning the European Council, which in turn does not have to fully disclose its actions to the MEPs. ${ }^{215}$ As with the Council of Ministers, the EP cannot dismiss the European Council as it is composed of the Heads of States or Governments of the EU Member States, who are only accountable to their national parliaments. The same issue that was mentioned above with regard to the Council of Ministers is also applicable to the European Council: while the national parliaments exert political control over the individual Heads of State or Government, such control remains fragmented as there is no holistic oversight over the European Council as an institution. ${ }^{216}$ Instead, the EP remains a passive observer without the possibility to impose sanctions on the European Council or to exert democratic control over the latter where it finds the European Council's actions to be unacceptable. Overall, van den Steegen concludes that the power of the EP to scrutinize the European Council "depends largely on the benevolence of the Presidency." ${ }^{217}$ However, even this is disputable because even the most benevolent President would not necessarily solve the problem as he, even though he has the task of facilitating cohesion and consensus within the European Council (Article 15(6) TFEU), has no say over what the other members say or do.

\subsubsection{The European Parliament and the European Central Bank}

According to its own resolution, the European Parliament is of the opinion that it is the most appropriate institution to exercise democratic control over the European Central Bank because it is the only directly elected Union institution. ${ }^{218}$ It has a consultation right in relation to the appointment of the President, Vice-President and members of the Executive Board of the ECB, who are appointed by the European Council on a recommendation from the Council, but its consent is not required (Article 283(2) TFEU). The President of the ECB must also present the annual report on the activities of the European System of Central Banks (ESCB) and the monetary policy to the European Parliament, following which the latter can organize a debate about the report (Article 284(3) TFEU). The President and the other members of the Executive Board may also be heard by the competent committees of the EP, either at the request of the Parliament or on their own initiative (Article 284(3) TFEU). In addition, the President of the ECB appears four times a year before the EP's Committee on Economic and Monetary Affairs in order to report on the ECB's monetary policy and its other tasks. ${ }^{219}$ While this is not a legal obligation, the agreement - made by the first ECB President Wim Duisenberg - has nevertheless been

215 Crum, supra note 212, p. 692.

216 Van Den Steeg, supra note 209, p. 2.

217 Ibid., p. 17.

218 European Parliament, Resolution of 2 April 1998 on democratic accountability in the third phase of EMU [1998] OJ C138/177.

219 C. Fasone, "The Struggle of the European Parliament to Participate in the New Economic Governance", (2012) EUI Working Papers RSCAS 2012/45, p. 11. 
adhered to by succeeding Presidents. ${ }^{220}$ There are also informal discussions between the members of parliament and the ECB representatives, who by convention also reply to written questions submitted by the former. ${ }^{221}$

It should be noted at this point that the high degree of independence that the ECB enjoys is an important element of its legitimacy, which it derives not from direct elections but as a result of its technical expertise. ${ }^{222}$ It is generally agreed that the primary objective of the ECB, namely maintaining price stability (Article 127(1) TFEU and Article 2 of the ECB Statute), can only be achieved through political independence. Political actors are deemed incapable of maintaining price stability because they are, by their very nature, influenced by political considerations and dependent on their voters, which is why they are more likely to take on an inflationary path in order to increase economic activities in the country, if this would lead to more popularity among voters. ${ }^{223}$ Monetary actions generally enjoy more credibility if they are taken by an independent agent, whose preferences can differ from those of the principal. ${ }^{224}$ For that reason, it can be argued that a high degree of accountability of the ECB towards the EP is, in fact, neither required nor desirable.

\subsubsection{Powers of the European Parliament in the EMU}

While the EP's powers have steadily increased with each Treaty amendment, this does not hold true in relation to the Economic and Monetary Union (EMU). Here, the Parliament has very little (if any) power at all. The ordinary legislative procedure, under which the EP has the most power as a co-legislator, is only applicable in very limited circumstances, namely Article 121(6) TFEU on the procedural aspects of the multilateral surveillance procedures, Article 129(3) TFEU for amending certain provisions of the ESCB and the ECB Statute and Article 133 TFEU on currency law. In all other matters, the European Parliament merely holds a consultation or information power and where the Treaty provisions concern the exclusive powers of the Eurozone, the EP holds neither. ${ }^{225}$

The role of the European Parliament was even further marginalized during the management of the Eurozone crisis, and not increased as one might have expected. This is due to the fact that some of the crisis response measures were adopted outside of the EU law framework, most notably through the European Stability Mechanism (ESM) and the Treaty

220 Syrier, supra note 187, p. 202.

221 Ibid.

222 N. Jabko, "Democracy in the Age of the Euro", (2003) 10 Journal of European Public Policy, p. 713.

223 R. Lastra, "Central Banking after the Crisis", (2010) 13 International Finance, p. 328.

224 S. Bredt, "Prospects and Limits of Democratic Governance in the EU”, (2011) 17 European Law Journal, p. 42 .

225 A. Maurer, "From EMU to DEMU: The Democratic Legitimacy of the EU and the European Parliament", (2013) IAI Working Papers 13|11, p. 5. 
on Stability, Coordination and Governance in the Economic and Monetary Union (TSCG). The ESM Treaty is an intergovernmental treaty between the members of the euro area, which establishes a permanent system of financial assistance between the Member States of the euro area. The TSCG is an intergovernmental treaty between 25 EU Member States (the only Member States to opt out were the United Kingdom and the Czech Republic; Croatia was not a member of the EU at that time), which aims to strengthen fiscal discipline in the EU. These two treaties are "complementary in fostering fiscal responsibility and solidarity within the economic and monetary union." 226

The fact that both treaties were concluded outside of the EU law framework makes it possible for the governments of the Member States to govern the decision-making process without having to take into account either EU law or the EU institutions, including the EP. Because both treaties are international agreements, there is no obligation to consult the European Parliament in their adoption. Consequently, the EP played no role in the adoption of the ESM Treaty. ${ }^{227}$ Neither is it mentioned in the text of the Treaty. In the negotiation process behind the TSCG, however, four representatives of the EP were allowed to participate, who then reported to the EP Committees on Constitutional Affairs and on Economic and Monetary Affairs and to the plenary session. ${ }^{228}$

Moreover, the European Parliament does not have the power to control decisions that have been taken under these treaties as the signatory states are not acting under EU law. As a consequence, the EP remains a "passive observer", which is only informed of the results of the European Council meetings and the Euro group summits, ${ }^{229}$ but which cannot exert any form of political control over the latter. In addition, neither the ESM nor the TSCG is dependent on the EU's budget, over which the EP has a veto power. Thus, they fall outside the scope of the Parliament's budgetary powers. Instead, the task of scrutinizing Eurogroup decisions on financial assistance falls to the national parliaments, ${ }^{230}$ thereby fully undermining the Parliament's role as the budgetary arm of the Union.

Thus, by leaving the framework of the EU Treaties, the Heads of States or Governments of the Eurozone Member States reinforce cooperation amongst themselves while escaping the control of the European Parliament, which lacks "a uniform or coordinated, reliable control mechanism whereby parliamentary oversight is combined with the possibility of political and legal sanctions against the decision-makers of the European Council, its President and the Eurogroup." ${ }^{231}$ It is, at best, only informed of their decisions but it has

226 Treaty establishing the European Stability Mechanism of 2 February 2012, Recital 5.

227 C. Fasone, "European Economic Governance and Parliamentary Representation. What Place for the European Parliament?”, (2014) 20 European Law Journal, p. 172.

228 Ibid.

229 Maurer, supra note 225, p. 3.

230 Ibid., p. 1.

231 Ibid., p. 3. 
no participation rights therein. ${ }^{232}$ Overall, the conclusion of intergovernmental treaties during the crisis has led to a situation whereby the legislative and democratic safeguards of the EU legal order have been being undermined.

\subsection{CONCLUding REMARKS}

In democratic systems, parliaments are considered to be the basis and symbol of democratic legitimacy, representing the national citizens and as a body that acts on their behalf. ${ }^{233}$ In the European Union, this function is divided between the national parliaments of the Member States and the European Parliament, which exercises crucial budgetary, legislative and supervisory powers at EU level. At the genesis of what is now known as the EU, democratic legitimacy was simply based on the acquiescence of the Member States. It was believed that the mere fact that the governments of the Member States could consent to or block supranational decisions was sufficient, as they themselves enjoyed legitimacy from the citizens at the national level. Consequently the question could be asked: why would it not be sufficient to rely solely on the Council and the European Council for EU democratic legitimacy? After all, they too enjoy legitimacy by being elected, either directly or indirectly, and by being accountable to the citizens through the national parliaments in their respective Member States. The reason for that are manifold but put simply, the use of QMV has distorted the democratic control of national parliaments on the respective ministers and, moreover, it is the European Commission which holds crucial powers in the EU decision-making process and over the direction of EU policies, thus rendering parliamentary control at EU level unavoidable. ${ }^{234}$

It is for that reason that the powers of the EP have been incrementally increased as a result of subsequent treaty reforms. The powers lost by the national parliaments were supposed to be compensated by an increase in the powers of the European Parliament. The Treaty of Lisbon did this by extending the ordinary legislative procedure to more legislative areas, enhancing the EP's powers of appointment and control over the Commission and putting it on an equal footing with the Council in relation to the budgetary procedure. It also replaced comitology by a system of delegated and implementing acts, which are less liable to undermine the EP's legislative powers because it provides for parliamentary involvement, at least in the context of delegated acts. This does not mean, however, that the European Parliament has replaced national parliaments as the source of democratic legitimacy in the EU. First of all, there are important parliamentary powers which do not

232 Fasone, supra note 227, p. 165.

233 W. Wessels, U. Diedrichs, "A New Kind of Legitimacy for a New Kind of Parliament - The Evolution of the European Parliament”, (1997) 1 European Integration Online Papers, p. 2.

234 Menon, Peet, supra note 8, p. 3. 
exist with regard to the European Parliament. It still does not have a right of initiative as is the case for the majority of national parliaments, as such a right belongs exclusively to the Commission. And even though the Commission President needs parliamentary approval in order to take office, the choice of candidate ultimately rests with the Member States. The EP neither holds oversight powers over the Council of Ministers nor over the European Council, despite the fact that both institutions have considerable powers and impact in the EU decision-making process, which has become heightened after the crisis. It is still national parliaments that are in charge of the latter, albeit only on an individual level and not against the respective institutions as a collective whole.

In general, it can be said that the European Parliament and the national parliaments of the Member States fulfill - or should fulfill - their representative and accountability functions in a complementary manner. ${ }^{235}$ This is also reflected in the text of the Treaty of Lisbon, which not only strengthened the position of the European Parliament but also that of the national parliaments. It also codifies the principle of EU dual legitimacy. The principle of EU dual legitimacy is enshrined in Article 10(2) TEU. Article 10(1) TEU states that the EU is built upon representative democracy. Article 10(2) TEU specifies that EU citizens are

directly represented at Union level in the European Parliament. Member States are represented in the European Council by their Heads of State or Government and in the Council by their governments, themselves democratically accountable either to their national Parliaments, or to their citizens.

This is a reflection of the belief that the only way to democratize the EU is by way of parliamentarization, with elections providing "two lines of democratic legitimation."236

235 According to the FCC, this does not mean, however, that they can be considered equal. Instead, the national parliaments are the primary source of EU democratic legitimacy and the EP is merely supplementary. See: D. Jancic, "Caveats from Karlsruhe and Berlin: Whither Democracy after Lisbon?", (2010) 16 Columbia Journal of European Law, pp. 337-383.

236 Von Bogdandy, supra note 13, p. 326. 



\section{The German Bundestag}

\subsection{INTRODUCTION}

The last chapter explained the relationship between the European Parliament and national parliaments in the EU, including how they have adapted to the European integration process over time and what roles they have now been accorded under the Treaty of Lisbon. It looked at the powers given to both the European Parliament and the national parliaments of the Member States under EU primary law, which with regard to the latter are the same for all 28 national parliaments. National parliaments, however, are also accorded powers in EU affairs under their respective domestic constitutional orders, which differ from Member State to Member State. These mainly relate to the second sentence of Article 10(2) TEU, which states that

Member States are represented in the European Council by their Heads of State or Government and in the Council by their governments, themselves democratically accountable either to their national Parliaments, or to their citizens.

This democratic accountability relationship between the national government and their national parliament can take different forms depending on what is prescribed in national constitutional law and it can therefore also differ in terms of the degree of control and influence that national parliaments are able to exert over their governmental representatives in both the Council and European Council. As a general notion, however, national parliaments constitute an important means of indirect democratic control irrespective of such differences; it is also their involvement in EU matters that prevents the EU from turning into an "unaccountable technocracy", irrespective of how weak or strong their control over policy outcomes may be. ${ }^{1}$

The following two chapters will take a closer look at the national parliaments of the Member States and the role that they fulfill in a system of dual representative democracy in the EU. They will not deal with the alleged problem of 'de-parliamentarization' or of the 'decline of national parliaments' in EU-decision making. 'They will instead focus on

1 See: A. Moravcsik, "In Defence of the 'Democratic Deficit': Reassessing Legitimacy in the European Union", (2002) 40 Journal of Common Market Studies, pp. 611-612.

2 See, for example: K. Auel, "De-Parliamentatisation Re-considered - Domestic Parliamentary Representation in EU Affairs", (2012) Paper prepared for the Annual Meeting of the American Political Science Association (APSA), New Orleans, September 2012; T. Raunio, "National Parliaments and European Integration - What We Know and What We Should Know", (2009) ARENA Working Paper No. 02; T. Raunio, S. Hix, "Back- 
the ability of individual national parliaments to control and hold accountable their national governments when the latter take decisions at the EU level; as the focus is on the national parliaments' relationship with their own government, their ability to scrutinize actions of EU institutions will not be dealt with. The following chapter in particular will consider the role of the German Bundestag in more detail, while Chapter 5 will consider the role of the Irish Dáil Éireann. Germany was chosen as a sample parliament due to its strong role during the crisis at the EU level but also due its strong role vis-à-vis the German government on domestic matters. The evolution of its powers during the crisis is moreover interesting insofar as much of it is owed to the German Federal Constitutional Court, the powerful Bundesverfassungsgericht (BVerfG). It will be shown that the German Court has played a vital role in strengthening the powers of parliament as the legitimizing organ of decisions by invoking the principle of democracy.

The first part of the chapter will briefly consider the theoretical framework of the different instruments of control that are available to national parliaments under their domestic constitutional laws and that can be used to hold government accountable for its actions (Section 4.2). The second part will then consider the powers of the German Bundestag in doing so and how this has been used over the last few years. Section 4.3.1 deals with its right to information. Section 4.3.2 deals with parliaments' power to influence the German government. Section 4.3.4 considers its powers to sanction the latter in the case of misconduct. Lastly, the budgetary power of the Bundestag as a means of control will be discussed in light of the judgments of the Bundesverfassungsgericht, before making some brief conclusions.

\subsection{Conceptualizing NATIONAL PARLiamentary CONTROL IN THE EU}

\subsubsection{Powers of national parliaments entrenched in domestic law}

In addition to those powers that have been given to national parliaments under European Union law, there are also the rights and obligations accorded to them under their respective national (constitutional) laws. By way of contrast to the powers given to national parliaments under EU primary law, the degree to which they are able to participate in EU affairs under domestic law varies greatly depending on the constitutional and legal setting of the Member State concerned. ${ }^{3}$ They mostly relate to the powers of a national parliament to hold its government accountable when the latter acts at EU level. This is often considered

benchers Lean to Fight Back: European Integration and Parliamentary Government”, (2000) 23 West European Politics, pp. 142-168.

3 O. Höing, "Differentiation of Parliamentary Powers - The German Constitutional Court and the German Bundestag Within the Financial Crisis”, (2012) OPAL Online Paper Series | 9/12, p. 11. 
to the 'traditional role' of national parliaments in the EU, as opposed to their direct participation at EU level that was described above. ${ }^{4}$ This traditional role of national parliaments in EU affairs predominantly relies on the conceptual relationship between parliament and government in a democratic system that has often been expressed in terms of the principalagent theory, ${ }^{5}$ which was further explained in Chapter 2. The different instruments of control that are available to national parliaments under their domestic constitutional laws to hold government to account will be described in the following section.

\subsubsection{Instruments of parliamentary control}

The instruments that are the focus of this chapter and the following chapter relate, in the first place, to parliament's (1) right to demand information and (2) power to influence the government's position in EU negotiations ${ }^{6}$ and (3) power to sanction the government for deviating from its prescribed position.

Instruments on the right to demand information of parliament are instruments that ensure that parliament receives information on EU affairs, such as EU legislative documents and which require the government to inform parliament on its negotiation goals and strategies (such as hearings or committees). This relates not only to the quality and the quantity of information given, but also to the (early) delivery thereof as well as the time span given that is given to parliament to scrutinize the information that it has received. It also includes parliament's capacity to deal with the amount of information, ${ }^{7}$ as in EU matters especially, national parliaments are often overburdened with documents. Falling into this category is also the creation of European Affairs Committees (EACs), as well as the participation of sectoral standing committees in EU affairs in order for parliament to be able to "monitor the EU-level decision-making process and to form and discuss views on the government's conduct." Such instruments are intended to reduce any information asymmetries that may exist between government and parliament.

4 A. Groen, T. Christiansen, "National Parliaments in the European Union: Conceptual Choices in the European Union's Constitutional Debate”, in: C. Hefftler, C. Neuhold, O. Rozenberg, J. Smith (eds.), The Palgrave Handbook of National Parliaments and the European Union, Palgrave Macmillan: United Kingdom, 2015, p. 5.

5 W. Müller, T. Bergman, K. Strom, “Parliamentary Democracy: Promise and Problems”, in K. Strom, W. Müller, T. Bergman (eds.), Delegation and Accountability in Parliamentary Democracies, Oxford University Press: New York, USA, 2006, pp. 3-32; K. Auel, "Democratic Accountability and National Parliaments: Redefining the Impact of Parliamentary Scrutiny in EU Affairs”, (2007) 13 European Law Journal, pp. $487-$ 504.

6 T. Winzen, "European Integration and National Parliamentary Oversight Institutions", (2013) 14 European Union Politics, p. 300.

$7 \quad$ Auel, supra note 5, p. 489.

8 Winzen, supra note 6, p. 300. 
The second category of rules comprise those which are intended to counter the lack of parliamentary involvement under the decision-making structures at the European level. ${ }^{9}$ An example of this type of oversight mechanism is the so-called 'scrutiny reserve', which does not allow for the government to make a decision at EU level until such times as the domestic scrutiny process has finished. This type of instrument also includes mandating procedures, which allows parliament to instruct the government with regard to its position in EU matters. Mandating procedures can be both non-binding and binding on the government, with different degrees of severity in relation to the sanctions that follow in the event of non-compliance therewith. Both the first and the second category of parliamentary instruments are ex ante mechanisms, i.e., they are applied before the government takes a decision at EU level.

The third instrument - the power to sanction the government for deviating from its prescribed position - can only be triggered ex post, after a decision has been taken at the EU level. While parliament no longer has the power to change the decision, its effects should nevertheless not be underestimated. Thus, often the mere possibility or the threat of a sanction may be effective in limiting any agency loss. Its impact lies less in its application and more in its existence. ${ }^{10}$

\subsubsection{Right to information vis-à-vis the national governments and European Affairs Committees}

Instruments that pertain to the right of parliament to demand information are instruments that ensure that parliaments receive information on EU affairs, such as EU legislative documents and those documents which require the government to inform parliament on its negotiation goals and strategies (such as hearings or committees). This relates not only to the quality and the quantity of information given, but also to the (early) delivery thereof as well as the time span that is given to parliament to scrutinize the information. It also includes the capacity of parliament to deal with the amount of information received, ${ }^{11}$ as in EU affairs especially national parliaments are often overburdened with information. Falling into this category is also the creation of European Affairs Committees, as well as the participation of sectoral standing committees in EU affairs in order for parliament to be able to "monitor the EU-level decision-making process and to form and discuss views on the government's conduct."12 Such instruments are thus intended to reduce the information asymmetries that exist between government and parliament. All Member States have established an EAC in their own domestic systems, which all perform similar functions,

$9 \quad$ Ibid.

10 S. Siefken, "Parlamentarische Frageverfahren - Symbolpolitik oder wirksames Kontrollinstrument?", (2010) Zeitschrift für Parlamentsfragen, p. 34.

11 Auel, supra note 5, p. 489.

12 Winzen, supra note 6, p. 300. 
even though their importance differs from country to country. The Danish EAC and the EAC of the Austrian Nationalrat and the EAC of the German Bundesrat are thus regarded as being very strong committees with binding powers vis-à-vis the government, whereas the EACs in Belgium, Greece, Italy, Portugal and Spain, for example, serve more as a forum for the exchange of information. ${ }^{13}$ They also differ with regards to their composition, as some EACs include Members of the European Parliament whereas others do not.

\subsubsection{Scrutiny reserves and mandating systems}

The second category of rules are those which are intended to "remedy the changes in the structure of decision-making that enable governments to take choices at the EU level without parliament having had the chance to even consider an issue." ${ }^{14}$ An example of this type of oversight mechanism is the 'scrutiny reserve', which prohibits the government from making a decision at EU level, until such times as the domestic scrutiny process has been carried out by the national parliament. The scrutiny reserve intends to ensure that parliament has some opportunity to scrutinize any EU action before it is adopted and to possibly influence their government's position in the negotiations. In a similar manner, but going a bit further, the mandating procedures requires the government to obtain a parliamentary mandate before negotiating in the Council. Mandating procedures can be both non-binding and binding on the government, with different degrees of severity of the sanctions that follow for non-compliance therewith. Both the scrutiny reserve and the mandating procedures are ex ante mechanisms, i.e., they are applied before the government takes a decision at EU level.

A type of scrutiny reserve has been specifically established in the United Kingdom, the Czech Republic, Malta, France, Germany, Italy and the Netherlands. ${ }^{15}$ In the United Kingdom, for example, the government may in general not agree to any legislative proposal which has not yet been debated by parliament or which has not been cleared by the European Scrutiny Committee. ${ }^{16}$ The system is documents-based in that parliament focuses on reviewing all EU documents and the government's position in relation thereto. ${ }^{17}$ Exceptions to the scrutiny reserve are also set out in the House of Common's scrutiny reserve resolution. Paragraph 3 of that aforementioned resolution states that ministers may agree to a proposal which is still subject to scrutiny by parliament if he or she considers the proposal

13 T. Bergman, "National Parliaments and EU Affairs Committees: Notes on Empirical Variation and Competing Explanations”, (1997) 4 Journal of Public Policy, p. 377.

14 Winzen, supra note 6, p. 300.

15 K. Auel, O. Rozenberg, A. Thomas, "Lost in Transaction? Parliamentary Reserves in EU Bargains", (2012) OPAL Online Paper Series 10/2012, p. 4.

16 House of Commons Resolution of 17 November 1998 on the Scrutiny Reserve.

17 House of Commons, The European Scrutiny System in the House of Commons - A Short Guide for Member of Parliament by the Staff of the European Scrutiny Committee, available at: <https://www.parliament.uk/documents/upload/theeuroscrutinysysteminthehoc.pdf> (last retrieved on 31 October 2017), p. 5. 
to be confidential, routine or trivial or substantially the same as a proposal which has already undergone the scrutiny procedure or which the European Scrutiny Committee already has approved, even though it has not yet been considered by the House of Commons. In any such case, however, the minister is obliged to immediately inform the European Scrutiny Committee or the House of Commons, and to explain his or her reasons for overriding the reserve, ${ }^{18}$ which are subsequently documented. For example, between January 2011 and December 2014, there were 250 overrides by the House of Lords, as was indicated in their report. ${ }^{19}$ The scrutiny reserve procedure in the Czech Chamber of Deputies is very similar to the UK system, as is the Maltese system, since both were modelled on the UK mechanism. ${ }^{20}$

The French réserve d'examen parlementaire, by way of contrast, is more limited because the government only has to wait eight weeks for a parliamentary opinion when it is a legislative proposal and only four weeks for all other proposed acts; ${ }^{21}$ unlike in the UK, where there is no time limit for the parliamentary reserve, the French parliament must complete its scrutiny within a given and specified period of time. ${ }^{22}$ Also in Germany, the scrutiny reserve (Parlamentsvorbehalt) is restricted to a time limit based on the EU legislative schedule, according to Section 8(1) of the Act on Cooperation between the Federal Government and the German Bundestag in Matters concerning the European Union (Gesetz über die Zusammenarbeit von Bundesregierung und Deutschem Bundestag in Angelegenheiten der Europäischen Union, EUZBBG) ${ }^{23}$ Under Article 23(3) of the German Basic Law and Section 8 of the EUZBBG, the German government must give parliament the opportunity to give its opinion before participating in an EU project. But because parliament is bound by the EU legislative schedule, the government is actually not obliged to make use of a scrutiny reserve in the case that scrutiny by the Bundestag has not been completed by the time that the Council makes a formal decision, ${ }^{24}$ even though it does have to be taken into consideration by the government in the Council negotiations once it is rendered (Sections $8(2)$ and (3) of the EUZBBG). The government may override the reserve for good reasons

18 Scrutiny Reserve Resolution, supra note 16, para. 4.

19 House of Lords, European Union Committee, Report on 2014-2015, published 3 July 2015, HL Paper 11, p. 12.

20 Auel, Rozenberg, Thomas, supra note 15, pp. 7-8.

21 Fiche de synthèse $n^{\circ} 56$ : L'assemblée nationale et les questions europénnes, available at: http://www2.assemblee-nationale.fr/decouvrir-1-assemblee/role-et-pouvoirs-de-1-assemblee-nationale/1assemblee-nationale-et-les-questions-europeennes/l-assemblee-nationale-et-les-questions-europeennes (last retrieved on 31 October 2017).

22 Auel, Rozenberg, Thomas, supra note 15, p. 9.

23 Act on Cooperation between the Federal Government and the German Bundestag in Matters concerning the European Union (EUZBBG) of 4 July 2013 (Federal Law Gazette I, p. 2170). English translation available at: <www.bundestag.de/blob/194644/3bb22495d486c0808721839b96dbc1a3/euzbbg_juli_2013_en-data.pdf> (last retrieved on 11 September 2014).

Ibid., pp. 9-10. 
of foreign or integration policies (Section 8(4) of the EUZBBG), however if this is the case then it must be justified. These examples show that even though a number of national parliaments have some kind of scrutiny procedure implemented in their domestic systems, these procedures can nevertheless differ with regards to their scope and timing constraints.

The strongest form of a scrutiny reserve is known as the mandating procedure. It is most famously employed by the Danish Folketing and includes parliament's right to mandate its minister with regards to EU negotiations. This means that a minister may not agree to a legislative proposal at EU level, unless parliament has given them the mandate to do so. Such a procedure, by its very nature, also entails a scrutiny reserve in the stricter sense. In the case of Denmark, it is the European Affairs Committee of the Folketing that typically issues such mandates, usually a week before a Council meeting and generally regarding what it considers to be the important issues. ${ }^{25}$ Other Member States that have implemented a mandating system that is similar to the Danish one are Austria, Estonia, Finland, Lithuania, Poland, Slovakia, Slovenia and Sweden. ${ }^{26}$

In general, there exists a considerable amount of variation between the different Member States and their national parliaments' powers to control the government and there is a vast amount of literature classifying EU Member State parliaments into different categories, some stronger and some weaker in their ability to oversee governmental action at EU level. ${ }^{27}$

The third instrument follows from the second power and is the power to sanction the government for deviating from its prescribed position, which is more important in an ex post manner, i.e., after a decision has been taken at EU level.

\subsection{The German Bundestag}

The parliament which will be considered in this chapter is the German Bundestag. It will be shown in this chapter that it has a rather strong role vis-à-vis the German government,

25 Ibid., p. 12.

26 Ibid.

27 See, for example: K. Auel, O. Rozenberg, A. Tacea, "Fighting Back? And, If So, How? Measuring Parliamentary Strength and Activity in EU Affairs”, in: C. Hefftler, C. Neuhold, O. Rozenberg, J. Smith (eds.), The Palgrave Handbook of National Parliaments and the European Union, Palgrave Macmillan: United Kingdom, 2015, pp. 60-93; T. Winzen, "National Parliamentary Control of European Union Affairs: A Cross-National and Longitudinal Comparison", (2012) 35 West European Politics, pp. 657-672; T. Raunio, "Holding Governments Accountable in European Affairs: Explaining Cross-National Variation”, in: K. Auel, A. Benz (eds.), The Europeanisation of Parliamentary Democracy, Routledge: United Kingdom, 2006, pp. 17-40; A. Maurer, W. Wessels, "National Parliaments after Amsterdam: From Slow Adapters to National Players?", in: A. Maurer, W. Wessels (eds.), National Parliaments on their Ways to Europe: Losers or Latecomers?, Nomos Verlagsgesellschaft: Baden-Baden, Germany, 2001, pp. 425-475. 
a position that has been recently strengthened by the actions of the German Federal Constitutional Court.

\subsubsection{The right to demand information}

\subsubsection{The right to summon the government}

The most basic right of the German parliament vis-à-vis the government is enshrined in Article 43(1) of the German Basic Law (Grundgesetz, GG). ${ }^{28}$ This constitutional provision, which provides for the parliamentary right to summon the government, lays the basis for the relationship between Bundestag and the Federal Government. ${ }^{29}$ Under Article 43(1) of the GG, the Bundestag and its parliamentary committees have the right to require the presence of any member of the Federal government at their sittings and meetings. This procedure allows the Bundestag to continuously stay in contact with the government, thus facilitating the exercise of its control functions. ${ }^{30}$ Conversely, the government has the right to attend all parliamentary sittings and committee meetings and the right to be heard at any time.

\subsubsection{The right to ask questions}

The German Federal Constitutional Court has repeatedly held that the parliamentary right to information and to ask questions follows from the principle of democracy that is contained under Articles 20(2) and 38(1) of the GG, especially if interpreted in light of the right of the Bundestag to summon the government as per Article 43(2) of the GG. ${ }^{31}$ Article 20(1) of the GG proclaims that the Federal Republic of Germany is a democratic and social federal state. The second sentence of Article 20(2) of the GG states that all state authority "shall be exercised by the people through elections and other votes and through specific legislative, executive and judicial bodies." The second sentence of Article 38(1) of the GG states that the members of the German Bundestag $(\mathrm{MdB})$ are the "representatives of the whole people, not bound by orders or instructions, and responsible only to their conscience."

Hence, the principle of democracy that is enshrined in the German Basic Law requires the Bundestag to be able to have access to the information, which it needs in order to prepare and evaluate its decisions. In its judgment of September 2012, the BVerfG even went as far as stating that the "core of the right of parliament to be informed is therefore also

28 English translation available at: <https://www.bundestag.de/blueprint/servlet/blob/284870/ ce0d03414872b427e57fccb703634dcd/basic_law-data.pdf> (last retrieved on 11 September 2014).

29 H.-J. Vonderbeck, Parlamentarische Informations- und Redebefugnisse, Duncker \& Humblot: Berlin, 1981.

30 Ibid.

31 BVerfG, 2 BvE 5/06 vom 1.7.2009, para. 123. 
entrenched in Article 79 (3) of the Basic Law." ${ }^{32}$ Article 79(3) of the GG provides that "amendments to this Basic Law affecting the division of the Federation into Länder, their participation on principle in the legislative process, or the principles laid down in Articles 1 and 20 shall be inadmissible." By putting the parliamentary right to information under the protection of the eternity clause, the BVerfG has demonstrated the vital importance thereof for a democratic state. Such protection does not only apply in national budgetary law but also in relation to EU matters (for the participation of the Bundestag in matters concerning the European Union, see Section 4.3.1.8). ${ }^{33}$

The details of the Bundestag's right to ask questions are regulated by $\$ \$ 100-106$ of the Rules of Procedures of the Bundestag (Geschäftsordnung, RoP), ${ }^{34}$ whereby different forms of parliamentary questions can be distinguished: ${ }^{35}$ major interpellations (Große Anfragen), minor interpellations (Kleine Anfragen), written questions (Schriftliche Fragen) and question times (Fragestunden). In addition, parliament may initiate debates on topical issues (Aktuelle Stunden) and put questions to the government (Befragung der Bundesregierung). The different forms of interpellation will be explained in more detail below.

They all, however, serve the same purpose, as was made clear by the Bundesverfassungsgericht in its ruling of 1 July 2009. ${ }^{36}$ All different forms of questions enable the Bundestag to fulfill its control functions, from which the right to ask questions is derived.$^{37}$ For that reason, such a right does not necessarily only include the right of parliament to ask questions but it also includes the government's obligation to reply. Both aspects constitute two sides of the same coin and are, together with Article 43(1) of the GG, fundamental for an effective exercise of its control function by the Bundestag. ${ }^{38}$ This entails a requirement that the government's reply be justified and substantiated. It must answer the entirety of the parliamentary questions that have been asked and may not hide behind vague clauses so as not to undermine the Bundestag's control function. ${ }^{39}$

It is important to note, that it is rather difficult to prove the effect of parliamentary interpellations on the governmental policy-making. Instead, the right of the Bundestag to ask questions plays an important role for parliament's public functions, because the interpellations enable a wide range of information on the actions of the government to be made publicly available. ${ }^{40}$ Plenary debates in the Bundestag are held in public, unless a

32 BVerfG, 2 BvR 1390/12 vom 12.9.2012, para. 215.

33 Ibid.

34 Rules of Procedure of the German Bundestag of 2 July 1980 (Federal Law Gazette I, p. 1237), as last amended 12 June 2017 (Federal Law Gazette I, p. 1877). An English translation of the old version of 2014 can be found here: <https://www.btg-bestellservice.de/pdf/80060000.pdf > (last retrieved on 14 February 2018). Siefken, supra note 10, p. 21; BVerfG, 2 BvE 5/06, supra note 31, para. 88.

36 BVerfG, 2 BvE 5/06, supra note 31.

37 Ibid., para. 88.

38 Ibid., para. 75.

39 Ibid., para. 76.

40 Siefken, supra note 10, p. 33. 
two-thirds majority objects upon the motion of one tenth of its members or of the Federal Government (Article 42 of the GG).

\subsubsection{Major interpellations (Große Anfragen)}

Major interpellations are dealt with in $\$ \$ 100-103$ of the RoP. They are addressed to the Federal Government in written form. At least five percent of the members of the Bundestag or a parliamentary group are needed in order to submit a major interpellation to the President of the Bundestag, who forwards the interpellation to the government and asks the latter to reply to it. After a reply has been received (or if the government refuses to reply within a time period of three weeks), the major interpellation is debated at the plenary session. Generally, major interpellations concern important political issues and such a public debate enables the opposition party to ask critical questions as well as to publicly highlight their opinion on the matter. ${ }^{41}$ More often than not they relate to the government's general direction of policy-making - as opposed to precise individual cases - and serve as an important scrutiny instrument thereof. ${ }^{42}$

Between October 2009 and August 2014, 57 major interpellations were submitted to the Bundesregierung, out of which six contained the European Union as a key word (for a complete overview over the number of the different types of questions asked with regard to different subject matters, see Section 4.3.1.7.). These six major interpellations concerned: the position of the Federal Government in relation to the future of the West Sahara and the human rights situation in Morocco, including decisions taken by the EU; the rule of law in Russia, including the modernization partnership with the EU; the situation of Roma in the EU and in the (potential) candidate countries; the climate diplomacy in Germany, including the commitment of some EU Member States to a European climate protection policy, partnerships with accession countries in Middle and Eastern Europe and coherent international representation of the EU; securing Germany's technological leadership in the traffic and building sector, including the cooperation with the EU and the sociological, ecological, economic and political effects of the EU-USA free trade agreement.

\subsubsection{Minor interpellations (Kleine Anfragen)}

Minor interpellations, on the other hand, deal with more narrow issues and aim to control and criticize the government's concrete performances. ${ }^{43}$ They are regulated by $\$ 104$ of the RoP. The questions, which are focused on a specific issue and may not contain any subjective statements or evaluations, are answered only in writing. They must be submitted to the President of the Bundestag, who then forwards them to the Federal Government, who

41 Bundestag website, Instruments of scrutiny, available at: <https://www.bundestag.de/en/parliament/function/scrutiny/instruments_scrutiny/245710> (last retrieved on 12 February 2018).

42 Siefken, supra note 10, p. 27.

43 Ibid. 
then has two weeks to reply. Between October 2009 and August 2014, a total of 4339 minor interpellations were submitted; 294 of which concerned the European Union. A few examples are the practice of rejecting irregular immigrants at the EU external border in Greece and Bulgaria without formal procedures; the cooperation and projects of European police forces in the first half of 2013; the implementation of the European Youth Guarantee in Germany; the policies of the EU and the Federal Government vis-à-vis Libya and Tunisia in the areas of Justice and the Interior; the preparation of the European Council meeting on 19/20 December on the future development of the Common Security and Defence Policy and the development of the European labour market since the outbreak of the 2007 financial crisis.

\subsubsection{Questions by individual MdB (Fragen einzelner Mitglieder des Bundestages)} In addition, every member of the Bundestag has the right to put questions to the government for oral or written reply ( $\$ 105$ of the RoP). The details are regulated in Annex 4 to the RoP.

\subsection{Written questions (Schriftliche Einzelfragen)}

Every member of the Bundestag has the right to submit four written questions to the government every month (Rule 13, Annex 4 of the RoP). They must be answered in writing by the government within one week of receipt by the Federal Chancellery (Rule 14, Annex 4 of the RoP) and when this has not happened, the questioner may request his question to be answered orally during the first question time (see below) in the week of sittings following the expiration of the time limit (Rule 15, Annex 4 of the RoP). Between October 2009 and August 2014, 22.785 written questions were asked by individual MdBs, out of which 525 contained the keyword European Union.

\subsection{Oral questions (Fragestunden)}

Oral questions may be asked in so-called 'question times' (Fragestunden), which are held each week of sittings. During a maximum time period of 180 minutes, any member of the Bundestag may ask up to two questions to the government, which in turn can be divided into two sub-questions (Rule 1, Annex 4 of the RoP). They are generally answered orally, except for questions relating to an item of the agenda of the current week of sittings, which are answered in writing (Rule 2, Annex 4 of the RoP). When a question is answered orally, the $\mathrm{MdB}$ asking the question is entitled to ask two supplementary questions (Rule 3, Annex 4 of the RoP). Oral questions must be submitted on the Friday preceding the week of sittings (Rule 8, Annex 4 of the RoP) and questions that are not answered during question times due to lack of time are to be answered by the government in writing, unless they have been withdrawn by the questioner (Rule 12, Annex 4 of the RoP). Between October 2009 and August 2014, the MdB posed 6737 oral questions in total, 283 of which concerned the EU. 


\subsubsection{Matters of topical interest (Thema von allgemeinem aktuellem Interesse)}

$\$ 106$ of the RoP provides the right of the Bundestag to hold a debate or put questions to the government on 'matters of topical interest' (Thema von allgemeinem aktuellen Interesse), the details of which are regulated in Annex 5 of the RoP.

\subsection{Debates on matters of topical interests (Aktuelle Stunde)}

$\$ 106(1)$ of the RoP provides the right of the Bundestag to conduct debates on clearly defined topics of general current interest. They may be held once on every day on which the Bundestag is sitting, if agreed upon in the Council of Elders or if requested by at least five percent of the members of the Bundestag or a parliamentary group (Rules 1 and 3, Annex 5 of the RoP). Each debate may not last for longer than one hour (Rule 6, Annex 5 of the $\mathrm{RoP}$ ) and is conducted in the form of speeches not exceeding five minutes (Rule 106(1) of the RoP and Rule 7, Annex 5 of the RoP). Between October 2009 and August 2014, a total of 146 debates were held; only one debate concerned the European Union, and more specifically it concerned the Fiscal Compact and its impact on democracy and the welfare state.

\subsection{Questions put to the government (Befragung der Bundesregierung)}

According to $\$ 106(2)$ of the RoP, the members of the Bundestag may put questions of topical interest to the government, which fall within the latter's competence and which primarily concern the preceding cabinet meeting, in weeks of sittings. Such questions must be put to the government on the Wednesday of the week of sittings (Rule 1, Annex 7 of the RoP) and should generally last around 30 minutes (Rule 4, Annex 7 of the RoP). In principle, it is the members of the government to whom the question was put that will answer the question (Rule 7, Annex 7 of the RoP). Between October 2009 and August 2014, 78 questions were put to the government but none concerned EU matters.

\subsubsection{Overview over number of questions asked by the Bundestag}

The following tables contain an overview of the number of questions asked by the German Bundestag during the $17^{\text {th }}$ legislative period and the first quarter of the $18^{\text {th }}$ legislative period. The overall numbers are the numbers that are regularly published by the statistics of the Bundestag on the number of interpellations and questions put to the government (Statistik der Parlamentarischen Kontrolltätigkeit). Matters relating to the EU are matters that do not directly concern the European Union, but nevertheless may touch thereupon. Matters relating to the European Union are those that are classified as such by the European Affairs Documentation Division of the Bundestag's administration (Referat PE5 EuropaDokumentation der Verwaltung des Deutschen Bundestags, see Section 4.3.1.20). They can, for example, be about the question of sanctions against Russia or the fight against international tax evasion. Matters concerning the European Union, on the other hand, are questions 
that are documented under the key word 'European Union' in the Parliamentary Material Information System (Dokumentations- und Informationssystem für Parlamentarische Vorgänge, DIP) of the Bundestag. Matters concerning the EMU are those listed under the key word 'Economic and Monetary Union' in the DIP.

\section{Table 1}

\begin{tabular}{|c|c|c|c|c|}
\hline & Overall $^{\mathrm{a}}$ & $\begin{array}{l}\text { Matters relat- } \\
\text { ing to the } \mathrm{EU}^{\mathrm{b}}\end{array}$ & $\begin{array}{l}\text { Matters con- } \\
\text { cerning the } \\
\text { EU }^{\mathrm{c}}\end{array}$ & $\begin{array}{l}\text { Matters con- } \\
\text { cerning the } \\
\text { EMUd }\end{array}$ \\
\hline $\begin{array}{l}\text { Major interpellations } \\
\text { (Große Anfragen) }\end{array}$ & 54 & 17 & 5 & 0 \\
\hline $\begin{array}{l}\text { Minor interpellations } \\
\text { (Kleine Anfragen) }\end{array}$ & 3629 & 681 & 228 & 19 \\
\hline $\begin{array}{l}\text { Oral questions by individual } \\
\text { MdB (Mündliche Fragen) }\end{array}$ & 6057 & 601 & 224 & 73 \\
\hline $\begin{array}{l}\text { Written questions by indi- } \\
\text { vidual MdB (Schriftliche } \\
\text { Fragen) }\end{array}$ & 20.141 & 1876 & 417 & 369 \\
\hline $\begin{array}{l}\text { Urgent questions (Dringliche } \\
\text { Fragen) }\end{array}$ & 107 & $\mathrm{n} / \mathrm{a}$ & 1 & 5 \\
\hline $\begin{array}{l}\text { Debates on matters of a } \\
\text { topical interest (Aktuelle } \\
\text { Stunde) }\end{array}$ & 131 & $\mathrm{n} / \mathrm{a}$ & 1 & 5 \\
\hline $\begin{array}{l}\text { Questions put to the govern- } \\
\text { ment (Befragung der Bun- } \\
\text { desregierung) }\end{array}$ & 69 & 4 & 0 & 2 \\
\hline $\begin{array}{l}\text { Motions for resolution } \\
\text { (Entschließungsantrag) }\end{array}$ & 383 & $\mathrm{n} / \mathrm{a}$ & 35 & 65 \\
\hline $\begin{array}{l}\text { Government statements } \\
\text { (Regierungserklärung) }\end{array}$ & 51 & $\mathrm{n} / \mathrm{a}$ & 19 & 23 \\
\hline \multicolumn{5}{|c|}{$\begin{array}{l}\text { a Statistik der Parlamentarischen Kontrolltätigkeit, Überblick 17. Wahlperiode (Stand der Datenbank 06.12.2013), } \\
\text { available at: <https://www.bundestag.de/blob/191010/9e9aeaca28d5660f9e360c3291468f4f/kon- } \\
\text { troll_taetigkeiten_wp17-data.pdf > (last retrieved on } 22 \text { August 2014). }\end{array}$} \\
\hline \multicolumn{5}{|c|}{$\begin{array}{l}\text { b Statistics provided by the Bundestag Referat Europa-Dokumentation on request of the author ( } 21 \text { August } \\
\text { 2014). }\end{array}$} \\
\hline \multicolumn{5}{|c|}{$\begin{array}{l}\text { ' Dokumentations- und Informationssystem für Parlamentarische Vorgänge des Deutschen Bundestages (DIP), } \\
\text { available at: <http://dipbt.bundestag.de/dip21.web/bt }>>\text { 'Beratungsabläufe' > 'einfache Suche' > with the fol- } \\
\text { lowing parameters: Wahlperiode '17' > Suchwort 'Europäische Union' > Vorgangstyp 'Große Anfragen', 'Kleine } \\
\text { Anfragen', 'Mündliche Fragen', 'Schriftliche Fragen', 'Dringliche Fragen', 'Aktuelle Stunden', 'Befragung der } \\
\text { Bundesregierung,' 'Entschließungsanträge', and 'Regierungserklärung' respectively (last retrieved on } 22 \text { August } \\
\text { 2014). }\end{array}$} \\
\hline \multicolumn{5}{|c|}{$\begin{array}{l}\text { d Dokumentations- und Informationssystem für Parlamentarische Vorgänge des Deutschen Bundestages (DIP), } \\
\text { available at: <http://dipbt.bundestag.de/dip21.web/bt }>>\text { 'Beratungsabläufe' > 'einfache Suche' > with the fol- } \\
\text { lowing parameters: Wahlperiode '17'> Suchwort 'Europäische Wirtschafts- und Währungsunion' > Vorgangstyp } \\
\text { 'Große Anfragen', 'Kleine Anfragen', 'Mündliche Fragen', 'Schriftliche Fragen', 'Dringliche Fragen', 'Aktuelle } \\
\text { Stunden', 'Befragung der Bundesregierung', 'Entschließungsanträge', and 'Regierungserklärung' respectively } \\
\text { (last retrieved on } 22 \text { August 2014). }\end{array}$} \\
\hline
\end{tabular}




\section{AN UNEVEN BALANCE?}

Table 1 shows the number of questions asked in the $17^{\text {th }}$ legislative period (between October 2009 and October 2013) and Table 2 exhibits those asked in the $18^{\text {th }}$ legislative period (from October 2013 until August 2014). Table 3 then presents the overall numbers of questions that were asked between October 2009 and August 2014.

\section{Table 2}

\begin{tabular}{|c|c|c|c|c|}
\hline & Overall $^{\mathbf{a}}$ & $\begin{array}{l}\text { Matters relat- } \\
\text { ing to the } \mathrm{EU}^{\mathrm{b}}\end{array}$ & $\begin{array}{l}\text { Matters con- } \\
\text { cerning the } \\
\text { EU }^{\mathrm{c}}\end{array}$ & $\begin{array}{l}\text { Matters con- } \\
\text { cerning the } \\
\text { EMU }^{\mathrm{d}}\end{array}$ \\
\hline $\begin{array}{l}\text { Major interpellations } \\
\text { (Große Anfragen) }\end{array}$ & 3 & 1 & 1 & 0 \\
\hline $\begin{array}{l}\text { Minor interpellations } \\
\text { (Kleine Anfragen) }\end{array}$ & 710 & 74 & 66 & 4 \\
\hline $\begin{array}{l}\text { Oral questions by individual } \\
\text { MdB (Mündliche Fragen) }\end{array}$ & 680 & 40 & 59 & 4 \\
\hline $\begin{array}{l}\text { Written questions by indi- } \\
\text { vidual MdB (Schriftliche } \\
\text { Fragen) }\end{array}$ & 2644 & 126 & 108 & 24 \\
\hline $\begin{array}{l}\text { Debates on matters of a } \\
\text { topical interest (Aktuelle } \\
\text { Stunde) }\end{array}$ & 15 & $\mathrm{n} / \mathrm{a}$ & 0 & 0 \\
\hline $\begin{array}{l}\text { Questions put to the govern- } \\
\text { ment (Befragung der Bun- } \\
\text { desregierung) }\end{array}$ & 9 & 1 & 0 & 0 \\
\hline $\begin{array}{l}\text { Motions for resolution } \\
\text { (Entschließungsantrag) }\end{array}$ & 59 & $\mathrm{n} / \mathrm{a}$ & 8 & 5 \\
\hline $\begin{array}{l}\text { Government statements } \\
\text { (Regierungserklärung) }\end{array}$ & 7 & $\mathrm{n} / \mathrm{a}$ & 4 & 4 \\
\hline \multicolumn{5}{|c|}{$\begin{array}{l}\text { a Statistik der Parlamentarischen Kontrolltätigkeit, Überblick 18. Wahlperiode (Stand der Datenbank 04.08.2014), } \\
\text { available at: <www.bundestag.de/blob/194874/acb8a6a36083f2198a874b0c67259b6e/kontroll_taetigkeiten_wp18- } \\
\text { data.pdf>, (last retrieved on } 22 \text { August 2014). }\end{array}$} \\
\hline \multicolumn{5}{|c|}{${ }^{\mathrm{b}}$ Statistics provided by the Bundestag Referat Europa-Dokumentation, supra note b Table 1.} \\
\hline \multicolumn{5}{|c|}{${ }^{\mathrm{c}}$ DIP search, supra note c Table 1, for Wahlperiode ' 18 '. } \\
\hline${ }^{\mathrm{d}}$ DIP search, supra note d Table & 1 , for Wahlp & & & \\
\hline
\end{tabular}


Table 3

\begin{tabular}{|c|c|c|c|c|}
\hline & Overall & $\begin{array}{l}\text { Matters relat- } \\
\text { ing to the EU } \\
\text { (Anfragen mit } \\
\text { EU-Bezug) }\end{array}$ & $\begin{array}{l}\text { Matters con- } \\
\text { cerning the } \\
\text { EU }\end{array}$ & $\begin{array}{l}\text { Matters con- } \\
\text { cerning the } \\
\text { EMU }\end{array}$ \\
\hline $\begin{array}{l}\text { Major interpellations } \\
\text { (Große Anfragen) }\end{array}$ & 57 & 18 & 6 & 0 \\
\hline $\begin{array}{l}\text { Minor interpellations } \\
\text { (Kleine Anfragen) }\end{array}$ & 4339 & 755 & 294 & 23 \\
\hline $\begin{array}{l}\text { Oral questions by individual } \\
\text { MdB (Mündliche Fragen) }\end{array}$ & 6737 & 641 & 283 & 77 \\
\hline $\begin{array}{l}\text { Written questions by indi- } \\
\text { vidual MdB (Schriftliche } \\
\text { Fragen) }\end{array}$ & 22.785 & 2002 & 525 & 393 \\
\hline $\begin{array}{l}\text { Debates on matters of a } \\
\text { topical interest (Aktuelle } \\
\text { Stunde) }\end{array}$ & 146 & $\mathrm{n} / \mathrm{a}$ & 1 & 5 \\
\hline $\begin{array}{l}\text { Questions put to the govern- } \\
\text { ment (Befragung der Bun- } \\
\text { desregierung) }\end{array}$ & 78 & 5 & 0 & 2 \\
\hline $\begin{array}{l}\text { Motions for resolution } \\
\text { (Entschließungsantrag) }\end{array}$ & 442 & $\mathrm{n} / \mathrm{a}$ & 43 & 70 \\
\hline $\begin{array}{l}\text { Government statements } \\
\text { (Regierungserklärung) }\end{array}$ & 58 & $\mathrm{n} / \mathrm{a}$ & 23 & 27 \\
\hline
\end{tabular}

The numbers show an impressive degree of activity by the Bundestag and its individual members with regard to their right to ask questions. Quantitatively, the use of this right can be evaluated positively in holistic terms. What is interesting to note, however, is the small fraction of questions that actually concern the EU or the EMU, i.e., that contain the terms 'European Union' or 'Economic and Monetary Union' as keywords. Thus, with regard to the written questions by MdBs, the percentage of questions that concern the EU only amounts to $2.3 \%$ of the total number; those concerning the EMU constitute only $1.7 \%$ of the total number. For major interpellations, the percentages are 10.5\% (EU) and 0\% (EMU) of all major interpellations submitted; the percentages of minor interpellations are $6.8 \%(\mathrm{EU})$ and $0.5 \%(\mathrm{EMU})$ respectively.

These numbers suggest that the focus seems to be on domestic matters as opposed to EU matters, insofar as it relates to their right to ask questions. The small fraction of questions that deal with the EU and the EMU might be explained by the fact that for matters concerning the European Union - and as a consequence, also matters concerning the EMU - the German Basic Law provides the Bundestag with a specific right to be constantly informed by the Federal Government, which serves the purpose of ensuring its participation 
in such matters. The participation of the Bundestag in matters concerning the European Union and the resulting right to information will be dealt with in the next section.

4.3.2 The participation of the Bundestag in matters concerning the European Union (Angelegenheiten der Europäischen Union)

The participation of the Bundestag in matters concerning the European Union (Angelegenheiten der Europäischen Union) is laid down in Articles 23(2) and (3) of the GG. In addition, Section 1 of the Act on the Exercise by the Bundestag and by the Bundesrat of their Responsibility for Integration in Matters concerning the European Union (Gesetz über die Wahrnehmung der Integrationsverantowrtung des Bundestages und des Bundesrates in Angelegenheiten der Europäischen Union, IntVG ${ }^{44}$ states that in such matters "the Bundestag and the Bundesrat shall exercise their responsibility for integration." According to Article 23(2) of the GG, the Bundestag has the right to be informed by the government on matters concerning the European Union, whereas Article 23(3) of the GG provides for its right to state its position before the government participates in EU legislative acts. ${ }^{45}$

Both rights are further specified in the Act on Cooperation between the Federal Government and the German Bundestag in Matters concerning the European Union. ${ }^{46}$ The following section will only deal with the parliamentary right to information. The right of the Bundestag to state its position will be considered in Section 4.3.2 concerning its power influence the government.

\subsubsection{Right to be informed on matters concerning the European Union}

In order to be able to exercise its control functions vis-à-vis the German government on EU matters, the Bundestag must be able to access comprehensive information on the activities of the government in relation thereto. As was mentioned above, the right of the Bundestag to information in EU matters is constitutionally enshrined in Article 23(2) of the GG, which provides that the Federal Government must inform the Bundestag (and the Bundesrat) "comprehensively and at the earliest possible time." This is also laid down in Section 13 of the IntVG and it is given further specification in Section 3(1) of the EUZBBG,

44 Act on the Exercise by the Bundestag and by the Bundesrat of their Responsibility for Integration in Matters concerning the European Union of 22 September 2009 (Federal Law Gazette I, p. 3022), as amended by Article 1 of the Act of 1 December 2009 (Federal Law Gazette I, p. 3822).

45 Articles 23(2) and (3) of the GG states that: "The Bundestag and, through the Bundesrat, the Länder shall participate in matters concerning the European Union. The Federal Government shall keep the Bundestag and the Bundesrat informed, comprehensively and at the earliest possible time. (3) Before participating in legislative acts of the European Union, the Federal Government shall provide the Bundestag with an opportunity to state its position. The Federal Government shall take the position of the Bundestag into account during the negotiations. Details shall be regulated by a law."

EUZBBG, supra note 23 . 
which adds that this must be done "continuously" in order to enable the Bundestag to "deliberate on [the notification's] content."

According to the Bundesverfassungsgericht, this means that the government's notification must allow the Bundestag to have an early and effective influence on the government's decision-making process. Only when it discloses a sufficient amount of information, is parliament in an adequate position to participate in the European decision-making process and to form a position thereon, as opposed to merely understanding the government's actions. ${ }^{47}$ The following sections will consider, in more detail, the different elements of the government's obligation to inform the Bundestag.

\subsubsection{Scope of 'matters concerning the European Union'}

The question of what falls within the meaning of the term 'matters concerning the European Union' also determines the scope of the information that the Bundestag is legally entitled to receive from the government. Section 1(2) of the EUZBBG states that matters concerning the European Union within the meaning of Article 23(2) of the GG include, in particular, and in accordance with Section 1(2) of the EUZBBG,

amendments to the Treaties and corresponding amendments at the level of primary law as well as legislative acts of the European Union. International agreements and intergovernmental arrangements are also matters concerning the European Union if they supplement, or are otherwise closely related to, the law of the European Union.

Such intergovernmental agreements were also the issue in a recent case before the Bundesverfassungsgericht. More specifically, the BVerfG found the Federal Government to have infringed the rights of the German Bundestag under Article 23(2) of the GG in relation to both the European Stability Mechanism (ESM) and the Euro Plus Pact. ${ }^{48}$ The German government had tried to argue that neither the ESM nor the Euro Plus Pact fell within the scope of 'matters concerning the European Union' - and thus under Articles 23(2) of the GG and the EUZBBG - as they constituted intergovernmental treaties that were concluded outside the EU law framework. ${ }^{49}$ Moreover, it tried to argue that decisions of the (still informal) Eurozone summit should not be treated in the same manner as decisions taken within the framework of EU law. ${ }^{50}$

The Bundesverfassungsgericht, however, disagreed. In its opinion, both the ESM and the Euro Plus Pact were to be considered an EU matter within the meaning of Article 23(2)

47 BVerfG, Judgment of 19 June 2012 - 2 BvE 4/11, para. 107.

48 Ibid., para. 133.

49 Ibid., paras. 58-60 and 66 respectively.

50 Höing, supra note 3, p. 16. 
of the GG, due to its close connection with the European Treaties and European law. Thus, the mere fact that the ESM was established by an international treaty outside the EU law framework did not affect its assignment to the integration programme laid down in both the TEU and TFEU, as it was closely intertwined with supranational elements, such as the involvement of the Union institutions or the Union's economic and monetary policy. ${ }^{51}$ According to the BVerfG, the term 'matters concerning the European Union' in Article 23(2) of the GG is to be interpreted widely and cannot be restricted to specific legal acts, as long as the matter in question relates to the European Union and its assigned integration programme. ${ }^{52}$ Thus, the participation of the Bundestag as an objective of Article 23(2) of the GG is not confined only to legislative acts, but it also includes other initiatives and legislative proposals that play a role in the Union's development and actions. For that reason, it must also be applicable to international treaties as long as the latter have substantial connections to the integration programmes of the TEU and TFEU respectively. ${ }^{53}$

\subsubsection{3 'Comprehensive'}

According to the Bundesverfassungsgericht, the requirement for the notification to be 'comprehensive' is to be understood that it must enable the Bundestag to exercise its participation rights. The more complex a matter is, the more it infringes upon the activities of the legislature and the closer the government gets to adopting a decision, then the more intensive the information provided should be ${ }^{54}$ This covers, in particular, the government's decision-making process, the preparation and course of discussions within the EU institutions, the opinions of the EP, the European Commission and the other Member States as well as any decisions that have been taken (Section 3(2) of the EUZBBG) ${ }^{55}$ It also includes the preparation and course of discussion at informal ministerial meetings, Euro summits, meetings of the Eurogroup and comparable intergovernmental institutions that are closely related to EU law (Section 3(3) of the EUZBBG). ${ }^{56}$ A non-exhaustive ${ }^{57}$ list can be found under Section 3 of the EUZBBG. In its judgment, the BVerfG commented on both the quality and the quantity of the documents to be transmitted to parliament.

\subsection{Quality of the information}

Qualitatively, the obligation to inform the Bundestag, first of all, includes documents and information on the initiatives and positions of the Federal Government itself. ${ }^{58}$ A detailed

\footnotetext{
51 BVerfG, 2 BvE 4/11, supra note 47, para. 100.

52 Ibid., para. 101.

53 Ibid., para. 103.

54 Ibid., para. 117.

55 The same applies to all preparatory bodies and working groups (Section 3(2) of the EUZBBG).

56 The same applies to all preparatory bodies and working groups (Section 3(3) of the EUZBBG).

57 BVerfG, 2 BvE 4/11, supra note 47, para. 100.

58 Ibid., para. 118.
} 
list on what documents should be provided can be found under Section 4(2) of the EUZBBG. ${ }^{59}$ This obligation, however, is not always fulfilled by the German government. Thus, concerning the documents and information on the initiatives and positions of the Federal Government itself, the Bundestag concluded in a report of August 2013 that during the $17^{\text {th }}$ legislative period, the government had not adequately fulfilled its obligation to inform parliament thereon.

Thus, according to the report, the Bundestag was only informed on a 'five-points-catalogue' on improving aviation safety that was presented by the Federal Minister of the Interior in the Justice and Home Affairs Council on 8 and 9 November 2010, one day after the Council meeting. Another example is the German-Franco initiative on postponing the accession of Bulgaria and Romania to the Schengen area that was addressed to the European Commission in a joint letter in December 2010, which was only transmitted to the Bundestag following a request from its own administration. The government also failed to inform the Bundestag in advance of the 'Pact for the Euro' (or the 'Euro-Plus-Pact') that was presented on $4^{\text {th }}$ February 2011 in the European Council in advance. For instance, the obligatory report submitted by the Federal Chancellery prior to the European Council meeting of $2^{\text {nd }}$ February 2011 does not contain any explanations thereupon. ${ }^{60}$

The German government tried to justify its omission to inform parliament by arguing that at the time of the presentation of both the 'five-points-plan' and the Euro-Plus-Pact, the government had yet to arrive at an internal formation of opinion. ${ }^{61}$ However, as the report also concluded, this is not a terribly convincing response. The first sentence of Section 4(2) of the EUZBBG states that "the Federal Government shall transmit to the Bundestag documents and information on the Federal Government's initiatives." Even if at the time in question no complete version of the initiative was available, the government could have nevertheless transmitted the information to the Bundestag on which its proposals were based. The failure of the government to inform the Bundestag on the Euro-Plus-Pact

59 Section 4(2) of the EUZBBG states: "The Federal Government shall transmit to the Bundestag:

1. documents and information on the Federal Government's initiatives, opinions, contributions to consultations, draft programmes and explanations for institutions of the European Union, for informal ministerial meetings, for euro summits and for the Eurogroup and comparable institutions that meet on the basis of international agreements and other arrangements which complement or are otherwise particularly closely related to the law of the European Union,

2. relevant initiatives, opinions, contributions to consultations and explanations from governments of Member States of the European Union,

3. relavant initiatives, opinions, contributions to consultations and explanations from the Bundesrat and the Länder, and coordinated instructions for the German representative on the Committee of Permanent Representatives.

The same shall also apply to all preparatory bodies and working groups."

60 Bundestag Drucksache 17/14601, "Unterrichtung durch den Präsidenten des Deutschen Bundestag: Erster Bericht über die Anwendung der Begleitsetze zum Vertrag von Lissabon", Report (2013), available at: <http://dipbt.bundestag.de/dip21/btd/17/146/1714601.pdf> (last retrieved on 11 September 2014), p. 22.

Ibid. 
was also dealt with by the Bundesverfassungsgericht in its ESM/Euro-Plus-Pact judgment. ${ }^{62}$ By omitting to transmit information on the Euro-Plus-Pact as well as unofficial documents by the President of the European Commission of $25^{\text {th }}$ February 2011 entitled "Enhanced Economic Policy Coordination in the Euro Area - Main Features and Concepts", the BVerfG held that the government infringed the Bundestag's right to be informed.

In the second instance, the obligation to provide information also concerns the transmission of EU documents and reports which have either been received by the government or which stem from the government itself, ${ }^{63}$ which are listed under Section 4(1) of the EUZBBG. ${ }^{64}$ The reports of the meetings must contain, at least, "the positions adopted by the Federal Government and other states, the course of negotiations, intermediate findings and final outcomes as well as any decisions for which parliamentary approval is required" (Section 4(1) of the EUZBBG). The obligation also includes the provision of information pertaining to unofficial documents that have been received by the government, which must be made available on request and as early as possible (Section 4(3) of the EUZBBG).

With regard to the documents and reports stemming from the government itself (or the Permanent Representation of the Federal Republic of Germany to the European Union) under Section 4(1), sentence 2, of the EUZBBG, the Bundestag received 1055 reports on Council meetings, 1315 reports on the sittings of COREPER, 4498 reports on the working groups of the Council and 506 reports on the sittings of the European Parliament and its committees between October 2009 and the end of January $2011 .{ }^{65}$ During the same period, 11.745 documents from the EU institutions were forwarded to the Bundestag. Because the responsible ministry only forwarded documents that were available in German, it was agreed with the Bundestagsverwaltung to transmit all relevant documents in the future in

62 BVerfG, 2 BvE 4/11, supra note 47.

63 Ibid., para. 118.

64 Section 4(1) of the EUZBBG states: "The notification of the Bundestag under section 3 of this Act shall be effected in particular through the transmission of all of the following items received by the Federal Government:

1. documents:

a. of the institutions of the European Union, the informal ministerial meetings, the Committee of Permanent Representatives and other Council committees and working groups,

b. of the euro summits, the Eurogroup and comparable institutions that meet on the basis of international agreements and other arrangements which complement or are otherwise particularly closely related to the law of the European Union,

c. of all bodies and working groups performing preparatory tasks for the institutions referred to in items $a$ and $b$ above,

2. reports from the Permanent Representation of the Federal Republic of Germany to the European Union or from the Federal Government concerning:

a. meetings of the institutions referred to in subparagraph 1 above,

b. sittings of the European Parliament and meetings of its committees,

c. the convening of trialogues and their proceedings and outcome, and

d. decisions of the European Commission."

Bundestag Drucksache 17/14601, supra note 60, p. 21. 
order to ensure the comprehensive and timely disclosure of information to the Bundestag. ${ }^{66}$ Overall, this constitutes an impressive number of documents, which gives no cause for concern with regard to the volume of information transmitted.

In addition, the Bundestag has the right to be informed, in writing and orally, about the subject matter of each European Council and Council meeting, informal ministerial meetings, Euro summit meetings and meetings of the Eurogroup, before these meetings take place. The notification must include the main features of the subject matter and the state of negotiations as well as the negotiating line of the Federal Government and its initiatives. After the meetings, the Bundestag is to be informed in writing and orally about the outcome thereof (Section 4(4) of the EUZBBG). According to its own report, the Bundestag considered this obligation to be adequately fulfilled during the $17^{\text {th }}$ legislative period. ${ }^{67}$ In general, every meeting of the Council and European Council was accompanied by a report thereon. Concretely, this resulted in 20 reports on the meetings of the European Council and 1055 reports on the meetings of the Council of Ministers, which were accompanied by oral explanations. The Bundestag was also content with the substantive requirements of the reports. ${ }^{68}$

At least every three months, early-warning reports on current political developments in matters concerning the European Union must be transmitted to the Bundestag (Section 4(5) of the EUZBBG). Under Section 4(6) of the EUZBBG, the Bundestag must also be notified of infringement proceedings under Articles 258 and 260 TFEU. ${ }^{69}$

\subsection{Quantity of the information}

According to the Bundesverfassungsgericht, the amount and detail of the information that must be given to the Bundestag depends both on the importance of the matter and the state of the negotiations. It is not the objective of Article 23(2) of the GG to flood the Bundestag with such an amount of information as to make it impossible for parliament to deal with, which is why it is possible for the government to submit the key points only where the matter is not important or where negotiations are at a very rudimental stage. In such a case, it is still possible for the Bundestag to demand more information. ${ }^{70}$ Moreover, the term 'comprehensive' implies that a singular instance of informing the Bundestag is not sufficient to fulfil this obligation. Instead, it entails the duty to do so continuously and

66 Ibid., p. 16.

67 Ibid., p. 25.

68 Ibid.

69 This includes letters of formal notice and reasoned opinions, as well as explanatory information and documents, particularly the response of the Federal Government where the proceedings are directed against Germany, and of proceedings before the CJEU to which Germany is a party or other proceedings, including pertinent documents relating thereto.

BVerfG, 2 BvE 4/11, supra note 47, paras. 120-121. 
every time that a new aspect or (legal) question arises, which has not yet been dealt with by parliament. ${ }^{71}$

\subsubsection{4 'At the earliest time possible'}

The condition stipulated in Article 23(2) of the GG that the information is given "at the earliest time possible" - in conjunction with the requirement that it must be comprehensive - is to ensure that the Bundestag is able to effectively exercise its participation rights. ${ }^{72}$ It is only when it is informed in due time that it is in a position to influence the decisionmaking process in the EU. For that reason, and in accordance with Section 4(1) of the EUZBBG, the Bundestag must be informed,

in advance and in sufficiently good time to form an opinion on the subject of the meetings and on the position of the Federal Government and to be able to influence the negotiating line and voting decisions of the Federal Government.

In practice, this means that the government may not take any decision without ascertaining the prior participation of the Bundestag (see Section 4.3.2.1 on the scrutiny reserve) and it is obliged to transmit any document as soon as it becomes the subject of the negotiations. ${ }^{73}$ Similarly, the government is obliged to transmit any official documents, reports and notes as well as unofficial information to the Bundestag as soon as they are received by the former. It must also inform the Bundestag about any sittings of the institutions or informal sessions before they take place in order for the latter to be able to form an opinion on the subject matter and to influence the government's voting behavior. The Bundestag is to be informed about the results immediately after the meetings. The government has no discretion as to the point in time at which it transmits the information. ${ }^{74}$

\subsubsection{Formal requirements}

The duty to notify the Bundestag is to be principally fulfilled in writing, through the disclosure of documents and reports by the government. Oral notifications are a supplementary addition and serve an explanatory function only (Section 3(1) of the EUZBBG). The addressee of the information is principally the entire Bundestag. Section 6(1) of the EUZBBG states the government must submit "all projects to the Bundestag with a forwarding letter" (for a list of what constitutes 'projects', see Section 4.3.1.10). This letter is based on the document that is to be forwarded and it contains the main substance and aim of the project,

\footnotetext{
71 Ibid., para. 122.

72 Ibid., para. 125.

73 Ibid., para. 127.

74 Ibid., para. 128.
} 
the date on which the German version of the relevant document appeared in the legal basis, the applicable procedure and the designation of the responsible ministry in question.

The responsibility for the transmission of the formal letters lies with the Federal Ministry for Economic Affairs and Energy (Bundesministerium für Wirtschaft und Energie, BMWi), which does so generally on the basis of Council documents. In doing so, it limits itself to German-language documents only, leaving all other documents for the other ministries to identify new projects in their respective subject areas. The BMWi does not, however, control whether or not the other ministries fulfill this obligation. ${ }^{75}$ It is difficult to determine whether this lack of coordination in the government adversely affects the transmission of the documents in question. Between October 2009 and the end of January 2011, 1407 of such documents were forwarded to the Bundestag. ${ }^{76}$

The language issue is rather problematic because many of the documents stemming from the EU institutions are not available in German, or are at least not yet available in German. Parliamentarians have complained about this and asked for the right to have access to complete German translations of all documents. ${ }^{77}$ However, waiting for them to be translated into the German language, and thereby postponing their transmission, is not an option either because this would impede the Bundestag's ability to participate in the matter. Nevertheless, the fact that no translation into the German language is available should not serve as a justification for the government to not forward the relevant documents. Instead, it could accompany the written English information with oral explanations in German.

\subsubsection{Limits to the right of information}

The duty of the government to inform the Bundestag is not an absolute one. Unaffected by the information right are the core areas of the government's executive responsibility (Section 3(4) of the EUZBBG). Such an executive responsibility results from the principle of the separation of powers and includes an "area of initiative, deliberation and action" that must be respected. ${ }^{78}$ Thus, the government is not required to inform parliament before it has internally decided its opinion in relation to the matter, unless the latter has evolved in such a specific direction that interim or partial results can be transmitted. ${ }^{79}$ It is also possible for the Bundestag to waive its right to receive notification in certain cases, provided

\footnotetext{
75 Bundestag Drucksache 17/14601, supra note 60, p. 11.

76 Ibid., p. 56.

77 European Parliament, Directorate-General for Internal Policies, Policy Department Citizens' Rights and Constitutional Affairs, "Democratic Control in the Member States of the European Council and the Eurozone Summits: In-depth Reports on 12 Member States”, Annex 2 (2013), p. 26; Bundestag Drucksache 17/14601, supra note 60, p. 12.

78 BVerfG, 2 BvE 4/11, supra note 47, para. 115.

Ibid.
} 
that no objection has been raised by a parliamentary group or five per cent of the Members of the Bundestag (Section 3(5) of the EUZBBG).

Another, more practical, limit has arisen within the context of the Eurozone crisis. The urgent nature of the crisis required fast (re-)actions by the Heads of State or Government in order to limit its repercussions for the economy. If it had to act under time pressures, the German government might have found itself unable (or perhaps unwilling?) to continuously inform the Bundestag about its actions and to wait for parliamentary approval. ${ }^{80}$ One example of this is the legislative proposal of the European Commission concerning the establishment of the EFSM of $9^{\text {th }}$ May 2010. The proposal was transmitted to the Bundestag on $11^{\text {th }}$ May 2010, which was the same day that the Council decided on its adoption and one day before its publication in the Official Journal of the EU, thereby leaving the German parliament with no room to 'participate' therein. In general, it seems that the Bundestag itself does not spend much time on legislative proposals concerning the euro crisis. Thus, while the average time between the motion for the proposal and the promulgation of a law is somewhere between 201 and 217 days, the period of time needed for the same process with regard to the crisis only averaged around 17 days. ${ }^{81}$ While it is understandable that the parliament does not and cannot occupy itself for months with legislative proposals whose adoption is urgently needed, it is nevertheless questionable whether it was able to adequately deal with the subject matter in such a short space of time, especially considering the usual complexity thereof.

\subsubsection{The Liaison Office (Verbindungsbüro)}

Section 11 of the EUZBBG provides for the establishment of a Bundestag Liaison Office (Verbindungsbüro) with the purpose of enabling the Bundestag to maintain direct contact with EU bodies insofar as this allows it to exercise its participatory rights in EU matters. The Liaison Office was established in 2007 and constitutes a direct link between the German parliament and the EU institutions. By being localized in Brussels, the Liaison Office is able to observe the preliminary decision-making processes in the EU institutions and build a strong informational network. It thus plays a vital role in ensuring that the Bundestag in Berlin is informed, in time, about EU projects.

Overall, the EUZBBG and the jurisprudence of the BVerfG provide for a very extensive and comprehensive - yet not exhaustive - list of matters concerning the European Union, on which the Bundestag has the right to be informed. The scope of the EUZBBG is not limited to legislative documents only, as following the BVerfG's case law, it also includes European Council meetings and informal euro summits, which was especially important

80 European Parliament; supra note 77, p. 26.

81 H. Scheller, "Fiscal Governance und Demokratie in Krisenzeiten", (2012) 13 Aus Politik und Zeitgeschichte, p. 14. 
during the crisis. The judgments of the BVerfG clearly aimed at strengthening the participation of the Bundestag in EU matters by vindicating its information rights. Nevertheless, the need to strike a balance between the government's core executive responsibilities and its obligation to inform parliament remains a delicate matter, which the BVerfG has decided not to comment on in any detail. Considering the amount of information available to the Bundestag, the question also poses itself as to what extent it is able to cope therewith.

\subsubsection{The ability of the Bundestag to process information}

The effective control of the Bundestag vis-à-vis the German government is not only dependent on the amount and the timing of the information received by it; it also depends on its ability to process such information. ${ }^{82}$ No amount of information can do any good if the parliament is not able to deal with it, and this is especially true for documents concerning EU matters given the volume and complexity thereof. Thus, parliaments often establish filter instances or specialized committees in order to process EU documents in good time. ${ }^{83}$ As the Bundestag does not dispose over a filter organ for incoming documents, the task of sifting through all the information received is incumbent on the parliamentary groups and the committees. ${ }^{84}$

For that reason, Article 45 of the GG provides for the appointment of a Committee on the Affairs of the European Union (EAC). The advantage of creating such a committee lies in its ability to efficiently deal with the information. It is possible that sectoral committees do not always possess the necessary expertise to deal with EU matters and that their working methods may not be suitable to monitor decision-making at the EU level because they lack speed and confidentiality. The drawback of an EAC is, however, that it tends to be more generalist without the technical expertise of the sectoral committees. ${ }^{85}$

However, it is not only the existence of a European Affairs Committee that determines the capability of parliament to deal with information. It also depends on the strength of such a committee, which relates to, for example, the frequency of committee meetings, whether it can meet during the parliamentary recess period or not and how many committees are involved in European affairs. ${ }^{86}$

82 Auel, supra note 5, p. 489.

83 European Parliament, Directorate-General for Internal Policies, Policy Department Citizens' Rights and Constitutional Affairs, "Democratic Control in the Member States of the European Council and the Eurozone Summits", Study (2013), p. 17.

84 A. Benz, J. Broschek, "Nationale Parlamente in der Europäischen Politik - Funktionen, Probleme und Lösungen", (2010) Friedrich-Ebert-Stiftung, Internationale Politikanalyse, p. 8.

85 P. Kiiver, The National Parliaments in the European Union - A Critical View on EU Constitution-Building, Kluwer Law International: The Hague, 2006, p. 49.

86

Auel, supra note 5, p. 489. 


\subsubsection{European Affairs Committee}

In the German Bundestag, the exercise of its control functions is done within its permanent committees. Each committee is specialized in a specific policy area and responsible for the preparation of the decisions of the Bundestag (Rule 54 of the RoP). The legal basis for the appointment of the European Affairs Committee is Article 45 of the GG. According to Rule $93 \mathrm{~b}(1)$ of the RoP, its task is to deal with EU documents as described under Rule 93 of the RoP. As a classical cross-policy committee (Querschnittsausschuss), it deals with principal questions on the EU as well as all other matters concerning the EU, insofar as they do not fall within the policy area of another committee. ${ }^{87}$ The current EAC in September 2014 consists of 34 MdBs and 14 German MEPs. ${ }^{88}$ The right of the latter to attend the meetings of the EAC is laid down in Rule $93 \mathrm{~b}(8)$ of the RoP. While they do not have any voting rights, they may participate in the work of the committee and thereby this ensures closer cooperation between the work in the Bundestag and in the EP.

\subsubsection{The powers of the EAC}

The EAC is, in the first instance, responsible for dealing with EU documents. Under the previous Rules of Procedures, the EAC was responsible for drawing up principles governing the treatment of EU items that are sent to it, which then served as the basis for the recommendations for resolutions submitted by the EAC to the Bundestag, or for the opinions that it addressed to the Federal Government (previously Rule 93b(9) of the RoP). This rule has been repealed in June 2017 with an amendment of the Rules of Procedure. It is the chairperson the EAC, who, in consultation with the other committees, makes a list of the EU documents that are to be referred to the committees for further discussion (Rule 93(5) of the RoP) and suggests which of those documents should be distributed on Bundestag headed paper (Rule 93(7) of the RoP). The responsible committees base their deliberations and recommendations for a resolution on the EU documents that are referred to them. Even when the Bundestag has stated its opinion on a particular document, it is the committee designated as the main committee that remains responsible for finding agreement with the government (Rules 93a(2) and (3) of the RoP). Where an EU document does not fall within any area of expertise of one of the sectoral committees, or where such an area cannot be discerned, the document falls within the responsibility of the EAC. It also discusses the meetings of the Council and the European Council during its sittings.

Moreover, according to the second sentence of Article 45 of the GG, the Bundestag may authorize the EAC to exercise its rights under Article 23 of the GG vis- $\grave{a}$-vis the Federal Government. It may also authorize the EAC to exercise the rights that have been granted

87 Benz, Broschek, supra note 84, p. 9.

88 Bundestag website, Ausschuss für die Angelegenheiten der Europäischen Union, available at: <https://www. bundestag.de/bundestag/ausschuesse18/a21/aufgaben_und_arbeit/aufgaben_und_arbeit/214768> (last retrieved on 11 September 2014). 
to it under the contractual foundations of the EU. Such an authorization is only allowed with regard to the EAC and is not endowed on any other committee, ${ }^{89}$ and can be done upon the motion of a parliamentary group or five percent of the members of parliament in relation to specifically designated EU documents. The EAC may also exercise those rights in the absence of an explicit authorization, so long as no committee concerned objects thereto (Rule $93 \mathrm{~b}(2)$ of the RoP). ${ }^{90}$ Such rights, however, are subject to certain conditions and do not in any way affect the right of the Bundestag to take a decision itself at any time on a matter concerning the European Union (Rule 93b(2) of the RoP). A limit to this rule may be a judgment that was handed down by the Bundesverfassungsgericht in 2012. Here, the FCC stated with regard to the budgetary committee that the Bundestag must fulfill its functions as a representative body in its entirety, i.e., through the participation of all of its members as opposed to (a group of) individual MdBs or the majority only. ${ }^{91}$ This is arguably also applicable mutatis mutandis to the EAC.

Rule 93b(3) of the RoP states that in case auf authorization pursuant to Rule 93b(2) of the RoP, the EAC must ask for an opinion on the EU document from the committees concerned, before intimating its opinion to the government. In case it wants to deviate from the opinion of one or more committees, a joint meeting with the relevant committees must be convened. This form of double consultation has been criticized for being too complicated and for impairing the transparency of the processes of the Bundestag, which in turn has an impact on its public function. ${ }^{92}$ Moreover, the EAC has to submit a report to the Bundestag on the content of and the reasons for its opinion that has been intimated to the government on EU documents. This report may be debated, if requested either by a parliamentary group or five percent of the members of the Bundestag (Rule 93b(6) of the RoP).

The EAC also has - by way of contrast to other committees - the right to submit a motion to the plenary to amend the recommendation for a resolution (Änderungsanträge zur Beschlussempfehlung) that was submitted by the responsible committee, when the EU document in question was referred to it for an opinion (Rule 93b(6) of the RoP).

\subsubsection{The frequency of EAC meetings}

As a general rule, committee meetings may take place on the authority of the chairperson of the committee concerned, as long as they fall within the scope of the timetable drawn up by the Council of Elders (Rule 60(1) of the RoP). As a means of derogating from that rule, however, the European Affairs Committee may also convene a meeting "outside the

89 See: BVerfG, 2 BvE 8/11 vom 28.2.2012, para. 66.

90 Exceptions are the Bereich der Gemeinsamen Außen- und Sicherheitspolitik sowie für Beschlüsse nach $\$ 9$ Absatz 1 des Integrationsverantwortungsgesetzes.

91 BVerfG, 2 BvE 8/11, supra note 89, paras. 101-102.

92 Benz, Broschek, supra note 84, p. 9. 
Bundestag's timetable or at a place other than the permanent seat of the Bundestag if the schedule of the relevant organs of the European Union so requires and the President has given consent" (Rule 93b(5) of the RoP). According to its own website, the EAC convened 93 times during the $17^{\text {th }}$ legislative period of the Bundestag (between October 2009 and October 2013). Out of the 93 meetings, 64 meetings were held in public and 19 were not. Ten meetings took place in form of a public hearing. The EAC dealt with 1558 items for discussion that were forwarded to it for an opinion and provided 24 recommendations for a resolution and reports to the plenary. ${ }^{93}$

The EAC of the Bundestag is an important part of its system, which is designed to control the Federal Government in EU affairs. It disposes over the necessary expertise to effectively monitor the government's activities at the EU level, which other committees lack. As a cross-policy committee, it is able to keep track of incoming EU documents and their distribution to the different sectoral committees. It lays the foundation for resolutions and opinions of the Bundestag in matters concerning the European Union, which it may even replace under certain conditions. Overall, the committee system of the Bundestag constitutes a crucial filter instance in dealing with the large volume of information that it receives, with the EAC being the main responsible committee in this regard.

\subsubsection{Internal staff and resources}

Another factor that contributes to parliament's ability to process information and to scrutinize EU affairs is its size when it comes to internal resources and staffing. Because parliaments, and consequently members of parliaments, have to deal with issues that are increasingly complex, they also have to increasingly rely on parliamentary services such as legal services, research divisions, parliamentary assistants and advisors to political groups in order to fulfill their functions. ${ }^{94}$ As members of parliament lack the time and resources to develop the technical knowledge and expertise that is required to take decisions in a fast-changing modern world, the work done by the support staff and civil servants in the administration thus plays a vital role for how effective parliament is in its work.

This does not mean that parliamentarians are not specialized - as they often do specialize through the committee structures in parliament - but for most of their legislative work they rely on the expertise and the work of the civil servants in parliament, who in contrast are experts and work full time in a particular field..$^{95}$ As a consequence not only the general

93 Bundestag website, available at: $<$ https://www.bundestag.de/bundestag/ausschuesse18/a21/bilanz_17_wahlperiode/260436> (last retrieved on 11 September 2014).

94 A.L. Högenauer, T. Christiansen, "Parliamentary Administrations in the Scrutiny of EU Decision-Making", in C. Hefftler, C. Neuhold, O. Rozenberg, J. Smith (eds.), The Palgrave Handbook of National Parliaments and the European Union, Palgrave Macmillan: United Kingdom, 2015, p. 116. For further analysis of the role of parliamentary administration in EU affairs, see also: A.L. Högenauer, C. Neuhold, "National Parliaments after Lisbon: Administrations on the Rise?”, (2015) 38 West European Politics, pp. 335-354.

Ibid., p. 118. 
legislative work but also the effective scrutiny of the government in EU affairs by national parliaments is dependent on the work, and thus on the size and expertise, of the support staff, on which they can rely when dealing with such matters. With regard to the latter, Christiansen et al. suggest in their research that a trend can be identified in national parliaments, in which a higher degree of Europeanization of parliament - i.e. a higher degree of changes to its internal procedures to adapt to developments on the European level also entails a higher degree bureaucratization of the latter, i.e. an increased use of the administration in parliamentary work. ${ }^{96}$

A difference is to be made between the parliamentary assistants that work for the individual MPs in the Bundestag and the civil servants that work for the administration (Bundestagsverwaltung). According to Paragraph 12(3) of the Act Regulating the Status of the Members of the German Bundestag (Gesetz über die Rechtsverhältnisse der Mitglieder des Deutschen Bundestages, AbgG) each MdB receives an allowance to hire staff members that assist them in their daily work. As of February 2017 such allowance amounts to $€ 20.870$ per MdB. ${ }^{97}$ The AbgG explicitly states that parliamentary assistants working for a member of the German Bundestag are not civil servants and have no employment relationships with the Bundestagsverwaltung. ${ }^{98}$ In contrast to the civil servants working in a parliament, parliamentary assistants - while nevertheless carrying out a wide range of tasks - are mostly focused on partisan work and the specific duties of their MP, e.g. constituency work.

Civil servants working in the German Bundestagsverwaltung, on the other hand, are obligated under Paragraph 60 of the Federal Civil Service Act (Bundesbeamtengesetz, BBG) to conduct their tasks independently and in a bipartisan manner. ${ }^{99}$ The Bundestagsverwaltung encompasses several departments with around 3000 civil servants overall. ${ }^{100}$ This means, depending on the exact number of the Bundestag, which changes with every general election, around four to four and a half civil servants per member of parliament. The

96 T. Christiansen, A.L. Högenauer, C. Neuhold, "National Parliaments in the post-Lisbon European Union: Bureaucratization rather than Democratization?”, (2014) 12 Comparative European Politics, pp. 121-140.

97 Bundestag website, Mitarbeiter, available at: <https://www.bundestag.de/abgeordnete/mdb_diaeten/1334d/260806> (last retrieved on 13 February 2018).

98 Paragraph 12(3) AbgG states: "Ein Mitglied des Bundestages erhält Aufwendungen für die Beschäftigung von Mitarbeitern zur Unterstützung bei der Erledigung seiner parlamentarischen Arbeit gegen Nachweis ersetzt. [...] Die Mitarbeiter sind nicht Angehörige des öffentlichen Dienstes. Es bestehen keine arbeitsrechtlichen Beziehungen zwischen den Mitarbeitern und der Verwaltung des Bundestages."

99 Paragraph 60 of the Federal Civil Service Act (BBG) of 5 February 2009 (Federal Law Gazette I, p. 160) states that: “(1) Beamtinnen und Beamte dienen dem ganzen Volk, nicht einer Partei. Sie haben ihre Aufgaben unparteiisch und gerecht zu erfüllen und bei ihrer Amtsführung auf das Wohl der Allgemeinheit Bedacht zu nehmen. Beamtinnen und Beamte müssen sich durch ihr gesamtes Verhalten zu der freiheitlichen demokratischen Grundordnung im Sinne des Grundgesetzes bekennen und für deren Erhaltung eintreten. (2) Beamtinnen und Beamte haben bei politischer Betätigung diejenige Mäßigung und Zurückhaltung zu wahren, die sich aus ihrer Stellung gegenüber der Allgemeinheit und aus der Rücksicht auf die Pflichten ihres Amtes ergeben."

100 Bundestag website, Die Verwaltung des Deutschen Bundestages, available at: <https://www.bundestag.de/parlament/verwaltung > (last retrieved on 11 February 2018). 
Bundestagsverwaltung is divided into four main departments, namely Directorate-General P on Parliament and Members, Directorate-General on Research and External Relations, Directorate-General on Information and Documentation and Directorate-General Z on Central Services, which in turn have several Directorates with a number of sub-divisions falling under them. ${ }^{101}$ Directorate PE on European Affairs falls under the DirectorateGeneral P and since 2013 in turn is comprised of six sub-divisions. Next to the secretariat of the EAC, the EU Liaison Office, the research section on EU affairs and the European affairs documentation division, there are also two divisions that focus on the analysis and prioritization of EU affairs and on fundamental EU matters and EMU matters respectively. ${ }^{102}$ Thus, the Directorate on EU affairs has its own department that deals with EMU matters such as the European Stability Mechanism, European Financial Stability Facility and Treaty on Treaty on Stability, Coordination and Governance in the Economic and Monetary Union. ${ }^{103}$ In the beginning of $18^{\text {th }}$ legislative period of the Bundestag in 2013 the PE Directorate on EU affairs had 64 staff members at its disposal. ${ }^{104}$ This means that for the 630 members of the Bundestag between 2013 and 2017 the ratio was approximately one EU expert staff member per ten MdBs.

\subsubsection{The power to influence the government}

Another important element of any parliament's power to control its government is the degree to which it is able to influence the government's position in EU negotiations. Influence in this context refers to the ability of parliament to change the government's position in EU negotiations in a way that would not have happened but for parliament's intervention. ${ }^{105}$ This can be done through the issuance of legally binding mandates or instructions. It can also be more subtle in nature, such as for example, by holding plenary debates before and after European Council meetings in order to make the parliament's view on the subject known and to possibly criticize the activities of the government ex post.

However, the way that parliamentary systems are designed results in what Auel refers to as a "dilemma of parliamentary influence." ${ }^{106}$ In a system, in which the government is

101 Bundestag website, Table of Organisation, available at: <www.bundestag.de/blob/189738/5f4ad574dc 0367e0b94830715585bcf0/orgplan-en-data.pdf> (last retrieved on 13 February 2018).

102 Ibid.

103 O. Höing, "With a Little Help of the Constitutional Court: The Bundestag on Its Way to an Active Policy Shaper", in C. Hefftler, C. Neuhold, O. Rozenberg, J. Smith (eds.), The Palgrave Handbook of National Parliaments and the European Union, Palgrave Macmillan: United Kingdom, 2015, p. 199.

104 Bundestag website, Der Bundestag stärkt seine Europa-Expertise, available at: $<$ https://www.bundestag.de/dokumente/textarchiv/2013/47765815_kw47_ua_europa/214002> (last retrieved on 13 February 2018).

105 Auel, supra note 5, p. 491.

106 Ibid. 
supported by the majority of parliament, it is very unlikely - at least with regard to domestic issues - that the said majority will oppose governmental proposals, as "support for a government of one's own becomes the most important task of the governing parliamentary majority." 107 And even while such sentiments might be less existent with regard to EU politics, due to the nature of EU decision-making and the number of actors therein, it is still unlikely that parliaments would want to publicly exercise their control over the government by issuing a mandate because it would almost be akin to opposing to its own government. ${ }^{108}$ Hence, while parliaments may dispose over the power to bind their government to a certain position, this does not mean that they will necessarily use that power. But even where they do not use that power, it cannot be concluded that they had no influence at all. Influence on EU affairs can, unbeknownst to the public, for example be ensured through informal cooperation within the coalition parties and with the government. It is also possible to conceive that the discussions held in plenary have an effect on the government's action at EU level, which is something which is neither obvious nor measurable. This is why this power remains rather difficult to assess.

\subsubsection{Scrutiny reserve and mandating procedures}

The scrutiny reserve finds its origin in a resolution that was promulgated by the UK parliament in 1980, which stated that ministers may not agree to matters in the Council until such times as the domestic parliamentary scrutiny process has ended. The rationale behind this is the same as the mandating procedures: in order to be able to influence the government's position in EU decision-making, the parliament must become active ex ante. ${ }^{109}$ Both instruments are closely related; scrutiny reserves can often be found implicitly in the mandating system of parliament because the latter implies that the government or its representative may not agree to a decision at EU level until they have received a mandate from their domestic parliament to do so. ${ }^{110}$ The term 'scrutiny reserve' (or 'parliamentary reserve') serves two purposes. First, it is the national rule that gives parliament sufficient time to complete the scrutiny process and second, it is the instrument through which national governments avail themselves at the European level, if they are not able to agree to a proposal. ${ }^{111}$

In Germany, the scrutiny reserve (Parlamentsvorbehalt) is laid down in the same provision that also regulates the right of the German Bundestag to issue binding instructions in EU matters, as they are closely intertwined with each other. Both Article 23(3) of the

107 Ibid., citing W. Patzelt, "What can an Individual MP do in German Parliamentary Politics?", in L. Longley, R. Hazan (eds.), The Uneasy Relationship between Parliamentary Members and Leaders, Frank Cass Publishers: New York, USA, 2000, pp. 23-24.

108 Ibid., p. 492.

109 Kiiver, supra note 85, p. 56.

110 See: Auel, Rozenberg, Thomas, supra note 15.

111 Ibid., p. 4. 
GG and Section 8 of the EUZBBG require the German government to give parliament the opportunity to deliver its opinion (Stellungnahme) prior to its participation in an EU project. The government must continuously transmit updated information on the course of its discussions to the Bundestag and thereby enable the latter to determine the time by which it seems appropriate to deliver an opinion based thereon. It also sets a specific date by which such an opinion should be delivered based on the EU legislative schedule (Section $8(1)$ of the EUZBBG). ${ }^{112}$

Here, the term 'project' includes not only legislative acts but also draft international agreements and other arrangements, if they are closely related to EU law, as well as items for discussion, proposals and initiatives being addressed in their framework (Section 5(1) of the EUZBBG) ${ }^{113}$ Thus, in this regard, the provision is quite broad in the sense that it encompasses de facto all decisions taken at EU level. Section 5(1) of the EUZBBG provides a non-exhaustive list in this regard. What is decisive is the character of the document and its qualification as an EU matter. On the other hand, it is restrictive insofar as the scrutiny must fit the EU legislative schedule. The government is not obliged to make use of a scrutiny reserve, if the scrutiny by the Bundestag has not been completed by the time that the Council makes a formal decision. ${ }^{114}$

Under Sections 8(2) and (3) of the EUZBBG, the parliamentary statements of opinion must be taken into consideration by the government in its negotiations. The government must continuously notify the Bundestag of the course of the negotiations, which also has the right to adapt and supplement its opinion during that time. These amendments and supplements must be considered by the government in the same manner as the original opinion. If it is not able to achieve one of the Bundestag's main demands, then the government is required to make use of the parliamentary reserve and to try and reach agreement with the Bundestag. Such an obligation does not, however, hinder the government from deviating from the Bundestag's opinion, if there are good foreign or integration policy reasons for doing so (Section 8(4) of the EUZBBG). After the final decision, the government must inform the Bundestag in writing and without delay, in particular, about the adoption of the parliamentary opinion. Deviations therefrom must be justified and where one quarter of the Members of the Bundestag so requests, the Federal Government must explain these reasons in the framework of a plenary debate (Section 8(5) of the EUZBBG). However, no rule exists with regard to what happens if the government cannot find an agreement with the Bundestag.

Thus, the German Bundestag has the right to issue instructions to the government, which are binding to the effect that the latter must provide a justification where it wishes

112 "Die Bundesregierung teilt mit, bis zu welchem Zeitpunkt auf Grund des Beratungsverlaufs eine Stellungnahme angemessen erscheint."

113 For a detailed list, see: Section 5 of the EUZBBG.

114 Auel, Rozenberg, Thomas, supra note 15, pp. 9-10. 
to deviate from those instructions. ${ }^{115}$ The parliamentary reserve comes into play in the case that it has not yet done so or where the government is unable to achieve its main demands during the negotiations. In these situations, the latter is required to put down the parliamentary reserve. This procedure allows the Bundestag to scrutinize the negotiations at the EU level where the government is unable or unwilling to follow its opinion and it forces the government to justify its position before possibly ignoring the opinion of the Bundestag. ${ }^{116}$

Between the period of October 2009 and January 2011, the Bundestag issued seven statements of opinion on legislative acts as provided for under Article 23(3) of the GG and 32 statements of opinions on EU matters as per Article 23(2) of the GG. A total of 134 proposed statements were not adopted by the plenary. ${ }^{117}$ Out of those seven issued statements of opinion under Article 23(3) of the GG, two fell within the scope of Section 9 of the EUZBBG on the opening of negotiation on accessions and treaty amendments. The first one concerned the Icelandic application for membership; the Bundestag was given the right to state its opinion, which was that it was in favour of Iceland joining the EU, before accession negotiations began. The second one concerned the accession of Serbia to the EU, which at the time of the report had not become the subject of negotiations, thus leaving ample time for the government and the Bundestag to reach agreement under Section 9 of the EUZBBG. Out of the remaining five statements of opinion, one agreed with the government's position and with regard to the other four, no parliamentary reserve was necessary during the period concerned. ${ }^{118}$ Consequently, it is rather difficult to evaluate the effectiveness of this provision.

There is no evidence to suggest that the German government did not fulfill its obligation to take the parliamentary statements of opinions into consideration, ${ }^{119}$ even though this does not necessarily have anything to say about its willingness to do so; it could also simply be possible that the opinion of the Bundestag coincided with the position of the Bundesregierung. The German government did, however, fail to inform the Bundestag in writing and without delay about the adoption of the parliamentary opinion. It was merely

115 The power of the Bundestag to instruct the government is weaker than that of the Bundesrat. Article 23(5) of the GG states that to the extent that the legislative powers of the Länder, the structures of Land authorities, or Land administrative procedures are primarily affected, the position of the Bundesrat shall be given "the greatest possible respect' in determining the Federation's position. This is usually understood as meaning that the government may not ignore the position of the Bundesrat but must align its own position in accordance thereto. See also: T. Range, "Europäische Verfassung: Neue EU-Kompetenzen für den Deutschen Bundestag”, (2004) Konrad-Adenauer-Stiftung Working Paper No. 136/2004, p. 7.

116 Auel, Rozenberg, Thomas, supra note 15, pp. 9-10.

117 Bundestag Drucksache 17/14601, supra note 60, p. 26.

118 Ibid.

119 Ibid., p. 27. 
informed in writing and orally about the outcome of the Council and European Council meetings under Section 4(4) of the EUZBBG. ${ }^{120}$

\subsubsection{2 (Practical) Limits to the mandating rights of the Bundestag}

While the Bundestag may bind the government to its position, there are certain (practical) limits to this right. First of all, the open nature of the agenda of European Council meetings, as well as the limited amount of draft texts that are circulated in advance, make it difficult for parliament to form an opinion thereon. ${ }^{121}$ This is, in the first place, an information problem. The second issue is that binding mandates may hinder the process of negotiations in the European Council (and the Council). ${ }^{122}$ If the government is bound by instructions that are too strict, it might not be able to enter into a compromise with the other Heads of State or Government. In the Council, where no unanimity requirement exists, an inflexible position of the government may even lead to an overall outcome whereby the parliamentary position is not considered at all. Thus, it might also be in the interest of the national parliament to formulate their instructions in an open manner and to only indicate a certain policy direction in order to allow the government to be able to negotiate in an adequate manner.

Even though the Bundestag has the right to issue binding instructions to the government which in turn trigger the scrutiny reserve, the effectiveness of this mechanism is difficult to determine, all the more so because parliament may also have an interest in leaving its instructions as open as possible so as to not to impose a strict mandate that could potentially backfire on them. In addition, no sanctions are available to the Bundestag in case the government decides not to follow its instructions. These two factors, it can be argued, may render the Bundestag's right to mandate the Bundesregierung useless. However, it cannot be excluded, nor should it be underestimated, that such instructions carry a certain amount of political weight, which might be difficult for the government to ignore.

\subsubsection{Obligation of the government to obtain prior parliamentary consent in matters concerning the ESM and EFSF}

Section 4(2) of the Act on Financial Participation in the European Stability Mechanism (Gesetz zur finanziellen Beteiligung am Europäischen Stabilitätsmechanismus, ESMFinG) ${ }^{123}$ requires the Federal Government to obtain an affirmative decision from the plenary before approving or abstaining from voting on a proposal for a decision in ESM matters. Where

120 Ibid., p. 28.

121 European Parliament, supra note 83, p. 48.

122 Benz, Broschek, supra note 84, p. 5.

123 Act on Financial Participation in the European Stability Mechanism of 13 September 2012 (Federal Law Gazette I, p. 1918). English translation available at: <www.bundestag.de/blob/192558/e6f4c478790ef5dfaf9 bff6fee02a31d/esmfing_en_2012-data.pdf> (last retrieved on 11 September 2014). 
such a plenary decision does not take place, the government is obliged to reject the proposal. ${ }^{124}$ The same obligation exists with regard to the European Financial Stability Facility (EFSF) under Section 3(1) of the Act on the Assumption of Guarantees within the Framework of a European Stabilisation Mechanism (Gesetz zur Übernahme von Gewährleistungen im Rahmen eines europäischen Stabilisierungsmechanismus, StabMechG). ${ }^{125}$ These provisions are commensurate with a series of judgments that have been handed down by the BVerfG concerning the Bundestag's budgetary rights (see Section 4.3.4).

\subsubsection{Plenary debates}

Another means of exerting influence over the Federal Government in European Council meetings is to hold plenary debates around such meetings. Even when the plenary does not adopt a binding state of opinion (see above), a plenary debate on the subject matter in question may nevertheless influence the government's approach to the negotiations or, at the very least, highlight the opinion of the parliamentary minority with regard to the topic. Thus, for example, the opposition parties traditionally use the yearly plenary debates on the budget as an opportunity to criticize the actions of the government. Throughout the crisis, an increase in debates could be observed with regard to the European Council and Eurozone summit decisions that became the subject of plenary debates in the Bundestag. ${ }^{126}$

Basing their findings on OPAL data, Auel and Raunio indicated in their study that between 2010 and 2012, the Bundestag held an average 42 debates on EU matters per year, which constituted almost 12 percent of the overall plenary time. ${ }^{127}$ This is, compared to the number of plenary debates on EU matters in Finland, France and the UK, the highest share. ${ }^{128}$ According to a 2012 report of the European Parliament, out of the 17 European Council meetings and eight Eurozone summits that were held between the entry into force of the Treaty of Lisbon in 2009 and June 2012, twelve summits were the subject of plenary debates in the Bundestag. They all lasted around two hours and began with an opening statement by the Chancellor. Almost all of them dealt with ordinary European Council meetings as opposed to informal and extra-ordinary ones, with a focus on the financial

124 In all other matter concerning the ESM, and which affects the budgetary responsibility of the Bundestag where a plenary decision is not required, the Budget Committee of the Bundestag must be involved (Section 5(1) of the ESM Financing Act).

125 Act on the Assumption of Guarantees within the Framework of a European Stabilisation Mechanism of 22 May 2010 (Federal Law Gazette I, p. 627). English translation available at: <www.bundesfinanzministerium.de/Content/EN/Standardartikel/Ministry/Laws/2010-05-22-stabilisation-mechanismact.pdf?_blob=publicationFile\&v $=2>$ (last retrieved on 11 September 2014).

126 European Parliament, supra note 77, p. 25.

127 K. Auel, T. Raunio, "Debating the State of the Union: Comparing Parliamentary Debates on EU Issues in Finland, France, Germany and the United Kingdom”, (2014) 20 The Journal of Legislative Studies, p. 20.

128 Ibid., p. 21. 
and economic crisis. ${ }^{129}$ The table below ${ }^{130}$ provides an overview of the plenary debates that took place in the Bundestag around the respective European Council meetings. It is important to note, however, that discussions on the outcomes of the summit are generally held at committee level; thus ex post control of the summits is exerted through the permanent committees. ${ }^{131}$ This was different up until the $15^{\text {th }}$ legislative period, until which such debates were held ex post; since then they have been held ex ante. ${ }^{132}$

The attitude of the Bundestag towards the European Union during these debates was generally positive; no change could be observed between 2009 and 2012. ${ }^{133}$ The proEuropean stance was often explained by the conception of the EU as a community of shared values, which serves the purpose of preserving peace after the events of the World War II, as well as by its conception as a global actor protecting the Member States from global competition. And while the opinion of the main parties seems to be coherent on the view that granting financial assistance to some Member States of the Euro are justified by the latter - the opposition parties also supported several major crisis government response measures - an issue concerning Germany's role vis-à-vis such other Member States could still be discerned. Hefftler and Höing found in their report that the arguments

evolve around a dichotomy of control of these MS and their own responsibility to overcome their economic problems on the one hand, and the need for cooperation and solidarity in Europe on the other hand (...)

with the first aspect arising much more often. ${ }^{134}$ Nevertheless, the German parliament's traditional pro-European attitude does not seem to have been affected by the crisis. ${ }^{135}$

129 European Parliament, supra note 77, pp. 26-27. This is line with the findings of Auel and Raunio. See: Auel, Raunio, supra note 127, p. 22.

130 Ibid., p. 28.

131 European Parliament, supra note 77, p. 40.

132 Auel, Raunio, supra note 127, p. 20.

133 See: European Parliament, supra note 77, pp. 29-30.

134 Ibid., p. 30.

135 Ibid., p. 31. 


\begin{tabular}{lll}
$\begin{array}{l}\text { Date of plenary } \\
\text { debate }\end{array}$ & European Council meeting & Main issue of debate \\
\hline 17 December 2009 & $\begin{array}{l}\text { 10/11 December 2009: ordinary Euro- } \\
\text { pean Council meeting }\end{array}$ & $\begin{array}{l}\text { Treaty of Lisbon (and UN climate } \\
\text { summit in Copenhagen) }\end{array}$ \\
\hline 25 March 2010 & $\begin{array}{l}\text { 25/26 March 2010: ordinary European } \\
\text { Council meeting }\end{array}$ & $\begin{array}{l}\text { EU 2020 Strategy } \\
\text { Preparation of financial aids packages }\end{array}$ \\
\hline 5 May 2010 & 7 May 2010: Eurozone summit & $\begin{array}{l}\text { First reading on federal law to allow } \\
\text { for financial aid for Greece }\end{array}$ \\
\hline 27 October 2010 & $\begin{array}{l}\text { 28/29 October 2010: ordinary Euro- } \\
\text { pean Council meeting }\end{array}$ & $\begin{array}{l}\text { Reform of the Stability and Growth } \\
\text { Pact } \\
\text { Preparation of treaty change to enable } \\
\text { the creation of a permanent crisis } \\
\text { management mechanism (and G-20 } \\
\text { summit in Seoul) }\end{array}$ \\
\hline
\end{tabular}

15 December 2010 16/17 December 2010: ordinary Euro- Implementation of the decisions of the pean Council meeting October European Council meeting:

ESM and treaty change

Climate change

\begin{tabular}{lll}
\hline 24 March 2011 & 24/25 June 2011: ordinary European & Situation in Libya \\
& Council meeting & Reform of the Stability and Growth \\
& Pact & Structural reforms in coordination of \\
& economic governance \\
& Decision on treaty change (Article 136 \\
& TFEU) and creation of ESM
\end{tabular}

26 October 201126 October 2011: informal European Decision on EFSF leverage

Council meeting and Eurozone summit

\begin{tabular}{lll}
\hline 2 December 2011 & $\begin{array}{l}\text { 8/9 December 2011: ordinary Euro- } \\
\text { pean Council meeting }\end{array}$ & $\begin{array}{l}\text { Measures to create a fiscal and political } \\
\text { union for stability }\end{array}$ \\
\hline 14 December 2011 & $\begin{array}{l}\text { 8/9 December 2011: ordinary Euro- } \\
\text { pean Council meeting }\end{array}$ & $\begin{array}{l}\text { Measures to create a fiscal and political } \\
\text { union for stability outside of EU } \\
\text { treaties due to Czech and UP opting- } \\
\text { out }\end{array}$ \\
\hline
\end{tabular}

$27 \mathrm{Feb} 2012$ 1/2 March 2012: ordinary European Financial aid for Greece through the Council meeting use of EFSF

Signing of fiscal compact at the European Council meeting

\begin{tabular}{lll}
\hline 27 June 2012 & $\begin{array}{l}\text { 28/29 June 2012: ordinary European } \\
\text { Council meeting }\end{array}$ & $\begin{array}{l}\text { Debate on Treaty to establish a Euro- } \\
\text { pean Stability Mechanism and ESM } \\
\text { Taxation of financial transactions }\end{array}$ \\
\hline 29 June 212 & $\begin{array}{l}\text { 28/29 June 2012: ordinary European } \\
\text { Council meeting }\end{array}$ & $\begin{array}{l}\text { Ratification of the Treaty to establish } \\
\text { a European Stability Mechanism and } \\
\text { ESM }\end{array}$
\end{tabular}

The discussion of European Council meetings in plenary plays an important role because plenary debates always take place in public, unless the public is excluded by a two-thirds majority of the Bundestag on request of one-tenth of its members or of the government. So if it is not only the control of government by parliament but also the extent to which 
parliament is seen by the citizens to carry out such actions which legitimates the government's activities in the eyes of the citizens, plenary debates are an important factor in the legitimation of such activities. Moreover, the public debate also exerts pressure on the government to explain its actions to parliament and thus serves as an important scrutiny instrument.

\subsubsection{The right to sanction the government}

The power of the Bundestag to sanction the Federal Government for misconduct is very limited. As was mentioned above, even when parliament has issued a (politically) binding statement of opinion, the government may deviate therefrom without facing any consequences. It merely has to explain its actions before ignoring the Bundestag's position. The most draconian sanction would of course be the dismissal of the government. Article 67(1) of the GG provides for the constructive vote of no confidence, whereby the Bundestag expresses its lack of confidence in the Chancellor by electing a successor with a majority of its members. However, the Bundestag can only dismiss the cabinet in its entirety; no individual ministerial accountability exists. If parliament disagrees with the actions of an individual minister, it has no means of dismissing the minister individually. The right to decide thereupon lies with the Chancellor (Article 64(1) of the GG). The Bundestag can merely threaten the Chancellor to dismiss the entire cabinet, should she refuse to remove the offending minister from cabinet. The effectiveness of such a threat and whether parliament would actually follow up on such a threat is, however, very questionable.

Another possibility of sanctioning the government is through parliament's budgetary rights. Article 110(2) of the GG states that the "budget for one or more fiscal years shall be set forth in a law enacted before the beginning of the first year and making separate provision for each year." This means that it is solely the competence of the legislature the Bundestag and the Bundesrat - to prepare the budget. This is also expressed in Article 114 of the GG, which provides that the Bundestag and the Bundesrat have the right (and the obligation) to monitor the execution of the budget by the government by means of a discharge. ${ }^{136}$ Thus, in case of misconduct, parliament may also refuse discharge to the government.

The parliamentary budgetary right generally serves as "an instrument of comprehensive parliamentary monitoring of the government" 137 and was the subject matter of a series of judgments handed down by the BVerfG. The basis for its argumentation is the principle of democracy that is contained in Article 38(1) of the GG, which, in the BVerfG's opinion, does not allow for the transfer of the responsibilities and competences of the Bundestag-

136 BVerfG, Judgment of 07 September 2011 - 2 BvR 987/10, para. 122.

137 Ibid. 
including its budgetary rights - to the European level to such an extent that it would violate the principle of democracy. ${ }^{138}$ This principle would be violated if the Bundestag were to waive its budgetary rights in such a manner that it would no longer be able to decide on the budget on its own responsibility in the future. ${ }^{139}$ The BVerfG considered parliament's budgetary right as a fundamental part of the ability of a constitutional state to democratically shape itself. ${ }^{140}$ Moreover, it serves as an instrument for monitoring the Federal Government. ${ }^{141}$ The Bundestag must fulfill its functions, including the budgetary one, as a representative body in its entirety, meaning through the participation of all of its members as opposed to (a group of) individual MdBs or the majority only. ${ }^{142}$ This prohibits the latter from transferring its budgetary rights in such a manner that budgetary decisions could be taken without its consent and the larger the amount in question, then the more effective the parliamentary right to approve, refuse and monitor must be. The Bundestag may not agree to any mechanisms with financial effects, which could result in incalculable burdens with budgetary significance, without obtaining prior mandatory consent. ${ }^{143}$ This latter requirement, as imposed by the BVerfG, ultimately led to the adoption of the ESMFinG and the StabMechG (see Section 4.3.3).

Hence, as no specific provisions exist with regard to the possibility of the Bundestag to sanction the government, it can only take recourse to the threat of a vote of no confidence or through vindication of its budgetary rights. By ensuring the participation of the Bundestag in any major budgetary decision, parliament's budgetary rights have an important legitimizing purpose, especially in crisis times, and they consequently constitute an effective control mechanism by preventing any decisions from being taken without parliamentary consent.

\subsection{Concluding REMARKS}

It was asked in this chapter whether or not, as well as to what extent, parliament, and in this chapter in particular the German Bundestag, is able to hold the government to account by means of exercising control over it. Here, political accountability involves two elements, namely the obligation to inform about and justify the exercise of political powers as well as subjecting the exercise of those powers to the threat of sanctions.

Overall, it can be said that, legally, the German Bundestag disposes over a very wide range of rights and powers, which have the purpose of ensuring its control over the gov-

138 BVerfG, 2 BvE 5/06, supra note 31, para. 175.

139 BVerfG, 2 BvR 987/10, supra note 136, para. 121.

140 Ibid., para. 122.

141 Ibid..

142 BVerfG, 2 BvE 8/11, supra note 89, paras. 101-102.

143 Ibid., para. 109. 
ernment. Article 23 of the German Basic Law and the provisions of the EUZBBG provide the Bundestag with very extensive rights in relation to EU matters. The government is obliged to inform parliament about such matters, the scope of which has been interpreted very broadly by the Bundesverfassungsgericht so as to include not only issues falling within the framework of the EU Treaties, but also intergovernmental matters relating thereto. This information right is complemented by its right to ask questions to the government, which the Bundestag, however, has mainly used in relation to domestic matters. The Bundestag has also established a strong system of parliamentary committees with a powerful European Affairs Committee, which plays a crucial role in monitoring the government's activities and, in addition, serves as a filter instance for the flood of information that is sent to parliament each year. Next to the EAC, the Bundestag can also rely on the expertise of the support staff working in the parliamentary administration - which even has its own department for EMU matters - and which is responsible for prioritizing the incoming information on EU affairs. But despite this legal framework that is intended to ensure that the Bundestag has full information on the activities of the Federal Government, the problem nevertheless remains that the Bundestag is still dependent on the latter to receive such information. Even if the government is obliged to transmit (virtually) all documents relating to the EU, it has failed to do so in a number of cases by referring to its core executive responsibilities, which has also led to complaints by parliamentarians.

Moreover, even though the Bundestag has the power to instruct the Federal Government as to its position in EU negotiations, this power does not guarantee that it will be successful in this endeavour. The government can ignore its mandate by simply providing for some sort of justification therefor. The most powerful weapon of the Bundestag remains the political weight of its instructions, resolutions and debates and the public effects thereof, if it does not want to avail itself of its ultimate right dismiss the government. As the latter option is a very radical one, it seems unlikely to happen, especially in the context of European matters. In fact, since no Eurosceptic party is represented in the Bundestag - or at least not until the 2017 Bundestag elections - the entire parliament has, in general, a rather pro-European attitude, as does the government which often searches for a consensus across all parties with matters pertaining thereto. ${ }^{144}$

Generally, the party system in parliament plays an important role for scrutiny purposes. Because the government holds an information advantage vis-à-vis the opposition parties, the latter are more likely have an incentive to reduce such an information advantage via parliamentary scrutiny than the majority parties supporting the government. ${ }^{145}$ As was indicated above, the danger of agency loss through information asymmetry is more salient

144 Auel, supra note 2, p. 19.

145 D. Finke, T. Dannwolf, "Domestic Scrutiny of European Union Politics: Between Whistle Blowing and Opposition Control”, (2013) European Journal of Political Research, pp. 716 and 734. 
in EU matters than in domestic issues; this problem is countervailed, to a large extent, by the existent institutional powers of the Bundestag and the accompanying obligations of the Bundesregierung. If in the past, the Bundestag has been accused of not fully availing itself of its scrutiny rights, ${ }^{146}$ it is now the case that the laws regulating such rights (and obligations) have been considerably strengthened following the entry into force of the Treaty of Lisbon and as a result of the judgments of the Bundesverfassungsgericht.

The Bundesverfassungsgericht has presented itself in its decisions as a vigorous defender of the rights of parliament and it has thus repeatedly pointed out to parliament of its failure to exercise the control rights and the obligations transferred to it in full manner. This occurred, for example, when the Bundestag tried to transfer some of its decision-making powers with regard to the EFSF to a special committee of nine members (Sondergremium), which the BVerfG considered to be an unnecessary limitation of its powers. Another example is the short amount of time which the Bundestag spends on deliberating crisis matters. The urgent nature of certain measures are not disputed, but it remains questionable whether parliament is able to adequately deal with, and thereby legitimize, the subject matter in such a short space of time, especially considering the typical complexity of these matters. So far, the Bundestag is yet to be accused of abusing its control rights; the problem rather seems to be the contrary. ${ }^{147}$

146 See, for example: C. Sprungk, "Ever More or Ever Better Scrutiny? Analysing the Conditions of Effective National Parliamentary Involvement in EU Affairs”, (2010) 14 European Integration online Papers (EIoP).

147 S. Hölscheidt, "Parlamentarische Kontrolle in der Eurokrise", in B. Eberbach-Born, S. Kropp, A. Stuchlik, W. Zeh (eds.), Parlamentarische Kontrolle und Europäische Union, Nomos: Baden-Baden, 2013, p. 123. 



\section{Chapter: The Irish Dáil ÉIreanN}

\subsection{INTRODUCTION}

After having dealt with the German Bundestag in the last chapter, this chapter will take a closer look at the Irish Dáil Éireann. The Irish parliament seems to be decidedly less involved in EU affairs when compared to its German counterpart, with the relationship between parliament and government in Ireland having been described as "a combination of neglect and ignorance." There are no constitutional or legislative provisions in Ireland that are comparable to Articles 23(2) and (3) of the German Basic Law, which respectively lay down the framework for the participation of parliament in matters concerning the European Union. ${ }^{2}$ This absence has not necessarily contributed to a strong institutional role for the Oireachtas in EU affairs. ${ }^{3}$ Instead, it was only in 2011, when the new government was elected, that some (informal) rules were introduced concerning the obligation of ministers to explain themselves before parliament, or one of its committees, in relation to EU affairs. Another problem is that in the Irish political system, which is based on an election system of proportional representation by single transferable vote (STV) in multiseat constituencies, members of parliaments are rewarded - and more importantly reelected - for the constituency work they do. ${ }^{4}$ By way of contrast, neither committee work nor engagement in EU affairs is recognized by the electorate, leading to a particularly high motivational problem in the context of the Irish parliament when it comes to EU matters. ${ }^{5}$

This chapter will take a closer look at how the Irish parliament, and more specifically the Irish Dáil Eireann, deals with scrutinizing the Irish government in relation to EU affairs. It will follow the same structure as the chapter on the German Bundestag. Thus, the first part will deal with parliament's right to demand information, including its right to pose parliamentary questions (Section 5.2.1), the Scrutiny Act 2002 and the European Union Act 2009 (Section 5.2.2) and the functioning of the committee system (Section

1 B. Laffan, J. O’Mahony, "Managing Europe From Home: The Europeanisation of the Irish Core Executive”, (2003) Report on the Irish Case Study, Dublin European Institute, National University of Ireland, p. 27.

2 E. Fahey, "Reflections on the Legal Role of the Irish Parliament (Oireachtas) in EU Affairs after Lisbon", (2010) EUI Working Papers MWP 2010/20, p. 9.

3 Ibid., p. 13.

4 G. Barrett, “Long Train Running: The Slowly Developed (and Slowly Developing) Role of Ireland's Oireachtas in EU Affairs", in C. Hefftler, C. Neuhold, O. Rozenberg, J. Smith (eds.), The Palgrave Handbook of National Parliaments and the European Union, Palgrave Macmillan: United Kingdom, 2015, p. 303; G. Barrett, "Reviewing the Role of the Oireachtas in European Affairs", (2010) IIEA Paper delivered on 5 May, 2010 to the Joint Oireachtas Sub-Committee on the Review of the Role of the Oireachtas on European Affairs, p. 11.

5 Barrett (2015), supra note 4, p. 303. 
5.2.3). The second part will deal with the (lack of a) scrutiny reserve in the Irish parliamentary system, as well as the role of the plenary in scrutinizing the actions of the government at EU level (Section 5.2.4). The third part will then briefly consider the power of parliament to sanction the government, before the chapter concludes with comparative remarks on the differences that exist between the German Bundestag and the Irish Dáil with regard to their roles in EU affairs.

\subsection{The Irish DÁIL ÉIREANN}

\subsubsection{The right to demand information}

While traditionally the Irish system has accorded a high degree of independence and autonomy to the government, as well as to the individual ministries, ${ }^{6}$ this does not mean that there are no formal channels for parliament to receive relevant information, even though such channels are not as extensively laid down as is the case in the German system. With regards to information concerning EU matters, this is typically the responsibility of the Joint Committee on European Union Affairs (see Section 5.2.3).

\subsubsection{The right to summon the government}

Article $28.8^{\circ}$ of the Irish Constitution states that every member of the government has the right to attend and be heard in each of the Houses of the Oireachtas, but there is no constitutional provision that explicitly stipulates the right of parliament to summon members of the government before the plenary. The Irish Constitution merely states that the "government shall be responsible to Dáil Éireann" (Article 28.4.1 $1^{\circ}$ of the Irish Constitution), which is put into effect by parliamentary questions and the committee system. For example, the committees have the right to ask a member of the government to appear before it in order to discuss the policy for which he or she is officially responsible (see Section 5.2.3.3). Since 2011, the Irish government has also committed, in its statement of purpose, to oblige all ministers to "appear before their respective committees or the Committee on European Affairs prior to travelling to Brussels for meetings of the Council where decisions are made" (see Section 5.2.3.3). ${ }^{?}$

6 Laffan, O'Mahony, supra note 1, p. 81.

7 Statement of Common Purpose of Irish Government, 2011, available at: $<$ https://www.taoiseach.gov.ie/eng/Publications/Publications_Archive/Publications_2011/Programme_for_Government_2011.pdf> (last retrieved on 9 October 2017). 


\subsubsection{The right to ask questions}

As is possible in the German Bundestag, the Irish parliament's most basic information right is the right to ask parliamentary questions. It allows members of parliament to seek specific information from the government and to scrutinize its behavior in relation thereto. ${ }^{8}$ The right of the Dáil and its members to ask questions to the government is laid down in the Oireachtas Standing Orders of 2016 (S.O.). ${ }^{9}$ S.O. 37(2) specifies that such question have as their purpose to "elicit information upon or to elucidate matters of fact or of policy." In general, questions should be kept as brief as possible and may be submitted either for written or oral reply. In 2013, an overall number of 50926 parliamentary questions were asked. $^{10}$

\subsubsection{Written questions}

Most of the questions that are submitted to members of the government are submitted for written reply. ${ }^{11}$ They are submitted in writing and within three days the answer must be provided in the Official Report of the Debates (S.O. 35(b) and 42(2)). The questions must relate to public affairs that are connected to the department in question (S.O. 36) and they may not ask for information that has already been provided within the previous two weeks, either in the context of another parliamentary question (oral or written) or a plenary debate (S.O. 37(4)). Furthermore, they cannot concern a subject which is scheduled to be discussed in the Dáil within that same week (S.O. 37(6)).

\subsubsection{Oral questions}

Questions for oral answers may be asked during the relevant question times. The sittings of the Dáil take place on Tuesdays, Wednesdays and Thursday, out of which 30 to 45 minutes per day are reserved for question time to the ministers (S.O. 38(1)(b) and (2)). Questions for oral answers, which are not nominated for priority, must be submitted four days in advance of the debate at which they are to be answered (S.O. 35). However, because ministers take turn to face question times, members of the Dáil (Teachta Dála, TD) must wait for the relevant minister's session in order for their question to be answered. ${ }^{12}$ In general, oral questions may not ask for information that has already been provided within

8 B. Chubb, The Government and Politics of Ireland, Stanford University Press: Stanford, USA, 1982, p. 216.

9 Dáil Éireann Standing Orders Relative to Public Business Together With Oireachtas Library and Research Service Rules 2016, as published in January 2016, available at: <www.oireachtas.ie/parliament/about/publications/standingorders/> (last retrieved on 10 October 2017).

10 Oireachtas website, Parliamentary Questions, available at: <www.oireachtas.ie/parliament/oireachtasbusiness/parliamentaryquestions $>$ (last retrieved on 15 May 2015).

11 M. Gallagher, "Parliament”, in J. Coackley, M. Gallagher (eds.), Politics in the Republic of Ireland, Routledge: United Kingdom, 2005, p. 227.

12 Ibid.; P. Mitchell, "Ireland: 'O What a Tangled Web...' - Delegation, Accountability and Executive Power", in K. Strom, W. Müller, T. Bergman (eds.), Delegation and Accountability in Parliamentary Democracies, Oxford University Press: New York, USA, 2006, pp. 431-434. 
the previous four months in response to an oral question or to a matter that has already been raised in plenary sittings (S.O. 37(3)).

The order of the questions to be asked to the ministers in each session is decided by a lottery (S.O. 39(2)) and the time allowed for each question may not exceed six minutes, with two minutes reserved for the initial ministerial reply and one minute for each supplementary question or reply thereto (S.O. 40(2)(a)). These time constraints mean, as a consequence, that not every question can be answered on that day. This is why opposition TDs often submit similar questions in order to raise the chances of their question being asked. ${ }^{13}$ Each TD may only ask a maximum of two questions per day to the minister in question (S.O. 40(1)(ii)) and if identical questions are asked on the same day, then only one of such question will be posed (S.O. 40(1)(v) and (vi)). Questions may be nominated for priority by a TD from the opposition party, in which case it will be put on the order before all other questions. The number of such questions may not be more than five per day (S.O. 41(1)) and the time allowed for each question is six minutes, including two minutes for the initial ministerial reply (S.O. 41(2)(a)). Any question that could not be answered on the day due to a lack of time may either, upon request of the person posing the question, be asked on the next day or be answered in the Official Report of the Debates (S.O. 42(3)). Additionally, answers to oral questions that require a lengthy reply are provided in the Official Report (S.O. 42(4)).

Special question times, which may not last more than 45 minutes each day, are set aside for the Prime Minister and they take place on Tuesdays and Wednesdays (S.O. 38(1)(a) and 39(1)). Questions addressed to the Prime Minister are put on the Order Paper before questions to other members of the government of that same day. Questions that could not be answered on Tuesdays are dealt with on the next day and are dealt with before all other questions (S.O. 39(1)).

As was mentioned above, TDs may follow up a minister's reply with supplementary questions for the "further elucidation of the information requested" (S.O. 44). This does not mean, however, that the minister is obliged to fully answer a question or a supplementary question. ${ }^{14}$ In fact, Gallagher notes that it is not the goal of either the opposition or the governmental ministers to reveal all information during question times; instead the opposition's main intention is to embarrass the government through its questioning, which the latter in turn wants to prevent. ${ }^{15}$ Thus, ministerial replies do not have to be helpful or informative, so long as they are not untruthful. ${ }^{16}$ Nor will ministers disclose any information in their answers, unless a TD has specifically asked for that information. ${ }^{17}$ But even in such

13 Gallagher, supra note 11, p. 228.

14 Mitchell, supra note 12, pp. 431-434.

15 Gallagher, supra note 11, p. 228.

16 Ibid.

17 Ibid. 
a case there is no rule that legally forces the minister to give an answer to the question at hand, and there is no power for the chair of the Dáil to force him to do so. ${ }^{18}$ Politically speaking, however, there is still a certain pressure on ministers to give a satisfactory reply. As question time is covered by the media, not answering a critical question could possibly prove to be even more harmful for the government than answering it in a satisfactory manner. ${ }^{19}$

\subsubsection{The participation of the Dáil Éireann in European Union matters}

\subsubsection{The European Scrutiny Act 2002}

The European Union Scrutiny Act (hereinafter: Scrutiny Act) was adopted in October 2002 as a response to the failure of the Nice referendum, during which "the weakness or perceived absence of parliamentary scrutiny of EU business was highlighted as a serious problem. ${ }^{20}$ After the ratification of the Treaty of Nice was rejected in Ireland, the Irish government wanted to give the impression in the citizenry that it was taking the scrutiny of EU matters seriously. ${ }^{21}$ While new scrutiny measures have been gradually introduced on an informal basis, the government still wished to codify these informal practices in statute. $^{22}$ For that reason, the adoption of the Scrutiny Act 2002 is considered by some as a matter of political calculation rather than one of actual legal necessity. ${ }^{23}$

Under Section 2(1) of the Scrutiny Act, the government must forward any proposed measure to both Houses of the Oireachtas. This must be done "as soon as practicable" and it must be accompanied by a statement from the minister containing, at least, the content, purpose and implications of the measure for Ireland. Here, a 'measure' is understood as a regulation or directive adopted under the TFEU, a decision adopted under Articles 28 or $29 \mathrm{TEU}$, or an act other than a regulation, directive or decision which requires the prior approval of both Houses of the Oireachtas in accordance with Article 29.4. $7^{\circ}$ and $8^{\circ}$ of the

18 Mitchell, supra note 12, pp. 431-434.

19 Ibid.

20 Laffan, O’Mahony, supra note 1, p. 95.

21 L. O'Hegarty, "Parliamentary Scrutiny of European Affairs in Ireland - The European Affairs Committee, the Scrutiny Committee and the European Union (Scrutiny) Act 2002", in G. Barrett (ed.), National Parliaments and the European Union: The Constitutional Challenge for the Oireachtas and Other Member State Legislatures, Clarus Press: Ireland, 2008, p. 280; G. Barrett, "Oireachtas Control over Government Activity at European Union Level: Reflections on the Historical Context and the Legal Framework”, in G. Barrett (ed.), National Parliaments and the European Union: The Constitutional Challenge for the Oireachtas and Other Member State Legislatures, Clarus Press: Ireland, 2008, p. 159.

O’Hegarty, supra note 21, p. 281. 
Irish Constitution (Section 6 of the European Union Act 2009, ${ }^{24}$ amending Section 1 of the Scrutiny Act 2002).

In practice, the government used to forward the required documents to the Joint Committee on European Union Affairs, which had the task of prioritizing the incoming proposals according to their significance "in order to ensure that adequate time and attention can be devoted to these. ${ }^{25}$ Where proposals were found to require further scrutiny, they were transmitted to the relevant sectoral committee for further consideration. ${ }^{26}$ With the beginning of the new parliamentary session in 2011, this task was, for the first time, streamlined to the respective sectoral committees. ${ }^{27}$

Section 2(2) of the Scrutiny Act 2002 requires every minister that performs functions in relation to a proposed measure to have regard to "any recommendations" that have been adopted by parliament, or one of its committees with regard thereto. This is, however, not a legally binding obligation on the ministers to actually follow the parliament's recommendations in Council negotiations. ${ }^{28}$ Moreover, at least twice a year, every minister of the government is obliged to submit a report to both Houses of parliament with regards to any measure, proposed measure and any other developments concerning the EU that falls within their remit (Section 2(5) Scrutiny Act 2002). Section 5 of the Scrutiny Act 2002 requires the Irish government to submit an annual report to both Houses on EU developments. ${ }^{29}$ Such reports, however, have generally been late and they are not frequently debated in parliament, rendering them a scrutiny tool with only very limited effectiveness. ${ }^{30}$

However, there are two exceptions to the obligations under Sections 2(1) and 2(2) of the Scrutiny Act 2002. Firstly, for the purposes of Section 2(3) of the Scrutiny Act 2002, neither Section 2(1) nor Section 2(2) of the Scrutiny Act 2002 is applicable if the minister deems there to be 'insufficient time' for carrying out such obligations. However, the act does not provide a definition as to what is considered to be 'insufficient time'. It seems to be left to the individual minister to decide whether a measure is of such urgency that it justifies the exclusion of parliament ex ante, which in turn does not exclude the possibility that this power will be abused. ${ }^{31}$ If, in such a case, a proposed measure is adopted by an EU institution without having been forwarded to the Irish parliament, the minister must ensure that a text of the measure is laid before both Houses of the Oireachtas, together with a statement on its implications for Ireland, the circumstances of its adoption and any

24 European Union Act 2009, S.I. 2009/33, available at: <www.irishstatutebook.ie/2009/en/act/pub/0033> (last retrieved on 15 May 2015).

25 O'Hegarty, supra note 21, p. 282.

26 Ibid.

27 Barrett (2015), supra note 4, p. 296.

28 Ibid., p. 292.

29 Section 4 of the Scrutiny Act amends the European Communities Act of 1972 in this regard.

30 Laffan, O’Mahony, supra note 1, p. 27.

31 Fahey, supra note 2, p. 89. 
other appropriate information (Section 2(4) of the Scrutiny Act 2002). Secondly, Sections 2(1) and 2(2) of the Scrutiny Act 2002 are not applicable in cases where a proposed measure is considered confidential according to the opinion of the minister (Section 3(1) of the Scrutiny Act 2002). In such cases, the minister, in accordance with Section 3(2) of the Scrutiny Act 2002, "may make a report to either or both Houses of the Oireachtas or to a committee of either or both such Houses in relation to the proposed measure as he or she deems appropriate in the circumstances".

\subsubsection{The European Union Act 2009}

The European Union Act 2009 lays down provisions concerning Ireland's membership in the European Union. It amends the European Communities Acts 1972 to 2007. Together, they constitute the European Communities Acts 1972 to 2009. ${ }^{32}$ They also contain some provisions on the involvement of the Irish parliament in EU matters, but these provisions seem rather limited.

Section 4(1) of the European Communities Act 1972 (hereinafter: the 1972 Act) states that regulations under the Act have statutory effect only where they are confirmed by parliament within six months, unless they are regulations merely revoking previous regulations. Sections 3A and 2(a) of the European Communities Act 2007 (hereinafter: the $2007 \mathrm{Act}$ ) provide that regulations making "provisions for offences under the regulations to be prosecuted on indictment" must be presented to each House of parliament as soon as it is made, which then both have 21 days to pass a resolution annulling the regulation. Section 5 of the 1972 Act requires the government to "make a report twice yearly to each House of the Oireachtas on developments in the European Communities."

The European Union Act 2009 introduced provisions on the involvement of the Irish parliament in matters concerning the passerelle clause, the principle of subsidiarity and family law with cross-border implications. Section 7(1) of the European Union Act 2009 states that both the Dáil and the Seanad may, within six months of receiving the notification, pass a resolution opposing the adoption of a decision that has been made under Article 48(7) TEU. This passerelle clause allows the European Council to adopt a decision to change the voting procedure in the Council of Ministers from unanimity to qualified majority, or to change the legislative procedure from a special legislative procedure to the ordinary legislative procedure. It is the Joint Committee on European Affairs that has the task of considering such decisions by the European Council.

Section 7(2) of the European Union Act 2009 allows both Houses of the Oireachtas to oppose decisions concerning family law with cross-border implications. The time limit is

32 European Communities Act 1972, S.I. 1972/27, available at: <www.irishstatutebook.ie/1972/en/act/pub/0027> (last retrieved on 15 May 2015); European Communities Act 2007, S.I. 2007/18, available at: <www.irishstatutebook.ie/2007/en/act/pub/0018> (last retrieved on 15 May 2015); European Union Act 2009, S.I. 2009/33, available at: <www.irishstatutebook.ie/2009/en/act/pub/0033> (last retrieved on 15 May 2015). 
also six months. Under Section 7(3) of the European Union Act 2009, both the Dáil and the Seanad may draft a reasoned opinion on a legislative proposal, if it considers that the latter does not comply with the principle of subsidiarity as stipulated by Article 6 of Protocol $\mathrm{No}^{\circ} 2$ on the application of the principles of subsidiarity and proportionality. Additionally, it is for the Joint Committee on European Affairs to form a reasoned opinion on such an issue, which it then submits to the Dáil by means of a report. Section 7(4) of the European Union Act 2009 provides parliament with the ability to start proceedings to seek a review of the act in question before the ECJ.

Thus, the degree of involvement of the Dáil in EU matters as foreseen by statute is not very high. Instead, it is limited only to very specific areas.

\subsubsection{The ability of the Dáil Éireann to process information}

As in the case of the German Bundestag, the Irish Dáil Éireann can effectively control the Irish government only when it is able to process all the information it has received. ${ }^{33}$ Thus, what is important is not only the amount and the timing of the reception of documents concerning EU matters, but also the mechanisms that have been installed by parliament to filter out information that is important to them. ${ }^{34}$ Similar to what is the case in the German Bundestag, in the Irish parliament this task also falls to its committees.

\subsubsection{The Irish committee system}

In the Irish committee system, four different forms of parliamentary committees exist: the standing committee, the select committee, the joint committee and the special committee. With regards to the first of these, the Standing Orders of each House of the Oireachtas may provide for the automatic creation of a standing committee at the beginning of a new legislative period, such as was the case for the Committee of Public Accounts. ${ }^{35}$ Special committees, by way of contrast, can be created for the sole purpose of considering a specific bill. ${ }^{36}$ Both Houses of the Oireachtas may also appoint their own select committees, in which the members come from their own House only. Joint committees constitute a merger of two select committees from both the Dáil and the Seanad.

33 K. Auel, "Democratic Accountability and National Parliaments: Redefining the Impact of Parliamentary Scrutiny in EU Affairs", (2007) 13 European Law Journal, p. 489.

34 European Parliament, Directorate-General for Internal Policies, Policy Department Citizens' Rights and Constitutional Affairs, "Democratic Control in the Member States of the European Council and the Eurozone Summits", Study (2013), p. 17.

35 Oireachtas website, available at: <www.oireachtas.ie/ViewDoc.asp?fn=\%2Fdocuments\%2Fleaflet\%2Fcomm.htm> (last retrieved on 15 May 2015).

Ibid. 
Most committee sessions are held in public. ${ }^{37}$ The committee system in the Oireachtas, as well as its role in scrutinizing the government, was rather weak until the $1980 \mathrm{~s} .{ }^{38}$ Originally, there was the Westminster view that the government should be able to govern without too much interference from parliament, but the latter's powers have since been strengthened. ${ }^{39}$ Each government department is mirrored by a sectoral committee, appointed separately by the Dáil and the Seanad and subsequently merged into a joint committee. ${ }^{40}$ An example of such a joint committee is the Oireachtas Joint Committee on European Union Affairs.

\subsubsection{The Joint Committee on European Union Affairs}

The Joint Committee on European Union Affairs (hereinafter: the Joint Committee) is responsible for EU matters. The Joint Committee on European Union Affairs, as it currently exists, was established in June 2011, ${ }^{41}$ and consists of the Select Committee on European Union Affairs of the Dáil and the Select Committee on European Union Affairs of the Seanad. It has fourteen members, of which nine are drawn from the Dáil Select Committee ${ }^{42}$ and five from the Seanad Select Committee. ${ }^{43}$ Its task is to deal with any matter arising from Ireland's EU membership and Ireland's adherence to the TEU and TFEU, which is not referred to another committee. ${ }^{44}$

In July 1973, when Ireland became a Member State of what was then the European Communities, the Joint Oireachtas Committee on the Secondary Legislation of the European Communities was created. ${ }^{45}$ It was comprised of members of both the Dáil and the Seanad, the composition of which mirrored the composition of the political parties in both Houses. ${ }^{46}$ Initially the committee was not intended to have or to ever receive the power to exert serious control over the Irish government. Rather it was the intention for this committee to play only a minor role, not least because it did not have the sufficient resources necessary

37 Ibid.

38 P. Conlan, "Ireland: Enhanced Parliamentary Scrutiny of European Affairs: But is it Effective?", in J. O'Brennan, T. Raunio (eds.), National Parliaments within the Enlarged European Union - From 'Victims' of Integration to Competitive Actors?, Routledge: United Kingdom, 2007, p. 180; Mitchell, supra note 12, p. 434; O’Hegarty, supra note 21, p. 279.

39 Mitchell, supra note 12, p. 434.

40 O'Hegarty, supra note 21, p. 279.

41 Joint Committee on European Union Affairs, Work Programme 2014, (February 2014) available at: $<$ www.oireachtas.ie/parliament/media/committees/euaffairs/JCEUA-Work-Programme-2014.pdf >(last retrieved on 15 May 2015).

42 Paragraph 1 of the Orders of Reference of the Dáil Select Committee on European Union Affairs of 8 June 2011.

43 Paragraph 1 of the Orders of Reference of the Seanad Select Committee on European Union Affairs of 16 June 2011.

44 Paragraph 1 of the Orders of Reference of the Dáil Select Committee on European Union Affairs and the Orders of Reference of the Seanad Select Committee on European Union Affairs.

45 Conlan, supra note 38, p. 180; Barrett (2008), supra note 21, p. 157.

46 Barrett (2008), supra note 21, p. 157. 
to deal with the "unrealistically large workload" and because of "a general lack of regard for its output." ${ }^{\prime 7}$ Even though the committee allowed its members to acquire some expertise in EU matters, this advantage was limited insofar as membership only lasted for the duration of the relevant parliamentary term. ${ }^{48}$

In 1993, the Joint Oireachtas Committee on Secondary Legislation then briefly became a part of the Foreign Affairs Committee before the Joint Committee on European Affairs was created in 1995. This Joint Committee was given wider powers than the earlier Joint Committee on Secondary Legislation, apparently due to the parties holding a more positive attitude towards the committee system. ${ }^{49}$ In 2002 a sub-Committee on European Scrutiny was created to deal with scrutiny work, such as the sifting and reviewing of EU documents on the basis of the Scrutiny Act 2002, ${ }^{50}$ until a separate committee was created for this purpose in October 2007, namely the Joint Committee on European Scrutiny. Until 2011, it was the Joint Committee on European Scrutiny that carried out the scrutiny tasks set out in the Scrutiny Act 2002, before it then became the Joint Committee on European Union Affairs.

In that same year, the scrutiny process of EU matters in the Oireachtas committees was mainstreamed to the sectoral committees for the first time. ${ }^{51}$ This meant that EU matters were no longer considered in a centralized European Affairs Committee, but rather they were considered in the different sectoral committees, which have expertise in the relevant subject area. This decentralization of EU scrutiny allows the Joint Committee on European Union Affairs, as the only committee dealing exclusively with EU matters, ${ }^{52}$ to focus on "matters concerning the strategic direction of the EU, as well as those of a crosssectoral nature." ${ }^{33}$

Thus, it is the sectoral committees that decide which proposals merit a more in-depth review and that engage with the ministers of the government department that they shadow. ${ }^{54}$ The Joint Committee, by way of contrast, assumes more of an oversight function (at least

47 Ibid.

48 Ibid.

49 Ibid., p. 158.

50 K. Meenan, "What is the Role of a Committee on European Affairs?”, in G. Barrett (ed.), National Parliaments and the European Union: The Constitutional Challenge for the Oireachtas and Other Member State Legislatures, Clarus Press: Ireland, 2008, p. 311.

51 Oireachtas website, Consideration of EU Matters by Sectoral Committees, available at: $<$ www.oireachtas.ie/parliament/oireachtasbusiness/www.oireachtas/committees/europeanunion/scrutinyprocess $>$ (last retrieved on 15 May 2015); Barrett (2015), supra note 4, pp. 295-296.

52 Barrett (2015), supra note 4, p. 295.

53 Joint Committee on European Union Affairs EU Scrutiny Work Programme 2014: Joint Committee's Priorities, available at: <www.oireachtas.ie/parliament/media/committees/euaffairs/Oireachtas-EU-ScrutinyPriorities-2014-FINAL.pdf> (last retrieved on 18 May 2015), p. 4.

Oireachtas website, supra note 51. 
theoretically $)^{55}$ and it is supposed to ensure that EU affairs are sufficiently scrutinized at EU level. ${ }^{56}$

In practice, however, this system is beset with two deficiencies. First of all, the sectoral committees do not tend to spend much time on the scrutiny of EU matters, as they tend to give preference to domestic matters, which have more political and electoral value for them. Thus, EU matters are often dealt with briefly at the beginning of the committee meeting, "normally by a decision that a clearly predetermined list of measures warrants no further scrutiny", before the committee then turns to discuss more important matters. ${ }^{57}$ Secondly, the degree of actual oversight powers that are endowed on the Joint Committee over the scrutiny of EU matters by the sectoral committees seems to be questionable. Thus, the Joint Committee itself complained in its 2014 report that it was "underused" and that it oversight powers were very "limited." 58 According to its report, the coordination between the different kinds of committees was insufficient, as such powers only existed on the administrative level, thereby leading to "a lack of ownership of EU scrutiny in the Oireachtas and a lack of visibility." ${ }^{\prime 9}$ The problem is that there is no obligation for the sectoral committees to scrutinize EU proposals until a certain deadline; similarly there is no obligation for them to report back to the Joint Committee about their scrutiny actions. This means that the Joint Committee will often be unaware of the latter, which is also the same with regard to opinions that have been rendered by the sectoral committees within the political dialogue with the European Commission or the subsidiarity control. For that reason, the Joint Committee considers that "there is a need for a European Affairs Committee that plays a coordinating and oversight role, while also engaging in some scrutiny activity, on a formal basis." 60

In 2010, a Joint sub-Committee on the Review of the Role of the Oireachtas in European Affairs was created with the purpose of reviewing the implementation of the Treaty of Lisbon through the European Union Act 2009 and to provide a report to both Houses of parliament within six months. ${ }^{61}$ The committee met a total of eleven times, with five hearings being held in public, and it also heard the opinions of practitioners working in

55 Joint Committee on European Union Affairs, Assessment of Current Structures for Oireachtas Scrutiny of EU Affairs, (April 2014) available at: <www.oireachtas.ie/parliament/media/committees/euaffairs/Reviewof-Structures-for-Oireachtas-Scrutiny-of-EU-Affairs_JCEUA-Report_April-2014.pdf> (last retrieved on 18 May 2015), p. 5.

56 Laffan, O’Mahony, supra note 1, p. 27.

57 Barrett (2015), supra note 4, p. 296.

58 Joint Committee on European Union Affairs, supra note 55, p. 5.

59 Ibid.

60 Ibid.

61 Joint Committee on European Scrutiny, Eighth Annual Report on the Operation of the European Union (Scrutiny Act) 2002, (January 2011) available at: <www.oireachtas.ie/viewdoc.asp?DocID=17522\& CatID=78\&StartDate=01\%20January\%202011\&OrderAscending=0 $>$ (last retrieved on 18 May 2015), pp. $9-10$. 
EU affairs and in the area of parliamentary control. ${ }^{62}$ More recently, a sub-Committee on the Referendum on the Intergovernmental Treaty on Stability, Coordination and Governance in the Economic and Monetary Union was created in order to deal with the Fiscal Compact. For that purpose, the sub-Committee also invited speakers from civil society to participate in the discussions. ${ }^{63}$

\subsubsection{The powers of the Joint Committee}

The task of the Joint Committee used to be to consider all documents relating to the European Union and to filter out those that it considered to be important. Every two weeks, a sub-committee thereof sifted through the documents in order to identify those that it regarded as important enough to merit parliamentary scrutiny. ${ }^{64}$ Since 2011 , when the scrutiny process was decentralized, EU documents are now sent to the office of the Deputy Speaker of the Dáil. An EU Coordination Unit is then responsible for forwarding the documents to the relevant sectoral committees, which then decide which documents require further scrutiny and those which do not. Those relating to the 'big picture' or to cross-sectoral issues are sent to the Joint Committee on European Affairs, for example the Multiannual Financial Framework. ${ }^{65}$

According to the Joint Committees Orders of Reference, documents to be considered include the consideration of the EU Commission's strategic planning documents and the cross-sectoral policy development at EU level, the discussion of matters listed on the agenda of the General Affairs Council of Ministers as well as their outcome and the consideration of selected regulations and instruments that are necessitated by Ireland's membership of the European Union. ${ }^{66}$ It also deals with notifications that have been referred by the Dáil under Standing Order 115(1)(a), ${ }^{67}$ notifications of proposals for Treaty amendments under Article 48(2) TEU, notifications of applications for EU membership under Article 49 TEU and any other matter as may be referred to it by the Dáil or the Seanad. ${ }^{68}$ Where necessary, the Joint Committee may also ask for an explanatory memorandum from the relevant

62 Ibid.

63 European Parliament, Directorate-General for Internal Policies, Policy Department Citizens' Rights and Constitutional Affairs, "Democratic Control in the Member States of the European Council and the Eurozone Summits”, In-depth reports on 12 Member States (Annex) (2013), p. 17.

64 Laffan, O’Mahony, supra note 1, pp. 95-96; M. Murphy, "Reform of Dáil Éireann: The Dynamics of Parliamentary Change”, (2006) 59 Parliamentary Affairs, p. 448.

65 Barrett (2015), supra note 4, p. 292.

66 Paragraph 5 of the Orders of References of the Dáil Select Committee on European Union Affairs; Paragraph 2 of the Orders of References of the Seanad Select Committee on European Union Affairs.

67 S.O. 115(1)(a) states: "The Dáil may empower a Select Committee to consider such notifications under(a) the third subparagraph of Article 48.7 of the Treaty on European Union (general passerelle: change from unanimity to qualified majority or from special legislative procedure to ordinary legislative procedure) as applied by section 7(1) of the European Union Act 2009."

68 Paragraph 5 of the Orders of References of the Dáil Select Committee on European Union Affairs; Paragraph 2 of the Orders of References of the Seanad Select Committee on European Union Affairs. 
governmental department explaining the importance and implications of the EU proposal at hand for Ireland. ${ }^{69}$ While committee meetings are normally held in public, ${ }^{70}$ they can also be held in private, if a particularly sensitive issue is to be debated. ${ }^{71}$

Paragraph 6 of the Dáil Orders of References and paragraph 3 of the Seanad Orders of References oblige the Joint Committee to report to both Houses of the Oireachtas on the operation of the 2002 Scrutiny Act, a task that previously belonged to the Joint Committee on European Scrutiny. Such a report normally includes statistics concerning the annual number of scrutinized proposals, contributions sent to the EU institutions and reasoned opinions agreed in plenary. It also lists the statistics for the sectoral committees and includes a "qualitative assessment of the operation" of the Scrutiny Act 2002 as well as potential recommendations for improvement thereto. ${ }^{72}$ In drafting the report, the Joint Committee may also take external views into account as to the effectiveness of the parliamentary scrutiny process in relation to EU affairs. It can also call for a debate on the report in the Houses of the Oireachtas. ${ }^{73}$

By way of contrast to the sectoral committees, the Joint Committees does not receive the half-yearly reports on EU measures and developments from the respective departments. ${ }^{74}$ The committees may furthermore invite ministers from the relevant departments to attend committee meetings and to discuss such reports, even though this right has not been consistently used across all committees. ${ }^{75}$ The reports serve as an instrument for the individual committees to review EU developments in their key policy areas within the last six months, as well as to examine their own engagement in scrutinizing EU measures falling within the remit of the departmental minister that they are shadowing. ${ }^{76}$ However, it is often the case that reports are submitted late by the departments, or dealing with the reports is delayed in the committees due to its scheduling, which according to the Joint Committee means that "the interaction on the report can lose some impact as the material is outdated." ${ }^{77}$

Under paragraph 7 of the Orders of Reference of the Dáil Select Committee, ${ }^{78}$ the Joint Committee has the powers that are defined in S.O. 85, S.O. 114, S.O. 115(1) and S.O. 116. ${ }^{79}$

69 Laffan, O’Mahony, supra note 1, pp. 95-96; Murphy, supra note 64, p. 448.

70 Oireachtas website, available at: <www.oireachtas.ie/ViewDoc.asp?fn=\%2Fdocuments\%2Fleaflet $\% 2 \mathrm{~F}$ comm.htm $>$ (last retrieved on 18 May 2015).

71 Laffan, O’Mahony, supra note 1, pp. 95-96; Murphy, supra note 64, p. 448.

72 Joint Committee on European Union Affairs, supra note 41, p. 11.

73 Ibid.

74 Joint Committee on European Union Affairs, supra note 55, p. 8.

75 Ibid.

76 Ibid.

77 Ibid.

78 This paragraph is mirrored by paragraph 4 of the Orders of Reference of the Seanad Select Committee on European Union Affairs.

79 Previously S.O. 83, 105, 106(1)(a) and 107. 
Such powers include the power to take and publish oral and written evidence, to invite and accept written submissions from interested persons or bodies, as well as the power to appoint sub-Committees and to delegate any of its powers to such sub-Committees (S.O. 85(1), (2) and (3)). According to S.O. 85(4), the Joint Committee may also draft recommendations for legislative change and for new legislation, as well as consider and report to the Dáil on EU legislative proposals that are referred to it by other committees.

It may, moreover, require a member of the government to come before the Joint Committee to discuss the policy for which he or she is officially responsible (S.O. 85(5)) or to discuss proposed primary or secondary legislation before their publication (S.O. 85(6)). Where the minister refuses to appear before the committee, he or she must submit written reasons therefor to the committee, which can refer those to the Dáil. The members of the government may also be asked to attend a committee meeting in order to discuss the policy for which he or she is responsible (S.O. 85(5) and (6)). It also has the power to compel "principal office holders in bodies in the State which are partly or wholly funded by the State or which are established or appointed by members of the Government or by the Oireachtas" to attend its meetings (S.O. 85(7)). And lastly, S.O. 85(8) and (9) allow the Joint Committee to hire persons with specialist or technical knowledge for assistance in considering particular matters, as well as to undertake travel under certain circumstances.

S.O. 114 gives the Joint Committee the power to form a reasoned opinion that a draft EU legislative act does not comply with the principle of subsidiarity in accordance with Article 6 of Protocol $\mathrm{No}^{\circ} 2$ on the application of the principles of subsidiarity and proportionality. ${ }^{80}$ In forming such a reasoned opinion, the committee must consult with other relevant committees, as well as any relevant stakeholders. Where it finds the subsidiarity principle to have been breached, it must submit a reasoned opinion to this effect by way of a report to the Dáil (S.O. 114(3)). Similarly, S.O. 116 gives the Joint Committee the power to consider, in accordance with Article 8 of Protocol $\mathrm{No}^{\circ} 2$, whether any act of an EU institution has infringed the principle of subsidiarity. It must also consult with any other relevant committees and stakeholders and submit a report to the Dáil if it wants to initiate proceedings against the act concerned before the ECJ (S.O. 116(2)).

80 Article 6 of Protocol $\mathrm{No}^{\circ} 2$ states: "Any national Parliament or any chamber of a national Parliament may, within eight weeks from the date of transmission of a draft legislative act, in the official languages of the Union, send to the Presidents of the European Parliament, the Council and the Commission a reasoned opinion stating why it considers that the draft in question does not comply with the principle of subsidiarity. It will be for each national Parliament or each chamber of a national Parliament to consult, where appropriate, regional parliaments with legislative powers. If the draft legislative act originates from a group of Member States, the President of the Council shall forward the opinion to the governments of those Member States. If the draft legislative act originates from the Court of Justice, the European Central Bank or the European Investment Bank, the President of the Council shall forward the opinion to the institution or body concerned." 
Under S.O. 115(1)(a), the Joint Committee may consider - as is applied by Section 7(1) of the European Union Act 2009 - notifications relating to the so-called passerelle clause under Article 48(7) TEU, which allows the European Council to adopt a decision to change the voting procedure in the Council of Ministers from unanimity to qualified majority or to change the legislative procedure from a special legislative procedure to the ordinary legislative procedure. In any such case, the decision must be notified to national parliaments, which can then make known their opposition within six months, in which case the decision cannot be adopted (Article 48(7) TEU). Paragraph 8 states that the Joint Committee also has the power to "make recommendations to the Minister for Foreign Affairs and Trade (or Minister of State) on European Union matters."

It is also possible for MEPs elected from constituencies in Ireland, members of the Irish delegation to the Parliamentary Assembly of the Council of Europe and, at the invitation of the committee, members of the EP to attend meetings of the Joint Committee. They do not have the right to vote or to move, however ( $\$ 9$ Orders of Reference of the Dáil Select Committee; $\$ 6$ Orders of Reference of the Seanad Select Committee). The Joint Committee, moreover, represents both Houses of the Oireachtas at the Conference of European Affairs Committees in the EU (COSAC), on which it must report back to both Houses ( $\$ 10$ Orders of Reference of the Dáil Select Committee; $\$ 7$ Orders of Reference of the Seanad Select Committee). Paragraph 11 of the Orders of Reference of the Dáil Select Committee and paragraph 11 of the Orders of Reference of the Seanad Select Committee state that the chairman of the Joint Committee, who must be a member of the Dáil Éireann, is also the chairman of the Dáil Select Committee.

\subsubsection{Number of documents considered by the Joint Committee}

In 2010, the Joint Committee on European Union Affairs considered a total of 441 documents. ${ }^{81}$ Out of those 441 documents, the Joint Committee only found 21 documents amounting to $5 \%$ of the overall number of submitted proposals - to be significant enough to Irish interests to require further scrutiny. Ten of those documents were forwarded to sectoral committees for that purpose, while eleven were sent to the Joint Committee on European Scrutiny. ${ }^{82}$ Another 67 documents were sent to sectoral committees for more information, about a third of which went to the Joint Committee on Justice, Equality, Defence and Women's Rights, but for the majority of the proposals there was no need for further scrutiny, according to the Joint Committee. ${ }^{83}$

81 Joint Committee on European Scrutiny, supra note 61, p. 11.

82 Ibid., pp. 12-13.

83 Ibid. 


\subsubsection{The role of the committees in scrutinizing (European) Council meetings}

The Joint Committee plays no role in scrutinizing the European Council meetings, which is the task of the Dáil plenary session. ${ }^{84}$ One exception from that rule came in December 2011 when the Second Secretary General of the Department of the Taoiseach attended the meeting of the Joint Committee, informed it on the results of the Euro summit concerning the Fiscal Compact and the need for stronger coordination of economic policies and answered the questions of the committee members thereon. ${ }^{85}$

The committees, however, do play a role in scrutinizing their respective ministers before Council meetings, at least in theory. In 2011, the incoming government made a commitment obliging all ministers to appear before the respective sectoral committees or Joint Committees before Council meetings. But in practice, this has not been the case. ${ }^{86}$ The Minister of State for European Affairs (who belongs to the Taoiseach department) has been the only minister to regularly appear before the Joint Committee prior to General Affairs Council meetings. ${ }^{87}$ Such appearances also include the provision of written statements to the committee, ${ }^{88}$ and generally a wide range of issues is dealt with in such meetings. ${ }^{89}$

Other government ministers, by way of contrast, do not appear before their respective committees as often or as regularly, either before or after Council meetings. ${ }^{90}$ This seems to be due to both the heavy workload of the committees with regard to domestic issues and the busy schedules of the ministers themselves. ${ }^{91}$ This combination results in a situation whereby there is very little incentive for the ministers to appear before the committees, but also little incentive or possibility for committee members to force them to appear. ${ }^{92}$ In fact, the degree to which committee members are interested in scrutinizing the actions of the government in Council negotiations, as well as the degree of their preparation to do so, tends to vary. ${ }^{93}$

And even when the minister does appear before a committee prior to a Council meeting, there is no obligation on the minister to come back afterwards - not even in the Joint Committee. ${ }^{94}$ This means that the ministers do not have to justify and explain their actions in the Council in the committees ex post and whether and how they have tried to enforce the committee's views at EU level. Such a lack of 'feedback' by the ministers may also be

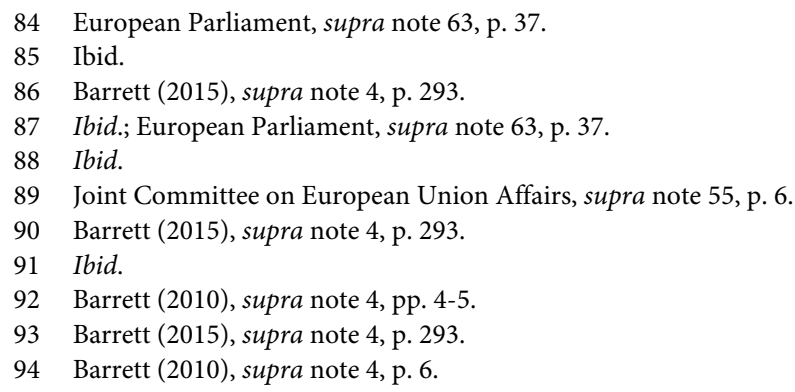


discouraging for members of parliament in that they do not learn whether and to what extent their deliberations had an impact on the outcome of the Council negotiations. ${ }^{95}$ The lack of any possibility for the committees to hold the ministers to account in a face to face manner has traditionally led to document scrutiny being considered as important as holding ministers accountable for Council negotiations, even though Barrett asserts that the Oireachtas is not particularly good at doing that either. ${ }^{96}$

\subsubsection{Internal staff and resources}

Like members of the German Bundestag, also members of the Dáil can rely on the knowledge and expertise provided by support staff in the administration as well as their own parliamentary assistants in their daily work and in their scrutiny of the Irish government in EU affairs. As said before, the increasingly complex issues with which parliamentarians are faced have as a consequence that both the legislative work and the effective scrutiny of the government in EU affairs by national parliaments depends on the work - and thus on the size and expertise - of the support staff, on which they can rely when dealing with such matters. Also in the Oireachtas a distinction is to be made between the parliamentary assistants that work for the individual TDs in the Dáil and the civil servants that work for the administration.

The exact amount of financial allowance for parliamentary assistants is not specified but according to Regulation 3(1) of the Oireachtas Ministerial and Parliamentary Offices Secretarial Facilities Regulations 2016 (Secretarial Facilities Regulation) ${ }^{97}$ each member of the Dáil is in general entitled to one full-time secretarial assistant (or a number of secretarial assistants working part-time as are equivalent to one assistant working full-time) as well as one parliamentary assistant working full-time (or a number of parliamentary assistants working part-time as are equivalent to one assistant working full-time). In addition, a TD may apply in writing for an additional full-time secretarial assistant under certain conditions and for specific reasons such as disability (Regulations 3(2) and 4 of the Secretarial Facilities Regulation).

The parliamentary administration of the Oireachtas in turn, which is called the Houses of the Oireachtas Service (hereinafter: the Service), is composed of 440 full-time general, professional and technical civil servants. ${ }^{98}$ Different than in Germany, no distinction is made between the upper and the lower chamber in this regard; instead the Service constitutes a joint administration for both Houses of the Oireachtas. This means that, for the

95 Ibid.

96 Barrett (2015), supra note 4, p. 292.

97 Oireachtas (Ministerial and Parliamentary Offices) (Secretarial Facilities) Regulations 2016, S.I. 2016/599, available at: <www.oireachtas.ie/documents/commission/si599-2016.pdf> (last retrieved on 14 February 2018).

98 Oireachtas website, The Houses of the Oirachtas Service, available at: <www.oireachtas.ie/parliament/about/parliamentaryadministration/> (last retrieved on 14 February 2018). 
overall 218 members of both Houses together (158 TDs and 60 Senators), there is a ratio of two civil servants per member of parliament. In terms of the organization of the Service, it is divided into three main departments: Parliamentary Services division and ClerkAssistant of the Dáil, Parliamentary Budget Office, and the Corporate and Members' Services division. ${ }^{99}$ The EU and external relations committees fall under the remit of the Parliamentary Services division. ${ }^{100}$ In general each committee in the Oirachtas has two staff members but this number may be increased dependent on the committee's workload. ${ }^{101}$ Thus, the Joint Committee on EU Affairs has four staff members: a clerk, a policy adviser, a junior clerk who carries out administrative work, and a clerical officer. Another three civil servants work for the EU Coordination Unit, while another five staff members advise the sectoral committes on EU affairs, in addition to the civil servants advising them on domestic issues. ${ }^{102}$ This means that for the overall 218 members of both Houses of the Oireachtas the ratio is approximately one EU expert staff per 18 members of parliament.

\subsubsection{The power to influence the government}

In addition to parliament's right to demand information, the question also poses itself as to what powers it has to use such information to influence the government's position in EU negotiations. The Irish parliament can try to change the government's position in such negotiations either through the issuing of legally binding mandates or through holding of plenary debates around European Council meetings in order to make it views known. The Irish parliament possesses this power only to a very limited extent with regard to certain measures, as will be further explained below.

\subsubsection{Scrutiny reserve and mandating procedures}

The scrutiny reserve is a mechanism which prevents ministers from agreeing to matters in the Council and European Council before the domestic parliamentary scrutiny process has been completed and which allows parliament to be involved in EU decision-making on an ex ante basis. ${ }^{103}$ The same rationale underlies the mandating procedure. The scrutiny reserve serves two purposes, namely giving parliament ample time to scrutinize the measure

99 Oireachtas website, Organisation Chart 2018, available at: <www.oireachtas.ie/parliament/media/ 8544498.pdf> (last retrieved on 14 February 2018).

100 Ibid.

101 Barrett (2015), supra note 4, pp. 296-297.

102 Ibid., p. 297.

103 P. Kiiver, The National Parliaments in the European Union - A Critical View on EU Constitution-Building, Kluwer Law International: The Hague, 2006, p. 56. 
in question as well as providing an escape option for governments at the EU level, if they are not able to agree upon a proposal. ${ }^{104}$

In Ireland, no general scrutiny reserve exists, despite several calls by Oireachtas subcommittees for its introduction in 2008 and 2010 respectively. ${ }^{105}$ Instead, a scrutiny reserve is provided only for certain options and measures. Thus, Articles 29.4.7 ${ }^{\circ}$ and 29.4.8 of the Irish Constitution require prior parliamentary approval for certain options and discretions as well as measures and acts concerning EU matters. Such matters include measures adopted under the enhanced cooperation procedure, acts relating to the Area of Freedom, Security and Justice (AFSJ) and acts authorizing the Council of the European Union to act other than by unanimity or those authorizing the adoption of the ordinary legislative procedure. ${ }^{106}$ In such cases, the government's discretion is limited by parliament, ${ }^{107}$ to whom the government must answer in relation to the negotiations at EU level. ${ }^{108}$ The Irish government or its ministers may not formally agree to a decision falling under the scope of these provisions, until such times as parliamentary approval has been given. ${ }^{109}$

By way of contrast to the German Bundestag, the Irish Dáil Éireann has no formal right to mandate its government before a European Council or Council meeting by means of drafting a binding opinion and hence it cannot influence the (Prime) Minister's position ex ante. ${ }^{110}$ In fact, Ireland, together with Bulgaria, Malta and the United Kingdom, is one of the very few exceptions in this regard, as all other national parliaments in the EU have

104 K. Auel, O. Rozenberg, A. Thomas, “Lost in Transaction? Parliamentary Reserves in EU Bargains”, (2012) OPAL Online Paper Series No. 10/2012, p. 4.

105 Barrett (2015), supra note 4, footnote 9; Joint Committee on European Union Affairs, supra note 55, p. 17.

106 Article $29.4 .7^{\circ}$ of the Irish Constitution states: "The State may exercise the options or discretions-

i. to which Article 20 of the Treaty on European Union relating to enhanced cooperation applies,

ii. under Protocol No. 19 on the Schengen acquis integrated into the framework of the European Union annexed to that treaty and to the Treaty on the Functioning of the European Union (formerly known as the Treaty establishing the European Community), and

iii. under Protocol No. 21 on the position of the United Kingdom and Ireland in respect of the area of freedom, security and justice, so annexed, including the option that the said Protocol No. 21 shall, in whole or in part, cease to apply to the State, but any such exercise shall be subject to the prior approval of both Houses of the Oireachtas.'

Article $29.4 .8^{\circ}$ states that: 'The State may agree to the decisions, regulations or other acts-

i. under the Treaty on European Union and the Treaty on the Functioning of the European Union authorising the Council of the European Union to act other than by unanimity,

ii. under those treaties authorising the adoption of the ordinary legislative procedure, and

iii. under subparagraph (d) of Article 82.2, the third subparagraph of Article 83.1 and paragraphs 1 and 4 of Article 86 of the Treaty on the Functioning of the European Union, relating to the area of freedom, security and justice,

but the agreement to any such decision, regulation or act shall be subject to the prior approval of both Houses of the Oireachtas."

107 O'Hegarty, supra note 21, p. 277.

108 Ibid., p. 276.

109 Ibid., p. 278 (citing a transcript of the meeting of the Joint Committee on European Affairs on 27 March 2002).

110 European Parliament, supra note 34, p. 48; Barrett (2015), supra note 4, p. 292. 
the possibility to adopt a resolution prior to European Council meetings. ${ }^{111}$ Instead, the focus of the Irish parliament lies in regular debates of statements of the Prime Minister on the European Council meetings. Nevertheless, ministers might feel honour-bound to consider parliamentary opinion when they are negotiating at EU level, ${ }^{112}$ despite the lack of any positive legal obligation in this regard. ${ }^{113}$ After all, Section 2(2) of the Scrutiny Act 2002 requires ministers to have regard to any recommendations made by parliament or one of its committees, if there is sufficient time to do so.

Even when the Dáil wishes to impose a certain position on the government with regards to EU negotiations, it has no formal power to do so, which leaves it considerably weaker in this regard when compared to the German Bundestag. The question remains, however, whether the introduction of a formal mandating system could actually improve the powers of the Irish Dáil in practice, i.e., whether it could be effectively used within the Irish parliamentary context. As was already discussed in Section 4.3.2, the so-called 'dilemma of parliamentary influence ${ }^{, 114}$ was mentioned, according to which the fact that the government is supported by the majority of parliament will also lead to it being unlikely that the said majority will oppose the government. Instead, supporting the government's policies will be an important task, which also excludes the issuing of legally binding opinions. ${ }^{115}$ This is all the more true with regards to the Irish parliament and the strong party whip system that is contained therein. ${ }^{116}$ Thus, political parties in Ireland are in general "very cohesive and disciplined and in most respects are increasingly centralized under the direction of the party leaderships." 117

This is also the case with regard to the composition of the committees, where most of the government scrutiny takes place. Typically, the committees are chaired by a parliamentarian from one of the government parties. ${ }^{118}$ The only exception is the Public Service Oversight and Petitions Committee, which is bi-partisan in structure and is chaired by a member of the opposition. ${ }^{119}$ In the other committees it is usually the government parties that hold a majority of seats and that furthermore appoint a so-called convenor, who

111 European Parliament, supra note 34, p. 48.

112 Laffan, O’Mahony, supra note 1, p. 96.

113 Barrett (2015), supra note 4, p. 292.

114 Auel, supra note 33, p. 491.

115 Ibid., citing W. Patzelt, "What can an Individual MP do in German Parliamentary Politics?", in L. Longley, R. Hazan (eds.), The Uneasy Relationship between Parliamentary Members and Leaders, Frank Cass Publishers: New York, USA, 2000, pp. 23-24.

116 O'Hegarty, supra note 21, p. 274.

117 Mitchell, supra note 12, p. 422.

118 M. Gallagher, “The Oireachtas: President and Parliament”, in J. Coakley, M. Gallagher (eds.), Politics in the Republic of Ireland, PSAI Press: United Kingdom, 2010, p. 220.

119 Statement of Common Purpose, supra note 7. 
ensures party discipline within the committee. ${ }^{120}$ Because the number of TDs in the Dáil is so small - the Dáil has 158 seats - the share of TDs that also become a member of government is relatively high. As a consequence, TDs that have the policy knowledge and capacity to chair a committee also have a high chance of becoming a minister at a later stage in their career, which in turn means that they would not be interested in having a strong committee system with a strict scrutiny function over government affairs, in the case that they would become part of the government at some point in the future. ${ }^{121}$

In addition, the committees generally do not have much research support available to them. Spending more time on scrutinizing the government in the committee and thus on committee work would lead to less time for the TDs to work on their constituency issues. ${ }^{122}$ The Irish electoral system of proportional representation by single transferable vote, in which voters vote directly for individual candidates in multimember constituencies, leads to the establishment of a strong tie between the politicians and their constituencies. They are generally more concerned with local issues and less inclined to deal with European affairs, ${ }^{123}$ which also decreases their proclivity to impose a certain position on the government with regards to the latter.

Apart from the difficulties arising out of the political context in Ireland, the issue remains, as has already been discussed, that the effectiveness of a mandating system is generally difficult to determine, as parliament may also have an interest in leaving its instructions as open as possible so as to not have a strict mandate backfire on them. This is arguably even more the case with regards to smaller Member States, who know that they do not have the power to determine the EU's agenda. Thus, instead of trying to push their own agenda, they will more likely try to mitigate the more unfavourable aspects of any proposal. ${ }^{124}$ A legally binding mandate would render such an attempt much more difficult; instead parliament and government are more likely to work together to promulgate their mutual interests.

\subsubsection{Obligation of the government to obtain prior parliamentary consent in matters concerning the ESM and EFSF}

With regards to the granting of financial assistance within the framework of the EFSF/ESM, the Irish parliament has the right to be informed in relation thereto. Decisions relating to

120 M. Maccarthaig, Accountability in Irish Parliamentary Politics, Institute of Public Administration: Ireland, 2005, p. 140.

121 Gallagher, supra note 118, p. 221.

122 Ibid.

123 European Parliament, supra note 63, p. 38.

124 Meenan, supra note 50, p. 315. 
the tranches of financial assistance are exclusively taken by the Minister of Finance, but a semi-annual report on all EFSF activities must be submitted to parliament. ${ }^{125}$

\subsubsection{Plenary debates}

Another means to exert influence on the Irish government in European Council meetings is to hold plenary debates around such meetings. The idea is that an ex ante plenary debate on the subject matter in question may have an influence on the government's positions with regards thereto and, even if it does not, at the very least it will make known the opinion of the parliamentary minority. Ex post it can serve to criticize the government's actions.

In Ireland, no statutory obligation exists for the government to appear in front of parliament before European Council meetings or Eurozone summits. Instead, this is done based on custom and practice, and it has existed since the election of the current government in 2011. ${ }^{126}$ As part of his election promises, the Prime Minister committed to briefing parliament two or three days before attending European Council meetings. ${ }^{127}$ What this briefing entails, however, is for the Prime Minister himself to decide. Generally speaking, a statement is prepared explaining the agenda of the forthcoming European Council meeting and it outlines the general position of the government. ${ }^{128}$ Such outlines are usually formulated rather broadly. ${ }^{129}$ The statement of the Prime Minister is heard without interruption, ${ }^{130}$ and afterwards no questions may be put to him concerning his statement. The leaders of the opposition parties are only permitted to make a statement of their own after the briefing has ended. ${ }^{131}$ This is then followed by some concluding remarks from the Prime Minister or, as a replacement, the Minister of Foreign Affairs. ${ }^{132}$ Thus, while the Prime Minister must appear before the plenary prior to European Council meetings, there is no obligation for him to directly respond to questions that are put to him.

The plenary debates after a European Council meeting, in contrast, are usually much longer. ${ }^{133}$ First, the Prime Minister gives his statement, which is given to the opposition, in writing and in advance, in order to facilitate the debate. ${ }^{134}$ Such a statement is normally more extensive than an ex ante statement and it typically includes a summary of the

125 N. Heinen, A. Theiss, "EFSF - Where Do National Parliaments Have a Say in the EMU”, (2011) Deutsche Bank Research.

126 Barrett (2015), supra note 4, p. 294.

127 Ibid., p. 294; European Parliament, supra note 63, p. 36.

128 European Parliament, supra note 63, p. 36.

129 Barrett (2015), supra note 4, p. 301.

130 Ibid.; European Parliament, supra note 63, p. 36.

131 Ibid.

132 European Parliament, supra note 63, p. 36.

133 Ibid.

134 Barrett (2015), supra note 4, p. 301. 
meeting's outcome. Its purpose is to paint the government in the best light possible. ${ }^{135}$ The statement by the Prime Minister is followed by statements of the opposition leaders or, in their absence, of the spokesperson for EU affairs of the relevant committees. Such statements in turn serve the purpose of trying to "deny or denigrate any claimed achievements of the government in the European Council under discussion." 136

Following the statements by the opposition leaders, there is a twenty-minute question time, during which questions can be asked to the Minister of State for European Affairs not, however, to the Prime Minister, who is not obliged to be in the chamber at that point. ${ }^{137}$ While question time is open to all members of the Dáil, it is usually only four or five members that tend to ask questions and most of the time those are the different European affairs spokespersons of the committees. ${ }^{138}$ Apparently it is rarely the case that more than ten members of parliaments are involved during the entire ex post debate. ${ }^{139}$

While it is theoretically possible for the government to not hold a debate on a European Council meeting, it is very likely that the opposition would try to seek information through parliamentary questions in the plenary sessions instead. ${ }^{140}$ As for Euro summits, they are controlled together with the European Council meetings by the plenary session of Dáil, to the extent that they are politically salient. ${ }^{141}$ In recent years, the main concerns in this regard were economic issues and the question of how to resolve Ireland's economic problems, and these have been the focus of Irish parliamentary debates before and after European Council meetings. ${ }^{142}$

Based on the Westminster model of parliament, the oversight of European Council meetings is thus mainly based on plenary sessions both ex ante and ex post since $2011 ;{ }^{143}$ expert committees play less of a role than in, for example, Germany. Therefore, Ireland was classified as a public forum model by Wessels et al. in their study for the European Parliament. ${ }^{144}$ In fact, together with the Netherlands and France, Ireland is one of the EU Member States with one of the highest number of ex ante plenary debates, ${ }^{145}$ as seven of such debates were held between March 2011 and March 2012. ${ }^{146}$ The same number of plenary debates, but ex post, was held after European Council meetings during the same

135 Ibid.

136 European Parliament, supra note 63, p. 36.

137 Barrett (2015), supra note 4, p. 301.

138 Ibid.; European Parliament, supra note 63, p. 36.

139 Ibid.

140 Ibid.

141 Ibid.

142 Ibid., pp. 301-302.

143 European Parliament, supra note 34, p. 37.

144 Ibid., p. 42.

145 Ibid., p. 38.

146 Ibid., p. 39. 
period, ${ }^{147}$ and together with Denmark it is the only parliament to hold such ex post debates on a regular basis. ${ }^{148}$

And yet, these plenary sessions seem to be poorly attended by both the press and by TDs. ${ }^{149}$ Barrett explains this by arguing that before the meeting, there is no interest in what the Prime Minister has to say because much can change during the negotiations at EU level in any case, while after the meeting, the plenary debates are often scheduled so late that the attention thereon has sunk as the results of the meeting have already been made known. ${ }^{150}$ Another reason for the low degree of interest may also be the Irish political system itself, which, as explained above, leads to parliamentarians being more concerned with local issues and less so on European matters. The latter is simply left to a small number of TDs, which are more involved in the EU plenary debates and the Joint Committee meetings. ${ }^{151}$

Thus, while the Prime Minister voluntarily appears before the Dáil before and after each European Council meeting, the scrutiny exercised by parliament is actually rather limited. This can, on the one hand, be explained by the traditionally low interest of the TDs and their irregular attendance. Normally, it is only those who are already specialized in EU affairs, i.e., opposition party leaders, spokespersons on EU affairs and Eurosceptic TDs, that are involved in the debates (besides the Prime Minister and the Minister of State for European Affairs). ${ }^{152}$ But on the other hand, even if the members of the Dáil wished to be more involved, they neither have the formal right to force the Prime Minister to reveal information he does not want to reveal, nor can they compel him to adopt a specific stance during the EU negotiations.

\subsubsection{The right to sanction the government}

Similar to the German Bundestag, the power of the Oireachtas in general and the Dáil Eireann in particular to sanction the government is limited. The most draconic sanction remains the dismissal of the government by parliament. Article 28.10 of the Irish Constitution requires the Prime Minister to resign from office if he loses the support of the majority in the Dáil, unless the President dissolves parliament on his advice and he secures the support of the majority of the newly elected Dáil - an option that is not available to the German Chancellor. Like the Bundestag, the Dáil can dismiss the government only as a whole (Article $28.11 .1^{\circ}$ of the Irish Constitution); no individual ministerial accountability

147 Ibid.

148 Ibid., p. 40.

149 European Parliament, supra note 63, p. 37.

150 Ibid.

151 Ibid.

152 Barrett (2015), supra note 4, p. 302. 
exists towards parliament. Thus, Article $28.4 .2^{\circ}$ of the Irish Constitution states that the government "shall meet and act as a collective authority, and shall be collectively responsible for the Departments of State administered by the members of the Government." If the Dáil disagrees with the actions of an individual minister, it has no means of dismissing the minister. The right to decide thereupon lies with the Taoiseach (Articles 28.9.2 ${ }^{\circ}$ and $3^{\circ}$ of the Irish Constitution), who may also request members of his cabinet to resign if he deems this to be desirable. Should the member concerned not follow this request, the Prime Minister can ask the President to nevertheless terminate his appointment (Article 28.9.4 ${ }^{\circ}$ of the Irish Constitution). The implications are the same as they are in Germany: the Dáil can merely threaten the Taoiseach to dismiss the government as a whole should he not remove his minister from office, but the effectiveness of such a threat and whether parliament would actually follow up on such a threat remains a moot point.

Another possibility of sanctioning the government is by means of parliament's budgetary rights. According to Article $28.44^{\circ}$ of the Irish Constitution, the government "shall prepare Estimates of the Receipts and Estimates of the Expenditure of the State for each financial year, and shall present them to Dáil Éireann for consideration.”

\subsection{ConCluding AND COMPARATIVE REMARKS}

As a conclusion, it can be said that the powers of the Irish parliament to control its government with regard to EU affairs is considerably weaker than that of the German parliament, despite the fact that new mechanisms have been introduced in recent years. While the European Council meetings are scrutinized in the plenary sessions of the Dáil, Council meetings are controlled at committee level. However, at both the plenary and the committee level, the interest and engagement of members of parliament seems to be very limited; this can be attributed to the Irish election systems on the one hand, which mainly rewards constituency work, but also to the absence of any possibility for the members of parliament to actually influence the (Prime) ministers' actions at EU level on the other. Thus, no general scrutiny reserve exists in Ireland. Neither does the Irish parliament have the power to issue a binding mandate on the executive for decisions taken at EU level.

Furthermore, except for the Minister for European Affairs who appears before the Joint Committee on European Affairs before the General Affairs Council meetings, ministers do not tend to regularly attend committee sessions. This can be explained by both motivational and time reasons on behalf of both parliament and government. Even at plenary level, where the Taoiseach has to brief the Dáil on European Council meetings, no possibility exists for members of parliament to directly pose questions to him. And this appearance by the Taoiseach is only required by practice based on the government's election promises that were made in 2011; it is not in fact laid down as a written legal obligation. 
As a consequence, while the Taoiseach does explain the government's actions in the European Council, he does not have to justify himself before parliament, as he does not have to reply to follow-up questions. Overall, there exists a lack of systematic control by the Irish parliament over its government when it comes to European affairs. ${ }^{153}$ This seems to be the result of a lack of interest from both parliament and the government to engage in a meaningful and effective dialogue on EU affairs.

In contrast, the parliamentary control over European Union affairs by the German Bundestag is not only more explicitly enshrined in the German Basic Law and accompanying secondary law, but it also has been substantively strengthened by the jurisprudence of the German Bundesverfassungsgericht, following a series of judgments in this ambit. For example, the parliamentary right to information is not only very broadly interpreted in Germany but it also protected by the eternity clause that is contained in Article 79(3) of the German Basic Law according to the Bundesverfassungsgericht, which shows the importance that the latter accords to it. The scrutiny reserve is laid down in the German Constitution itself (Article 23(2) of the GG) and, unlike in Ireland where it only exists for very specific measures, it is applicable to all decisions that are taken at EU level. And with regard to parliamentary mandates, while the government does not suffer any consequences for deviating from parliamentary statements of opinion, it does have the obligation to justify any deviations.

Differences can also be discerned in the committee structures of the two respective countries. While in Germany it is the European Affairs Committee that has the principal task of scrutinizing documents pertaining to EU affairs, in Ireland this power is reserved for the specialized sectoral committees. The Joint Committee on European Union Affairs only deals with the strategic direction of the EU and cross-sectoral EU matters. The problem is, however, that the sectoral committees neither spend much time on the scrutiny of EU matters, nor do they put much effort into coordinating said scrutiny between each other, which leads to a situation whereby the parliament as a whole does not have any ownership over EU scrutiny. In the German Bundestag, on the other hand, it is the EAC that, in consultation with the other specialized committees, takes the decision on which documents should be referred to the specialized committees for further discussion. When no specialized committee can be discerned, the EAC itself will deal with document in question. Moreover, under Article 45 of the GG, the EAC may also exercise the rights pursuant to Article 23 of the GG against the German government upon authorization by and on behalf of the Bundestag plenary. The Irish Joint Committee does not have this power, which in Germany is existent only for the EAC. The EAC is also the only committee in the German Bundestag that can ask for an amendment to the recommendation for a resolution submitted by another specialized committee. So overall, the German EAC has

153 Barrett (2015), supra note 4, p. 306. 
more wide-ranging scrutiny and coordinating powers vis-à-vis EU affairs, when compared to its Irish counterpart.

The latter is also a consequence of the lack of interest of the sectoral committees in the Irish Oireachtas. Since the latter are not very engaged and are often delayed in their scrutiny, there is little room for the Joint Committee to participate or coordinate. This disinterest can be attributed to the lack of salience of EU issues in Ireland, where TDs are rewarded and re-elected on the basis of their constituency work. Often the busy timetables in the committees do not permit lengthy discussions on EU affairs, especially if national and local issues are deemed to be of more importance and are hence prioritized. As such, only a small number of TDs in the Oireachtas who are specialized in EU affairs have an interest in exercising stringent scrutiny over the government's actions in Brussels. This is less so the case in Germany, where election results are not as dependent on constituency issues, simply because less than half of the MPs are elected from within constituencies.

Also with regard to the number and size of the parliamentary administrations that support the daily work of parliamentarians differences exist. While the Bundestagsverwaltung employs around 3000 civil servants, the joint administration of both Houses of the Oireachtas is composed of around 440 civil servants. This means that, depending on the exact number of the Bundestag, there are around four to four and a half civil servants per MdB. In contrast, the ratio is only two civil servants per member of parliament in the Oireachtas. The German Bundestag can also dispose of a greater range of administrative departments when it comes to EU affairs - which in turn, mean more specialized knowledge - than its Irish counterpart. Not only does the Bundestagsverwaltung comprise a department dealing exclusively with fundamental EU and EMU issues, but the staff to MdB ratio in EU affairs is also approximately one EU expert staff member per ten MdBs, whereas in the Irish Oireachtas the same ratio is approximately one EU expert staff per 18 TDs. It is possible that this difference can also be explained by the fact that much of the work done in the Irish parliament is constituency work, which perhaps reduces the necessity of having as an extensive number of civil servants for EU matters as, for example, Germany, where EU issues are much more salient.

Similarities between the two parliaments can be found in the parliamentary form of government in both Ireland and Germany, in which the government is supported by the majority of the parliament. Because it is the majority parties who form the government, they are generally more reluctant to publicly criticize and oppose governmental actions at EU level. This role falls to the opposition parties, who play a crucial role in the scrutiny process. As they do not belong to the governing parties, however, it is often the case that they do not receive same information as the majority parties. Rules regarding the right to information are therefore especially important for opposition parties in order to facilitate the closing of the information gap between them and the government. While the right to information in Germany has been very broadly interpreted and strengthened by the Federal 
Constitutional Court - sometimes enforced even against the parliament itself - the opposition in Ireland seems to be less interested in closing the information gaps that is necessary to properly scrutinize the government. Not only are the rules regarding the right to information itself weaker in Ireland, but the opposition TDs are often more concerned with embarrassing the ministers than with eliciting information from them during questioning.

These differences, as illustrated by the variations between the parliaments in Ireland and Germany, exist to a much larger extent between all 28 Member States of the European Union, where rules and procedures with regard to the scrutiny of EU matters, but also political culture, are even more diverse than between the two Member States which have been discussed in this book. While this in itself might not be a new revelation, it does pose some new issues when it is considered in the light of the developments in the EMU during the Euro crisis, which had the effect of intensifying such differences between the various national parliaments. One very straightforward example, as to why the differences in rules and practices exist between the national parliaments in the EU when it comes to controlling their governments, is that it can have detrimental consequences on representative democracy, as was described in the introductory chapter of this book. When it comes to decisions taken by the European Stability Mechanism, the Irish Dáil only has the right to be informed; all decision-taking powers lie with the Minister of Finance in Ireland. In Germany, on the other hand, all decisions taken in the ESM by the German representative must, following a ruling by the Bundesverfassungsgericht on this matter, be approved by the Bundestag before the former can act. These difference in rules, in conjunction with the fact that Ireland had requested financial assistance under the then-EFSF, led to a situation in which the German parliament (or rather a committee thereof) received the 2012 Irish draft budget before the Irish parliament did - presumably in order for the German Bundestag to give its approval for financial assistance as is required under German law.

The strong position of the Bundestag vis-à-vis the German government in this matter had an incidental effect on the parliamentary rights of another Member State's parliament. Budgetary rights are the prerogative of any (national) parliament, meaning that the fact that another Member State's parliament had access to the draft budget before the country's own parliament was considered by many to be an encroachment upon Irish sovereignty and democracy. The next chapter will further depict the impact that the Euro crisis and the measures adopted thereto had on the differences between the national parliaments and it will argue that such differences have led to an exacerbation of the asymmetric power situation between parliaments of the various Member States, which in turn has implications for representative democracy in the European Union as a whole. 


\section{THE ASYMMETRIC IMPACT OF THE CRISIS ON NATIONAL PARLIAMENTS}

\subsection{INTRODUCTION}

The last two chapters of this book dealt with the (formal) powers of the German Bundestag and the Irish Dáil Éireann to participate in EU affairs under their respective constitutional law and demonstrated the differences that exist in this regard between them. These divergent degrees of powers between the German and the Irish parliament can be seen as an example of the general situation of power asymmetries between national parliaments that is existent in the EU. While the degree to which such power asymmetries exist also depends on the ability and willingness of parliaments to put these powers into use in practice, on a formal level these asymmetries can primarily be attributed to the diverging constitutional frameworks under which each national parliament operates.

While it can be argued that a differentiation in national parliamentary powers in EU affairs is inherent in the nature of the EU's constitutional design, which accepts and relies on the different domestic legal systems of its Member States, such a differentiation can, in light of the developments during the European sovereign debt crisis, however, no longer be accorded to domestic constitutional law alone. Much of the research done on national parliaments in the EU during the last decade has been focused on how national parliaments have (re-)emerged from their role as the "losers of integration" ${ }^{\text {'1 }}$ and adapted to the changes resulting from the European integration process. However, much of the participation rights that national parliaments have over time acquired in EU affairs under their domestic law was tailored to the ordinary legislative procedure in EU law, as opposed to the more intergovernmental nature of decision-making during the European sovereign debt crisis. Also due to the urgent nature of the latter, national parliaments increasingly struggled to participate in decision-making therein. This chapter will examine in more detail the measures that were adopted in the European Union as a response to the Eurozone crisis, with a focus on how these measures impacted the powers of national parliaments in the EU. It will show that such impact was, in fact, very different for each national parliament

1 See, for example: P. Kiiver, National Parliaments in the European Union: A Critical View on EU ConstitutionBuilding, Kluwer Law International: The Hague, The Netherlands, 2006; J. O’Brennan, “Introduction: Deparliamentarization through European Integration?”, in: J. O’Brennan, T. Raunio (eds.), National Parliaments Within the Enlarged European Union: From 'Victims' of Integration to Competitive Actors?, Routledge: United Kingdom, 2007, pp. 1-25; A. Maurer, W. Wessels (eds.), National Parliaments on their Ways to Europe: Losers or Latecomers?, Nomos Verlagsgesellschaft: Baden-Baden, Germany, 2001. 
in the EU, which turn lead to a further exacerbation of power asymmetries between national parliaments.

The purpose of this chapter is to analyze how and to what extent national parliaments in the European Union have been affected by the Eurozone crisis and the measures adopted as a response thereto. It will show that, while there has always been a differentiation in parliamentary control in the EU, this differentiation is increasingly driven by the European level as opposed to the national level. In order to do so, it will demonstrate that not all national parliaments were affected to the same extent and in the same way by the crisis and the responses that were adopted thereto. A distinction will be made (1) between Eurozone and non-Eurozone Member States, (2) between different groups of Member States within the Eurozone itself and (3) between signatory and non-signatory non-Eurozone parties to the Treaty on Stability, Coordination and Governance in the Economic and Monetary Union (TSCG). The chapter will conclude with an outlook on what this asymmetric impact of the crisis on national parliaments means for the concept of representative democracy in the EU.

\subsection{NATional PARLiaments in times OF CRISIS}

After having been categorized as the 'losers of European integration' for decades, ${ }^{2}$ national parliaments managed to claim back some of their participation rights in European Union affairs, some of which are even explicitly recognized in the Treaty of Lisbon itself. This gradual strengthening of national parliamentary powers at the EU level is, however, in the danger of being reversed. The reasons for this fear or claim are manifold. An important reason is the constraints that have been placed on the budgetary powers of Member States and also their national parliaments, which have in turn been imposed by the new economic governance structures that were established as a response to the crisis. This new economic governance includes the European Semester (ES), the Six-Pack, the Two-Pack, the Treaty on Stability, Coordination and Governance in the Economic and Monetary Union as well as the European Financial Stability Facility (EFSF) and European Stability Mechanism (ESM) Treaties. Laying down stricter rules with regard to the Stability and Growth Pact (SGP) of 1997 and requiring Member States to adopt sustainable budgets, not only do they severely limit the discretion of national parliaments when it comes to decisions on their national budgets, but they have also established a supervisory role for the EU institutions. For example, under the European Semester, the European Commission may issue binding recommendations to the Member States on their national reform or stability programmes; for Euro Member States, the Commission also has the power to issue comments on the

2 See, for example: Kiiver, supra note 1; O’Brennan, supra note 1. 
national draft budgets. This curtailment is even more severe for national parliaments of Member States that are subject to a financial assistance programme (see Section 6.2.1.4.2). Thus, Member States such as Greece, Portugal and Spain are bound by so-called Memoranda of Understanding (MoU), which impose strict conditionality in return for financial assistance under the ESM or EFSF funds. The so-called Troika, consisting of the European Central Bank (ECB) together with the European Commission and the International Monetary Fund (IMF), monitors the implementation of these MoU by the Member State in question, leaving hardly any room for national parliaments to participate therein. National parliaments have almost no means of controlling the Troika, thereby leaving a discrepancy between national politics and national democratic representation, which in turn has consequences for the legitimacy of the decisions, especially when considered from the perspective of representative democracy. ${ }^{3}$ Overall, it can be said that the budgetary processes in the Member States have become "Euro-national" 4 as opposed to the merely national procedure that it was before the crisis. ${ }^{5}$

Secondly, the crisis - due to its urgent nature - has also led to a strengthening of European executive powers, meaning the European Council, the Euro summit (consisting of the Heads of State or Government of the Euro Member States) and the Eurogroup (consisting of the finance ministers of the Eurozone). The (re-) emergence into power of these (partly informal) intergovernmental institutions has had an impact on the powers of national parliaments in the sense that it became increasingly difficult for the latter to remain informed about the negotiations at EU level, which were mostly held behind closed doors; more often than not, national parliaments would be confronted with faits accomplits by their governments afterwards, rather than being involved before or during the discussions. This consequently led to the marginalization of the European Parliament, as well as the exclusion of the national parliaments from the negotiation process; their role was reduced to that of external veto-players, ${ }^{6}$ meaning that they could have a say in whether a decision is being taken or not (i.e., a veto power), but were not able to influence the content of the decision itself. It is important to note, however, that this strengthening of the European executive at EU level did not mean the strengthening of all national governments to the same extent. This was quite the opposite for some. For example, the national governments Member States receiving financial assistance saw their powers considerably weakened rather than strengthened. ${ }^{7}$

3 C. Fasone, “Taking Budgetary Powers Away From National Parliaments? On Parliamentary Prerogatives in the Eurozone Crisis", (2015) EUI Working Papers LAW 2015/37, p. 4.

$4 \quad$ Ibid., p. 10.

5 Ibid.

6 A. Benz, “An Asymmetric Two-Level Game: Parliaments in the Euro Crisis”, in: B. Crum, J.E. Fossum (eds.), Practices of Inter-Parliamentary Coordination in International Politics - The European Union and Beyond, ECPR Press: United Kingdom, 2013, p. 139.

7 Fasone, supra note 3, p. 11. 
The third and last impact that the crisis - or rather the response thereto - had on the role of national parliaments in the EU stemmed from the fact that some of the crisis response measures, such as the TSCG or the EFSF and ESM Treaties, were adopted as intergovernmental treaties outside of the EU law framework. As a consequence, many governments did not regard these treaties as a matter of EU law, to which all rights and obligations, such as parliament's right to information (Protocol $\mathrm{No}^{\circ} 1$ ) applied, but rather they were seen as a matter of foreign policy, which typically means that national parliaments are less involved (for an exception, see Chapter 4 on Germany and the rulings of the Bundesverfassungsgericht $).{ }^{8}$ In matters of foreign policy, parliaments often only have the right to ratify the treaty, but they cannot actively intervene or influence the content of the treaty during the negotiation phase. ${ }^{9}$ Thus, national parliaments faced much more difficulties in participating and controlling the actions of their governments during the negotiation of intergovernmental agreements than they had with regard to measures falling under European Union law, where they could have recourse to their existing participation rights in EU affairs, ${ }^{10}$ although again this was not the case for all national parliaments.

The German Bundestag, for example, saw its participation rights immensely strengthened as a result of the jurisprudence of the German Federal Constitutional Court especially in matters that were not considered to fall within the scope of EU law. Overall, national parliamentary rights were affected differently according to the nature of the crisis response measures that were adopted. Where there was no court effectively counter steering such development, national parliaments (as well as the European Parliament) were largely sidestepped in the adoption of such measures - with the collapse of the Eurozone serving as a justification ${ }^{11}$ - and they hardly had any influence during the negotiation process. ${ }^{12}$ This was different for regular Union law measures, where national parliaments could have recourse to their regular participation rights, as they existed before the crisis.

\subsubsection{The asymmetric impact of the crisis}

The consequences of the crisis for national parliamentary prerogatives were not, as was already implied above, the same for all Member States and all national parliaments in the European Union. ${ }^{13}$ Instead, the way and the degree to which national parliamentary powers were affected by the crisis depended on different factors, such as whether a Member

8 O. Höing, "Differentiation of Parliamentary Powers - The German Constitutional Court and the German Bundestag Within the Financial Crisis", (2012) OPAL Online Paper Series | 9/12, p. 6.

9 O'Brennan, , supra note 1, p. 3.

10 Fasone, supra note 3, p. 15.

11 Ibid., p. 20.

12 Ibid.

13 Höing, supra note 8, p. 4. 
State was a member of the Eurozone; whether it was a contracting party to the TSCG; whether it received financial assistance or provided such assistance and, last but not least, it depended on the institutional strength of the individual national parliaments $v i s-\grave{a}$-vis their national government in EU affairs. It is thus necessary to differentiate between the different groups of Member States and parliaments when assessing the impact of the crisis on the latter.

The following part will address the asymmetric impact of the crisis in the following manner: first, it will look at the different consequences for national parliaments resulting from the traditional differentiation ${ }^{14}$ between Eurozone Member States and those Member States that have not (yet) adopted the common currency. While not all of the instruments that were adopted as a response to the crisis are limited to Eurozone Member States (see, for example, the European Semester), there are a still wide number of measures that apply exclusively to Eurozone Member States (see for example, the Two-Pack). This also means that national parliaments from Eurozone Member States are subject to more obligations and limitations than non-Eurozone parliaments, not least with regard to their budgetary rights. $^{15}$

The second differentiation that should be made is within the group of Eurozone Member States themselves. ${ }^{16}$ As was already explained above, the domestic constitutional setting of each Member State determines the power of its national parliament in EU affairs and $v i s$ - $\grave{a}$-vis its national government. This has proven to be the case even more so during the crisis. The gap between those national parliaments that are 'stronger' from an institutional perspective - understood as those parliaments, which under domestic law have wide-ranging powers vis-à-vis their national governments in EU affairs - and those national parliaments that are institutionally regarded as 'weaker' - understood as national parliaments with only limited powers vis-à-vis their national governments in EU affairs - has not become smaller, but rather this divergence has become more pronounced during the crisis. Generally, and as will be shown in this chapter, it can be said that those national parliaments that have been endowed with a stronger role in EU affairs under domestic law, even before the crisis, have gained more powers during this crisis, while weak national parliaments have become even weaker, or at least remained similarly strong or weak respectively.

However, it is not only the comparative institutional strengths of the respective national parliaments that lead to an asymmetric situation between them; it has been acknowledged that the economic strength of their respective Member States also plays a role in this regard. Because national parliaments and governments do not interact with each other in a vacuum,

14 C. Fasone, "Eurozone, Non-Eurozone and 'Troubled Asymmetries' Among National Parliaments in the EU: Why and to What Extent This is of Concern", (2014) 6 Perspectives on Federalism, p. 5.

15 Höing, supra note 8, p. 8.

16 Ibid. 
their relationship is in no small way also determined by the economic conditions of their Member State; this is especially the case where the economic situation of a Member State is considered dire enough to justify the bypassing of parliament for the sake of urgency, but it also relates to, for example, the emergency voting procedure under the ESM Treaty, where a difference is made according to the contribution size of the contracting parties (see Section 6.2.1.4.2). It is thus also necessary to make a differentiation - within the Eurozone - between national parliaments from economically stronger Member States and national parliaments from economically weaker Member States.

The third and last differentiation can be made between non-Eurozone parliaments according to whether their Member State is a contracting party to the TSCG or not. The TSCG severely affects the national parliaments' budgetary rights by requiring them to adhere to the balanced budget rules, but while most non-Eurozone Member States are signatories thereto, the Czech Republic, the United Kingdom and Croatia are not. Other Member States, while still a contracting party, have decided to opt out of certain parts of the TSCG. ${ }^{17}$ The degree to which each non-Eurozone Member State has decided to adhere to the TSCG, in turn determines the extent to which its parliament will have to adhere to European rules when exercising their budgetary rights at the national level.

In sum, what now exists in the European Union are highly fragmented groups of Member States to which very different sets of rights and obligations under the new economic governance framework apply, both within the Eurozone and outside of it. This also means that that the 28 (soon 27) national parliaments in the European Union are subject to very different rights and obligations and are limited to different extents when it comes to their national budgetary powers. The asymmetry of powers between the 28 national parliaments that already existed before, due to the differences in the domestic constitutional settings of the respective Member States, has now become even more pronounced as a result of the asymmetric impact of the crisis on the Member States and consequently on their national parliaments.

\subsubsection{Eurozone vs. non-Eurozone}

The division between Eurozone and non-Eurozone Member States is almost selfexplanatory. When the Economic and Monetary Union (EMU) was launched in 1993 following the entry into force of the Treaty of Maastricht, it was adopted with the intention of doing so in three stages. As is well known, the introduction of the single currency, the Euro, on 1 January 1999 was the beginning of the third stage of the EMU which has been ongoing ever since. While all EU Member States take part in the Economic and Monetary Union as such, thereby obliging them to coordinate their economic policies, not all Member States are part of its third stage, i.e., the Eurozone. In order to join the single

17 Fasone, supra note 14, p. 4. 
currency, Member States have to fulfill certain criteria relating to price stability, soundness and sustainability of public finances, exchange-rate stability and long-term interest rates. ${ }^{18}$ Only those Member States that fulfill these convergence criteria (also known as the 'Maastricht criteria') may join the Eurozone; all others remain 'Member States with a derogation' (Article 139(1) TFEU), until they meet the criteria, in which case the derogation will be abrogated through a decision of the Council, on a proposal from the Commission and after consulting the European Parliament and discussing the matter in the European Council (Article 140(2) TFEU).

In principle, all EU Member States are expected to join the third stage of the EMU once they meet the convergence criteria, as the Treaty of Lisbon only formally sets out the possibility of a derogation if a Member State does not (yet) fulfill the necessary conditions for Eurozone membership ('pre-ins'). ${ }^{19}$ However, this does not apply to Denmark and the UK, which both have an opt-out from adopting the single currency. Compared to the derogations promulgated by the other Member States, which are based on economic grounds, the Danish and British opt-outs have been negotiated on political grounds, even though in practice the effect is the same..$^{20}$ Thus, Protocol $\mathrm{No}^{\circ} 16$ relating to Denmark and Protocol $\mathrm{No}^{\circ} 15$ relating to the United Kingdom stipulate an exemption for both states from participating in the third stage of the EMU. In reality, however, there is a third Member State - namely Sweden - that has been allowed to refrain from adopting the Euro through a biased mathematical calculation that regularly concludes that Sweden does not fulfill the required macro-economic criteria, ${ }^{21}$ after the common currency was rejected in a referendum in $2003 .^{22}$

While the status of those Member States that have not (yet) adopted the Euro as their currency differs - some are obliged to join the Eurozone in the future, others have an optout - for the purpose of this section, they will all be treated the same, namely as nonEurozone members. As of January 2015, 19 Member States have joined the Eurozone and nine Member States remain non-Eurozone states. The current members of the Eurozone are: Austria, Belgium, Cyprus, Estonia, Finland, France, Germany, Greece, Ireland, Italy, Latvia, Lithuania, Luxembourg, Malta, the Netherlands, Portugal, Slovakia, Slovenia and Spain, with Lithuania having joined as the latest Member State in January 2015.

Depending on whether a Member State has adopted the Euro or not, very different sets of crisis response measures apply to them. The ESM Treaty, for example, is an intergovernmental Treaty that has only been concluded by Member States of the Eurozone so

18 Article 140(1) TFEU.

19 S. Fabbrini, "After the Euro Crisis: A New Paradigm on the Integration of Europe", (2014) ARENA Working Paper 5, p. 7.

20 C.D. Ehlermann, "Increased Differentiation or Stronger Uniformity?", (1995) EUI Working Paper RSC No. 95/21, p. 13.

21 Fabbrini, supra note 19, p. 5.

22 Fasone, supra note 14, p. 7. 
as to set up a permanent emergency fund amongst them. Moreover, the Two-Pack ${ }^{23}$ and two regulations out of the six legislative acts of the Six-Pack are exclusively applicable to the Eurozone. ${ }^{24}$ The other four measures of the Six-Pack are applicable to all EU Member States, even though some exceptions are made within the individual acts: for example, the UK is not bound by Articles 5 to 7 of Directive 85/2011 on budgetary framework requirements, ${ }^{25}$ and while Regulation 1177/2011 on speeding up and clarifying the implementation of the Excessive Deficit Procedure ${ }^{26}$ is, in principle, applicable to all Member States, the sections on ECB surveillance are only applicable to the Euro area and the ERM II Member States. The TSCG, on the other hand, is also an intergovernmental Treaty, signed by all Eurozone Member States as well as non-Eurozone Member States, except for the UK, the Czech Republic and Croatia. The consequence of this jigsaw puzzle of post-crisis measures is that Eurozone Member States are now subject to much stricter rules and limitations than non-Eurozone Member States, even more so than before the crisis, which in turn places a bigger constraint on their national parliaments when it comes to taking budgetary or fiscal and economic policy decisions. ${ }^{27}$

Generally, it can be said that non-Eurozone parliaments enjoy more room of maneuver in this context. ${ }^{28}$ For one, their obligations under the European Semester are not the same as for Eurozone parliaments. The European Semester is the EU annual six-month cycle of economic and fiscal policy coordination and surveillance that was introduced in 2010, launched in 2011 and codified in the Six-Pack. It lays down the framework within which the European Commission and the Member States of the European Union discuss the

23 Regulation (EU) No. 473/2013 of the European Parliament and of the Council of 21 May 2013 on common provisions for monitoring and assessing draft budgetary plans and ensuring the correction of excessive deficit of the Member States in the euro area, [2013] OJ L140/11, and Regulation (EU) No. 472/2013 of the European Parliament and of the Council of 21 May 2013 on the strengthening of economic and budgetary surveillance of Member States in the euro area experiencing or threatened with serious difficulties with respect to their financial stability, [2013] OJ L140/1.

24 Regulation (EU) No. 1173/2011 of the European Parliament and of the Council of 16 November 2011 on the effective enforcement of budgetary surveillance in the euro area, [2011] OJ L306/1, and Regulation (EU) No. 1174/2011 of the European Parliament and of the Council of 16 November 2011 on enforcement measures to correct excessive macroeconomic imbalances in the euro area, [2011] OJ L306/8.

25 Council Directive 2011/85/EU of 8 November 2011 on requirements for budgetary frameworks of the Member States, [2011] OJ L306/41.

26 Council Regulation (EU) No. 1177/2011 of 8 November 2011 amending Regulation (EC) No. 1467/97 on speeding up and clarifying the implementation of the excessive deficit procedure, [2011] OJ L306/33.

27 The consequences for parliaments from Eurozone Member States are not all negative, however. Jancic, for example, stipulates that "the crisis and its procedural offspring, the European Semester, have provoked a proliferation and intensification of parliamentary activity in budgeting and EU affairs", using as positive examples "new rights of approval in the budgetary process, the emergence of new scrutiny practices and the improvement of the existing ones, government ousters and subsequent concessions to parliaments, a greater involvement of sectoral committees, a more rigorous scrutiny over the European Council, the creation of new interparliamentary bodies and the refinement of the political dialogue with the Commission." See D. Jancic, "National Parliaments and EU Fiscal Integration", (2016) 22 European Law Journal, p. 247.

Fasone, supra note 14, p. 7. 
fiscal and structural reforms that are necessary to achieve the EU's objectives, both under the Europe 2020 strategy and the Stability and Growth Pact. ${ }^{29}$ As per the European Semester, all Member States are required to submit their Stability or Convergence Progammes (SCPs) ${ }^{30}$ and National Reform Programmes (NRPs) before the end of April and before the start of their national budgetary procedures, on the basis of which the European Commission will issue so-called Country-Specific Recommendations (CSRs). All EU Member States then implement these CSRs during their national budgetary processes. The TwoPack, however, sets out further obligations exclusively for the Eurozone Member States. According to Regulation 473/2013, Eurozone Member States are now required to submit their draft budgetary plans (DBPs) to the European Commission and the Eurogroup before mid-October, so as to allow the Commission time to assess their compliance with the respective Stability Programmes and CSRs. The Commission then adopts an opinion on these draft budgetary plans and, where necessary, it may ask for a revised plan to be submitted. ${ }^{31}$ All Euro area Member States must adopt their final budget before 31 December of each year (Article 4(3) of Regulation 473/2013). Such a reinforced European Semester for the Euro area consequently means that the Eurozone parliaments are much more constrained in the exercise of their budgetary powers, especially when compared to their counterparts that operate outside of the Eurozone.

Not only are they faced with procedural limits insofar as they are bound by fixed timelines under the Two-Pack, but they also face substantive constraints because the Commission may now intervene in an area that was previously an exclusive power of national parliaments. Instead of being purely national, the budgetary processes of the Member States after the reform of the economic governance have become "Euro-national", 32 which in effect means the imposition of more EU requirements on Eurozone national parliaments when deciding on the national budget. National parliaments operating outside the Eurozone, on the other hand, while they are not completely free in exercising their powers, have nevertheless retained a higher degree of discretion in relation to their budgetary procedures. ${ }^{33}$

The information collected from the Member States within the framework of the European Semester, in particular the deficit and debt statistics, also plays a role in a decision

29 See for a discussion of the European Semester: P. Coenen, A.W. Heringa, H.T. Nguyen, S. Wolf, "Europees Semester", (2015) Montesquieu Institute Policy Paper Nr. 6.

30 Stability programmes are submitted by Euro area MS, while Convergence Programmes are submitted by non-Eurozone Member States.

31 Articles 6 and 7 of Regulation 473/2013.

32 Fasone, supra note 3, p. 10.

33 Fasone, supra note 14, p. 7. 
by the Council and the Commission to start an Excessive Deficit Procedure (EDP), ${ }^{34}$ which is laid down in Article 126 TFEU and reinforced by the Six-Pack. Similarly, it may also provide the basis for the initiation of the newly introduction Excessive Imbalance Procedure (EIP). In the beginning of each European Semester the Commission publishes the Alert Mechanism Report (AMR), in which it assesses the qualitative economic and financial situation in the Member States and identifies those, which it considers to be affected, or at the risk of being affected, by imbalances. ${ }^{35}$ For those Member States the Commission then, within the framework of the European Semester, carries out an in-depth review (Article 5 Regulation 1176/2011) and where such an in-depth review concludes that the Member State concerned is affected by excessive imbalances, an EIP may be opened by the Council on recommendation by the Commission against that Member State (Article 7 Regulation 1176/2011).

The systems of sanctions under these procedures are different for Eurozone Member States and non-Eurozone Member States. For example, Article 126(11) TFEU provides for the possibility of sanctions for all Member States, when they persistently fail to comply with Council recommendations concerning specific actions to correct an existing excessive deficit. Such sanctions may range from a mere requirement to publish additional information, to inviting the European Investment Bank to reconsider its lending policy towards the Member State concerned or requiring the latter to lodge a non-interest bearing deposit of an appropriate size with the Union, until such times as the excessive deficit has been corrected, to the imposition of a fine on the Member State concerned by the Council. Article 126(11) TFEU thus allows for the imposition of less stringent measures than the imposition of a fine, if there is a failure to comply with the Council recommendations. This is not the case anymore when it concerns a Eurozone Member State. Article 11 of Regulation 1177/2011 now requires, as a rule, the imposition of fines for Eurozone Member States ('participating Member States'). What is, moreover, interesting to note is that the United Kingdom is exempted from receiving sanctions. ${ }^{36}$ Article 4 of Protocol $\mathrm{No}^{\circ} 15$ provides that Articles 126(1), (9) and (11) TFEU - amongst others - are not applicable to the United Kingdom, thus precluding the Council and the Commission from imposing sanctions on the UK in whatever form when it comes to avoiding excessive deficits.

34 J.D. Savage, D. Howarth, "Enforcing the European Semester: The Politics of Asymmetric Information in the Excessive Deficit and Macroeconomic Imbalance Procedures", (2018) 25 Journal of European Public Policy, pp. 212-213.

35 Article 3 of Regulation (EU) No. 1176/2011 of the European Parliament and of the Council of 16 November 2011 on the prevention and correction of macroeconomic imbalances, [2011] OJ L 306/186. 
Regulation $1175 / 2011^{37}$ requires all Member States to attain a country-specific MediumTerm Objective (MTO), ${ }^{38}$ even though the UK is exempted from this obligation. ${ }^{39}$ The MTO is a reference value for individual Member States' medium-term budgetary positions, defined in structural terms and which is revised every three years. It provides a safety margin for the Member States towards the 3\% deficit ceiling and ensures the sustainability of the Member States' public finances (Article 2a of Regulation 1175/2011). For Member States whose currency is the Euro and for Member States participating in the ERM II, ${ }^{40}$ the regulation stipulates an MTO of between -1\% of GDP and in balance or surplus (Article 2a of Regulation 1175/2011). The Fiscal Compact reinforces this rule by imposing an even more stringent MTO limit on its contracting parties: Article 3(1) of the TSCG stipulates a lower structural deficit of $0,5 \%$ of GDP as opposed to $1 \%$. Member States that have not reached their MTO must be on an appropriate adjustment path towards it, with an annual improvement of 0,5\% of GDP being set as the benchmark (Article 5(1) of Regulation 1175/2011). Under the Six-Pack, even a significant deviation from this adjustment path towards the MTO $^{41}$ by a Member State may lead to recommendations by the Commission to address such a deviation, and for Eurozone Member States to impose sanctions, even when the 3\% rule has not yet been breached (Article 6 of Regulation 1175/2011). Member States that are contracting parties to the Fiscal Compact are furthermore required to have a correction mechanism in place, which is to be triggered automatically if a significant deviation from the adjustment path is observed (Article 3(1) of the TSCG).

Regulation 1173/2011 amends the system of sanctions applicable to Eurozone Member States with regards to both the preventive and corrective arms of the Stability and Growth Pact, i.e., the multilateral surveillance system and the EDP, by introducing reverse qualified

37 Regulation (EU) No. 1175/2011 of the European Parliament and of the Council of 16 November 2011 amending Council Regulation (EC) No. 1466/97 on the strengthening of the surveillance of budgetary positions and the surveillance and coordination of economic policies, [2011] OJ L306/12.

38 The original Stability and Growth Pact of 1997 stipulated a common MTO for all Member States. Since the 2005 reform, the MTO is now country-specific.

39 Fasone, supra note 14, p. 7.

40 Participation in the Exchange Rate Mechanism (ERM II) is part of the convergence criteria for joining the third stage of the EMU, i.e., the Euro. It ensures that the exchange rate fluctuations between the Euro and other EU currencies do not disrupt economic stability in the single market. Currently, it is only Denmark that participates in the ERM II.See: European Commission website, ERM II - The EU's Exchange Rate Mechanism, available at: <https://ec.europa.eu/info/business-economy-euro/euro-area/enlargement-euroarea/introducing-euro/adoption-fixed-euro-conversion-rate/erm-ii-eus-exchange-rate-mechanism_en> (last retrieved on 2 March 2018).

41 Article 6(3) of Regulation 1175/2011 sets out the criteria to be taken into account when assessing whether a significant deviation from the adjustment path exists, including: "(a) for a Member State that has not reached the medium-term budgetary objective, when assessing the change in the structural balance, whether the deviation is at least $0,5 \%$ of GDP in a single year or at least $0,25 \%$ of GDP on average per year in 2 consecutive years; (b) when assessing expenditure developments net of discretionary revenue measures, whether the deviation has a total impact on the government balance of at least $0,5 \%$ of GDP in a single year or cumulatively in 2 consecutive years." 
majority voting (RQMV) as the voting procedure to be used in the Council when deciding on sanctioning measures (Articles 4(2), 5(2) and 6(2) of Regulation 1173/2011). RQMV means that a Commission recommendation to impose sanctions on the Member State concerned is deemed to be adopted, unless it is explicitly rejected by the Council by qualified majority within ten days. The reversal of the mode of decision-making in the Council, from regular QMV to reverse QMV, consequently means that the Commission's recommendation to sanction a Member State will now be semi-automatic, meaning that it will be more difficult for Member States to block such a decision from being adopted. ${ }^{42}$ Only Eurozone Member States have a right to vote when the decision concerns another Eurozone Member State and the vote of the Member State concerned is not taken into account (Article 12 of Regulation 1173/2011, but also Article 6(2) of Regulation 1175/2011).

The Fiscal Compact even goes as far as introducing reverse qualified majority voting for all stages of the Excessive Deficit Procedure where Euro area Member States are concerned, even where this was not foreseen by the Six-Pack. Article 7 of the TSCG states that

the Contracting Parties whose currency is the euro commit to support the proposals or recommendations submitted by the European Commission where it considers that a Member State of the European Union whose currency is the euro is in breach of the deficit criterion in the framework of an excessive deficit procedure, [unless] a qualified majority of them, calculated by analogy with the relevant provisions of the European Union Treaties without taking into account the position of the Contracting Party concerned, is opposed to the decision proposed or recommended.

A qualified majority in the Council is thus needed to veto any Commission recommendation under the EDP where it concerns a Euro area Member State, whereas before a qualified majority voting was needed to adopt such recommendation. Overall, it has now, at least in theory, become considerably easier for the Commission to enforce sanctions against Eurozone Member States than against non-Eurozone Member States. The question remains, however, as to whether such sanctions will be deemed politically desirable by the Commission, as it is then on the latter on whom the enforcement will depend. This question is not something that will be further explored here.

Moreover, the Six-Pack introduced the Excessive Imbalance Procedure as the corrective arm of the Macroeconomic Imbalance Procedure (MIP) (Regulation 1176/2011). The EIP is initiated when the Council, upon the recommendation of the Commission and based

42 M. Dawson, “Economic and Monetary Union: Maastricht's Great Failure”, in: M. De Visser, A. P. Van der Mei (eds.), The Treaty on European Union 1993-2013: Reflections from Maastricht, Intersentia: Antwerp, 2013, p. 486. 
on the Alert Mechanism Report and following in-depth reviews within the European Semester framework, establishes the existence of an excessive imbalance in a Member State. In such a case, it may ask the Member State concerned to take corrective action (Article 7 of Regulation 1176/2011). Under Articles 8 and 9 of that same regulation, the Member State concerned may be required to submit its corrective action plan to the Council and the Commission, the implementation of which will be monitored by the Commission. When a Member State has failed to take the recommended corrective action, the Council will adopt a decision establishing such a failure by reverse qualified majority voting (Article 10(4) of Regulation 1176/2011). Thus, the Commission's recommendation - in this case on the non-compliance of the Member State - is considered to be adopted, unless it is rejected by the Council by a majority vote within ten days of its adoption. When such a decision establishing non-compliance is adopted with regard to a Eurozone Member State, Article 3 of Regulation 1174/2011 in turn provides for the right of the Council to impose sanctions on that Member State (acting without the vote of the Member State concerned (Article 5 of Regulation 1174/2011)). Hence, while all Member States can be subjected to the Excessive Imbalance Procedure under Regulation 1176/2011, only Member States that have adopted the Euro may be sanctioned for non-compliance on the basis of Regulation 1174/2011. ${ }^{43}$

By introducing a different and more stringent system of sanctions for the Member States of the Eurozone, the new post-crisis economic governance framework has in effect made non-compliance with EU fiscal and economic rules much more risky for them, which in turn also has an effect on their parliament's freedom to act. Not only are they more constrained in their budgetary procedures in comparison to their non-Eurozone counterparts - especially due to the new limits and requirements introduced by the Two-Pack it is also conceivable that the parliaments of the Eurozone Member States will be more careful to ensure that they comply with EU rules, if they want to avoid sanctions. The effects are, however, not limited to budgetary issues only. They also concern other parliamentary prerogatives, as one cannot necessarily be separated from the other; budgetary constraints cannot, for example, be ignored when deciding on pension reforms, health care reforms or any other form of public expenditure. The new rules thus seem to endow the Council and the Commission with considerable influence, not only on the national budgetary processes but also on general (economic) policy-making of national parliaments in Eurozone Member States.

Further limitations on the room for budgetary maneuver of national parliaments from the Eurozone stem from the two intergovernmental treaties to which the Euro area

43 Article 1 of Regulation 1174/2011 limits the scope of the regulation to Member States whose currency is the Euro; see also: M. Hallerberg, B. Marzinotto, G. Wolff, "An Assessment of the European Semester", (2012) Study for the European Parliament's Committee on Economic and Monetary Affairs, pp. 25-26. 
Member States are contracting parties, i.e., the TSCG and the ESM Treaty. While the TSCG was signed by both Eurozone Member States and non-Eurozone Member States - albeit not by all of them - it is only forcedly binding on the Member States of the Euro area. All other contracting parties will only be bound by its provisions once they have adopted the Euro or if they wish to be bound by them, in which case they may choose the relevant provisions that they wish to comply with. ${ }^{44}$

Hence, while parliaments from outside the Euro area could decide, first of all, whether they wanted to be bound by the provisions of the Fiscal Compact at all, and secondly by which provisions of the treaty exactly and which they were also able to have a say on the extent to which their budgetary powers will be constrained, the parliaments of Eurozone Member States did not have such choice. Moreover, and unlike their non-Eurozone counterparts, they also face limitations imposed on them as a result of their participation in the ESM. National parliaments from those countries that receive financial assistance from the ESM ('debtor states') are extremely limited by the strict terms of conditionality that are stipulated in the Memoranda of Understanding that the Member State signs in return for such assistance. National parliaments of the 'creditor states', i.e. of those Member States providing the financial assistance, on the other hand, must take into account the financial guarantees they have given within the ESM framework when deciding on the future budget, which also limits their room for maneuver, albeit in a different way (see Section 6.2.1.4.1). Non-Eurozone Member States, and thus their parliaments, do not have to face such constraints, as they do not take part in the ESM.

\subsubsection{Within the Eurozone: Weak vs. strong national parliaments}

While the economic governance reform during and following the Euro crisis has further and very notably deepened the dividing line between those Member States that have adopted the Euro and those that have not, and consequently also the line between the national parliaments of those two groups of Member States, this is not the only change in national parliamentary power relations that can be observed. As was mentioned above, before the crisis, national parliaments across all 28 Member States had very different types and degrees of powers in relation to EU affairs. The reasons for this can be attributed to the different domestic constitutional systems of the Member States, which respectively regulate parliamentary participation in EU affairs in very different ways. Having looked at the difference in powers between Eurozone and non-Eurozone parliaments in the previous section, this section will deal with the asymmetry of powers within the Eurozone itself. It will show that not only have parliamentary powers, in and outside the Eurozone, been affected dif-

44 European Commission website, Six-Pack? Two-Pack? Fiscal Compact? A Short Guide to the New Fiscal Governance, available at: <http://ec.europa.eu/economy_finance/articles/governance/2012-03-14_six_ pack_en.htm> (last retrieved on 1 May 2016). 
ferently by the crisis, but it will also show how the crisis has affected parliamentary powers within the Eurozone itself. This 'disintegration' of national parliamentary powers could first of all be seen between those parliaments which have historically had a strong involvement in EU affairs and those which have not, as the gap between the two seems to have widened as a result of the crisis. The second line of asymmetry can be seen between those parliaments whose Member State was in financial difficulty and had to request financial assistance and those parliaments whose Member States did comparatively well to mitigate the effects of the crisis, economically speaking at least. Or to put it differently, national parliaments from economically strong Member States were affected differently by the crisis when compared to national parliaments from economically weak Member States.

\subsubsection{Asymmetry according to institutional strength}

National parliaments, as the traditional lawmakers in the context of the nation-state, have lost many decision-making powers to the Council of Ministers, and also the European Parliament, as a result of the European integration process and the subsequent transfer of powers from the national to the European level. ${ }^{45}$ This loss of powers has arguably increased during the resolution of the financial crisis, with many decisions being taken in the European Council, which not only bypassed the European Parliament but also the national parliaments due to the urgent nature of the decisions. With regards to European Union affairs, national parliaments have three main functions: ratifying EU Treaties, implementing EU legislation into domestic law and, last but not least, holding the executive to account at EU level. ${ }^{46}$ This section will not concern itself with the second function, but rather it will focus on how the role of national parliaments has been affected by the crisis, when it comes to ratifying intergovernmental treaties such as the Treaty on Stability, Coordination and Governance in the Economic and Monetary Union or European Stability Mechanism Treaty as well as when it comes to holding their government to account for decisions that were taken in the (European) Council during the crisis.

\subsection{Ratification of intergovernmental treaties}

While all European Union Treaties, as well as intergovernmental treaties such as the Treaty on Stability, Coordination and Governance in the Economic and Monetary Union or European Stability Mechanism Treaty, are subject to ratification by the Member States' parliaments, the ratification powers of the latter are a matter of domestic constitutional law. ${ }^{47}$ Thus, the ratification procedure can - and does - differ from one Member State to

45 Kiiver, supra note 1, p. 10.

46 Ibid.

47 The Treaties simply stipulate a ratification "by all Member States in accordance with their respective constitutional requirements" (Article 48 TEU). 
the next, and can range from a simple majority vote (United Kingdom) to super-majorities of two-thirds or three-fifths majority to the requirement of a referendum, in which case the national parliament is actually not involved at all. ${ }^{48}$

One the one hand, it can be argued that the use of intergovernmental treaties strengthens national parliamentary involvement and also their input legitimacy because they need to be approved by each national parliament or by a referendum, as opposed to EU measures that are adopted on the basis of the Community method. ${ }^{49}$ The issue is, however, that not every national parliament had the same degree of choice as to whether to ratify the TSCG or the ESM Treaty, and also the amount of time for deliberation differed from one parliament to the next. For example, because in Greece it was considered that there was little alternative to signing the Fiscal Compact, if bankruptcy were to be avoided, the Greek parliament was the first to ratify the TSCG with the vote taking place in one day on 28 March 2012 together with the vote on ratifying the ESM and Article 136(3) TFEU. ${ }^{50}$ This meant that there was a period of not even four weeks between the signing of the TSCG on 2 March 2012 and the ratification of the bill ratifying the Treaty by the Greek parliament. By way of contrast, in Germany the TSCG was only ratified on 29 June 2012, thus a good three months later than Greece, during which the ratification - in the absence of any pressure from the financial markets - could be extensively debated and even brought before the German Federal Constitutional Court. ${ }^{51}$

\subsection{Participation in EU (crisis) affairs}

As was explained above, the powers of national parliaments with regard to holding their government to account in EU affairs mostly relates to their access to information and their power to influence the government's position in EU negotiations: either through scrutiny reserves or mandating mechanisms, including the power to sanction the government for deviating from its prescribed position. These powers differ from one parliament to the next, depending on the constitutional and legal setting of the Member State concerned. ${ }^{52}$ A variety of political scientists have, throughout the process of EU integration since the 1990s, tried to measure the institutional strengths of national parliaments in EU affairs and to rank them according to their strengths. ${ }^{53}$ While the exact order of the ranking differs

48 Kiiver, supra note 1, p. 11.

49 T. Beukers, "The Eurozone Crisis and the Legitimacy of Differentiated Integration", (2013) EUI Working Papers MWP 2013/36, p. 13.

50 European University Institute website, Constitutional Change through Euro Crisis Law: Greece - Fiscal Compact, available at: <http://eurocrisislaw.eui.eu/country/greece/topic/fiscal-compact/> (last retrieved on 1 May 2016).

51 Benz, supra note 6, p. 135.

52 Höing, supra note 8, p. 11.

53 See, for example: K. Auel, O. Rozenberg, A. Tacea, "Fighting Back? And, If So, How? Measuring Parliamentary Strength and Activity in EU Affairs”, in: C. Hefftler, C. Neuhold, O. Rozenberg, J. Smith (eds.), The Palgrave Handbook of National Parliaments and the European Union, Palgrave Macmillan: United Kingdom, 2015, 
between studies, there seems to be a general consensus that the parliaments of Denmark, Finland, Sweden, Austria and Germany are amongst the strongest, while the parliaments of Belgium, Greece, Cyprus, Ireland (until 2011), ${ }^{54}$ Luxembourg, Portugal and Spain can be found at the bottom end of the rankings. This has not particularly changed during the crisis.

By comparing the activities of national parliaments in general EU affairs - including the number resolutions and mandates issued, the number of committee meetings and plenary debates held, the number of hearings with the head of government in EACs, the number of (reasoned) opinions within the Early Warning System and Political Dialogue, and their activities in crisis-related EU affairs, mainly their participation rights under the EFSF - Auel and Höing found a strong correlation between both activities and arrived at the conclusion that the Euro crisis was generally "business as usual" for national parliaments. ${ }^{55}$ In general, there seems to be a strong correlation between the institutional strength of national parliaments in general EU affairs and their institutional strength in crisis-related matters ${ }^{56}$ meaning that institutionally stronger parliaments either remained strong or became stronger (such as the German Bundestag) during the crisis, whereas institutionally weaker parliaments have remained weak and marginalized. ${ }^{57}$ Coincidentally, it was those Member States with the institutionally weakest parliaments that were also hit the hardest by the crisis: Greece, Cyprus, Spain and Portugal.

In an often-cited overview for the Deutsche Bank Research, Heinen and Theiss have compared the decision-making powers of national parliaments when it comes to deciding on sovereign aid packages under the EFSF and the paying of tranches. ${ }^{58}$ The overview seems to confirm the general groupings of national parliaments with regard to their institutional strengths in general EU affairs. While Spain and Cyprus have no participation rights under the EFSF at all, the Portuguese and Greek parliaments may theoretically vote on financial assistance packages, but it is the finance minister who solely and ultimately decides on the payment of tranches. However, since both Portugal and Greece were recipients of financial assistance, there were actually no votes in parliament. In Germany,

p. 79; T. Winzen, "National Parliamentary Control of European Union Affairs: A Cross-National and Longitudinal Comparison", (2012) 35 West European Politics, p. 665; A. Maurer, W. Wessels, "National Parliaments after Amsterdam: From Slow Adapters to National Players?”, in: A. Maurer, W. Wessels (eds.), National Parliaments on their Ways to Europe: Losers or Latecomers?, Nomos Verlagsgesellschaft: BadenBaden, Germany, 2001, p. 463.

54 There was a constitutional reform in Ireland in 2011, which had the effect of reinforcing the powers of the Oireachtas in EU affairs.

55 K. Auel, O. Höing, "Scrutiny in Challenging Times - National Parliaments in the Eurozone Crisis", (2014) Sieps European Policy Analysis, pp. 9-10.

56 Ibid., pp. 10-11.

57 Ibid., p. 13.

58 N. Heinen, A. Theiss, "EFSF - Where Do National Parliaments Have a Say in the EMU?", (2011) Deutsche Bank Research. 
both the decisions on aid packages and tranches need to be supported by the German Bundestag, and regarding the former, this must be done with the consent of the plenary and for the latter it must be done with the consent of the budgetary committee. ${ }^{59}$

This distinction between institutionally stronger and institutionally weaker national parliaments, understood as their capability to participate in EU affairs, has another, more incidental, consequence. Thus, Benz argues that a strong parliament at the national level also results in a strong national government at the EU level. ${ }^{60}$ For example, the German Bundestag which is regarded as a strong national parliamentary chamber has, over the course of the crisis, acquired extensive participation rights in EU and Euro crisis matters, not least due to the requirements that were set by the German Federal Constitutional Court (see Chapter 4 on the German Bundestag). These parliamentary participation rights constitute a constraint on the government when it is acting at EU level, meaning that the German representatives in both the Council and the European Council are dependent on obtaining the majority support of the Bundestag when they are taking decisions at EU level. While the first impression of this arrangement might be regarded as a certain weakness of the German government at national level vis-à-vis its parliament, at the same time it also provides the former with a stronger negotiating position at EU level, because the governments representative can claim in the Council to bound by their own parliament at home and thus to be unable to change their position in regards a certain matter. A strong national parliament with a tight grip over the government at home can thus turn into a more powerful negotiating position for the government at EU level. ${ }^{61}$ This widens the gap between strong national parliaments and weak national parliaments, because - put simply - the domestically strong position of the national parliament can turn into a strong negotiating position for the national government at EU level, which in turn increases the chances of the parliament's position being enforced vis-à-vis the other Heads of States or Governments or ministers.

\subsection{Control over European Council meetings}

The emergence of the European Council as a decision-making authority has had several implications for the role of national parliaments in the $\mathrm{E}(\mathrm{M}) \mathrm{U}$. Firstly, there is no single institution to which the European Council is accountable, but rather each Head of State or government is accountable to his or her parliament at home, where accountability mechanisms can differ very much from one Member State to the next. Secondly, even when national parliaments have adequate instruments at their disposal to control their Heads of State or Government in the European Council, the latter's ability to achieve an

\footnotetext{
59 Ibid.

60 Benz, supra note 6, p. 136.

61 Ibid.
} 
outcome that would be considered favourable for the Member State which he or she represents are not equal either. In general, the increase in the powers of the European Council during the crisis ${ }^{62}$ posed a challenge for the ability of national parliaments to control their national governments and to participate in EU affairs. This is mainly due to the secrecy and the lack of transparency pertaining to European Council meetings and the urgency under which the Heads of State or Government have met during the crisis, but it also relates to the fact that, so far, national parliaments have adapted to EU integration only with a view to the ordinary legislative procedure. ${ }^{63}$ Thus, while national parliaments have established scrutiny processes for ordinary EU legislation and acquired information and scrutiny rights over their ministers in the Council of the European Union, they were less prepared for such a shift of power to an intergovernmental institution such as the European Council and the smaller Euro Summits, consisting of the Heads of State or Government of the Eurozone States. ${ }^{64}$

According to a study that was commissioned for the European Parliament in 2012, only 17 Member States out of the (then) 27 Member States had enacted specific constitutional rules with regard to the European Council; they mainly relate to the written or oral information rights of the national parliaments concerning European Council procedures and decisions. These Member States are Belgium, Bulgaria, Czech Republic, Denmark, Finland, Germany, Hungary, Italy, Latvia, Lithuania, Luxembourg, Malta, Poland, Portugal, Slovakia, Spain and Sweden. ${ }^{65}$ Estonia, Lithuania, Latvia, Slovenia, Slovakia and Sweden go even further by requiring the representative in the European Council to consult parliament and ask for the latter's opinion in relation to matters. ${ }^{66}$ In Lithuania, the parliamentary opinion is binding. ${ }^{67}$

While the report notes that there has been a shift towards an increased ex ante control of European Council meetings in an attempt of parliaments to influence decisions at EU level, ex post control is still being carried out more often. Accordingly, the overall number of ex post plenary debates after European Council meetings are higher than those which take place before European Council meetings. ${ }^{68}$ In general terms, the report also found that parliaments with more extensive participation rights in general EU affairs are also those parliaments that are much more extensively involved in the ex ante control of

62 See on executive dominance in general: D. Curtin, "Challenging Executive Dominance in European Democracy”, (2013) Amsterdam Centre for European Law and Governance Working Paper Series 2013-09; J. Habermas, The Crisis of the European Union: A Response, Polity Press: United Kingdom, 2012.

63 W. Wessels, O. Rozenberg, M. Van den Berge, C. Hefftler, V. Kreilinger, L. Ventura, "Democratic Control in the Member States of the European Council and the Euro Zone Summits", (2013) Study for the European Parliament's Committee on Constitutional Affairs, p. 16.

64 Ibid.

65 Ibid., pp. 30-31.

66 Ibid.

67 Ibid.

68 Ibid., p. 39. 
European Council meetings. ${ }^{69}$ Such a correlation, however, could not be found in relation to ex post control. ${ }^{70}$ There is also a differentiation to be made between ex ante control at plenary level and ex ante control at committee level. ${ }^{71}$ Thus, Ireland, France and the Netherlands have the highest number of ex ante plenary debates, but no ex ante debates are carried out at committee level. ${ }^{72}$ Conversely, Belgium, Sweden, Estonia, Finland, Portugal, Lithuania, Slovakia, Latvia and Italy only have committee debates before European Council meetings and no regular plenary debates, while the Danish and German parliaments are active ex ante in both the plenary and the committees. ${ }^{73}$

Out of these countries, with a high number of activities before European Council meetings, only Ireland and Denmark are regularly engaged in ex post debates at plenary level. France and Germany focus more on ex post committee debates, while the Dutch parliament only holds "ex post debates in exceptional cases." ${ }^{74}$ This could possibly be explained by the fact that the European Council meetings are already extensively dealt with in plenary before they take place, which does not leave much time, or indeed desire, for the MPs to deal with it again thereafter. ${ }^{75}$ In all of the Member States that were analyzed in the report, it found that only Malta and Romania did not deal with European Council meetings ex post or ex ante at either plenary or committee level. ${ }^{76}$

\subsection{Control over Euro summits}

However, most Member States do not differentiate between regular Council meetings and other meetings like Euro summit meetings; ${ }^{77}$ only in Germany, Austria and Spain are there rules relating to the Euro summits. ${ }^{78}$ In the other Member States, the control of Euro summits is not entirely clear. In many Member States, the scrutiny mechanisms of parliament $v i s-\grave{a}$-vis the Euro summits seems to be similar to the mechanisms that are applicable to European Council meetings or to EU affairs in general. ${ }^{79}$ According to the report of the European Parliament, national parliaments tend to include discussions on Euro summits in their debates on the European Council meetings, if they happen to occur at the same time. Thus, a Euro summit in July 2011, for example, did not take place in connection with any other meeting and had "the lowest number of debates, governmental declaration or

\footnotetext{
69 Ibid., p. 37.

$70 \quad$ Ibid., p. 39.

$71 \quad$ Ibid., p. 37.

72 Ibid., pp. 38-39.

73 Ibid.

74 Ibid., p. 40.

75 Ibid.

76 Ibid.

77 Ibid., p. 31.

78 Ibid., p. 32.

79 Ibid.
} 
votes in all parliaments - even if this is also to be explained by the fact that in mid-July many parliaments are in summer recess already." ${ }^{\prime 0}$

\subsubsection{Asymmetry according to economic strength}

The ability of Member States, and thus their national parliaments, to shape the decisions that were taken during the Euro crisis also depended, to quite a large extent, on their economic strength. This manifested itself in two ways: the first has a more political dimension, and is the result of the different degrees of bargaining power among the Member States in the European Council and the Euro Summit, which emerged as an (intergovernmental) decision-making authority during the crisis. The second has a more legal dimension and was institutionalized through the European Stability Mechanism, which provides for a different weighting of votes of the participating Member States according to their economic size, but which also draws a fundamental line between those Member States that receive financial assistance under its framework and those Member States that contribute to its funds.

6.2.1.4.1 The European Council and the asymmetric bargaining powers of Member States The bargaining power of Member States in the European Council, which is defined as "the capacity of the national executive to achieve a distributional outcome that as closely as possible reflects the preferences of the Member State he or she represents", depends first and foremost on its structural power resources, i.e., its economic strength, population size, military capabilities, political stability and administrative capacity. ${ }^{81}$ While the institutional and individual sources of power also play a role - such as the presidency of the European Council and the personal qualities of the Head of State or government that is taking part in the negotiations - the first source of power is the most fundamental one, ${ }^{82}$ and it will be the subject of this section's analysis. Tallberg divides state power into two categories first, the state's aggregate structural power, i.e., the total amount of its resources and capabilities in the areas mentioned above, and second, more issue-specific powers in certain policy areas. $^{83}$

In international organizations, the outcome of the negotiation process tends to be dominated by the most powerful states, ${ }^{84}$ and the same applies to European Council negotiations, where "the largest countries have the largest influence", while smaller countries resort to supporting either each other or the large Member States, depending on their own

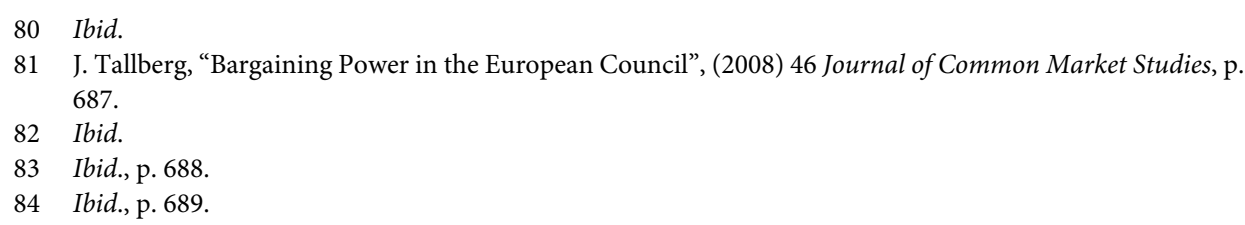


interests. ${ }^{85}$ Thus, Tallberg found out in interviews with high ranking EU officials that a "large home market makes a state more influential in economic negotiations" and that "population size grants voice in an EU conceiving of itself as a democratic community." 86 This results in a situation whereby government representatives from structurally stronger states are granted more latitude in European Council negotiations, and whereby they are able to veto a decision more often, but also more credibly, than their weaker counterparts. ${ }^{87}$

When it comes to issue-specific powers, the "State's resources in a particular issue, its commitment to this issue and its alternatives to a negotiated agreement on this issue" will also play a role in the negotiation process. Thus, while Germany plays a more restricted role in the domain of EU foreign and security policies, especially when compared to the United Kingdom or France, ${ }^{88}$ it has - as the largest and most prosperous Member State shaped the economic policies of the European Union to a non-negligible extent. ${ }^{89}$ In the European Council, different economic strength translates into different negotiation positions - or inequality - of Member States. ${ }^{90}$ The bargaining power of a Member State in economic affairs is dependent on its market power and gross domestic product (GDP), ${ }^{91}$ but also on the sustainability of its budget and government debts. As an example, while Italy has historically had a high GDP, it still lost some of its bargaining power with regard to economic affairs because of its persistent budget deficit and growing debt. ${ }^{92}$ As a consequence, it seems that the most influential Member States in European Council negotiations when it comes to economic governance in the EU are those Member States with the highest GDP and the lowest government deficits and debts. During the Euro crisis, this was Germany and France.

Together, Germany and France have, during the height of the crisis between 2009 and 2012, become the decisive authority in questions relating to EU financial policy. ${ }^{93}$ This dynamic was reinforced by their practice of meeting on a bilateral basis before the European Council summits so as to agree on an arrangement that was later to be adopted by the whole European Council. ${ }^{94}$ Even though Member States in the European Council are equal

85 M. Heipertz, A. Verdun, Ruling Europe - The Politics of the Stability and Growth Pact, Cambridge University Press: United Kingdom, 2010, p. 20.

86 Tallberg, supra note 81, p. 690.

87 Ibid., pp. 690-691.

88 Ibid., p. 693.

89 F. Fabbrini, Economic Governance in Europe: Comparative Paradoxes and Constitutional Challenges, Oxford University Press: United Kingdom, 2016, p. 125.

90 J. Pollak, “Compounded Representation in the EU: No Country for Old Parliaments?", in: S. Kröger (ed.), Political Representation in the European Union - Still Democratic in Times of Crisis?, Routledge: United Kingdom, 2014, pp. 23-24.

91 Tallberg, supra note 81, p. 693.

92 Ibid.

93 S. Fabbrini, "Intergovernmentalism and Its Limits: Assessing the European Union's Answer to the Euro Crisis", (2013) 46 Comparative Political Studies, p. 1008.

94 Ibid., p. 1009; Fabbrini, supra note 89, p. 125. 
in the sense that each Member State has one representative with one vote, in reality this is not the case and it was especially not the case during the crisis. Instead, the "[FrancoGerman] axis was [...] always an expression of inequality between the Member States."95 When, however, the economic situation in France began to deteriorate, it was Germany - as the biggest and economically strongest Member State - that became the dominant decision-making party in economic policy matters in the European Council. ${ }^{96}$

Overall, the emergence of the European Council as the intergovernmental decisionmaking authority in economic affairs during the Euro crisis has had as an effect on the strengthening of the position of the larger Member States and, more specifically, the economically powerful Member States. During the crisis, this Member State was Germany. ${ }^{97}$ This development is furthermore reinforced by the lack of a supranational institution, which do not represent national interests, such as the European Commission or the European Parliament, and which would be able to mitigate the differences in power imbalances between the different Member States. ${ }^{98}$ This inequality of Member States' bargaining powers in European Council negotiations also indirectly affects their national parliaments. No amount of control or influence over their Head of State or Government will do parliament any good, if the former is not able to enforce the latter's view at EU level against larger or more prosperous Member States. National parliamentary influence on EU policy-making will hence also depend, to a certain extent, on the population size along with the economic size of the Member State in question, which will have an effect on whether or not the executive will be able to push through its interests during European Council negotiations. This is even more so the more decisions are transferred from supranational institutions to intergovernmental institutions, such as the European Council and the Euro Summit, as was commonplace throughout the Euro crisis.

\subsection{Institutionalized asymmetric powers between 'creditor' and 'debtor' countries} The second way in which the economic size of a Member State affects its national parliamentary powers is more institutionalized and it is largely based on the provisions of the European Stability Mechanism. For one, there is a fundamental distinction between socalled 'debtor countries' and 'creditor countries', i.e., those Member States that receive financial assistance from the ESM and those that contribute to its funds. Not only has the crisis affected the different Member States in different ways, but it has also had a diverging impact on their respective parliaments and the latter's powers, depending on whether they received or provided financial assistance. ${ }^{99}$ And secondly, there is also a differentiation to

95 Pollak, supra note 90, pp. 23-24.

96 Fabbrini, supra note 89, p. 125.

97 Ibid., p. 128.

98 Ibid., p. 125.

99 Höing, supra note 8, p. 4. 
be made within the creditor countries themselves, as the size of their contribution to the ESM - which depends on their GDP - has an effect on the weight of their votes in certain decisions that have been taken by qualified majority voting.

The ESM is a permanent rescue mechanism that has been established between the Euro Member States with the following objective:

to mobilize funding and to provide stability support under strict conditionality, appropriate to the financial assistance instrument chosen, to the benefit of ESM members which are experiencing, or are threatened by, sever financing problems, if indispensible to safeguard the financial stability of the euro area as a whole and of its Member States. ${ }^{100}$

It thus provides loans to Member States that are in - or threatened by - financial difficulties at interest rates that are much lower than they would be in normal financial markets. The ESM replaced the temporary European Financial Stability Facility, which was established in June 2010 and which provided financial assistance to Ireland, Portugal and Greece in October 2012 and which has also provided loans to Spain, Cyprus and Greece. ${ }^{101}$

Under Article 136 TFEU and the ESM Treaty, financial assistance is subject to strict conditionality and linked to the implementation of policy conditions by the Member State receiving the assistance. These policy conditions are specified in Memoranda of Understanding that have been concluded between the European Commission, the European Central Bank, and the International Monetary Fund - which together constitute the socalled Troika - and the beneficiary Member State. The procedure for the granting of financial assistance is specified by Article 13 of the ESM Treaty. If an ESM member requests stability support following a request to the Board of Governors - which consists of the Ministers of Finance of the Euro Member States ("member of the government [...] who has responsibility for finance"102 - the Chairperson of the Board of Governors asks the European Commission, together with the ECB and possibly the IMF, to assess whether a risk to the financial stability of the Euro area as a whole exists and whether public debt is sustainable and to assess the actual or potential financing needs of the ESM member concerned (Article 13(1) of the ESM Treaty). Based on this assessment, it is then for the Board of Governors to decide whether they will grant financial assistance to the ESM member concerned (Article 13(2) ESM Treaty), following which the European Commission, together with the ECB and IMF, will negotiate the MoU with the beneficiary Member State detailing the conditionality attached to the financial assistance (Article 13(3) of the ESM Treaty).

100 Article 3 of the ESM Treaty.

101 European Financial Stability Facility website, About EFSF, available at: <www.efsf.europa.eu/aut/index.htm> (last retrieved on 1 May 2016).

102 Article 5(1) of the ESM Treaty. 
The MoU is then signed by the European Commission on behalf of the ESM with the approval of the Board of Governors, while the Board of Directors ${ }^{103}$ has the task of approving - after the adoption by the Board of Governors - the financial assistance facility agreement that will set out the financial aspects of the stability support. ${ }^{104}$

In general, the decision of the Board of Governors to provide stability support to a Member State and to give a mandate to the European Commission to negotiate, together with the ECB, the economic policy conditionality attached thereto is taken by mutual agreement (Article 5(6)(f) and (g) of the ESM Treaty), i.e., by unanimity. ${ }^{105}$ If however, the Commission and the ECB find in a certain case that a failure to urgently adopt a decision to grant or implement financial assistance would threaten the economic and financial sustainability of the Euro area as a whole, a decision can be adopted with a qualified majority of $85 \%$ of the votes cast (Article $4(4)$ of the ESM Treaty). Decisions to be taken by the Board of Governors, other than the emergency procedure which requires a qualified majority in the Board of Governors, are listed under Article 5(7) of the ESM Treaty and include, for example, the approval of the annual accounts of the ESM, the appointment of the members of the Board of Auditors, or the waiver of the immunity of the chairpersons of the various bodies of the ESM. Here, in order to take a decision with a qualified majority, $80 \%$ of the votes cast is required (Article $4(5)$ of the ESM Treaty).

The share of votes of each ESM Member State is equal to its share in the authorized capital stock of the ESM (Article 4(7) of the ESM Treaty). ${ }^{106}$ The contribution of each Member State to the ESM authorized capital stock is calculated on the basis of the key for capital subscription by the national central banks of the ESM members to the ECB's capital (Article 11(1) of the ESM Treaty), which in turn is determined based on the combination of the Member States' population size and its GDP (Article 29 of Protocol $\mathrm{No}^{\circ} 4$ on the ESCB Statute). Thus, the largest Member States, both in terms of population size and GDP, pay the largest share to the ESM capital stock (the contribution key of the ESM and a detailed listing of the subscriptions of each ESM member to the authorized capital stock is listed in Annexes I and II of the ESM Treaty). This also means that the largest Member States, both in terms of population size and GDP, receive the highest share of votes under the qualified majority voting system in the context of the emergency voting procedure. In practice this has the effect that the German representative and the French representative - as the ESM members with the highest share in the authorized capital stock $^{107}$ - can

103 Each Governor appoints one Director "from among people of high competence in economic and financial matters" (Article 6(1) of the ESM Treaty).

104 Articles 13(3) and (5) of the ESM Treaty.

105 Article 4(3) of the ESM Treaty; abstentions do not prevent a decision from being adopted by mutual agreement.

106 The authorized capital stock is $€ 700000$ million (Article 8 of the ESM Treaty).

107 Germany's capital subscription is a little more than $€ 190$ million, while France's is almost $€ 143$ million (Annex II). 
effectively veto a decision, both under the emergency voting procedure as per Article 4(4) of the ESM Treaty and the normal qualified majority voting procedures, because their contributions are so high that they translate into more than $20 \%$ of the votes under QMV. As can be seen in Annex I, Germany's contribution to the ESM under the contribution key is $26.96 \%$, whereas France's contribution is $20.247 \%$, which translates directly into their respective share of voting rights according to Article 4(7) of the ESM Treaty. Both Germany and France are consequently able to prevent the attainment of the required $80 \%$ and $85 \%$ majority of the votes cast respectively. ${ }^{108}$ The only other member that can veto a decision under the normal QMV procedure is Italy, as it has a contribution share and thus voting rights amounting to $17.79 \%$, which, however, is not sufficient to veto decisions under the emergency procedure.

In addition, Article 4(8) of the ESM Treaty provides for the suspension of voting rights of ESM members that fail to pay either the paid-in shares or calls of capitals for as long as that failure persists. This means that Member States that find themselves unable to meet their financial obligations under the ESM due to an economic downturn might also lose their voting rights and thus any influence on the decisions taken in the ESM as a consequence. This is, in general terms, probably more likely to happen to a less prosperous Member State than to a Member State with a high GDP and lower debt levels.

Overall, in certain situations, it is possible that under the ESM Treaty certain decisions can be blocked by Member States that are bigger in economic size due to the resulting higher share of votes in the ESM, while economically weaker members run the risk of losing their voting rights, should they become unable to pay their shares at some point. This in turn has an effect on the powers of the national parliaments in the ESM Member States, i.e., in the Eurozone. Again, the ability of a parliament to influence the decisionmaking process at the supranational or intergovernmental level also depends on the ability of the government representative to enforce the former's opinion in negotiations. Due to the allocation of votes in the ESM, this means that in the end it is only the French and the German parliament that indirectly have a veto right in the ESM, at least insofar as qualified majority voting applies. Thus,

the weakness or strength of a parliament in controlling the operation of the ESM relies on purely economic grounds and in particular on the share capital that each Member State has in the Fund, this being proportionate to its decisionmaking powers. ${ }^{109}$

108 Dawson also talks about an "asymmetric sovereignty transfer" in this regard. See: M. Dawson, "The Legal and Political Accountability Structure of 'Post-Crisis' EU Economic Governance”, (2015) Journal of Common Market Studies, p. 981.

109 Fasone, supra note 3, p. 18. 
The difference in the powers of national parliaments under the ESM is even more pronounced between those ESM members that have requested financial assistance and those ESM members that are considered 'creditor countries'. Because of the strict conditionality that is imposed on the beneficiary Member State that receives financial assistance under the ESM, the latter's national parliamentary room for maneuver becomes severely limited. Member States in financial difficulty have no choice but to accept and to implement the conditions, as they are drawn up by the Commission and monitored by the Troika, in exchange for the financial assistance. The conditions imposed on the debtor countries were "extremely tough and rigid rules of fiscal austerity and detailed requirements for 'structural reforms' to deregulate and liberalize labor and service markets", ${ }^{110}$ which did not leave much freedom to the national parliament of the state in question to adopt policy choices in such matters. Instead, they had to abide by the policy conditions that were deemed feasible by the Commission and acceptable by the creditor states, in which Germany, with the largest contribution to the ESM, had a decisive voice. ${ }^{111}$ Under the threat of insolvency, the possibilities of objecting to the Memorandum of Understanding were rather limited, leading to a situation whereby the national parliaments of debtor states had to trade their autonomy with the requirements made by an unelected institution such as the European Commission and by the governments of other Member States in exchange for the prevention of insolvency.

Overall, it seems that the ESM and the intergovernmental mode of decision-making during the crisis has benefitted the larger and creditor Member States and that this has been done to the detriment of the smaller and debtor states. ${ }^{112}$ This in turn also has consequences for the powers and autonomy of the respective national parliaments. But while it seems clear that the parliaments of (economically) smaller and debtor states have suffered a considerable loss of power as a consequence of the crisis response regime, it should also be noted that the national parliaments of creditor countries have been limited in their freedom as well. By accepting the commitments needed for the rescue funds, they have also accepted a non-negligible limitation on their room of maneuver with regard to future budgets.

\subsubsection{Non-Eurozone: TSCG signatories vs. non-signatories}

The third differentiation to be made concerns the impact that the Treaty on Stability, Coordination and Governance in the Economic and Monetary Union has had on the powers of the national parliaments of the signatory states, notably the non-Eurozone

110 F. Scharpf, "No Exit From the Euro-Rescuing Trap?", (2014) MPIfG Discussion Paper 14/4, pp. 9-10.

111 Ibid.

112 Fabbrini, supra note 93, p. 1022. 
Member States (as the situation of the Eurozone Member States was already analyzed above). As was mentioned before, the Fiscal Compact largely restates the debt rules that are stipulated in the Six-Pack, albeit with more stringent requirements. Contracting states must have a lower structural deficit of $0,5 \%$ of GDP and have a correction mechanism in place, that is to be triggered automatically if a significant deviation from the adjustment path is observed (Article 3(1) of the TSCG). Moreover, the Fiscal Compact requires its contracting parties to transpose the balanced budget rule into national law "through provisions of binding force and permanent character, preferably constitutional, or otherwise guaranteed to be fully respected and adhered to throughout the national budgetary processes" (Article 3(2) of the TSCG).

While all Eurozone Member States had to sign and ratify the TSCG, which is forcibly binding on them, all of the other Member States had a choice in whether to become a contracting party to the Treaty or not, and to decide which provisions they wanted to be bound by. ${ }^{113}$ Thus far, most non-Eurozone Member States have signed the contract, with the exception of the Czech Republic, the United Kingdom and Croatia. Not all of them are bound by the entirety of the Treaty, however. Article 14(5) of the TSCG states that the Treaty only applies to non-Eurozone Member States ("Contracting Parties with a derogation [...] or an exemption") to the extent that they have declared their intention to be bound by all or parts of Title III (Fiscal Compact) and IV (Economic Coordination and Convergence) or where they have adopted the Euro as their currency, in which case they would be bound by the entire Treaty in the same manner as Eurozone Member States.

While Romania ${ }^{114}$ and Denmark ${ }^{115}$ have declared that all the provisions of Titles III and IV of the TSCG will be binding on them, Bulgaria ${ }^{116}$ has opted out of Title IV and will only be bound by Title III, which concerns the budgetary rules under Articles 3 to 8 of the TSCG. Hungary, Lithuania and Sweden, in turn, have opted out of both Titles III and IV and are only bound by Title V of the TSCG, which relates to the governance of the Euro area. Under this title, and in accordance with Article 12(3) of the TSCG, the Heads of State or Government of the non-Eurozone Member States have the right to

113 European Commission website, Six-Pack? Two-Pack? Fiscal Compact? A Short Guide to the New Fiscal Governance, available at: <http://ec.europa.eu/economy_finance/articles/governance/2012-03-14_six_ pack_en.htm> (last retrieved on 1 May 2016).

114 European Council website, Declaration Romania, available at: <www.consilium.europa.eu/en/documentspublications/agreements-conventions/ratification/? $\mathrm{v}=\mathrm{decl} \& \mathrm{aid}=2012008 \& \mathrm{pid}=\mathrm{RO}>$ (last retrieved on 1 May 2016).

115 European Council website, Declaration Denmark, available at: www.consilium.europa.eu/en/documentspublications/agreements-conventions/ratification/ $\mathrm{v}=\mathrm{decl} \& \mathrm{aid}=2012008 \& \mathrm{pid}=\mathrm{DK}>$ (last retrieved on 1 May 2016).

116 European Council website, Declaration Bulgaria, available at: <www.consilium.europa.eu/en/documentspublications/agreements-conventions/ratification/? $\mathrm{v}=\mathrm{decl} \& \mathrm{aid}=2012008 \& \mathrm{pid}=\mathrm{BG}>$ (last retrieved on 1 May 2016). 
participate in discussions of Euro Summit meetings concerning competitiveness for the Contracting Parties, the modification of the global architecture of the euro area and the fundamental rules that will apply to it in the future, as well as, when appropriate and at least once a year, in discussions on specific issues of implementation of [the Treaty].

Article 13 of the TSCG, which concerns the Interparliamentary Conference on Economic and Financial Governance, falls under the same title. Therefore, even between the nonEurozone Member States that have ratified the TSCG, certain differences nevertheless exist. Not all of them are bound to the same extent or by the same requirements under the Treaty. So while Romania, Denmark and Bulgaria have accepted to be bound by the balanced budget rule as per Title III of the TSCG, Hungary, Lithuania, and Sweden are under no obligation to adhere to or to incorporate this rule into their national law. Neither do they take part in the economic coordination under Title IV of the TSCG.

Moreover, the impact of the TSCG on the signatory states does not only depend on the extent to which they are willing to be bound by it, but it also depends on whether or not a similar balanced budget rule as is required thereunder already exists within their national constitutions or not (even though they are Eurozone Member States and as such outside the scope of this section, this was the case, for example, for Poland and Germany). ${ }^{117}$ In a similar manner, the impact of the balanced budget rule will also be different for different Member States, according to their debt levels. Member States that already have a balanced budget will remain much more unaffected by Article 3 of the TSCG than those that will have to make a tedious effort to meet the requirements contained in the Fiscal Compact. ${ }^{118}$

Therefore, a distinction can also be drawn between the nine non-Eurozone Member States with regard to whether or not and to what extent they have ratified the TSCG. Three of them, namely the UK, the Czech Republic, and Croatia, are not contracting parties to the Treaty at all, meaning that they are neither subject to the stricter debt rules of the Fiscal Compact nor are they under an obligation to transpose such a balanced budget rule into their national law. Similarly, Hungary, Lithuania and Sweden have also opted out of this requirement and merely take part in Euro area discussions under Title V, while Romania, Denmark, and Bulgaria have all agreed to be bound by the Fiscal Compact and the budgetary rules thereunder. As a consequence, the latter three national parliaments have committed themselves to more stringent constraints on their budgetary powers as opposed to the other six, which are merely bound by the requirements stipulated according to ordinary EU law.

117 Höing, supra note 8, p. 8.

118 Ibid. 


\subsection{CONSEQUENCES FOR EU DUAL STRANDS OF REPRESENTATION}

The asymmetric impact of the Euro crisis on the powers of national parliaments has consequences for the concept of the dual strands of representation in the European Union. Under Article 10(2) TEU, citizens are directly represented at EU level by the European Parliament, while national parliaments provide an indirect way of representation by holding the national executive to account when it is acting at EU level. This latter strand of representation has arguably been somewhat eroded during the crisis.

Many of the measures that were adopted during the crisis have had a lasting impact on the budgetary powers of the national parliaments, even though the impact is much larger on Eurozone Member States than it is on non-Eurozone Member States. The rules under the European Semester, the Six-Pack, the Two-Pack, and the TSCG constitute a considerable limitation on the national parliament's room to maneuver, especially when it comes to the adoption of the budget. In particular, the budgetary processes of the Euro Member States have been subjected to tight surveillance by the European Commission, which has gained a substantial amount of powers in this ambit. Their national parliaments are not only faced with procedural limits due to the strict timeline of the European Semester, but they must now also accept the possible intervention by the Commission into an area that was previously an exclusive national competence. The budgetary processes of the Member States have, in essence, become "Euro-national", ${ }^{119}$ even though this is more so the case for Eurozone Member States than for non-Eurozone Member States. Moreover, under the Excessive Imbalance Procedure the Commission can now also intervene into the economic and social policies of the Member States (and not only into budgetary matters) by means of recommendations.

Sanctions for Eurozone Member States are decided by RQMV under the Six-Pack and the TSCG, without the participation of the Member State concerned. This means that the Commission, again, has become much more powerful in this regard as its decision to impose sanctions on a Member State are now semi-automatic, with the Council having to find a qualified majority if it wishes to object to such a decision. This arrangement makes the imposition of sanctions less political by essentially transferring the decision-making power from the Council to the Commission, at least for Eurozone Member States. It also means that, in order to object to such Commission recommendations, the vote of a higher number of ministers from the other Member States than before is required. Depending on the domestic legal framework under which the ministers operate, the latter might in turn be dependent on parliament's position at home. This would ultimately make the objection to a Commission recommendation to impose sanctions on a Eurozone Member State dependent on the will of the national parliaments of the other Member States, at least

119 Fasone, supra note 3, p. 10. 
where the domestic law of the latter gives them the power to mandate their government in such decisions.

It can be argued that this development does not, in fact, pose a problem. The concept of the dual strands of democratic legitimacy has always been based on the assumption that national parliaments have different rights and powers when holding their government to account in EU affairs, with the Treaties being conspicuously silent on this matter. They merely stipulate that the Heads of State or Government as well as the government are "themselves democratically accountable to their national Parliaments, or to their citizens."120 The details of the accountability relationship between parliament and government are (perhaps deliberately?) left for national constitutional law to define. This is, however, exactly where the problem lies. Before the crisis, it could be argued, and rightly so, that differentiated national parliamentary powers in EU affairs were inherent in the nature of the EU constitutional design and as such a willingly accepted fact, because different national constitutions and constitutional traditions provide for different accountability and participation mechanisms. The differences in powers between the national parliaments under the new economic governance framework, however, can no longer be accorded to domestic constitutional law alone anymore.

Instead, it is now a combination of the national parliament's position under domestic constitutional law vis-à-vis its government (institutional strength) and of the Member State in question's financial situation (economic strength) that defines the ability of parliament to hold their government democratically accountable, as is stipulated under Article 10(2) TEU. In particular, the rise of the European Council as an intergovernmental decisionmaking body has drawn a clear line between bigger and more prosperous Member States and smaller and less prosperous Member States, with the former having a much stronger bargaining position in the negotiations. This in turn can be beneficial to their parliaments at home, because they are in a better position to enforce the parliamentary will in the negotiations than is possible for their weaker counterparts. It is thus those national parliaments with a tight grip on the executive under domestic constitutional law that also happen to come from an economically strong Member State with a large population size that have the best chances of seeing their own position enforced at EU level. By way of contrast, parliaments that are accorded very few participation and scrutiny rights under national constitutional law and whose Member States find themselves in severe economic difficulty do not only have weaker rights, at least domestically, to influence the government's position. But even where they do have an influence on the government's positions, it does not mean that the government itself would not still have to concede to the position of other Member States that are economically better off. The European Stability Mechanism reinforces this difference between economically stronger and economically weaker Member States.

120 Article 10(2) TEU. 
Normally, under the ordinary EU decision-making processes, this difference would, to a certain extent, be mitigated by the involvement of supranational institutions. Qualified majority voting in the Council lessens the effect of differences in population size and economic strength between the Member States. The European Commission and the European Parliament do not represent national interests, but rather the interests of the Union and the Union citizens respectively. The crisis and the reactions thereto have, often due to its urgent nature, usurped this institutional balance in favour of certain core Member States so as to enforce their own ideas of how the crisis should be handled. ${ }^{121}$ So while parliaments in Member States such as France and Germany could benefit from the intergovernmentalist approach to crisis resolution, other parliaments, most notably those from Southern European Member States, had to "surrender to strong executives and external pressure." 122 This division of national parliaments into what could be called first-class and second-class parliaments poses a challenge to the concept of dual legitimacy, because it implies that democracy and legitimacy in the EU do not have the same meaning for all Union citizens, but rather that they depend very much on the Member State that they are from. This imbalance of national parliamentary powers that was visible during, and arguably exacerbated by, the crisis has led to what Benz calls a "divided democracy"123 in the EU and the European Parliament does not seem able to counterbalance this divide between the different national parliaments. Quite the opposite is true, it rather seems as if the EP itself is too concerned with strengthening, or at least maintaining, its struggling role in the EMU and the new economic governance framework for it to be able to mitigate the differences between the national parliaments and to provide adequate and equal representation to all Union citizens.

\subsection{Concluding Remarks}

Overall, the Euro crisis was not only a financial crisis but also a democratic one. The asymmetric impact that it had on the national parliaments in the EU has led to a considerable increase in power imbalance between them, and to a situation whereby democracy may no longer be the same for every Member State and every citizen within the EU. Instead, decisions are taken by a few core Member States, and some of their parliaments, while all other parliaments have to accept such decisions as a fait accomplit. This poses a challenge to the concept of dual legitimacy and so far the EP has been relatively unsuccessful in counterbalancing this divide of powers between the national parliaments.

121 E. Fossum, “The Structure of EU Representation and the Crisis”, in: S. Kröger (ed.), Political Representation in the European Union - Still Democratic in Times of Crisis?, Routledge: United Kingdom, 2014, p. 62.

122 Benz, supra note 6, p. 139.

123 Ibid., p. 135. 


\section{REPRESENTATIVE DEMOCRACY IN THE EU - WHICH WAY FORWARD?}

\subsection{INTRODUCTION}

The last chapter has shown that the Euro crisis has had an asymmetric impact on the national parliamentary powers in the European Union and has led to a considerable power imbalance between Member States. Democratic control or influence on decisions taken at EU level is not the same for each Member State, as it depends, to a large extent and amongst others, on their economic position. This imbalance of powers results in a situation of divided democracy, whereby the notion of democracy does not have the same meaning for all EU citizens. The intergovernmentalist approach has made it difficult for national parliaments to hold their governments to account for their actions at the European level and these difficulties have been partially reinforced by the Euro crisis, with some governments - as the representatives of the citizens of their respective Member State - dominating decisions that by their very nature have an impact on the citizens of another Member State. This problem of the disrupted, but also asymmetric, chain of accountability between the different national governments and their electorates at home does not envisage a counterbalance through clear accountability mechanisms at EU level. The question therefore poses itself as to whether and how the parliamentary structures in the European Union, and more specifically in the Eurozone where the majority of asymmetries exist, should be redesigned so as to ensure the adequate and balanced representation of interests of all citizens in the European Union.

Different ideas have been postulated when it comes to parliamentary involvement in the Economic and Monetary Union (EMU). Recently, the French President reiterated his idea, which can also be found in his election programme of 2017, ${ }^{1}$ of creating a Eurozone finance minister, who would be responsible for a Eurozone budget, which is in turn decided by a Eurozone parliament. He, in essence, suggests establishing a Eurozone government with its own parliament and its own minister. The advantage of such a reform would be the full accountability of the proposed Eurozone finance minister to the newly established Eurozone parliament. Such a parliament could either be a second parliamentary chamber, a Euro-Chamber so to speak, composed of national parliamentarians and who are accorded the role of scrutinizing a new Euro-government. Or it could be established as a Euro-Par-

1 E. Macron, Programme En Marche! - Élection Présidentielle 23 Avril et 7 Mai 2017, available at: $<$ https://storage.googleapis.com/en-marche-fr/COMMUNICATION/Programme-Emmanuel-Macron.pdf> (last retrieved on 1 November 2017), p. 21. 
liament, in addition to the current European Parliament, which would be composed of both MEPs and MPs from the parliaments of the Eurozone Member States.

Alternatively, another suggestion that has been considered in this regard is to make use of the existing European Parliament and to subject EMU decision-making to the ordinary legislative procedure in order to equalize the European Parliament with the Council in this ambit. The reasoning behind this proposal is that a fully involved European Parliament can replace, and thus counterbalance, the asymmetric participation of national parliaments, especially if the equalization of the EP is accompanied with wide-ranging accountability powers.

A third idea that has been put forward by, for example, the Future of Euro Group in $2012{ }^{2}$ is a European Parliament operating on the basis of differentiated integration, meaning that only MEPs from Eurozone Member States would be allowed to vote on EMU matters.

A fourth option, which would not require the creation of a separate institution would be the creation of a Euro-Committee within the EP itself, which would have the competence to take decisions on Eurozone matters on behalf of the European Parliament.

The last possibility is a more extensive use of interparliamentary cooperation in EMU matters, primarily through the conference of the European Parliament and the national parliaments under Article 13 of the Treaty on Stability, Coordination and Governance in the Economic and Monetary Union (TSCG), with the objective of promoting mutual information exchange and facilitating joint discussion of Eurozone matters.

The purpose of this chapter is twofold: firstly, it will describe how the principle of representative democracy in the EU was challenged by the Euro crisis and by the imbalances in parliamentary powers as exacerbated by the latter. Secondly, it will assess in turn the different options proposed in relation to the restructuring of the role of parliaments in the EU and EMU, including their respective advantages and disadvantages, if they were to be implemented.

\subsection{REPRESENTATIVE DEMOCRACY IN THE EU}

The concept of representative democracy was already discussed in greater detail in Chapter 2 of this book. Therefore, only a brief summary will be given in this part. In general, representative democracy entails the election of representatives at regular intervals by those who are represented. The representatives thereby fulfill two roles, namely representation and responsibility. Representation means that that the representatives must act in a manner that is responsive to those by whom they have been elected to represent. This is ensured

2 The group consists of the Foreign Ministers of Austria, Belgium, Denmark, France, Italy, Germany, Luxembourg, the Netherlands, Poland, Portugal and Spain. 
through institutional arrangements such as the regular election of a parliamentary assembly. Responsibility, on the other hand, concerns the capability of the representatives to take decisions on behalf of those who they represent. A national government exercises its responsibility in this context by taking unilateral decisions in a given policy area. This becomes all the more difficult the more this policy area is intertwined with the responsibilities of other national governments, namely when responsibility is shared between national governments. An instance of such shared responsibility is the European Union and, within the EU, the Eurozone.

The problem with regards to shared responsibility is that it prevents the national electorate from holding the government to account for actions which do not represent their interests, as the national government does not only take into consideration their own national interests but must also consider the preferences of the other Member States in order to reach a compromise. This wide array of principals in the EU, i.e., the national citizenries of the 28 different Member States, ultimately leads to a dual structure of representation, whereby the citizens of each Member State are, on EU level, indirectly represented as the citizens of their state by their own national parliament and directly represented as European citizens by the European Parliament. This dispersion of representation makes representative democracy in the EU a complicated matter because of the lack of a clear differentiation between the representation of national citizens as EU citizens and the representation of the same citizens as citizens of the different Member States. This becomes especially salient in the functioning of the Council and European Council, the members of which, on the one hand, represent the citizens of their respective Member State, but at the same time collectively function as European institutions furthering European interests. This diffusion of the link between the representatives and those represented also has consequences for democracy in the EMU, which will be further explored below.

\subsubsection{Consequences for representative democracy in the EMU}

Generally speaking, decision-making is democratically legitimate if it can be traced back to the people through an uninterrupted chain of legitimation, thereby ensuring that the people have an effective influence thereon. ${ }^{3}$ In a parliamentary democracy, this means the legitimization of

the exercise of public authority [...] in particular by parliamentary requirements placed on administration, parliament's influence on government policy, and the administration being generally bound by instructions of the government. ${ }^{4}$

3 BVerfG, Judgment of 18 March 2014 - 2 BvR 1390/12, paras. 234-235.

4 Ibid., para. 235. 
In the EU, this link is no longer clearly visible. Because of the decision-making processes of the EU, there can be - and often is - a divergence between the preferences of each national government (and that of their voters) and the actual decision taken by the EU as a collective whole. ${ }^{5}$ It becomes impossible for the voters at home to blame their own government for such divergences in results, because they cannot identify the position taken by each actor throughout the decision-making process, which in turn reduces the accountability of the latter towards their national electorates. ${ }^{6}$ This limited accountability is further reinforced by the fact that voters cannot elect the opposition into office at subsequent elections and expect them to reverse the decisions taken collectively by the previous government, together with 27 other nationally elected governments. This, while conceptually possible for decisions taken in national parliaments at national level, is not possible at EU level. ${ }^{7}$ In short, the main issue is that with regard to the responsive role of government, there is only one principal, namely the voters at national level, whereas with regard to its responsible role, it has to accommodate a variety of preferences and obligations from a variety of different principals. ${ }^{8}$

The problem is that national governments in the EU have to take into account the other Member States' interests as well as remain accountable and responsive to only their own national electorate. This has become even more challenging within the context of the Eurozone. The common currency with a single monetary policy has interlinked the 19 Eurozone Member States to a much larger extent than the 28 (soon 27) EU Member States, both in economic and political terms. Because the national governments of the Euro area are responsible towards each other, as well as co-responsible for the common currency, their room for political maneuver has been increasingly constrained by budgetary and economic commitments that derive from EU law. ${ }^{9}$ Thus, while all national governments in the EU wear a double hat because they are the agents of their national electorate, at the same time they are also (co-) responsible for the collective citizenry of the EU, ${ }^{10}$ it follows that this is much more pronounced for those Member States that share the common currency. $^{11}$

This responsibility also manifests itself in the economic and fiscal rules and requirements, which the EU(rozone) Member States must adhere to and which are adopted at EU (and sometimes international) level. Individual national voters' preferences of the

5 R. Rose, "Responsible Party Government in a World of Interdependence", (2014) 37 West European Politics, p. 258.

6 Ibid.

$7 \quad$ Ibid., p. 259.

8 P. Mair, “Representative versus Responsible Government”, (2009) MPIfG Working Paper 09/8, p. 13.

9 B. Laffan, "Testing Times: The Growing Primacy of Responsibility in the Euro Area", (2014) 37 West European Politics, p. 274.

10 Ibid., pp. 275-276.

11 Ibid., pp. 274-275. 
different Member States are not taken into account in the promulgation of those rules, even though the individual national governments remain accountable to them. They cannot evade responsibility towards their electorate at national level by claiming that there has been a disruption in the chain of accountability as a result of their commitments at EU level. ${ }^{12}$ At the same time, their responsibility towards their national electorate and their simultaneous obligation to fulfill commitments made at EU level and to be responsible towards the other Member States often leads to "cross-pressures", ${ }^{13}$ where not all interests are the same. This means that national governments might be forced, as a result of these external political constraints, to take decisions that neither they nor their own electorates at home would have otherwise taken, because they are no longer in a position to be exclusively responsive to the latter's wishes. ${ }^{14}$

This implies that the national governments of the Eurozone Member States can no longer simply consider their own citizens in isolation. Instead, every fiscal and budgetary decision that is taken should take into account the costs and benefits for all citizens of the Eurozone, including the interests of other Member States. ${ }^{15}$ This is even more important as not all citizens are represented to the same extent in the Council or European Council through their national governments and parliaments, as was shown in the previous chapters. Instead, the degree of representation differs very much from one Member State to the next, depending on their national parliamentary powers in EU affairs, with the most noticeable divide being between citizens from so-called 'debtor countries' and citizens from 'creditor countries'. This unequal degree of representation of the citizens of different Member States has as a consequence an "element of rule of some of the people over others", as opposed to a "rule of the people". "This led to a situation whereby attempts to solve the Euro crisis were neither pan-European solutions involving credit transfers nor was it a solution that satisfied the different national interests/electorates. ${ }^{17}$

The problem of this disrupted, but also asymmetric, chain of accountability between the different national governments and their electorates at home is not counter-balanced by a clear accountability mechanism at EU level either. In Eurozone matters, for example, the Council and European Council work in special formations comprising only represen-

12 Rose, supra note 5, p. 263.

13 Ibid., p. 261.

14 P. Mair, On Parties, Party System and Democracy: Selected Writings of Peter Mair, (edited by I. Van Biezen), ECPR: United Kingdom, 2014, p. 590.

15 S. Piattoni, "Is the EU a Representative Democracy?", in: F. Fabbrini, E. Hirsch Ballin, H. Somsen (eds.), What Form of Government for the European Union and the Eurozone?, Hart Publishing: United Kingdom, 2015, p. 149.

16 P. De Wilde, C. Lord, “Assessing Actually-Existing Trajectories of EU Politicization”, (2016) 39 West European Politics, p. 153.

17 R. Bellamy, D. Castiglione, "Three Models of Democracy, Political Community and Representation in the EU”, (2013) 20 Journal of European Public Policy, p. 207. 
tatives of the Eurozone countries, which have become known as the Eurogroup and the Euro summit respectively. Protocol $\mathrm{No}^{\circ} 14$ on the Eurogroup thus provides that

the ministers of the Member States whose currency is the euro shall meet informally [...], when necessary, to discuss questions related to the specific responsibilities they share with regard to the single currency. ${ }^{18}$

Furthermore, under Article 138 TFEU, only members of the Council representing Eurozone Member States may vote in decisions establishing "common positions on matters of particular interest for economic and monetary union with the competent international financial institutions and conferences" as well as to adopt measures "to ensure unified representation within the international financial institutions and conferences." The Euro summit is a meeting of the Heads of State or Government of the Eurozone Member States. It takes place at least twice a year and is intended for the discussion of "questions relating to the specific responsibilities which [the Eurozone Member States] share with regard to the single currency, other issues concerning the governance of the Euro area and the rules that apply to it, and strategies for the conduct of economic policies to increase convergence in the Euro area." 19

There is no similar differentiation in this regard when it comes to the function of the European Parliament or the European Commission, which are pan-European institutions representing EU (citizens') interests as a whole. This leads to a situation whereby many decisions relating to the Euro, which naturally affect the citizens of the Eurozone Member States, are decided at Eurozone level by the Eurogroup, the Euro summit or the ECB (e.g., ESM or monetary policy decisions), without any corresponding accountability mechanism operating at the same level. Whereas at EU level it follows that the European Commission is responsible towards the European Parliament, both the Council and the European Council, in their different formats, are not collectively responsible towards any other institution. Rather, their members are held accountable by each national parliament in the Member States individually.

Generally speaking, accountability should take place at the level at which a decision is taken. The European Commission, for example, contends that "accountability should be ensured at that level where the respective executive decision is taken, whilst taking due account of the level where the decision has an impact." ${ }^{20}$ Similar commitments can also be found in a European Council conclusion from $2012^{21}$ and in a European Parliament

18 Article 1 of Protocol $\mathrm{No}^{\circ} 14$.

19 Article 12 of the TSCG.

20 European Commission, Communication of 30.11.2012, A Blueprint for a Deep and Genuine Economic and Monetary Union - Launching a European Debate, COM(2012) 777 final/2, p. 35.

21 European Council, Presidency Conclusions, Brussels Council, 13-14 December 2012, EUCO 205/12, p. 5. 
resolution from 2013. ${ }^{22}$ As was mentioned above, this is not the case for decisions taken by the Council or the European Council. Instead, their members are accountable to their national parliaments at home for decisions taken at the European level. The lack of an accountability mechanism at decision-taking level is exacerbated in the Eurozone. While at the European level there is still the European Parliament, which, although it does not hold the European government to account, nevertheless still holds the European Commission to account, there is no corresponding institution with a similar function at Eurozone level.

This in turn means that many citizens are "affected by decisions that are beyond their control and where they cannot hold the decision-makers to account. That raises the spectacle of arbitrary domination. ${ }^{23}$ Fossum calls this input and output incongruence, which he considers to be the result of globalization and a "European integration process driven by executives and experts." ${ }^{24}$ Because citizens are not in a position to hold the Eurogroup or the Euro summit to account for decisions relating to the Euro and the Euro crisis, there is the danger of arbitrary domination of the representatives of some Member States over the citizens over other Member States. ${ }^{25}$ The following part of this chapter will look at the different reform proposals that have been promulgated with the view of making EMU decision-making more representative of the citizens' interests.

\subsection{REFORM PROPOSALS FOR DEMOCRACY IN THE EMU}

Various solutions have been proposed over the past few years on how to rectify the democratic deficit in the EMU. This section will address in turn the different possible scenarios on how to counter the asymmetric impact of the Euro crisis on the strand of democratic legitimacy originating in the national parliaments and discuss their feasibility, advantages and disadvantages respectively.

\subsubsection{Strengthening the position of the European Parliament in the EMU}

One possible way to rectify the democratic deficit in the EMU is by strengthening the role of the European Parliament in EMU matters. This idea entails two different questions. The first question is whether the European Parliament should be fully involved in Eurozone

22 European Parliament, Resolution of 20.12.2013, Constitutional Problems of a Multitier Governance in the European Union, (2012/2078(INI)).

23 J.E. Fossum, "Democracy and Differentiation in Europe", (2015) 22 Journal of European Public Policy, p. 801.

24 Ibid.

25 Ibid. 
matters in the first place and how this would come about, i.e. should the EP be equalized with the Council by subjecting the EMU to the ordinary legislative procedure so as to ensure the former's full participation in any future decision-making processes regarding the Eurozone and should it have more scrutiny powers vis-à-vis an executive taking decisions on behalf of the Eurozone? The second question, on the other hand, rather relates to who within the European Parliament should be able to take such decisions, if the full involvement of the EP, in whichever way, is deemed to be desirable: all MEPs or only those from the Member States participating in the Eurozone? If the European Parliament is to compensate for the lack of parliamentary legislative and budgetary powers at national level (in some EU Member States at least), its competences would need to be drastically extended to this effect. ${ }^{26}$ This would mean that the EP would take part in decisions regarding, for example, the European Semester (ES), the Excessive Deficit Procedure (EDP), the Macroeconomic Imbalance Procedure (EIP) and the multilateral surveillance.

Under the current Treaties, the European Parliament is only involved in the ordinary legislative procedure in accordance with Article 121(6) TFEU on the procedural aspects of the multilateral surveillance procedure, Article 129(3) TFEU for amending certain provisions of the European System of Central Banks (ESCB) and the European Central Bank (ECB) Statute and Article 133 TFEU regarding the currency law. ${ }^{27}$ Outside of those articles, the EP only has a consultation right or a right to information or no rights all. ${ }^{28}$ And while the Treaties expressly provide for a differentiation of Council voting rights depending on whether or not a Member State is part of the Eurozone or not, such a differentiation is not made with regard to MEPs. ${ }^{29}$ Article 20(3) TEU on enhanced cooperation, for example, states that while all members of the Council may participate in the deliberations, it is only those members representing a Member State participating in the enhanced cooperation that have a right to vote thereon. Concerning the EMU, Articles 136(2), 138(3), 139(4) and 140(2) TFEU also make a distinction between Council members from EurozoneMember States and those from non-Eurozone Member State by expressly stating that "only members of the Council representing Member States whose currency is the euro shall take part in the vote." Such a differentiation is not made for the European Parliament. ${ }^{30}$

A possible problem with the full involvement of the entire European Parliament in Eurozone matters is that it might lead to a situation in which MEPs from non-Eurozone Member States could block a measure, which does not affect their own country and for

26 C. Hefftler, W. Wessels, “The Democratic Legitimacy of the EU's Economic Governance and National Parliaments”, IAI Working Papers 13|13 - April 2013, p. 3.

27 A. Maurer, "From EMU to DEMU: The Democratic Legitimacy of the EU and the European Parliament", (2013) IAI Working Papers 13|11, p. 5.

28 Ibid.

29 Ibid., p. 6.

30 Ibid. 
which the Eurozone-MEPs have voted in favour of. ${ }^{31}$ But more generally, it should also be questioned whether the Community method under the ordinary legislative procedure, involving the European Commission, the Council and the EP, is the right way forward. While, theoretically, the European Parliament represents the EU citizenry at EU level, the existence of such a citizenry is still very much disputed. Especially when one takes into account the varying degrees of differentiation between the Member States - not only between Eurozone and non-Eurozone Member States, but also considering intergovernmental treaties, Schengen or enhanced cooperation - the question must be asked as to what it means to represent all EU citizens, whom are all subject to very different measures depending on the participation of their Member State therein. In the following sections, different ways of strengthening the role of the European Parliament in the EMU will be discussed as well as the question of whether or not such a strengthened EP should act according to the principle of differentiation or not.

\subsubsection{Equalization of the European Parliament with the Council}

One way to strengthen the competences of the European Parliament in EMU matters would be to assimilate it to the Council by subjecting the decision-making process of the latter to the ordinary legislative procedure and thus in the hands of the European Parliament and the Council together. ${ }^{32}$ In general, the EP is of the opinion that all decisions taken within the framework of the EMU should be Treaty-based as "any departure from the Community method and increased use of intergovernmental agreements would divide and weaken the Union, including the euro area." 33 The idea behind this proposal is that the European Parliament is the representative organ of all citizens in the EU. If it were to be able to take binding decisions on all EMU matters, it could counterbalance the asymmetry that has arisen in the representation of the citizens by their respective national parliaments, which was discussed extensively in the previous chapters. If EU citizens no longer have to rely on their national parliaments to represent their views in EMU matters because, as it currently stands, the EP does not have full decision-making powers in that regard, democracy could be argued to be no longer be divided.

As was mentioned above, under the current Treaties, the European Parliament is only involved under the ordinary legislative procedure under Article 121(6) TFEU on the procedural aspects of the multilateral surveillance procedure, Article 129(3) TFEU for amending certain provisions of the European System of Central Banks (ESCB) and the

31 J.C. Piris, The Future of Europe - Towards a Two-Speed EU?, Cambridge University Press: United Kingdom, 2011, p. 127.

32 Maurer, supra note 27, p. 7.

33 European Parliament, Resolution of 20 November 2012 with recommendations to the Commission on the report of the Presidents of the European Council, the European Commission, the European Central Bank and the Eurogroup "Towards a genuine Economic and Monetary Union" (2012/2151(INI)). 
European Central Bank (ECB) Statute and Article 133 TFEU regarding the currency law. ${ }^{34}$ Outside of those articles, the EP only has either a consultation right or a right to information or no rights at all. This does not mean, however, that the EP has no influence on EMU measures. Out of the different measures adopted in response to the crisis, four regulations of the Six-Pack and the two regulations of the Two-Pack were adopted on the basis of Article 121(6) TFEU, partially in conjunction with Article $136 \mathrm{TFEU},{ }^{35}$ and thus through the ordinary legislative procedure, in which the EP participates as a co-legislator.

The involvement of the European Parliament as a co-legislator in the adoption of these regulations has led - through the EP's amendments to the original Commission proposal - to the insertion of the so-called Economic Dialogue (ED) into the regulations, thereby giving the EP a formal role in the European Semester that was absent from the Commission's draft. ${ }^{36}$ Before the Six-Pack, during the 2011 Semester cycle, the EP was simply meant to hold internal debates on the Annual Growth Survey between February and March and to be informed of all recommendations made by the other institutions at the end of the Semester.

The Economic Dialogue, on the other hand, provides for the (limited) involvement of the European Parliament at any time during the European Semester up until the final endorsement of the Country-Specific Recommendations (CSRs) by the European Council in July. It gives the competent committee of the European Parliament the right to invite the President of the Council, the Commission, the European Council or the Eurogroup to discuss documents and procedures relating to the European Semester (e.g., Article 1(4) of Regulation 1175/2011, Article 3 of Regulation 1173/2011, Article 14 of Regulation 1176/2011). This includes information provided by the Council on the Broad Economic Policy Guidelines (BEPG) pursuant to Article 121(1) TFEU, general guidance to Member States issued by the Commission at the beginning of the annual cycle surveillance, any conclusions made by the European Council on orientations for economic policies in the context of the European Semester, the results of multilateral surveillance carried out under this Regulation, any conclusions drawn by the European Council on the orientations for and results of multilateral surveillance, any review of the conduct of multilateral surveillance at the end of the European Semester, Council recommendations addressed to Member States in accordance with Article 121(4) TFEU in the event of significant deviation and

34 Maurer, supra note 27, p. 5.

35 Regulation 1175/2011 on improving budgetary positions and economic policies, Regulation 1173/2011 on enforcing euro area budgetary surveillance, Regulation 1176/2011 on macroeconomic imbalances, Regulation $1174 / 2011$ on correcting excessive imbalances, Regulation 473/2013 on common provisions for draft budgetary plans and excessive deficit correction, and Regulation 472/2013 on surveillance for Member States with financial difficulties.

36 C. Fasone, "European Economic Governance and Parliamentary Representation. What Place for the European Parliament?”, (2014) 20 European Law Journal, p. 171. 
the report made by the Council to the European Council (Article 1(4) of Regulation 1175/2011 amending Regulation 1466/97).

The involvement of the European Parliament in the adoption of these regulations has also led to a better position for itself under the latter. An argument can be made that this might also be the case if other legislative acts regarding the economic governance of the EU were to be adopted pursuant to the ordinary legislative procedure. Ensuring the participation of the European Parliament in the adoption of legislative acts in EMU matters would consequently lead to a stronger position for the EP under these acts themselves, as the EP can be assumed to push for a strengthening of its position during the negotiations, as it did with regards to the Six-Pack.

Thus, involving the European Parliament in the decision-making process of the EMU through the ordinary legislative procedure not only ensures that the representative organ of the EU takes part in the latter - which in itself can be a desirable aim from a democratic perspective - but it could potentially also lead to a stronger position for the EP under the economic governance framework that is to be adopted as a whole. This would include not only Treaty-based measures in which the EP is a co-legislator, but also international agreements such as the ESM. In its resolution of 20 November 2012, the EP itself stated that the ESM "should evolve towards Community-method management and be made accountable to the European Parliament" by making "[k]ey decisions, such as the granting of financial assistance to a Member State and the conclusion of memorandums [...] subject to proper scrutiny by the European Parliament." ${ }^{37}$ The resolution also calls for a right for the EP to hear and scrutinize the Troika, which is responsible for monitoring the implementation of the obligations set forth in the Memoranda of Understanding under the ESM.

\subsubsection{Stronger involvement of the European Parliament in the European Semester}

Other ways to involve the European Parliament as a whole in EMU matters could be to ensure its participation in all stages of the European Semester. The European Parliaments does not, for example, have any powers that reach beyond debating and discussing European Semester issues. It does not have any binding or consultative powers within the Semester. Thus, one way to strengthen the parliamentary component of the European Semester and thereby increase its democratic credentials could be to give the European Parliament the right to discuss and consent to the Country-Specific Recommendations as well. Under the current framework, the CSRs are drafted by the Commission, discussed by the Council and endorsed by the European Council. Neither the European Parliament nor the national parliaments have an active role in influencing these recommendations after they have been

37 European Parliament Resolution, supra note 33. 
proposed by the Commission, even though the latter are later expected to incorporate them in their budgets.

The European Parliament, under the current framework, also lacks a role in imposing sanctions on Member States under both the Excessive Deficit Procedure and the Macroeconomic Imbalance Procedure (MIP). Instead, under both procedures the decision to impose sanctions is taken by the Council, following a proposal of the European Commission, by reverse qualified majority voting. As was explained in Chapter 6, the introduction of the RQMV procedure significantly strengthened the position of the Commission, whose decisions become semi-automatic under the procedure as they are deemed to be adopted unless rejected by the Council by a qualified majority. Because sanctions can ultimately include a fine of $0.2 \%$ to $0.5 \%$ of GDP - this form of sanction is actually required for Euro area Member States under the EDP - it heavily impacts the Member State concerned. The switch from the normal QMV procedure to the reversed qualified majority voting procedure was intended to detach the decision from political considerations in the Council, which in the past have often proven to be an issue when it comes to imposing sanctions on noncomplying Member States. At the same time, it put a lot of power into the hands of the Commission, whose decisions are now more easily enforceable but remain without a democratic counterbalance in the European Semester.

This situation could be rectified by giving the European Parliament, for example, a right to consent when it comes to sanctioning Member States under both the EDP and the MIP. In its 2012 resolution, the European Parliament called for an interinstitutional agreement to involve itself in the drafting and approval of the Annual Growth Survey (AGS) and the Broad Economic Policy Guidelines and Employment Guidelines, which form the basis of the European Semester. ${ }^{38}$ The resolution suggested a right for the President of the EP to speak at the European Spring Council regarding the Parliament's view on the AGS. A stronger involvement of the European Parliament in the European Semester could give more legitimacy to the decisions that are made thereunder. Similar to the argument made in relation to its equalization with the Council in EMU matters, if it were to have a say in the decision to impose sanctions on Member States or if it were given wider scrutiny powers vis-à-vis the other actors in the decision to impose sanctions, it could make such decisions more democratic by involving the institution that represents the interests of citizens in the EU, especially in light of the asymmetries that exist between national parliaments in EU affairs. 


\subsubsection{Stronger scrutiny powers $v i s-\grave{a}$ - $v i s$ a newly established EU Minister of Finance}

Another idea, which was put forward by Commissioner Moscovici, ${ }^{39}$ is to merge the offices of the Commissioner responsible for the Economic and Monetary Union and the President of the Eurogroup into a single EU finance minister, who would be fully accountable to the European Parliament as a whole. The European Parliament would be involved in his or her appointment as well as retain normal scrutiny powers vis-à-vis such a position. ${ }^{40}$ An EU finance minister could, at the same time, also be in charge of economic policy coordination in the EU. Alternatively, and without changing the current structure of the different decision-making institutions, the presidents of the Eurogroup and the Euro summit respectively could both be made accountable to the EP. This would include a right to information for the EP with regard to the ECOFIN and Eurogroup meetings, including the transmission of "key internal documents, agendas and background material in advance of their meetings" to the European Parliament. ${ }^{41}$ In addition, both presidents could be obliged to regularly appear before the European Parliament for questioning and, conversely, the President of the European Parliament could participate in European Council and Euro Summit meetings.

This proposal could counterbalance the problem of the disrupted and asymmetric chain of accountability between the different national governments and their electorates at home as was described in previous chapters by providing for a clear accountability mechanism at EU level. By providing the European Parliament with stronger scrutiny powers vis-à-vis specific actors that have the decision-making power on EMU matters, or that at least can speak for the collective body that does, the chain of accountability between the citizens and those taking the decisions could, to some extent, be re-established, albeit not at the national level but on the European level.

\subsubsection{Differentiated European Parliament}

If the position of the European Parliament were to be strengthened within the EMU, the question arises as to how decisions that only concern the Eurozone should be treated within the European Parliament itself. Should all MEPs be able to vote on Eurozone matters or should only MEPs from those Member States who participate in the Eurozone be able to do so? The former option would result in a situation whereby MEPs from non-participating Member States could veto measures that are not applicable to them against the will of MEPs from participating Member States to whom such decisions would apply. A solution

39 European Commissioner Moscovici, Remarks on the Deepening of Europe's Economic and Monetary Union, available at: <http://europa.eu/rapid/press-release_SPEECH-17-1479_en.htm > (last retrieved on 31 October 2017).

40 European Parliament Resolution, supra note 33.

41 Ibid. 
to this issue could be a differentiated role for the European Parliament. ${ }^{42}$ This would mean limiting voting rights pertaining to a certain measure to only those MEPs that are from Member States that are, in fact, affected by the measure to be adopted, meaning that for example only MEPs from Eurozone Member States could vote on Eurozone matters. This problem does not, however, only concern Eurozone matters. Thus, also outside the Euro/non-Euro divide there are a variety of areas in which the EP takes decisions, which do not apply to all 28 EU Member States, for example where it concerns fisheries. ${ }^{43}$ The advantage of using the European Parliament in a differentiated manner would be that one could rely on an already existing institution, as opposed to having to create a new one (see Section 7.3.2).

However, the most obvious argument against this proposal is that the differentiation of the EP according to nationality would run counter to the spirit of the Treaties: the EP has a European mandate, not a national one. ${ }^{44}$ Article 10(2) TEU stipulates that the EP directly represents EU citizens as a whole and does not function on a nationality basis. This is also reflected by the fact that MEPs are organized and work according to denationalized political groups within the Parliament, and do not represent national interests. ${ }^{45}$ Article 20(2) TFEU provides for the right of all EU citizens

to vote and to stand as candidates in elections to the European Parliament and in municipal elections in their Member State of residence, under the same conditions as nationals of that State.

As a consequence, making a differentiation between MEPs from Eurozone Member States and non-Eurozone Member States can also be problematic in the light of the fact that nonEurozone nationals can be elected as MEPs in a Eurozone Member State according to Article 20 TFEU, ${ }^{46}$ albeit not drastically so. In this regard it could be argued that the fact that an MEP was elected by the citizens of a Eurozone Member State (and thus representing Eurozone interests) is more important than the fact that they themselves are a national of a Eurozone country.

Another argument against the differentiation of the EP is that the Euro was designed as a currency for the European Union as a whole; all Member States except for the United

42 Proposed, inter alia, by the President of European Council, the German government, and the Future of Europe Group.

43 Piris, supra note 31, pp. 128-129.

44 Ibid.

45 Maurer, supra note 27, p. 9.

46 Ibid. 
Kingdom and Denmark (and Sweden) ${ }^{47}$ are supposed to join the third stage of the EMU and adopt the common currency as soon as they meet the criteria that are laid down in Article 140 TFEU. $^{48}$ It could thus be argued that all decisions taken with regards to the Eurozone should be regarded as being a Union interest rather than a Eurozone interest alone, as they will at some point affect nearly all Member States. ${ }^{49}$ However, at the same time a counter-argument is that while it is true that all most non-Eurozone Member States will have to join the Eurozone in the future, this does not mean that they should be able to veto decisions on such matters before they have in fact adopted the Euro. Once their Member State had joined the Eurozone, they would be able to vote on Eurozone matters but there would be no reason to include them in such decision-making procedures before they join the Eurozone. Moreover, just because non-Eurozone MEPs cannot vote on certain measures, this does not preclude them from deliberating on these issues and being involved in the discussions leading up to the vote. ${ }^{50}$

One way to circumvent the stipulation in the Treaty, namely that the European Parliament represents the EU citizens as a whole, while still ensuring the (deeper) participation of MEPs from the Eurozone Member States in Eurozone matters was put forward by German MP Manuel Sarrazin. ${ }^{51}$ Instead of creating a separate parliamentary organ for the Eurozone, he suggested creating a separate Eurozone-committee within the European Parliament itself, which would be given the competence to take decisions on Eurozone matters on behalf of the EP plenary. ${ }^{52}$ By ensuring that the members of the committee would only comprise MEPs from the Eurozone countries, while at the same time ensuring a reflection of the political parties of the overall plenary, the problem of non-Eurozone MEPs voting on Eurozone matters could be removed as a result. The advantage of creating a committee within the European Parliament itself is that it would not require a Treaty change; rather the European Parliament could change its Rules of Procedures so as to allow for the establishment of such a committee and to decide on its composition. ${ }^{53}$

In summary, within the concept of strengthening the role of the European Parliament in EMU affairs, a differentiation of its MEPs is not desirable as it runs contrary to the spirit of the Treaties with regards to both the function of the European Parliament itself and the

47 Sweden does not have legal opt-out, but after the rejection of the Euro in the 2003, it has chosen not to join the Eurozone through an abnormal mathematical formula, through which it consistently does not meet the criteria.

48 The TFEU refers to non-Eurozone Member States as 'Member States with a derogation', which is supposed to be abrogated when they fulfil the conditions to join the Eurozone.

49 Maurer, supra note 27, p. 9.

50 S. Verhelst, "The Sense and Nonsense of Eurozone Level Democracy", (2014) Egmont Paper 70, p. 7.

51 M. Sarrazin website, The Case for Democratic Economic Governance in the EU-27, available at: $<$ https://manuelsarrazin.de/2012/11/08/case-democratic-economic-governance-eu-27> (last retrieved on 31 March 2017).

52 Maurer, supra note 27, p. 10.

53 Ibid. 
design of the Euro as the currency for the entire European Union. In contrast, the creation of a standing committee consisting of only Eurozone members seems to be a far more suitable solution in this regard. The integrity of the European Parliament's mandate, as is stipulated in the Treaties, would be kept intact, while still allowing for a separate decisionmaking channel for Eurozone Member States where the Eurozone is concerned. The committee would not even have to go as far as being competent to take decisions on behalf of the plenary; if it so desires, the committee could simply express the wishes of its (Eurozone) members by means of a resolution, which the plenary in turn would promise to use as a basis for its own decisions. It is, however, debatable whether strengthening of the European Parliament in EMU affairs is in fact that way in which the EU should move forward in order to solve the problem of representative democracy.

\subsubsection{Shortcomings in the representativeness of the European Parliament}

While making use of the European Parliament - which after all is the representative organ of the EU - to compensate for the divergent levels of democracy in the different Member States is tempting because it would simply mean extending competences that already exist into a small number of further areas, there are also certain shortcomings to this solution. The most obvious problem, i.e. that a Treaty amendment would be required to change the legislative procedure for matters falling under the scope of the EMU, could be solved through inter-institutional agreements, under which the Council and the Commission vow to take the EP's views and amendments into consideration in the decision-making process, as if the latter were taken in accordance with the ordinary legislative procedure. Similarly, the EP's participation in the European Semester could be solved by inter-institutional agreements or an amendment to the Six- and Two-Pack legislations.

A more pressing problem, however, is the question as to whether the European Parliament, as an institution, is a suitable body to make up for the lack of democratic representation of some national parliaments or whether the EP itself lacks the necessary representative credentials to do so. As was already mentioned in the introduction to this book, the challenge that the EP faces is that it is often not considered by EU citizens as a representative organ that is on par with their parliaments at home. European Parliament elections are often treated as second-order elections - less important than national elections and with a consistently lower turnout - because the EP is not believed to be able to make an impact for the citizens through the representation of their interests. This is moreover a problem due to the way that the European Parliament is elected. Because it is elected based on the principle of degressive proportionality, it is not guaranteed that a majority decision taken in the EP will necessarily reflect the wishes of the majority of Union citizens. Hence, even if the European Parliament were to be fully equalized with the Council and strengthened with regard to its scrutiny powers in EMU matters, this would not automatically lead to a more equal representation of all citizens in such matters. 
In fact, the argument could be made that strengthening the European Parliament does not actually solve the problem at all. EU representative democracy would still be based on two dual strands, namely representation through the European Parliament and representation through the national parliaments. While the first strand would be reinforced to a considerable extent, this would not actually have an impact on the second strand. Citizens from different Member States would still be represented differently at EU level by their national parliaments and the feeling of being dominated by another Member State's parliament cannot be removed simply by increasing the powers of the European Parliament. It might mitigate the impact of the asymmetry between the national parliaments in relation to representative democracy by providing stronger pan-European representation, but it cannot replace the role that the national parliaments play for the citizens of the Member States.

This is also where the problem of the lacking demos in the EU re-emerges. As was discussed in Chapter 2, the delegation of authority to an elected representative also presupposes the existence of a single people, a demos, which have the same holistic interests and which is therefore capable of undertaking the act of delegation. Such a single demos does not exist in the EU, but rather several demoi exist concurrently in the different Member States. Considering the concept of representative democracy that was defined in Chapter 2, it is difficult to reconcile the notion of representation with the existence of such a variety of citizenries in the EU. Therefore, the European Parliament might be able to mitigate the problems for representative democracy that result from the asymmetries between national parliaments of the Member States, but it is not able to fully compensate for it, nor will it be able to fully compensate for it until there is something such as a European demos in the EU.

\subsubsection{Separate parliamentary assembly for the Eurozone}

Instead of strengthening the existent parliamentary chamber at EU level - the European Parliament -, another idea is to create a separate parliamentary assembly for the Eurozone altogether, i.e., a Euro-Chamber or Euro-Parliament. This idea was most prominently put forward by French President Macron at regular intervals during 2017, as a means to improve democracy in the Eurozone. Both ideas of creating either a Euro-Chamber of a Euro-Parliament go in a similar direction of establishing a smaller representative assembly for the Eurozone Member States only. While a Euro-Chamber, as it was proposed by former German Foreign Minister Joschka Fischer, would be composed of MPs from the national parliaments, ${ }^{54}$ a Euro-Parliament would consist of both MEPs and MPs from national

54 Maurer, supra note 27, p. 8. 
parliaments. ${ }^{55}$ The purpose of both ideas is the same, namely for the new parliamentary organ to take part in the legislative procedure where the measures to be adopted concern the Eurozone, as well as to scrutinize decisions taken by the Commission and the Eurogroup in such matters.

The creation of a new parliament for the Eurozone, whether it consists of only national MPs or both MPs and MEPs, would have the advantage that accountability could be organized at the same level as where decisions are taken. If the new Eurozone parliament were to have wide-ranging scrutiny powers vis-à-vis the Eurogroup and the Eurosummit, or even vis-à-vis a newly created Eurozone government as has been proposed by Emmanuel Macron, the chain of accountability could be restored in this regard. This would presume, however, that the Eurozone parliament would be able to control, mandate and, in cases of divergences from its mandate, sanction the Eurozone executive. A new parliament created only for the Eurozone would have the added benefit that it does not raise the same questions as the European Parliament with regards to whether or not it is able to represent the citizens of the Eurozone Member States. For one, it does not have any members that do not come from a Eurozone Member State. Second, it would be composed of the members of the national parliaments (or at least partially), which means that its members would not be elected in the same 'second-order-elections'-manner as members of the European Parliament. This in turn would mean that citizens might feel more represented by that new parliament than by their MEPs in the European Parliament.

The downside to this idea is, however, its feasibility. Many questions remain open in the discussion of the creation of a new Eurozone parliament. For example, what is the scope of the act of creating a new parliament - would its creation be limited to the Eurozone only or would a separate parliament be required for any form of differentiated integration $?^{56}$ It can be argued that since the common currency constitutes the most far reaching measure of differentiated integration hitherto, it is only the Eurozone which is in need of a separate parliament; but the implications of such a precedence should nevertheless be kept in mind before the European Union ends up in a situation whereby it has a separate parliament for every policy area, in which not all Member States were willing to participate.

Moreover, the composition of the new Eurozone parliament is an issue that needs to be considered. Even if it were to be composed of members of the national parliaments, questions regarding the size of the parliament and the distribution of seats remain unanswered. How should seats be distributed amongst different Member States, but also between the political party groups, ${ }^{57}$ in order to make it more representative in light of the size of

55 Ibid., p. 9.

56 W. Wessels, "National Parliaments and the EP in Multi-Tier Governance: In Search for an Optimal MultiLevel Parliamentary Architecture", (2013) European Parliament Report, Challenges of Multi-Tier Governance in the European Union - Effectiveness, Efficiency and Legitimacy, Compendium of Notes, p. 104. Ibid., p. 105; Maurer, supra note 27, p. 9. 
the Eurozone Member States as well the political landscape? The number of seats accorded to each Member State must still be proportionate to their respective populations and at the same time it needs to be ensured that all political parties in the parliaments are proportionally represented - two requirements that could potentially lead to a very big parliament. ${ }^{58}$ In addition to that, members of the Eurozone parliament would have to act according to the pan-Eurozone political groupings within the parliament, irrespective of their nationality. They have to represent the Eurozone citizens as a whole as opposed to only the citizens of their own Member State, otherwise the Eurozone parliament would serve no other purpose than the Council, which represents the Member States' interests. In such a case, however, it would be very similar to the current European Parliament, or more specifically to the European Parliament that existed before the 1970s when there was still a system of dual mandates in operation.

Moreover, it is questionable whether the creation of yet another EU institution would, in fact, contribute to mitigating the democratic challenges in the EU from the perspective of the citizens. There is currently an array of different institutions, with the Eurogroup and Euro summit recently coming to the fore as additional configurations, which makes it difficult to oversee for the average European, who is moreover already represented by a variety of parliamentary assemblies at European, national and regional level. It is doubtful that an EU citizen would feel adequately represented by yet another parliamentary organ, which would only make the decision-making structure of the EU more complicated. Overall, the creation of a Eurozone parliament, even though a good idea at first sight, raises more questions and issues than it solves. Depending on its design, it either serves the same purpose as the Council, except that it would be more directly elected than the representatives in the former, or the same purpose as the European Parliament, but with a composition scheme that existed over forty years ago.

\subsubsection{Strengthening the national parliaments through interparliamentary cooperation}

Another, and in this book the last discussed, option that could be used to increase parliamentary involvement and scrutiny in EMU matters is the strengthening of the role of national parliaments therein through stronger interparliamentary cooperation. In contrast to the previous proposals, which aim at strengthening parliamentary involvement in the EMU at the European level, such a proposal starts from the premise that

[ $\mathrm{t}$ ] hanks to their intrinsic prerogatives in the budgetary field and their politicolegal proximity to the taxpayer, NPs, even more so than the European Parlia-

58 Wessels, supra note 56, p. 105. 
ment (EP), have the authority to tackle the crisis and therewith endow the EU with a representative dimension it could not otherwise garner. ${ }^{59}$

In accordance with this view, which links to the previous discussion on the representativeness of the European Parliament in this book, attempts to improve the state of representative democracy in the European Union should not be accomplished at the European level but rather at the national parliamentary level. This could be done by strengthening interparliamentary cooperation in the EU.

Interparliamentary cooperation has during the last decades developed into an integral part of parliamentary activities in the EU. Thus, Article 12 TEU states that national parliaments "contribute actively to the good functioning of the Union [...] by taking part in the interparliamentary cooperation between national Parliaments and with the European Parliament." Together with the European Parliament, national parliaments contribute to the democratic legitimization of the European Union through different means, which to some extent also requires cooperation and coordination amongst them, if their actions were to have any meaningful effect. Under the Early Warning Mechanism (EWM), which is laid down in Protocol $\mathrm{No}^{\circ} 2$ on the application of the principles of subsidiarity and proportionality, a certain degree of collectivity is necessary in order for the national parliaments to have a meaningful impact on democratic legitimacy ${ }^{60}$ It requires at least one third of the overall number of votes allocated to the national parliamentary chambers in order to trigger the yellow card procedure. This means that one single national parliament or one single national parliamentary chamber has very little influence, if it is not joined by other parliaments or parliamentary chambers in issuing a reasoned opinion on the same legislative proposal. The general idea is that the democratic legitimization provided by national parliaments can be enhanced through cooperation between them as well as between them and the European Parliament. ${ }^{61}$

According to the Guidelines for Interparliamentary Cooperation in the European Union, which was adopted by the Conference of Speakers of the European Union Parliaments in 2008, ${ }^{62}$ the objectives of interparliamentary cooperation are three-fold: first, it serves to "promote the exchange of information and best practices between the national parliaments of the European Parliament with a view to reinforcing parliamentary control, influence and scrutiny at all levels." Secondly, it ensures the "effective exercise of parlia-

59 D. Jancic, "National Parliaments and EU Fiscal Integration", (2016) 22 European Law Journal, p. 227.

60 V. Knutelska, "Cooperation among National Parliaments: An Effective Contribution to EU Legitimation?", in B. Crum and J.E. Fossum (eds.), Practices of Interparliamentary Coordination in International Politics, the European Union and Beyond, ECPR Press: United Kingdom, 2013, p. 35.

61 This idea was advanced by Crum's and Fossum's idea of a multilevel parliamentary field.

62 Conference of Speakers of the European Union Parliaments, Guidelines for Inter-Parliamentary Cooperation in the European Union (2008), available at: <www.ipex.eu/IPEXL-WEB/euspeakers/getspeakers.do> (last retrieved on 31 October 2017). 
mentary competences in EU matters in particular in the area of monitoring the principles of subsidiarity and proportionality" and thirdly, it promotes the cooperation with third country parliaments. ${ }^{63}$

The following part will describe the different forms of interparliamentary cooperation as to how it has developed in the EU in the past as well as of what the advantages and shortcomings of it are. It will then make a recommendation in this regard for the future of parliamentary participation in EU affairs. The focus will be particularly on the two main formalized formats thereof, i.e., the Conference of Speakers and COSAC as well as the newly established Article 13 Conference dealing with EMU matters, as examples as to how interparliamentary cooperation could be modeled or strengthened in the future in the EMU.

\subsubsection{Conference of Speakers of the European Union Parliaments}

The Conference of Speakers of the European Union Parliaments, which finds its legal basis in Article 9 of Protocol $\mathrm{No}^{\circ} 1$, gathers together the speakers of the national parliaments of the Member States and the President of the European Parliament. The Conference is responsible for overseeing the coordination of interparliamentary activities in the EU as a whole. It meets every year to debate issues concerning EU integration and parliamentary scrutiny. ${ }^{64}$ General discussion points, since 2009 at least, often include questions pertaining to the role of national parliaments and interparliamentary cooperation in the EU in general, such as the implementation of the Treaty of Lisbon, issues with IPEX, the development of the Political Dialogue with the European Commission, subsidiarity checks by national parliaments and the parliamentary dimension of the next Council Presidency. Other key points of the agenda of the Speakers' Conference are more linked to current European issues at that time.

Between 2009 and 2012, the then on-going economic and financial crisis was debated at every meeting, for example, with a particular focus on the role of national parliaments therein. Thus, during the Speakers' Conference in May 2010 in Sweden, the agenda specifically asked the question of whether or not national parliamentary budgetary powers were affected by the crisis and how national parliaments have dealt with possible cut-backs to their respective budgets. During the meeting in April 2011 in Brussels, the speakers debated the role of national parliaments and interparliamentary cooperation in the field of economic governance and in the European Semester, while in April 2012 the focus was more on the newly signed Treaty on Stability, Coordination and Governance in the EMU. In 2011 (Brussels) and 2012 (Warsaw), public opinion and the media were discussed as

63 Ibid., p. 3.

64 D. Jancic, "Representative Democracy Across Levels? National Parliaments and EU Constitutionalism", (2012) 8 Croatian Yearbook of European Law and Policy, p. 242. 
well as the role of national parliaments in the AFSJ, while during the Speakers' Conferences in April 2013 (Cyprus) and April 2014 (Lithuania) the attention shifted towards the problems in the Mediterranean region - including the role of EU parliaments in enhancing democracy and human rights in that area - and the role of national parliaments in the aftermath of the crisis and during times of austerity. In 2016 (Luxembourg) and 2017 (Slovakia), questions of how to manage the migration flows and ensure the security of citizens while simultaneously respecting fundamental freedoms were discussed, as well as the future of the EU and the parliamentary agenda in a globalized world.

As this constitutes the form of interparliamentary cooperation that is responsible for coordinating and overseeing all other forms of communication, the Conference of Speakers also took the decision to create the Interparliamentary Conference for the Common Foreign and Security Policy (CFSP) and the Common Security and Defence Policy (CSDP) during the April 2011 meeting in Brussels. ${ }^{65}$ In particular, the European Parliament has, in the past, defended and enforced the role of the Conference of Speakers as the "the pre-eminent interparliamentary body in the EU, with a role as the organizer and supervisor of other forms of interparliamentary cooperation", and has been hesitant to allow COSAC to take over this role. ${ }^{66}$ This became especially clear during the debates on the establishment of the Article 13 Fiscal Compact Conference, as will be discussed below.

\subsubsection{COSAC (Conference of European Affairs Committees)}

The most well-known form of interparliamentary cooperation is the Conference of European Affairs Committee, also known as COSAC. The purpose of COSAC is to enable (the European Affairs Committees of) national parliaments and the European Parliament to regularly exchange information, best practices and views on EU activities and to thereby, amongst others, narrow the information gap that exists between parliament and government at national level. It was established in 1989 by the Conference of Speakers and meets twice a year, ${ }^{67}$ usually in the parliament of the Member State that holds the Presidency of the Council. The delegations consist of six members of each national parliament as well as six members of the European Parliament. ${ }^{68}$

COSAC was formally recognized in a Protocol that was attached to the Treaty of Amsterdam in 1997 and as of then it has had the power to put forward non-binding contributions to the EU institutions on legislative proposals or initiatives, especially those concerning the Area of Freedom, Security and Justice, the principle of subsidiarity and

\footnotetext{
65 Ibid.

66 I. Cooper, “The Emerging Order of Interparliamentary Cooperation in the Post-Lisbon EU”, in D. Jancic (ed.), National Parliaments after the Lisbon Treaty and the Euro Crisis - Resilience or Resignation?, Oxford University Press: United Kingdom, 2017, p. 242.

67 Knutelska, supra note 60, p. 37.

68 Jancic, supra note 64, p. 246.
} 
fundamental rights. ${ }^{69}$ Since the entry into force of the Treaty of Lisbon, Article 10 of Protocol $\mathrm{No}^{\circ} 1$ states that COSAC

may submit any contribution it deems appropriate for the attention of the European Parliament, the Council and the Commission. [...] It may also organize interparliamentary conferences on specific topics, in particular to debate matters of common foreign and security policy, including common security and defence policy.

Such contributions, however, are not binding on the national parliaments and do not prejudice their positions. Hitherto, COSAC remains the most formalized form of interparliamentary cooperation and the only body with a Treaty-enshrined possibility to send its findings to the other institutions. ${ }^{70}$

Along with bringing the European Affairs Committees of the different national parliaments together, COSAC has, over the years, also acquired a coordinating role when it comes to national parliamentary activities. Thus, for example, before the entry into force of the Treaty of Lisbon, which formally introduced the possibility for national parliaments to carry our subsidiarity checks and to object to legislative proposals on subsidiarity grounds, if a sufficient number of chambers send in a so-called reasoned opinion under the Early Warning Mechanism, ${ }^{71}$ COSAC carried out eight subsidiarity tests to put the EWM to a practical test. ${ }^{72}$ National parliaments were asked to check legislative proposals and to send those proposals, on which they had subsidiarity concerns, to COSAC. COSAC in turn selected a number of proposals, which were then collectively checked by all the participating national parliamentary chambers - 31 out of 37 in 2005 and 27 out of 37 in 2006 for example - on the grounds of subsidiarity. ${ }^{73}$ This active role played by COSAC with regard to subsidiarity checks stopped after the entry into force of the Treaty of Lisbon. While parliamentary chambers in Slovenia, the Czech Republic, Slovakia, Poland, France and Germany supported such a coordination of parliamentary action under the EWM, the chambers in Austria, Finland, Sweden, the UK, Ireland and Denmark were of the opinion that national parliaments should carry out their own subsidiarity checks. ${ }^{74}$ Never-

69 Ibid.

70 D. Fromage, "Increasing Inter-Parliamentary Cooperation in the European Union: Current Trends and Challenges”, (2016) 22 European Public Law, p. 753.

71 Protocols $\mathrm{No}^{\circ} 1$ and 2 to the Treaty of Lisbon.

72 C. Neuhold, "Late Wake-Up Call or Early Warning? Parliamentary Participation and Cooperation in Light of the Treaty of Lisbon", Paper prepared for the UACES Conference: The Lisbon Treaty Evaluated: Impact and Consequences, London, 31 January - 1 February 2011, p. 7.

73 Ibid., pp. 7-8.

74 Ibid. 
theless, the possibility for coordinated checks on a more ad hoc basis based on each Presidency's preferences was not entirely ruled out. ${ }^{75}$

Generally speaking, the nature and content of COSAC meetings is very dependent on the preferences of the parliament of the Member State that holds the Council Presidency. While some parliaments prefer to organize more procedural meetings, others like to focus on more political issues; ${ }^{76}$ it is often the case that representatives of the European Commission or the Council presidency are invited to speak at COSAC meetings. ${ }^{77}$ Thus, for example, during the last LVII COSAC meeting from 28-30 May 2017 in Malta, Frans Timmerman, Vice-President of the European Commission, was invited to give a keynote speech on the role of national parliaments in the future of the EU. Other topics of that meeting included the outcome of the UK referendum - with Michel Barnier, the chief Brexit negotiator, and Danuta Maria Hüber, the chair of the Committee on Constitutional Affairs in the European Parliament, as keynote speakers -, the EU integrated maritime policy, the fight against human smuggling and trafficking and the establishment of a return and readmission policy. ${ }^{78}$

During the LVI COSAC meeting that was held under the Slovakian Presidency from 13-15 November 2016, topics included the strengthening of the role of national parliaments in the EU, TTIP, the energy union and the securing of external borders in the EU. Also here, two of the Vice-Presidents of the European Commission were invited (Timmermans and Sefcovic), along with the Prime Minister of Slovakia and the EU deputy chief negotiator on TTIP amongst others. ${ }^{79}$ The LV COSAC meeting took place from 12-14 June 2016 in the Netherlands and its main points for discussion were the exchange of best practices for parliamentary scrutiny, the protection of the rule of law in the EU, the European Court of Auditors and migration. ${ }^{80}$ The latter was also a point of discussion during the LIV COSAC

75 D. Capuano, "The role of COSAC in the Europeanisation of National Parliaments and in the Evolution of Interparliamentary Cooperation", in: N. Lupo, C. Fasone (eds.), Interparliamentary Cooperation in the Composite European Constitution, Hart Publishing: United Kingdom, 2016, p. 295.

76 Ibid., p. 294.

77 C. Hefftler, K. Gattermann, "Interparliamentary Cooperation in the European Union: Patterns, Problems and Potential", in C. Hefftler, C. Neuhold, O. Rozenberg, J. Smith (eds.), The Palgrave Handbook of National Parliaments and the European Union, Palgrave Macmillan: United Kingdom, 2015, p. 96.

78 Draft Programme LVII COSAC meeting, available at: <www.ft.dk/samling/20161/almdel/euu/bilag/568/1743910.pdf> (last retrieved on 31 October 2017).

79 Draft Programme LVI COSAC meeting, available at: <https://www.senato.it/application/xmanager/projects/leg 17/file/b 1-9\%20COSAC\%20 Chairs\%20draft $\% 20$ programme $\% 20$ EN $\% 20$ \%20update\%2001072016(1).pdf> (last retrieved on 31 October 2017).

80 Draft Programme LV COSAC meeting, available at: <https:/ghum.kuleuven.be/ggs/2016-06-meeting-ofthe-plenary-cosac-draft.pdf> (last retrieved on 31 October 2017). 
meeting in Luxembourg that was held from 29 November to 1 December 2015, as was the Digital Single Market Strategy for Europe and the EU's enlargement policy. ${ }^{81}$

Generally it can be said that, even if certain parliaments may prefer a more procedural focus during the COSAC meetings, the debates therein nevertheless often involve political topics that are contemporary European issues at the time of the meetings. ${ }^{82}$ Looking at the agendas of the COSAC meetings during the last few years, it seems that alongside the general issues of the exchange of best practices and information and the role of national parliaments in various EU sectors, almost all of the meetings also included a discussion of current topical issues. For example, the first meeting of 2017 which took place in May dealt with the issue of Brexit, after the United Kingdom had officially submitted its withdrawal letter in March of the same year. Similarly, in 2016 and 2017 during the height of the refugee crisis in the EU, all COSAC meetings dealt with migration and EU admission policies, whereas the focus in 2013 and 2014 was more on the position of Ukraine, amongst other topics. The meetings in June 2013 in Ireland and in June 2014 in Greece also dealt with the future of the EU youth after the financial crisis. The effect of the latter in general, including connecting themes like the Europe 2020 strategy, was debated in COSAC meetings from 2010 to 2014, while the meetings in October 2013 in Lithuania and in June 2014 in Greece - thus right before and after the elections of the European Parliament in June 2014 - also discussed the EP elections and the resulting new EU leadership.

It thus seems that almost all COSAC meetings "have been prepared on real, actual, European topics and taking into account requests coming from a significant number of national parliaments/chambers" ${ }^{13}$ and thus go beyond being just mere networking events that do not engage in any meaningful discussions as regards to content. In addition to the bi-annual meetings, COSAC also publishes biannual reports as well as comprehensive questionnaires on different topics of importance for EU scrutiny, including the national parliaments' replies thereto.

In general, COSAC has contributed to strengthening the position of European Affairs Committees in the national parliaments in the EU by bringing them together and giving them a special status that is autonomous from other sectoral committees and the plenary assemblies. ${ }^{84}$ The question is whether such coordination can also contribute to improving representative democracy in the EU. On the one hand, it can be argued that its objectives remain rather procedural and that it does not address the problem that the relationship

81 Draft Programme LIV COSAC meeting, available at: < https://www.senato.it/application/xmanager/projects/leg17/file/b1-9\%20POJ\%20LIV\%20COSAC\%20E\%20151125.pdf> (last retrieved on 31 October 2017).

82 Capuano, supra note 75, pp. 297-298.

83 Ibid., pp. 297-298.

84 Ibid., pp. 294. 
between the citizens and the national parliaments in EU affairs is often disrupted. ${ }^{85} \mathrm{On}$ the other hand, COSAC has developed into a more politicized body whose debates do, in fact, relate to actual and contentious European issues. In combination with the exchange of practices and information between the different national parliaments, for which it was initially created, it can also maybe be argued that while there is no direct effect of its contributions on EU policy, it does provide the national parliaments with (more) information and perspectives on current EU developments, which might be useful in their own relationships at home vis-à-vis their national governments. Such an effect could also be imagined for other forms of interparliamentary cooperation.

\subsubsection{Joint meetings on topics of common interest}

The European Parliament and the national parliament of the Member State holding the Council Presidency can also organize joint meetings on topics of common interests. The purpose of these Joint Parliamentary Meetings (JPMs) is less to come up with common positions of the parliaments, but more to strengthen parliamentary control over intergovernmental and non-legislative EU decisions. For that reason, such meetings typically focus on areas in which the EU does not have legislative competence, such as the Lisbon Strategy, the CFSP and CSDP, economic and monetary policy, enlargement or energy policy and climate change. ${ }^{86}$ According to Jancic, they mainly serve as a way for members of both the national parliaments and the European Parliament to make their positions known and to exchange information on a more informal basis, ${ }^{87}$ which is perhaps why they are more regularly organized (49 meetings between 2009 and 2013) than the meetings between sectoral committees. ${ }^{88}$

\subsubsection{Meetings of sectoral committees}

The sectoral committees of the national parliaments and the European Parliament can also meet in Interparliamentary Committee Meetings (ICM) in order to discuss EU measures that are decided under the ordinary legislative procedure (unlike the Joint Meetings on Topics of Common Interest). These meetings have as their objective the exchange of views between the national parliamentarians and the members of the European Parliament concerning concrete matters or legislative proposals, ${ }^{89}$ which might result in the possibility of the former to influence the position of the latter in the legislative process,

85 A. Cygan, “COSAC: Birth, Evolution, Failures and Perspectives”, in: N. Lupo, C. Fasone (eds.), Interparliamentary Cooperation in the Composite European Constitution, Hart Publishing: United Kingdom, 2016, pp. 207-208.

86 Jancic, supra note 64, pp. 242-243.

87 Ibid.

88 Hefftler, Gattermann, supra note 77, p. 98.

89 Jancic, supra note 64, pp. 242-243. 
in which the EP has a co-legislative role with the Council. ${ }^{90}$ Normally it is the committees of the European Parliament that organize such meetings and that invite their counterparts in the national parliaments, ${ }^{91}$ even though this does not happen all too often. ${ }^{92}$ Alongside these joint committee meetings, ad hoc committee meetings between the EP and the national parliaments can be organized by either side in Joint Committee Meetings (JCM). ${ }^{93}$

\subsubsection{Common Foreign Security Policy and Common Security and Defence Policy Conference}

As was mentioned in Section 7.3.3.1, the establishment of the Common Foreign Security Policy and Common Security and Defence Policy Conference (hereinafter: CFSP/CSDP Conference) was decided by the Conference of Speakers in $2011 .{ }^{94}$ It was the first form of interparliamentary cooperation that relates to and deals with a specific policy area. ${ }^{95}$ Article 10 of Protocol $\mathrm{No}^{\circ} 1$ identifies the CFSP and CSDP as areas on which COSAC may organize interparliamentary conferences. Nevertheless it was not COSAC, but rather the Conference of Speakers, that decided on the guidelines for the conference. The CFSP/CSDP Conference partially replaced the Parliamentary Assembly of the Western European Union (WEU) and partially replaced the bi-annual meetings of the Conference of Foreign Affairs Committee Chairpersons (COFACC) and the Conference of Defence Affairs Committee Chairpersons (CODACC) ${ }^{96}$ Since 2012, the CFSP/CSDP Conference has met twice a year and even though it is not mentioned in Article 10 of Protocol $\mathrm{No}^{\circ} 1$, its Rules of Procedures also provide for the possibility of it submitting contributions. Under its RoP, the CFSP/CSDP Conference can adopt non-binding conclusions relating to the CFSP and CSDP by consensus, ${ }^{97}$ as well the ability to invite the High Representative to appear before it. ${ }^{98}$ The presence of the latter at the CFSP/CSDP Conference, along with the foreign minister and defence minister of the Member State holding the Council Presidency, has become customary. ${ }^{99}$

\footnotetext{
$90 \quad$ Ibid., p. 242.

91 Ibid.

92 Hefftler, Gattermann, supra note 77, p. 98.

93 Jancic, supra note 64, p. 243.

94 Ibid., p. 242.

95 Cooper, supra note 66, p. 230.

96 Ibid.

97 Fromage, supra note 70, pp. 753-754.

98 Jancic, supra note 64, p. 242.

99 Cooper, supra note 66, p. 230.
} 


\subsubsection{Interparliamentary Conference on Economic Governance of the European Union}

Similar to the CFSP/CSDP Conference, the Treaty on Stability, Coordination and Governance in the Economic Monetary Union also calls for an interparliamentary conference to deal with a specific policy area, but in this case economic governance. Article 13 of the TSCG provides for the

organization and promotion of a conference of representatives of the relevant committees of the European Parliament and representatives of the relevant committees of national Parliaments in order to discuss budgetary policies and other issues covered by this [the SCG] Treaty.

Based on this article, the Interparliamentary Conference on Economic Governance of the European Union (hereinafter: the Article 13 Conference) was established in 2013 and held its first meeting in October 2013 in Vilnius. ${ }^{100}$

Like COSAC and the CFSP/CSDP Conference, the Article 13 Conference also meets twice a year. While one meeting takes place in and is hosted by the national parliament of the Member State that holds the Council Presidency, the other meeting takes place in the European Parliament and is co-hosted by the EP and by the presidency's national parliament. ${ }^{101}$ This latter meeting is organized within the framework of the European Parliamentary Week, which takes place in January each year and consists of two events: the Article 13 Conference and the European Semester Conference. The European Semester Conference provides national parliaments with the opportunity to

exchange information on best practices in implementing the Semester cycles, and to strengthen cooperation in order to scrutinize the actions of the executive at national and European levels within the framework of the European Semester cycle. $^{102}$

The reason why the European Parliamentary Week takes place in January, i.e. relatively early in the European Semester cycle, is that it gives the EP the possibility to consult with national parliaments before it holds its own debate on the Commission's Annual Growth Survey in February. ${ }^{103}$ This also implies, however, that the Conference is not intended as

100 I. Cooper, "The Politicization of Interparliamentary Relations in the EU: Constructing and Contesting the Article 13 Conference on Economic Governance”, (2016) 14 Comparative European Politics 14, p. 197.

101 Ibid., p. 204.

102 European Parliamentary Week website, available at: <www.epgenpro.europarl.europa.eu/static/relnat$\mathrm{parl} / \mathrm{en} /$ conferences/european-parliamentary-week.html> (last retrieved on 1 May 2017).

103 Cooper, supra note 100, p. 205. 
a body that makes recommendations on the European Semester to the EU institutions, but rather it is meant as a way of facilitating the consultation of the national parliaments by the European Parliament, before the latter makes its own recommendations to the other institutions. $^{104}$

During the first meeting of the Article 13 Conference, which took place from 1617 October 2013 in Vilnius, the topics that were debated, alongside the discussions on the purpose and vision of the Article 13 Conference itself, related to the creation of a framework for post-crisis economic governance in the EU, the Banking Union and financial integration in the EU and budgetary consolidation and structural reforms. In January 2014, the focus of the discussions was on addressing macroeconomic imbalances in Europe, the democratic legitimacy of economic adjustment programmes and enhanced fiscal surveillance in the EU. In September 2014, the agenda of the Article 13 Conference included issues such as re-launching investment and reducing inequalities as a path to growth, EU economic and financial governance tools, the completion of the Banking Union and the coordination of European tax policies as well as the digital economy, and it concluded with a debate on the draft Rules of Procedures of the Conference. In February 2015, the Article 13 Conference that again took place within the framework of the European Parliamentary Week dealt with the stimulation of public and private investment for growth and jobs in Europe, fiscal consolidation and structural reforms and best practices relating thereto when implementing the Fiscal Compact and the strengthening of the social dimension of the EMU. In February 2016, the national parliaments discussed their experiences with enhanced economic coordination and governance, the effects of budgetary coordination on budgetary policy and future scenarios for investments in a competitive EU. In October of the same year, the key points on the agenda included, once again, the strengthening of the social dimension of the EMU, in addition to the fight against tax evasion in the EU, the Fiscal Union and the Common Investment Programme. During the European Parliamentary Week that took place from 31 January 2017 to 1 February 2017, the participants of the Article 13 Conference shared best practices on the Fiscal Compact as part of national economic policy making and discussed ways towards a more comprehensive and coordinated social dimension in the EMU, as well as benchmarking national reforms fostering sustainable growth and jobs. Another topic discussed was the role of financial assistance programmes and the ESM and safeguarding the Euro. The Conference is thus concerned with a very wide range of topics.

One benefit of the interparliamentary conference on EMU is that its establishment prevents the emergence of " 28 unconnected, parochial parliamentary debates that would 
disregard the perspectives of other Member States" 105 on budgetary issues in the EU. This is arguably particularly important in a field that falls outside the Community method and thus outside the scope of the European Parliament's legislative powers as per the ordinary legislative procedure. Instead of using the Community method, the EMU has - especially during the Euro crisis - heavily relied on executive actions by the Eurogroup and the Euro summit as opposed to legislative action by parliaments. ${ }^{106}$

The latter might be compensated by providing a stronger oversight mechanism by national parliaments, especially in a field that is such a sensitive issue of national sovereignty and which touches upon national parliamentary (budgetary) powers to a considerable extent. Establishing an interparliamentary conference in this area provides a forum for discussions for the European Parliament and national parliaments so as to oversee executive actions therein, ${ }^{107}$ and possibly to legitimize - or at least increase debates on - the latter. ${ }^{108}$ It also serves as a compromise between the preference of the European Parliament, the Commission and the European Council for the EP as the primary democratizing institution in the EMU on the one hand, and the national parliaments' efforts to retain their budgetary powers on the other. ${ }^{109}$ Because of the high interdependence of the economic policies of the Member States, it is advantageous to have a network for national parliaments to reflect upon and discuss the EU-wide implications of their own individual budgetary processes, similar to what already happens at the executive level. ${ }^{110}$

The Article 13 Conference hence constitutes a forum where best practices can be exchanged and where the different points of views of the national parliaments regarding the EU economic governance are brought together and can also be communicated to the European Parliament. This is a step in the right direction insofar as it provides the national parliaments with the opportunity to make their opinions known and to become aware of the issues that are of relevance to the other parliaments. Such an exchange of opinions, but also of information, is beneficial to the national parliaments because it provides them with access to information that they might not have in their own home Member State. This is especially the case for weaker national parliaments with very limited information rights under their own constitutional framework. The Article 13 Conference, as other forms of interparliamentary cooperation, therefore contributes to reducing the information asymmetries between the national parliaments by strengthening the position of weaker parliaments vis-à-vis their national governments through access to more information. By

105 D. Jancic, "Parliamentary Involvement in the Economic and Monetary Union after the Euro Crisis", in: N. Lupo, C. Fasone (eds.), Interparliamentary Cooperation in the Composite European Constitution, Hart Publishing: United Kingdom, 2016, p. 200.

106 Cooper, supra note 66, p. 229.

107 Ibid., p. 236.

108 Jancic, supra note 105, p. 200.

109 Ibid.

110 Ibid. 
bringing together the national parliaments and the European Parliament, it also opens up the possibility for national parliaments to make their views known within the European Semester through the European Parliament, which in turn can use the national parliaments' support as means to substantiate its own demands.

The Article 13 Conference is composed of members of the national parliaments of all the 28 Member States as opposed to only those that have adopted the Euro or those that are contracting parties to the TSCG. The rationale behind this decision is the same reason as to why it is not deemed desirable to divide the members of the European Parliament into Eurozone MEPs and non-Eurozone MEPs: the Euro is intended as the currency for the entire European Union and, according to this view, it is irrelevant that not all Member States have adopted the Euro hitherto. In light of the discussion in Section 7.3.1.4, it could, however, also be argued that the establishment of an interparliamentary conference for only members of national parliaments from the Eurozone and of the European Parliament can offer benefits, as it would lend the discussions a specific focus on Eurozone decisions and, in relation thereto, on the specific interests of the Member States to whom such decisions are in fact applicable. In particular the increase of decisions taken at the level of the Eurogroup and the Euro summit during the crisis could justify the creation of an interparliamentary conference of national parliaments at the same level only.

In this regard, the Article 13 Conference could serve as a role model for the creation of a new interparliamentary conference for the Eurozone. In the following, the establishment such a conference, as well as the obstacles that could arise in relation thereto, will be discussed.

\subsubsection{Establishing a new interparliamentary conference for the Eurozone}

Establishing an interparliamentary conference for the Eurozone would have a very similar purpose and advantage to the Article 13 Conference in that it would serve as a forum for the national parliaments of the Member States concerned to exchange information and best practices with regard to Eurozone matters. It would, in a similar manner, also allow national parliaments from Eurozone Member States to strengthen the coordination and cooperation between them, so as to facilitate and increase scrutiny of actions by the executive in the Eurogroup and in Euro summits. Next to the possibility for parliamentarians to learn from each other and to receive information that otherwise would not have been available to them, such a conference could furthermore facilitate the exchange of views between national parliaments, so as to allow for a mutual consideration of each other's interest when scrutinizing government actions, at least where it does not stand in conflict with the interests of their own citizens.

The reason why a new interparliamentary conference for only Eurozone Member States, alongside the Article 13 Conference, is desirable is because it would ensure that accountability could take place on the level at which decisions are taken. Because the Eurogroup 
has emerged as a strong player in the decision-making structures of the Eurozone, it should be mirrored by a structure of cooperation between the national parliaments of the same Member States. The debates within the new Eurozone conference could then also be more focused by concentrating on issues of direct relevance for the Eurozone only and, for example, exchanging information that is directly related to Eurogroup meetings in order to facilitate the ex ante and ex post scrutiny thereon.

The new conference should also include members of the European Parliament in order to reflect the intertwinement of the levels of decision-making that exist in the EMU. Even though monetary policy is conducted at EU level and despite the fact that the economic and fiscal policies of the Member States are increasingly subjected to control by the European Union, the latter still remain a national competence. Therefore, the parliamentary control exercised in these matters should also be done together at both EU and national level. ${ }^{111}$ Including the European Parliament would also constitute a compromise between opposing tendencies to retain the role of the European Parliament as the primary democratizing institution in the EU and EMU, on the one hand (see also Section 7.3.4.1), and the national parliaments' efforts to retain their budgetary powers on the other. ${ }^{112}$

Such a new interparliamentary conference for the Eurozone could also be equipped with collective decision-making powers in that it could issue binding recommendations $v i s$ - $a$-vis the Eurogroup and the Euro summit. As the latter operate on a collective basis, it can be argued that possibilities should exist to also hold them to account collectively, as opposed to leaving it to each national parliament to hold their own national representative to account individually at the domestic level.

\subsubsection{Obstacles to establishing a new interparliamentary conference}

The establishment of the Article 13 Conference, as provided for by the TSCG, did not come without disagreements and it is conceivable that the establishment of another interparliamentary conference for the Eurozone would face similar obstacles. Therefore, the following section will briefly look at the issues that arose with regards to the Article 13 Conference, when it was established.

One of the biggest issues in organizing the Article 13 Conference was the decision on its powers and scope. While the European Parliament advocated for a weak conference with a limited scope, i.e., a conference which does not have the power to take any collective decisions or to make contributions to the EU institutions and whose scope is limited solely to the implementation of the fiscal and budgetary rules of the TSCG, many national parliaments favoured a stronger conference with a broader scope, which would include the

111 V. Kreilinger, "The New Inter-Parliamentary Conference for Economic and Financial Governance”, (2013) Policy Paper Notre Europe October 2013, p. 3.

112 Ibid. 
power to take collective decisions, such as non-binding conclusions on issues, which go beyond the fiscal and budgetary areas. ${ }^{113}$ The discussions related specifically to the question of whether or not the conference should focus on the issues of the Fiscal Compact, such as fiscal consolidation and structural reforms or whether it should also include broader topics, such as the Banking Union. ${ }^{114}$ It was also the European Parliament, together with the German Bundestag, ${ }^{115}$ that opposed both the adoption of the conference's Rules of Procedures and the adoption of any conclusions by the conference. ${ }^{116}$ Similar to the EP, the German Bundestag preferred a conference that would be equipped with advisory powers only. ${ }^{117}$

But also with regard to the size of delegations, no definite agreement could be found. Many national parliaments like the Polish and Czech Senates did not want the parliaments of non-Eurozone Member States to be excluded from the conference and argued that, under the Treaties, they would have to eventually join the Euro in any case; the Visegrad Group (the Czech Republic, Hungary, Poland and Slovakia) was in favour of the participation by the national parliaments of all EU Member States, for example. ${ }^{118}$ Ultimately, the Speakers' Conference decided to include representatives from all EU national parliaments and the European Parliament, but it left it up to each parliament to decide on the size and composition of its delegations. ${ }^{119}$ An issue such as the former would not arise with regards to an interparliamentary conference for the Eurozone only, but also here a decision concerning its size and composition might face disagreements.

Another shortcoming is that not all national parliaments seem, in general, to be in support of stronger interparliamentary cooperation at the national parliamentary level. This is in particular a problem where such opposition emanates from a stronger parliament, with more access to information than its weaker counterparts, that could benefit from the former's knowledge and expertise. One of such stronger parliaments in EU affairs is the German Bundestag, as was shown in Chapter 4. In general, the German Bundestag is represented strongly in all forms of interparliamentary cooperation, ${ }^{120}$ which can also be explained by the sheer size of its members and the volume of its resources. The more members and the higher a budget a parliament has, the easier it will be for it to regularly dispatch a number of representatives to interparliamentary meetings. The Bundestag, for

113 Cooper, supra note 100, pp. 197-198.

114 Cooper, supra note 66, p. 234.

115 V. Kreilinger, "Interparliamentary Cooperation and its Challenges: The Case of Economic and Financial Governance”, in: F. Fabbrini, E. Hirsch Ballin, H. Somsen (eds.), What Form of Government for the European Union and the Eurozone?, Hart Publishing: Oxford, 2015, p. 284.

116 Ibid., pp. 210-211.

117 Ibid.

118 Cooper, supra note 100, p. 203.

119 Fromage, supra note 70, p. 754.

120 C. Hefftler, “An Ever Closer Interparliamentary Network? National Parliaments' Priorities in Interparliamentary Cooperation in the EU”, Paper for EUSA Conference, Boston, 5-7 March 2015, p. 11. 
example, can make use of the work and expertise of 3000 civil servants in its administration, including $64 \mathrm{EU}$ expert staff members, while the Irish parliament, which was considered as a contrasting parliament, can rely on the work of only about 440 civil servants for both the lower and the upper chambers of parliament - out of which only twelve focus on EU issues. Even though such differences in numbers can be explained by the difference in size of the respective parliaments, it nevertheless means that the Bundestag has more resources to devote to EU matters, including interparliamentary conferences, than the Irish Dáil.

But despite its regular attendance, members of the German Bundestag seem to appear skeptical towards formalized forms interparliamentary cooperation. ${ }^{121}$ This skepticism towards interparliamentary cooperation for a parliament such as the Bundestag could be a consequence of the fact that it already has very strong information and scrutiny rights over the German government, which were reinforced by several judgments of the German Federal Constitutional Court. It also has a relatively high number of representatives in Brussels and regularly invites rapporteurs from the European Parliament to its committee meetings so as to receive information on the negotiation process on certain proposed legislation. ${ }^{122}$ All of this would make any additional information gained through interparliamentary cooperation redundant or less important than for a parliament that does not have such resources at its disposal. In addition, stronger parliaments also tend to "maintain bilateral relations with one another instead of turning to the usual pan-European platforms" - especially in Germany, France, Finland and the Netherlands.$^{123}$

On a more general level, the German Bundestag also seems to favour a strong position of the European Parliament in the legitimizing landscape of parliaments in the EU. The relationship between the European Parliament and the national parliament, when it comes to the democratic legitimization of the EU, remains a debated question. Like the European Parliament, also the Bundestag is of the view that the EP should be the sole representative institution at Union level and that any efforts to increase EU democratic legitimacy or scrutiny of decision-making at EU level should be centralized in the European Parliament, as opposed to equipping national parliaments with such powers at EU level. Instead, NPs should stick to their role of scrutinizing their executives at national level. This was also shown by the set-up of the Article 13 Conference, which strengthens the European Parliament's position in the European Semester by giving it the opportunity to consult with the national parliaments and to use such consultation as a means of substantiating its position, but without actually including national parliaments in the European Semester process at EU level. Such skepticism vis-à-vis interparliamentary cooperation at national parliamentary

121 Ibid., pp. 16-17.

122 Ibid., p. 17.

123 B. Crum, J.E. Fossum, “Conclusion: Towards a Democratic Multilevel Parliamentary Field?”, in B. Crum, J.E. Fossum (eds.), Practices of Interparliamentary Coordination in International Politics in the European Union and Beyond, ECPR Press: 2013, p. 262. 
level could have mitigating effects on the success of a newly established interparliamentary conference for the Eurozone.

\subsubsection{Interparliamentary cooperation as the way forward?}

Interparliamentary cooperation, just as the alternatives thereto proposed in this book, has its shortcomings, not lastly because it is dependent on the willingness of parliamentarians to actively participate and exchange information and best practices. Nevertheless, it is argued here that reinforced interparliamentary cooperation might be the most suitable solution to mitigate the differences in power between national parliaments in the EU and to improve the state of representative democracy in the EU. This is not at last due to the fact that it seems unlikely that a strengthening of interparliamentary cooperation could in any case have a negative impact on the state of EU representative democracy as it currently stands. In contrast, in the best case scenario, it would facilitate national parliaments' scrutiny of executive action at EU level, inter alia, by providing them with access to information independent from the government, thereby reducing the information asymmetry, as well as revealing any shortcomings in the information provided by the government. $^{124}$

In this regard, it would in particular be beneficial to weaker national parliaments as opposed to those that are already equipped with strong information and scrutiny rights $v i s$ - $a$-vis their national governments. Not only can weaker parliaments learn from stronger parliaments through exchange of best practices, they may also use interparliamentary cooperation to gain access to information from other parliaments that would otherwise not be available to them at national level. ${ }^{125}$ Jancic states within the context of the Article 13 Conference, for example, that despite a lack of binding decision-making powers of the conference it nevertheless has an added value as it decreases the information gap between different members of parliament, which in turn can lead to more informed budgetary policy formulation. ${ }^{126}$

The distribution of information that is not available to all parliaments in the same manner has a mitigating effect on the asymmetries between them by aligning their access to information, which is one of the three instruments of parliamentary control vis-à-vis the government that were analyzed respectively in Chapters 4 and 5 of this book. While it does not change the lack of powers to issue binding mandates for parliaments, for example, as is the case in Ireland, it does facilitate the scrutiny of the government both ex ante and expost in relation to Council or European Council, or rather Eurogroup or Euro

124 Fromage, supra note 70, pp. 764-765.

125 Crum, Fossum, supra note 123, p. 260.

126 D. Jancic, supra note 59, pp. 245-246. 
summit, meetings. Such an effect is, however, dependent on the participation of those parliaments that in fact have access to the relevant information or at least access to more information than their weaker counterparts, which is why any added value of such interparliamentary cooperation would depend on the participation of stronger parliaments, which can contribute with best practices and classified government information which is not available to other parliaments.

Despite the latter qualification, it is possible that a more collective approach by national parliaments in EU affairs, whereby they can also take each other's interests into consideration when scrutinizing their own government as long as this does not stand in contradiction with their own (citizens') interest, could mitigate the differences in power that exist between them. The reason why such a consideration towards the other Member States' electorates should be taken at a national parliamentary level in the form of interparliamentary cooperation, instead of within the Council, is because the government representatives acting in the Council are bound by their national parliaments' instructions at home, either through legally binding mandates or through other means of accountability such as ex post scrutiny. This should not be underestimated as an effect on the processes and outcomes of negotiations (see Section 6.4.1.2.1). Ministers that have received a binding mandate from their national parliaments will find themselves unable to take into consideration the other governments' wishes, if such consideration would mean deviating from the parliamentary mandate. National parliaments, on the other hand, are not subject to the same constraints. They represent their citizens' interests but do not have an explicit binding mandate to achieve a specific aim. This leaves national parliaments with a higher amount of freedom and discretion to also take into consideration other points of views and to come to a more common solution than would be possible in the Council or European Council.

Such coordination of the will formation process is, in essence, similar to the view that proponents of the concept of a European demoicracy envision. European demoicracy does not understand the European Union as something similar to a federal state with one single political entity, but rather it views it as a "Union of peoples", who "govern together but not as one." ${ }^{127}$ While the understanding that there is no single demos in the EU, but rather several demoi is the same, proponents of the demoi-theory, unlike the German Federal Constitutional Court, do not arrive at the conclusion that representative democracy can only exist at nation-state level, but rather they find that such existence is not necessarily required for representative democracy - be it at the national or European level. ${ }^{128}$ Instead, they suggest that decisions and decision-making procedures should be coordinated between the various national governments, ${ }^{129}$ because national governments - even though they

127 K. Nicolaidis, “European Demoicracy and Its Crisis”, (2012) 51 Journal of Common Market Studies, p. 353.

128 Ibid.

129 F. Cheneval, F. Schimmelfennig, “The Case for Demoicracy in the European Union”, (2012) 51 Journal of Common Market Studies, p. 340. 
are under the obligation to respect each other's freedom to take decisions - must also recognize that their own (democratic) decisions may have a (negative) effect on the citizens represented by the other governments as well.

Taking this a step further, it could be argued that such recognition of the effects of one's own decisions on others should not stop at national governments, but rather that it should also extend to the national parliaments because the same argument could be applied to them. Even more so, not only could this argument also be applied to national parliaments, but it is contended that national parliaments are in fact in a better position to consider each other's interests because they are not bound by specific mandates or instructions from another institution in the same way as government representatives are. Therefore the best level to achieve a higher degree of collaboration between the Member States would be at the level of the national parliaments, because they have the most freedom to do so. This is not to mean that interparliamentary cooperation is a miracle solution for all the problems with which EU democracy is faces. It is simply contended within the framework of this book and based on the analysis of power asymmetries between national parliaments in the EU that, at this point in time and without the requirement of any Treaty amendments, increased interparliamentary cooperation could - the willingness of all national parliaments to actively participate provided - present the most optimal solution to improve representative democracy in the EU - or at least a more optimal solution than all the other scenarios described in this chapter.

\subsection{CONCLUDING REMARKS}

This chapter has suggested the different ways in which the parliamentary landscape in the EU could be re-designed in order to mitigate the negative implications for EU representative democracy that result from the described power asymmetries between national parliaments. The financial crisis in the Eurozone presented itself as a good cause to look into this particular question as the instruments adopted as a response thereto had exacerbated the power asymmetries between national parliaments in the EU and, as a result, also affected the state of representative democracy herein. There exists now a gap between the extents to which different parliaments are able to represent their citizens at EU level. Thus, citizens from a Member State with a rather weak parliament could find themselves at risk of being dominated by the decisions of another Member State with a stronger parliament. Three different proposals to remedy the impact, which the imbalance of powers between national parliaments has on EU representative democracy, have been put forward in this chapter.

The first proposal was to strengthen the role of the European Parliament through first, an equalization of its status with the Council in EMU matters; second, an increased involvement in the European Semester; and/or third, stronger scrutiny powers $v i s-\grave{a}$-vis a 
newly established EU minister of finance. It was shown that the option of doing so with a differentiated European Parliament runs contrary to the spirit of the Treaties, according to which the members of the European Parliament have a European mandate, not a national one. It also goes against the idea that the Euro is the currency for the entire Union. The problem with relying on the whole EP as an institution to compensate for the divergent levels of democracy in the different Member States, on the other hand, is that the European Parliament, first of all, faces the challenge of not necessarily being considered as representative by the citizens. But more importantly, strengthening the European Parliament would also not solve the discrepancies between the national parliaments, because the Treaties in fact provide for separate strands of representation by the EP and the national parliaments. Consequently, reinforcing one does not have an impact on the representation problems of the other, because in the same manner that the European Parliament cannot fix the national parliaments' problems on its own, strengthening the role of national parliaments would not change the EP's problem of representativeness.

The second proposal was the creation of a new Eurozone parliament, which would consist either of members of the national parliaments or of both members of national parliaments and of the European Parliament. While seemingly a good idea at first sight one that is often repeated elsewhere in the political sphere - it raises more questions than it in fact answers. The issues range from the number of its members to the distribution of seats between Member States to the distribution of seats between political parties according to the composition of parliaments at domestic level. This casts serious doubts on the feasibility of such a parliamentary assembly, if it were to have any meaningful distinction from the EP and the Council as they stand. The creation of a new parliament would also upset the carefully constructed institutional balance between the European Parliament, the European Commission, and the Council (and under certain circumstances even the national parliaments) that exists under the current Treaty framework.

The last proposal was to strengthen interparliamentary cooperation between the national parliaments and between the national parliaments and the European Parliament by establishing a new interparliamentary conference similar to the Article 13 Conference, but only for the Eurozone Member States. There are some advantages to this proposal. First of all, the basis for interparliamentary cooperation is already laid down in the Treaties, and it has been used to create a variety of forms of interparliamentary cooperation hitherto. Reinforcing interparliamentary cooperation would thus not require any Treaty amendments, nor does it run counter to any of the implicit principles laid down therein. Moreover, interparliamentary cooperation could be mutually beneficial to all actors involved. Increased cooperation between the national parliaments and between the national parliaments and the European Parliament could increase the likelihood of (all) citizens' preferences being represented at EU level. National parliaments, as the closest link to their electorates at home, could communicate the latter's interests to the European Parliament, which would 
then be able to bundle these interests and defend them at EU level. By doing so, the EP could also strengthen its own position, which it can claim to be supported by also (at least some of) the national parliaments vis-à-vis the Council and the Commission. In addition, national parliaments could benefit from the mutual exchange of information by receiving access to information independent from the government, which would otherwise not be accessible to them. The consequent reduction of information asymmetry would facilitate parliamentary exercise of scrutiny over the executive. As was discussed above, the benefits of interparliamentary cooperation seem to be in particular useful to weaker national parliaments, which on their own might not be in a position to make the preferences of their electorates heard, perhaps because either their Member State is too small and not powerful enough for their minister to be able to make a difference in the Council or because they are not able to sufficiently control their minister's actions at EU level in the first place.

This last aspect is important for this book insofar as one of the greatest problems for EU representative democracy after the crisis is that the second strand of representation, composed of the national parliaments, has been scattered to such an extent that they can be divided into first-class and second-class parliaments. By increasing the strengths of weaker parliaments in particular through a coordination of preferences and exchange of information, the trend towards different classes of parliaments could be mitigated. Thus, for example, it is imaginable that a parliament, whose country is subject to an economic adjustment programme and which has little leeway in its political maneuvers by itself, could find allies in other parliaments who in turn might be willing to influence their governments on the weak parliament's behalf when their minister takes part in EU negotiations. It is also possible to imagine that the European Parliament, especially if more than one national parliament represents the same position, would take the positions of a weaker parliament into consideration when participating in the Economic Dialogue under the European Semester, for example.

While all these scenarios are, of course, very optimistic as well as dependent on the benevolence of particularly the stronger parliaments in the EU, it still seems like they are the most adequate solutions to the problems that were identified in this book. This is not to say that strengthening interparliamentary cooperation constitutes the perfect solution for the problems that the European Union faces with regard to the problems described in this book or that it is without any flaws. Nevertheless, the argument can be made that particularly in light of the other solution models proposed in this chapter - it could constitute a solution worth exploring as it neither requires a arduous Treaty change nor does it seem likely to be able to have any negative impact on representative democracy in the EU as it currently stands. Therefore, overall the conclusion of this book is the suggestion of stronger interparliamentary cooperation as the most suitable solution at this point in time to attempt to mitigate the differences in powers between the different national parlia- 
AN UNEVEN BALANCE?

ments and thus to ensure a more equal representation of the citizens of the different Member States. 


\section{Conclusion}

The purpose of this book was to analyze and understand the formal power asymmetries that exist between the national parliaments in the European Union and to consider the implications of such asymmetries for representative democracy in the EU. It took the European sovereign debt crisis as a cause to look into this particular issue because of the asymmetric impact that it had on the different national parliaments. As an addition to this analysis, the book in the end also illustrated different ways in which the negative implications for EU representative democracy that result from the described power asymmetries between national parliaments could be mitigated.

\subsection{SUMMARY OF THE RESEARCH}

The book started with a discussion of the concept of representative democracy and it explained the link between the notions of representation, accountability and responsibility thereunder, before it looked at the concept of representative democracy within the context of the European Union. It then described the role of the European Parliament and the national parliaments as the two kinds of representative organs in the EU by looking at their historical development and by outlining their current role and powers under the Treaties.

Chapters 4 and 5 then took a closer look at two specific national parliaments and compared their respective (formal) powers in relation to EU affairs. To that end, first a conceptual overview of the powers of national parliaments in domestic constitutional law was provided. Second, the constitutional frameworks under which the German Bundestag and the Irish Dáil Éireann participate in EU matters was examined with a special focus on their scrutiny powers vis-à-vis their governments in such matters. The comparative analysis showed that while the constitutional rules differ between the two respective parliaments - one example is the lack of a binding mandating power in the Irish parliament, which does exist in Germany - much of the difference in power could also be attributed to the political traditions of the respective Member States. In the Irish Dáil, issues relating to European affairs are not often considered to be high on the parliament's agenda. This is inter alia the result of the way the members of parliament in Ireland are elected, as elections are often won (and indeed lost) on constituency issues. The German Bundestag, on the other hand, enjoys a very strong position in EU affairs vis-à-vis the German government, which is in part also due to the requirements that have been promulgated by the German Federal Constitutional Court in this regard. 
The differences in power between national parliaments therefore have very different reasons. The comparison of these two national parliaments showed that, even before the crisis response measures were adopted at EU level which considerably exacerbated asymmetries in national parliaments' powers, there existed much difference in participation powers of national parliaments with regards to EU matters. From the beginning of the European project, the concept of dual representative democracy in the EU has never been homogeneous for all Member States. The line of democratic representation that is provided by the European Parliament is arguably, and at least insofar as it is envisioned in the Treaties, the same for all Union citizens. Leaving aside some issues with the way in which the EP is elected, Article 14(2) TEU unmistakably makes it clear that the Parliament is composed of representatives of the Union's citizens as a whole. This strand of democratic representation in the EU does not differentiate between the citizens of the different Member States.

This is different for the second line of representation that is provided for by the national parliaments when they hold their national governments to account for actions in the Council and the European Council. Because the conditions under which the national parliaments can scrutinize and control the latter is, and has always been, dependent on their respective constitutional framework as well as the political traditions in the Member State itself, the degree of representation for the citizens under this second strand differed, and still differs, from one Member State to the next. The situation changed to a certain extent, however, with the beginning of the European sovereign debt crisis in 2009 and with the various instruments that were adopted as a response thereto, which transferred some of the roots of such asymmetries from the national level to the European level.

In this regard, Chapter 6 examined more closely the way in which the crisis and the crisis response measures have affected this second line of democratic representation that is provided by the national parliaments. By analyzing the legal provisions of the European Stability Mechanism (ESM), the Treaty on Stability, Coordination and Governance in the Economic and Monetary Union (TSCG), the Six-Pack, and the Two-Pack, this chapter showed that the impact of these instruments on national parliaments varied greatly from parliament to parliament. Whether or not a parliament saw its budgetary and legislative powers eroded depended on a number of factors, but not least on the economic strength of its constituent Member State and whether or not its Member State had adopted the common currency. The chapter concluded that the asymmetric impact of the crisis on the different national parliaments increased already existing power asymmetries between national parliaments in the EU and, as a consequence, also had implications for the concept of dual democratic representation in the European Union. The question was thus asked as to whether or not it is possible to talk about two lines of democratic representation if, in fact, for some national parliaments such a second line does not actually exist, or at least was temporarily suspended during the Euro crisis. Instead, the citizens of those parliaments 
witnessed their national parliament retreat into the backbenches and, in the worst case, being dictated by the demands of other parliaments.

The seventh and last chapter looked into this problem further and first analyzed the implications of the asymmetries described in Chapter 6 for (dual) representative democracy in the EU and the Eurozone. The main implications are the disruption of the chain of accountability and thus a disruption of the notion of representation under the concept of representative democracy. In an ever more intertwined EU and especially in an ever more intertwined Eurozone, the national governments are no longer only responsible to their own national electorates. They also have to consider the preferences of the other Member States, who are affected by their decisions, all the while the power of national parliaments to participate in such decisions becomes increasingly differentiated. In a second instance, the chapter then looked into three different proposals for the future role of parliaments in the EU so as to mitigate the effects of such power asymmetries between national parliaments on EU representative democracy; namely the strengthening of the powers of the European Parliament, the creation of a new parliament for the Eurozone and the strengthening of the national parliaments though interparliamentary cooperation.

\subsection{RECOMMENDATIONS FOR THE FUTURE: INTERPARLIAMENTARY COOPERATION AS THE WAY FORWARD?}

This book proposed the creation of a new interparliamentary conference that is based on the Article 13 Conference of the Treaty on Stability, Coordination and Governance in the Economic and Monetary Union, but which only consists of members of the national parliaments of the Eurozone Member States as well as members of the European Parliament. Unlike the Article 13 Conference, such an interparliamentary conference for the Eurozone should have collective decision-making powers vis-à-vis the EU institutions, and, more specifically, the Eurogroup and the Euro summits. It should go beyond simply being forum for information exchange and beyond being a way for the European Parliament to use the national parliamentary views to lend support to its own recommendations to the other institutions in the context of the EU economic governance framework.

As per the current Treaty framework, there is no possibility to hold the ministers in the Eurogroup or the Heads of State or Government in the Euro summit collectively accountable for their actions. While it is not suggested that an interparliamentary conference for the Eurozone should have the power to sanction either the Eurogroup or the Euro summit, it could provide a forum in which decisions by the former two are discussed collectively by the national parliaments of those Member States that have representatives therein, instead of having 19 individual discussions on the same issue. It is also conceivable 
to introduce a practice whereby the President of the Eurogroup regularly appears before the conference to answer questions and to explain the decisions taken therein.

Through more coordination between the national parliaments and through more consideration of each other's interests in their own decision-making where it does not severely conflict with the interests of those they represent, national parliaments could mitigate the imbalance in powers that exist between them by collectively trying to achieve a result that is acceptable to more than just their own electorate. Such coordination should be done at national parliamentary level as opposed to within the Council or European Council. The reason for this is that government representatives in the Council are bound by their national parliaments' instructions at home, either through legally binding mandates or through other means of accountability such as ex post scrutiny. National parliaments, on the other hand, are not subject to the same constraints because they do not have to adhere to an explicit mandate in order to achieve a specific aim. This leaves them with more freedom to take into consideration other points of view and to come to more common solutions than would be possible in the Council in some circumstances.

Enhanced interparliamentary cooperation could, in addition, not only be beneficial to national parliaments as a whole, especially when it comes to making their views and opinions know towards the EU institutions, but it could also strengthen the powers of individual national parliaments towards their own government at national level and thereby mitigate the power imbalances between national parliaments themselves by aligning their powers in this regard. Through the exchange of best practices and information with each other, national parliaments may gain access to information that they would not necessarily have received under their own national constitutional frameworks because, for example, their information rights in EU affairs are rather limited. This of course is based on the assumption that those parliaments that already have extensive information rights under their domestic law are willing to participate in the conference and are also willing to share the information that they have with the other parliaments. The exchange of information is consequently most beneficial to weaker parliaments and possibly less so for stronger parliaments.

This last point is arguably also the biggest weakness of the proposal insofar as it is questionable whether stronger parliaments would see an added benefit in such a conference, the participation in which would require additional strain on the existent resources of parliament, which then in turn would be lacking elsewhere. It is similarly questionable whether stronger parliaments would be willing to endow the conference with more wideranging powers than was the case for the Article 13 Conference. With regards to the latter, it was after all one of the strongest parliaments, i.e., the German Bundestag, that opposed collective binding decision-making powers because it opined that such a position was reserved for the European Parliament as the representative organ of the EU. However, as was argued in Section 7.3.1.5 of Chapter 7, the strengthening of the European Parliament 
alone would not be sufficient to overcome the problems, with which dual representative democracy in the EU finds itself faced, either.

Therefore, all things considered - and at least for the time being and within the framework of the current Treaties - the best way forward or parliaments in the European Union in light of the imbalance of powers that exist between them seems to be the reinforcement of interparliamentary cooperation between the national parliaments (and the national parliaments and the European Parliaments), based on a relationship of mutual trust and mutual cooperation. 



\title{
BibliOgRAPHY
}

\author{
A Case law
}

BVerfG, Judgment of 30 June 2009 - 2 BvE 2/08.

BVerfG, Judgment of 01 July 2009 - 2 BvE 5/06.

BVerfG, Judgment of 07 September 2011 - 2 BvR 987/10.

BVerfG, Judgment of 28 February 2012 - 2 BvE 8/11.

BVerfG, Judgment of 19 June 2012 - 2 BvE 4/11.

BVerfG, Judgment of 12 September 2012 - 2 BvR 1390/12.

BVerfG, Judgment of 18 March 2014 - 2 BvR 1390/12.

Case 138/79 Roquette Frères v Council [1980] ECR 3333197.

Czech Constitutional Court, Judgement of 3 November 2009, Pl. ÚS 29/09: Treaty of Lisbon II.

\section{B Legislation}

Act concerning the election of the representatives of the Assembly by direct universal suffrage, [1976] OJ L278/5.

Act on the Assumption of Gurarantees within the Framework of a European Stabilisation Mechanism (Gesetz zur Übernahme von Gewährleistungen im Rahmen eines europäischen Stabilisierungsmechanismus - StabMechG) of 22 May 2010 (Federal Law Gazette I, p. 627), as amended by Article 1 of the Act of 9. October 2011 (Federal Law Gazette I, p. 1992)

Act on Cooperation between the Federal Government and the German Bundestag in Matters concerning the European Union (Gesetz über die Zusammenarbeit von Bun- 
desregierung und Deutschem Bundestag in Angelegenheiten der Europäischen Union EUZBBG) of 4 July 2013 (Federal Law Gazette I, p. 2170).

Act on the Exercise by the Bundestag and by the Bundesrat of their Responsibility for Integration in Matters concerning the European Union (Gesetz über die Wahrnehmung der Integrationsverantwortung des Bundestages und des Bundesrates in Angelegenheiten der Europäischen Union - IntVG) of 22 September 2009 (Federal Law Gazette I, p. 3022), as amended by Article 1 of the Act of 1 December 2009 (Federal Law Gazette I, p. 3822).

Act on Financial Participation in the European Stability Mechanism (Gesetz zur finanziellen Beteiligung am Europäischen Stabilitätsmechanismus - ESMFinG) of 13 September 2012 (Federal Law Gazette I, p. 1918).

Act regulating the status of the members of the German Bundestag (Gesetz über die Rechtsverhältnisse der Mitglieder des Deutschen Bundestages - AbgG) of 21 February 1996 (Federal Law Gazette I, p. 326), as last amended by Article 12 of the Act of 5 January 2017 (Federal Law Gazette I, p. 17).

Council Decision 87/373/EEC of 13 July 1987 laying down the procedures for the exercise of implementing powers, [1987] OJ L197/33.

Council Decision 1999/468 of 18 June 1999 laying down the procedures for the exercise of implementing powers conferred on the Commission, [1999] OJ L184/23.

Council Decision 2006/512/EC of 17 July 2006 amending Decision 1999/468/EC laying down the procedures for the exercise of implementing powers by the Commission, [2006] OJ L200/11.

Council Directive 2011/85/EU of 8 November 2011 on requirements for budgetary frameworks of the Member States, [2011] OJ L306/41.

Council Regulation (EU) No 1177/2011 of 8 November 2011 amending Regulation (EC) No $1467 / 97$ on speeding up and clarifying the implementation of the excessive deficit procedure, [2011] OJ L306/33.

Dáil Éireann Standing Orders Relative to Public Business Together With Oireachtas Library and Research Service Rules 2016, as published in January 2016, available at: $<$ www.oireachtas.ie/parliament/about/publications/standingorders/> (last retrieved on 10 October 2017). 
European Communities Act 1972, S.I. 1972/27.

European Communities Act 2007, S.I. 2007/18.

European Union Act 2009, S.I. 2009/33.

Federal Civil Service Act (Bundesbeamtengesetz - BBG) of 5 February 2009 (Federal Law Gazette I, p.160).

Joint Declaration by the European Parliament, the Council and the Commission of 4 March 1975 on the institution of a conciliation procedure between the Parliament and the Council, applicable to acts with significant financial implications, [1975] OJ C89/1.

Modus vivendi of 20 December 1994, among the European Parliament, the Council, and the Commission concerning the implementing measures for acts adopted in accordance with the procedure laid down in Article 189b of the EC Treaty, [1995] OJ C43/40.

Orders of Reference of the Dáil Select Committee on European Union Affairs of 8 June 2011.

Oireachtas (Ministerial and Parliamentary Offices) (Secretarial Facilities) Regulations 2016, S.I. 2016/599.

Orders of Reference of the Dáil Select Committee on European Union Affairs of 16 June 2011.

Regulation (EU) No 182/2011 of the European Parliament and the Council of 16 February 2011 laying down the rules and general principles concerning mechanisms for control by Member States of the Commission's exercise of implementing powers, [2011] OJ L55/13.

Regulation (EU) No 1173/2011 of the European Parliament and of the Council of 16 November 2011 on the effective enforcement of budgetary surveillance in the euro area, [2011] OJ L306/1.

Regulation (EU) No 1174/2011 of the European Parliament and of the Council of 16 November 2011 on enforcement measures to correct excessive macroeconomic imbalances in the euro area, [2011] OJ L306/8. 
Regulation (EU) No 1175/2011 of the European Parliament and of the Council of 16 November 2011 amending Council Regulation (EC) No 1466/97 on the strengthening of the surveillance of budgetary positions and the surveillance and coordination of economic policies, [2011] OJ L306/12.

Regulation (EU) No 1176/2011 of the European Parliament and of the Council of 16 November 2011 on the prevention and correction of macroeconomic imbalances, [2011] OJ L 306/186.

Regulation (EU) No 472/2013 of the European Parliament and of the Council of 21 May 2013 on the strengthening of economic and budgetary surveillance of Member States in the euro area experiencing or threatened with serious difficulties with respect to their financial stability, [2013] OJ L140/1.

Regulation (EU) No 473/2013 of the European Parliament and of the Council of 21 May 2013 on common provisions for monitoring and assessing draft budgetary plans and ensuring the correction of excessive deficit of the Member States in the euro area, [2013] OJ L140/11.

Rules of Procedure of the German Bundestag (Geschäftsordnung des Deutschen Bundestages) of 2 July 1980 (Federal Law Gazette I, p. 1237), as last amended on 12 June 2017 (Federal Law Gazette I, p. 1877).

Treaty establishing the European Stability Mechanism of 2 February 2012.

Treaty on Stability, Coordination and Governance in the Economic and Monetary Union of 2 March 2012.

\section{Political Documents and Reports}

Bundestag Drucksache 17/14601, "Unterrichtung durch den Präsidenten des Deutschen Bundestag: Erster Bericht über die Anwendung der Begleitsetze zum Vertrag von Lissabon", Report (2013), available at: <http://dipbt.bundestag.de/dip21/btd/17/146/1714601.pdf> (last retrieved on 11 September 2014).

Committee of Independent Experts, First Report on Allegations regarding Fraud, Mismanagement and Nepotism in the European Commission, 15 March 1999, available at: $<$ www.europarl.europa.eu/experts/pdf/reporten.pdf> (last retrieved on 22 March 2014). 
Conference of Speakers of the European Union Parliaments, Guidelines for Inter-Parliamentary Cooperation in the European Union (2008), available at: <www.ipex.eu/IPEXLWEB/euspeakers/getspeakers.do> (last retrieved on 31 October 2017).

COSAC, Draft Programme LVII COSAC meeting, available at: <www.ft.dk/samling/20161/almdel/euu/bilag/568/1743910.pdf> (last retrieved on 31 October 2017).

COSAC, Draft Programme LVI COSAC meeting, available at: < https://www.senato.it/application/xmanager/projects/leg17/file/b1-9\%20COSAC\%20Chairs\%20draft\%20programme\%20EN\%20-\%20update\%2001072016(1).pdf> (last retrieved on 31 October 2017).

COSAC, Draft Programme LV COSAC meeting, available at: <https://ghum.kuleuven.be/ggs/2016-06-meeting-of-the-plenary-cosac-draft.pdf > (last retrieved on 31 October 2017).

COSAC, Draft Programme LIV COSAC meeting, available at: $<$ https://www.senato.it/application/xmanager/projects/leg17/file/b1-9\%20POJ\%20LIV\%20COSAC\%20E\%20151125.pdf> (last retrieved on 31 October 2017).

European Commission, Annual Report 2012 on Subsidiarity and Proportionality, $\operatorname{COM}(2013) 566$ final.

European Commission, Annual Report 2012 on Relations between the European Commission and National Parliaments, COM (2013) 565 final.

European Commission, Annual Report 2013 on Subsidiarity and Proportionality, $\operatorname{COM}(2014) 506$ final.

European Commission, Annual Report 2013 on Relations between the European Commission and National Parliaments, COM (2014) 507 final.

European Commission, Annual Report 2014 on Subsidiarity and Proportionality, $\operatorname{COM}(2015) 315$ final.

European Commission, Annual Report 2014 on Relations between the European Commission and National Parliaments, COM (2015) 316 final.

European Commission, Communication of 30.11.2012, A Blueprint for a Deep and Genuine Economic and Monetary Union - Launching a European Debate, COM(2012) 777 final/2. 
European Commission, Directorate-General for Economic and Financial Affairs, Economic Adjustment Programme for Ireland, (2011) Occasional Papers 76.

European Commissioner Moscovici, Remarks on the Deepening of Europe's Economic and Monetary Union, available at: <http://europa.eu/rapid/press-release_SPEECH-171479_en.htm> (last retrieved on 31 October 2017).

European Council, Presidency Conclusions, Dublin Council, 25-26 June 1990, SN 60/1/90.

European Council, Presidency Conclusions, Rome Council, 14-15 December 1990, SN 242/1/90.

European Council, Presidency Conclusions, Brussels Council, 13 -14 December 2012, EUCO 205/12.

European Council, Laeken Declaration of 15 December on the future of the European Union, Annex I to Presidency Conclusions, Laeken Council, 14-15 December 2001, SN 300/1/01.

European Parliament, Resolution of 12 March 1968 on the election of members of the European Parliament [1968] OJ C41/12.

European Parliament, Resolution of 2 April 1998 on democratic accountability in the third phase of EMU [1998] OJ C138/177.

European Parliament, Resolution of 31 May 2001 on the Treaty of Nice and the future of the European Union.

European Parliament, "Codecision and Conciliation - A Guide to how the Parliament colegislates under the Treaty of Lisbon", (2012), available at <www.europarl.europa.eu/ code/information/guide_en.pdf> (last retrieved on 26 March 2014).

European Parliament, Resolution of 20 November 2012 with recommendations to the Commission on the report of the Presidents of the European Council, the European Commission, the European Central Bank and the Eurogroup "Towards a genuine Economic and Monetary Union" (2012/2151(INI)).

European Parliament, Resolution of 20 December 2013, Constitutional Problems of a Multitier Governance in the European Union, (2012/2078(INI)). 
House of Commons, The European Scrutiny System in the House of Commons - A Short Guide for Member of Parliament by the Staff of the European Scrutiny Committee, available at: <https://www.parliament.uk/documents/upload/theeuroscrutinysysteminthehoc.pdf $>$ (last retrieved on 31 October 2017).

House of Commons, Resolution of 17 November 1998 on the Scrutiny Reserve.

House of Lords, European Union Committee, Report on 2014-2015, published 3 July 2015, HL Paper 11.

Joint Committee on European Scrutiny, Eighth Annual Report on the Operation of the European Union (Scrutiny Act) 2002, (January 2011) available at: <www.oireachtas.ie/viewdoc.asp? DocID=17522\&CatID=78\&StartDate=01\%20January\%202011\&OrderAscending $=0>$ (last retrieved on 18 May 2015).

Joint Committee on European Union Affairs, Work Programme 2014, (February 2014) available at: <www.oireachtas.ie/parliament/media/committees/euaffairs/JCEUA-WorkProgramme-2014.pdf> (last retrieved on 15 May 2015).

Joint Committee on European Union Affairs, EU Scrutiny Work Programme 2014: Joint Committee's Priorities, (March 2014) available at: <www.oireachtas.ie/parliament/media/committees/euaffairs/Oireachtas-EU-Scrutiny-Priorities-2014-FINAL.pdf> (last retrieved on 18 May 2015).

Joint Committee on European Union Affairs, Assessment of Current Structures for Oireachtas Scrutiny of EU Affairs, (April 2014) available at: <www.oireachtas.ie/parliament/media/committees/euaffairs/Review-of-Structures-for-Oireachtas-Scrutiny-of-EUAffairs_JCEUA-Report_April-2014.pdf> (last retrieved on 18 May 2015).

L'Assemblée Nationale, Fiche de synthèse n56: L'assemblée nationale et les questions europénnes, available at: <www2.assemblee-nationale.fr/decouvrir-l-assemblee/role-etpouvoirs-de-l-assemblee-nationale/l-assemblee-nationale-et-les-questions-europeennes/lassemblee-nationale-et-les-questions-europeennes $>$ (last retrieved on 31 October 2017).

E. Macron, Programme En Marche! - Élection Présidentielle 23 Avril et 7 Mai 2017, available at: <https://storage.googleapis.com/en-marche-fr/COMMUNICATION/ProgrammeEmmanuel-Macron.pdf> (last retrieved on 1 November 2017). 
Taoiseach, Statement of Common Purpose of Irish Government, 2011, available at: <https://www.taoiseach.gov.ie/eng/Publications/Publications_Archive/Publications_2011/Programme_for_Government_2011.pdf> (last retrieved on 9 October 2017).

\section{SECONDARY SOURCES}

G. Abels, "Parlamentarische Kontrolle im Mehrebenensystem der EU- ein unmögliches Unterfangen?”, in B. Eberbach-Born, S. Kropp, A. Stuchlik, W. Zeh (eds.), Parlamentarische Kontrolle und Europäische Union, Nomos: Baden-Baden, 2013, pp. 79-102.

K. Auel, "Democratic Accountability and National Parliaments: Redefining the Impact of Parliamentary Scrutiny in EU Affairs”, (2007) 13 European Law Journal, pp. 487-504.

K. Auel, "De-Parliamentatisation Re-considered - Domestic Parliamentary Representation in EU Affairs", (2012) Paper prepared for the Annual Meeting of the American Political Science Association (APSA), New Orleans, September 2012.

K. Auel, O. Rozenberg, A. Thomas, "Lost in Transaction? Parliamentary Reserves in EU Bargains”, (2012) OPAL Online Paper Series No. 10/2012.

K. Auel, T. Raunio, "Debating the State of the Union: Comparing Parliamentary Debates on EU Issues in Finland, France, Germany and the United Kingdom”, (2014) 20 The Journal of Legislative Studies, pp. 13-28.

K. Auel, O. Rozenberg, A. Tacea, "Fighting Back? And, If So, How? Measuring Parliamentary Strength and Activity in EU Affairs", in: C. Hefftler, C. Neuhold, O. Rozenberg, J. Smith (eds.), The Palgrave Handbook of National Parliaments and the European Union, Palgrave Macmillan: United Kingdom, 2015, pp. 60-93.

K. Auel, O. Höing, "Scrutiny in Challenging Times - National Parliaments in the Eurozone Crisis”, (2014) Sieps European Policy Analysis.

K. Auel, O. Höing, "Parliaments in the Euro Crisis: Can the Losers of Integration Still Fight Back?”, (2014) 52 Journal of Common Market Studies, pp. 1184-1193.

C. Archer, The European Union: Structure and Process, $3^{\text {rd }}$ ed., Continuum International Publishing: New York, 2000. 
G. Barrett, "Oireachtas Control over Government Activity at European Union Level: Reflections on the Historical Context and the Legal Framework", in G. Barrett (ed.), National Parliaments and the European Union: The Constitutional Challenge for the Oireachtas and Other Member State Legislatures, Clarus Press: Ireland, 2008, pp. 145-178.

G. Barrett, "Reviewing the Role of the Oireachtas in European Affairs", (2010) IIEA Paper delivered on 5 May, 2010 to the Joint Oireachtas Sub-Committee on the Review of the Role of the Oireachtas on European Affairs.

G. Barrett, "Long Train Running: The Slowly Developed (and Slowly Developing) Role of Ireland's Oireachtas in EU Affairs", in C. Hefftler, C. Neuhold, O. Rozenberg, J. Smith (eds.), The Palgrave Handbook of National Parliaments and the European Union, Palgrave Macmillan: United Kingdom, 2015, pp. 290-311.

R. Bellamy, "Democracy Without Democracy? Can the EU's Democratic 'Outputs' be Separated from the Democratic 'Inputs' Provided by Competitive Parties and Majority Rule?", (2010) 17 Journal of European Public Policy, pp. 2-19.

R. Bellamy, D. Castiglione, "Three Models of Democracy, Political Community and Representation in the EU”, (2013) 20 Journal of European Public Policy, pp. 206-223.

A. Benz, J. Broschek, "Nationale Parlamente in der Europäischen Politik - Funktionen, Probleme und Lösungen”, (2010) Friedrich-Ebert-Stiftung, Internationale Politikanalyse.

A. Benz, "An Asymmetric Two-Level Game: Parliaments in the Euro Crisis”, in: B. Crum, J.E. Fossum (eds.), Practices of Inter-Parliamentary Coordination in International Politics - The European Union and Beyond, ECPR Press: United Kingdom, 2013, pp. 125-141.

T. Bergman, "National Parliaments and EU Affairs Committees: Notes on Empirical Variation and Competing Explanations", (1997) 4 Journal of Public Policy, pp. 371-487.

T. Beukers, “The Eurozone Crisis and the Legitimacy of Differentiated Integration”, (2013) EUI Working Papers MWP 2013/36.

R. Bieber, J. Pantalis, J. Schoo, "Implications of the Single Act for the European Parliament", (1986) 23 Common Market Law Review, pp. 767-792. 
L.C. Blichner, "The Anonymous Head of Public Reason - Interparliamentary Discourse and the Quest for Legitimacy", in: E.O. Eriksen, J.E. Fossum (eds.), Democracy in the European Union - Integration through Deliberation?, Routledge: USA, 2000, pp. 141-163.

E.W. Böckenförde, Staat, Verfassung, Demokratie: Studien zur Verfassungstheorie und zum Verfassungsrecht, Suhrkamp: Frankfurt am Main, 1991.

A. von Bogdandy, "Globalization and Europe: How to Square Democracy, Globalization and International Law”, (2004) 15 The European Journal of International Law, pp. 885906.

A. von Bogdandy, “A Disputed Idea Becomes Law: Remarks on European Democracy as a Legal Principle", in B. Kohler-Koch, B. Rittberger (eds.), Debating the Democratic Legitimacy of the European Union, Rowman \& Littlefield Publishers: USA, 2007, pp. 33-44.

A. von Bogdandy, "The European Lesson for International Democracy: The Significance of Articles 9-12 EU Treaty for International Organizations", (2012) 23 The European Journal of International Law, pp. 315-334.

M. Bovens, "New Forms of Accountability and EU-Governance", (2007) 5 Comparative European Politics, pp. 104-120.

S. Bredt, "Prospects and Limits of Democratic Governance in the EU", (2011) 17 European Law Journal, pp. 35-65.

J. Brehm, S. Gates, Working, Shirking and Sabotage - Bureaucratic Response to a Democratic Public, University of Michigan Press: Michigan, USA, 1999.

J. O’Brennan, “Introduction: Deparliamentarization through European Integration?”, in: J. O'Brennan, T. Raunio (eds.), National ParliamentsWithin the Enlarged European Union: From 'Victims' of Integration to Competitive Actors?, Routledge: United Kingdom, 2007, pp. 1-25.

D. Capuano, "The role of COSAC in the Europeanisation of National Parliaments and in the Evolution of Interparliamentary Cooperation", in: N. Lupo, C. Fasone (eds.), Interparliamentary Cooperation in the Composite European Constitution, Hart Publishing: United Kingdom, 2016. 
F. Cheneval, F. Schimmelfennig, "The Case for Demoicracy in the European Union", (2012) 51 Journal of Common Market Studies, pp. 334-350.

T. Christiansen, A.L. Högenauer, C. Neuhold, "National Parliaments in the post-Lisbon European Union: Bureaucratization rather than Democratization?”, (2014) 12 Comparative European Politics, pp. 121-140.

B. Chubb, The Government and Politics of Ireland, Stanford University Press: Stanford, USA, 1982.

P. Coenen, A.W. Heringa, H.T. Nguyen, S. Wolf, “Europees Semester”, (2015) Montesquieu Institute Policy Paper Nr. 6.

P. Conlan, "Ireland: Enhanced Parliamentary Scrutiny of European Affairs: But is it Effective?”, in J. O’Brennan, T. Raunio (eds.), National Parliaments Within the Enlarged European Union - From 'Victims' of Integration to Competitive Actors?, Routledge: United Kingdom, 2007, pp. 178-199.

I. Cooper, "The Emerging Order of Interparliamentary Cooperation in the Post-Lisbon EU”, in D. Jancic (ed.), National Parliaments after the Lisbon Treaty and the Euro Crisis Resilience or Resignation?, Oxford University Press: United Kingdom, 2017, pp. 227-246.

I. Cooper, "The Politicization of Interparliamentary Relations in the EU: Constructing and Contesting the Article 13 Conference on Economic Governance", (2016) 14 Comparative European Politics, pp. 196-214.

R. Corbett, F. Jacobs, M. Shackleton, “The European Parliament at Fifty: A View from the Inside", (2003) 41 Journal of Common Market Studies, pp. 353-373.

R. Corbett, F. Jacobs, M. Shackleton, The European Parliament, $8^{\text {th }}$ ed., John Harper Publishing: London, 2011.

P. Craig, The Lisbon Treaty - Law, Politics, and Treaty Reform, Oxford University Press: Oxford, 2010.

P. Craig, "Delegated Acts, Implementing Acts and the New Comitology Regulation", (2011) 36 European Law Review, pp. 671-687. 
P. Craig, G. de Burca, EU Law - Texts, Cases and Materials, $5^{\text {th }}$ ed., Oxford University Press: Oxford, 2011.

B. Crum, "Acountability and Personalization of the European Council Presidency", (2009) 31 Journal of European Integration, pp. 685-701.

B. Crum, J.E. Fossum, "Conclusion: Towards a Democratic Multilevel Parliamentary Field?”, in B. Crum, J.E. Fossum (eds.), Practices of Interparliamentary Coordination in International Politics in the European Union and Beyond, ECPR Press: 2013, pp. 251-268.

D. Curtin, "Challenging Executive Dominance in European Democracy", (2014) in 77 The Modern Law Review, pp. 1-32.

A. Cygan, "COSAC: Birth, Evolution, Failures and Perspectives", in: N. Lupo, C. Fasone (eds.), Interparliamentary Cooperation in the Composite European Constitution, Hart Publishing: United Kingdom, 2016, pp. 207-226.

M. Dawson, “Economic and Monetary Union: Maastricht's Great Failure”, in: M. De Visser, A. P. Van der Mei, The Treaty on European Union 1993-2013: Reflections from Maastricht, Intersentia: Antwerp, 2013, pp. 475- 492.

M. Dawson, “The Legal and Political Accountability Structure of 'Post-Crisis' EU Economic Governance”, (2015) Journal of Common Market Studies, pp. 976-993.

S. Douglas-Scott, “The Law And Custom of the European Parliament”, in K.S. Ziegler, D. Baranger, A.W. Bradley (eds.), Constitutionalism and the Role of Parliaments, Hart Publishing: Oxford, 2007, pp.79-95.

C.D. Ehlermann, “Increased Differentiation or Stronger Uniformity?”, (1995) EUI Working Paper RSC No. 95/21.

European Parliament, Directorate-General for Internal Policies, Policy Department Citizens' Rights and Constitutional Affairs, "Democratic Control in the Member States of the European Council and the Eurozone Summits", Study (2013).

European Parliament, Directorate-General for Internal Policies, Policy Department Citizens' Rights and Constitutional Affairs, "Democratic Control in the Member States of the European Council and the Eurozone Summits: In-depth Reports on 12 Member States", Annex 2 (2013). 
F. Fabbrini, Economic Governance in Europe: Comparative Paradoxes and Constitutional Challenges, Oxford University Press: United Kingdom, 2016.

S. Fabbrini, “Intergovernmentalism and Its Limits: Assessing the European Union's Answer to the Euro Crisis", (2013) 46 Comparative Political Studies, pp. 1003-1029.

S. Fabbrini, "After the Euro Crisis: A New Paradigm on the Integration of Europe”, (2014) ARENA Working Paper 5.

E. Fahey, "Reflections on the Legal Role of the Irish Parliament (Oireachtas) in EU Affairs after Lisbon”, (2010) EUI Working Papers MWP 2010/20.

C. Fasone, "The Struggle of the European Parliament to Participate in the New Economic Governance”, (2012) EUI Working Papers RSCAS 2012/45.

C. Fasone, "Eurozone, non-Eurozone and 'troubled asymmetries' among national parliaments in the EU. Why and to what extent this is of concern", (2014) 6 Perspectives on Federalism, pp. 1-41.

C. Fasone, "European Economic Governance and Parliamentary Representation. What Place for the European Parliament?”, (2014) 20 European Law Journal, pp. 164-185.

C. Fasone, “Taking Budgetary Powers Away From National Parliaments? On Parliamentary Prerogatives in the Eurozone Crisis", (2015) EUI Working Papers LAW 2015/37.

J. Fischer, "From Confederacy to Federation: Thoughts on the Finality of European Integration", Speech at the Humboldt University in Berlin, 12 May 2000, in: C. Joerges, Y. Meny, J.H.H. Weiler (eds.), What Kind of Constitution for What Kind of Polity? - Responses to Joschka Fischer, Robert Schuman Centre for Advanced Studies, European University Institute: Florence, 2000, pp. 19-30.

D. Finke, T. Dannwolf, "Domestic Scrutiny of European Union Politics: Between Whistle Blowing and Opposition Control”, (2013) European Journal of Political Research, pp. 715746.

A. Follesdal, S. Hix, "Why there is a Democratic Deficit in the EU: A Response to Majone and Moravcsik", (2006) 44 Journal of Common Market Studies, pp. 533-562. 
J.E. Fossum, "Democracy and Differentiation in Europe", (2015) 22 Journal of European Public Policy, pp. 799-815.

J.E. Fossum, “The Structure of EU Representation and the Crisis, in in: S. Kröger (ed.), Political Representation in the European Union - Still Democratic in Times of Crisis?, Routledge: United Kingdom, 2014, pp. 52-68.

D. Fromage, "Increasing Inter-Parliamentary Cooperation in the European Union: Current Trends and Challenges", (2016) 22 European Public Law, pp. 749-772.

M. Gallagher, "Parliament”, in J. Coakley, M. Gallagher (eds.), Politics in the Republic of Ireland, Routledge: United Kingdom, 2005, pp. 211-241.

M. Gallagher, “The Oireachtas: President and Parliament”, in J. Coakley, M. Gallagher (eds.) Politics in the Republic of Ireland, PSAI Press: United Kingdom, 2010, pp. 198-229.

D. Gaus, "Two Kinds of Democratic Legitimacy for the EU? Input- and Output-Oriented Legitimacy as a Case of Conceptual Misformation", (2010) Paper presented at the conference 'Democracy as Idea and Practice', Oslo 14-15 January 2010.

A. Groen, T. Christiansen, "National Parliaments in the European Union: Conceptual Choices in the European Union's Constitutional Debate", in: C. Hefftler, C. Neuhold, O. Rozenberg, J. Smith, The Palgrave Handbook of National Parliaments and the European Union, Palgrave Macmillan: United Kingdom, 2015, pp. 43-59.

S. Guerrieri, “The Evolution of the European Parliament's Role before the Direct Elections (1952-1979)", in: D. Preda, D. Pasquinucci (eds.), The Road Europe Travelled Along - The Evolution of the EEC/EU Institutions and Policies, P.I.E. Peter Lang: Brussels, 2010, pp. 203-214.

J. Habermas, The Crisis of the European Union: A Response, Polity Press: United Kingdom, 2012.

M. Hallerberg, B. Marzinotto, G. Wolff, “An Assessment of the European Semester”, (2012) Study for the European Parliament's Committee on Economic and Monetary Affairs.

C. Hefftler, “An Ever Closer Interparliamentary Network? National Parliaments' Priorities in Interparliamentary Cooperation in the EU", Paper for EUSA Conference, Boston, 5-7 March 2015. 
C. Hefftler, K. Gattermann, "Interparliamentary Cooperation in the European Union: Patterns, Problems and Potential”, in: C. Hefftler, C. Neuhold, O. Rozenberg, J. Smith (eds.), The Palgrave Handbook of National Parliaments and the European Union, Palgrave Macmillan: United Kingdom, 2015, pp. 94-115.

C. Hefftler, W. Wessels, “The Democratic Legitimacy of the EU's Economic Governance and National Parliaments", (2013) IAI Papers Working 13|13.

L. O’Hegarty, "Parliamentary Scrutiny of European Affairs in Ireland - The European Affairs Committee, the Scrutiny Committee and the European Union (Scrutiny) Act 2002", in G. Barrett (ed.), National Parliaments and the European Union: The Constitutional Challenge for the Oireachtas and Other Member State Legislatures, Clarus Press: Ireland, 2008, pp. 273-307.

N. Heinen, A. Theiss, "EFSF - Where Do National Parliaments Have a Say in the EMU?", (2011) Deutsche Bank Research.

M. Heipertz, A. Verdun, Ruling Europe - The Politics of the Stability and Growth Pact, Cambridge University Press: United Kingdom, 2010.

S. Hix, The Political System of the European Union, $2^{\text {nd }}$ ed., Palgrave Macmillan: New York, 2005.

A.L. Högenauer, "The Administrations of National Parliaments and the Scrutiny of EU Affairs”, in A.L. Högenauer (ed.), Parliamentary Administrations in the European Union, Palgrave Macmillan: United Kingdom, 2016, pp. 69-89.

A.L. Högenauer, T. Christiansen, "Parliamentary Administrations in the Scrutiny of EU Decision-Making”, in C. Hefftler, C. Neuhold, O. Rozenberg, J. Smith (eds.), The Palgrave Handbook of National Parliaments and the European Union, Palgrave Macmillan: United Kingdom, 2015, pp. 116-132.

A.L. Högenauer, C. Neuhold, "National Parliaments after Lisbon: Administrations on the Rise?”, (2015) 38 West European Politics, pp. 335-354.

O. Höing, "Differentiation of Parliamentary Powers - The German Constitutional Court and the German Bundestag Within the Financial Crisis", (2012) OPAL Online Paper Series | 9/12. 
O. Höing, "With a Little Help of the Constitutional Court: The Bundestag on Its Way to an Active Policy Shaper", in C. Hefftler, C. Neuhold, O. Rozenberg, J. Smith (eds.), The Palgrave Handbook of National Parliaments and the European Union, Palgrave Macmillan: United Kingdom, 2015, pp. 191-208.

S. Hölscheidt, "Parlamentarische Kontrolle in der Eurokrise", in B. Eberbach-Born, S. Kropp, A. Stuchlik, W. Zeh (eds.), Parlamentarische Kontrolle und Europäische Union, Nomos: Baden-Baden, 2013, pp. 105-129.

R. Holzhacker, "Democratic Legitimacy and the European Union", (2007) 29 European Integration, pp. 257-269.

N. Jabko, "Democracy in the Age of the Euro", (2003) 10 Journal of European Public Policy, pp. 710-739.

D. Jancic, "Caveats from Karlsruhe and Berlin: Whither Democracy After Lisbon?", (2010) 16 Columbia Journal of European Law, pp. 337-383.

D. Jancic, "Representative Democracy Across Levels? National Parliaments and EU Constitutionalism", (2012) 8 Croatian Yearbook of European Law and Policy, pp. 227-265.

D. Jancic, "National Parliaments and EU Fiscal Integration", (2016) 22 European Law Journal, pp. 225-249.

D. Jancic, "Parliamentary Involvement in the Economic and Monetary Union after the Euro Crisis”, in: N. Lupo, C. Fasone (eds.), Interparliamentary Cooperation in the Composite European Constitution, Hart Publishing: United Kingdom, 2016, pp. 184-204.

E. Jurgens, "Federal Option for European Communities or a Permanent Democracy Deficit?", in C. Flinterman, A.W. Heringa, L. Waddington (eds.), The Evolving Role of Parliaments in Europe, Maklu Uitgevers: Antwerp, 1995, pp. 83-89.

R. Kardasheva, “The Power to Delay: The European Parliament's Influence in the Consultation Procedure”, (2009) 47 Journal of Common Market Studies, pp. 385-409.

P. Kiiver, The National Parliaments in the European Union - A Critical View on EU Constitution-Building, Kluwer Law International: The Hague, 2006. 
V. Knutelska, "Cooperation among National Parliaments: An Effective Contribution to EU Legitimation?”, in B. Crum and J.E. Fossum (eds.), Practices of Interparliamentary Coordination in International Politics, the European Union and Beyond, ECPR Press: United Kingdom, 2013, pp. 33-49.

V. Kreilinger, "Interparliamentary Cooperation and its Challenges: The Case of Economic and Financial Governance", in: F. Fabbrini, E. Hirsch Ballin, H. Somsen (eds.), What Form of Government fort he European Union and the Eurozone?, Hart Publishing: Oxford, 2015, pp. 271-288.

V. Kreilinger, “The New Inter-Parliamentary Conference for Economic and Financial Governance”, (2013) Policy Paper Notre Europe October 2013.

M. Kohler, "European Governance and the European Parliament: From Talking Shop to Legislative Powerhouse”, (2013) Journal of Common Market Studies, pp. 1-16.

B. Laffan, J. O’Mahony, “Managing Europe From Home: The Europeanisation of the Irish Core Executive”, (2003) Report on the Irish Case Study, Dublin European Institute, National University of Ireland.

B. Laffan, "Testing Times: The Growing Primacy of Responsibility in the Euro Area", (2014) 37 West European Politics, pp. 270-278.

N. Lasan, "How far can the European Parliament Correct the European Union's Democratic Deficit?”, (2008) 8 Romanian Journal of European Affairs, pp. 18-26.

R. Lastra, "Central Banking after the Crisis" (2010) 13 International Finance, pp. 321-340.

K. Lenaerts, P. Van Nuffel, Constitutional Law of the European Union, $2^{\text {nd }}$ ed., Sweet \& Maxwell Limited: London, 2005.

K. Lenaerts, N. Cambien, "The Democratic Legitimacy of the EU after the Treaty of Lisbon", in J. Wouters, L. Verhey, P. Kiiver (eds.), European Constitutionalism beyond Lisbon, Intersentia: Antwerp, 2009, pp. 185-207.

C. Lord, "Democracy and Democratization in the European Union", in S. Bromley (ed.), Governing the European Union, SAGE Publications: London, 2001, pp. 165-190. 
A. Lupia, "Delegation and its Perils", in K. Strom, W. Müller, T. Bergman (eds.), Delegation and Accountability in Parliamentary Democracies, Oxford University Press: New York, USA, 2006, pp. 33-54.

M. Maccarthaig, Accountability in Irish Parliamentary Politics, Institute of Public Administration: Ireland, 2005.

M. Maccarthaigh, "Accountability through national parliaments: practice and problems”, in J. O'Brennan, T. Raunio (eds.), National Parliaments Within the Enlarged European Union - From, Victims ' of Integration to Competitive Actors?, Routledge: United Kingdom, 2007, pp. 29-45.

P. Mair, "Representative versus Responsible Government", (2009) MPIfG Working Paper 09/8.

P. Mair, On Parties, Party System and Democracy: Selected Writings of Peter Mair, edited by I. Van Biezen, ECPR: United Kingdom, 2014.

B. Manin, The Principles of Representative Government, Cambridge University Press: United Kingdom, 1997.

G. Majone, “Europe's 'Democratic Deficit': The Question of Standards”, (1998) 4 European Law Journal, pp. 5-28.

R. Matarazzo (ed.), Democracy in the EU After the Lisbon Treaty, Edizioni Nuova Culture: Rome, 2011.

A. Maurer, "The Legislative Powers and Impact of the European Parliament", (2003) (41) Journal of Common Market Studies, pp. 227-247.

A. Maurer, "From EMU to DEMU: The Democratic Legitimacy of the EU and the European Parliament", (2013) IAI Working Papers 13|11.

A. Maurer, W. Wessels (eds.), National Parliaments on their Ways to Europe: Losers or Latecomers?, Nomos: Baden-Baden, 2001.

A. Maurer, "National Parliaments in the European Architecture: From Latecomers' Adaptation towards Permanent Institutional Change?", in: A. Maurer, W. Wessels (eds.), 
National Parliaments on their Ways to Europe: Losers or Latecomers?, Nomos: BadenBaden, 2001, pp. 27-76.

A. Maurer, W. Wessels, "National Parliaments after Amsterdam: From Slow Adapters to National Players?", in: A. Maurer, W. Wessels (eds.), National Parliaments on their Ways to Europe: Losers or Latecomers?, Nomos Verlagsgesellschaft: Baden-Baden, Germany, 2001, pp. 425-475.

J. Mayoral, "Democratic Improvements in the European Union under the Lisbon Treaty - Institutional Changes Regarding Democratic Government in the EU”, (2011) European Union Democracy Observatory (EUDO).

K. Meenan, "What is the Role of a Committee on European Affairs?", in G. Barrett (ed.), National Parliaments and the European Union: The Constitutional Challenge for the Oireachtas and Other Member State Legislatures, Clarus Press: Ireland, 2008.

A. Menon, S. Weatherill, "Democratic Politics in a Globalizing World: Supranationalism and Legitimacy in the European Union", (2007) LSE, Law, Society and Economy Working Papers 13/2007.

A. Menon, J. Peet, “Beyond the European Parliament: Rethinking the EU's Democratic Legitimacy”, (2010) Centre for European Reform Essays.

Y. Meny (ed.), Building Parliament: 50 Years of European Parliament History 1958-2008, Office for Official Publications of the European Communities: Luxembourg, 2009.

J.S. Mill, Considerations on Representative Government, Serenity Publishers: USA, 2008 [1861].

P. Mitchell, "Ireland: 'O What a Tangled Web...' - Delegation, Accountability and Executive Power”, in K. Strom, W. Müller, T. Bergman (eds.), Delegation and Accountability in Parliamentary Democracies, Oxford University Press: New York, USA, 2006, pp. 418-444.

A. Moravcsik, "In Defence of the 'Democratic Deficit': Reassessing Legitimacy in the European Union”, (2002) 40 Journal of Common Market Studies, pp. 603-624.

R. Mulgan, “Accountability’: An Ever-Expanding Concept?”, (2000) 78 Public Administration, pp. 555-573. 
W. Müller, T. Bergman, K. Strom, "Parliamentary Democracy: Promise and Problems", in K. Strom, W. Müller, T. Bergman (eds.), Delegation and Accountability in Parliamentary Democracies, Oxford University Press: New York, USA, 2006, pp. 3-32.

M. Murphy, "Reform of Dáil Éireann: The Dynamics of Parliamentary Change", (2006) 59 Parliamentary Affairs, pp. 437-453.

M. Nettesheim, "Developing a Theory of Democracy for the European Union”, (2005) 23 Berkeley Journal of International Law, pp. 358-400.

C. Neuhold, "Late Wake-Up Call or Early Warning? Parliamentary Participation and Cooperation in Light of the Treaty of Lisbon", Paper prepared for the UACES Conference: The Lisbon Treaty Evaluated: Impact and Consequences, London, 31 January - 1 February 2011.

K. Nicolaidis, "European Demoicracy and Its Crisis”, (2012) 51 Journal of Common Market Studies, pp. 351-369.

P. Norton, “Conclusion: Addressing the Democratic Deficit", (1995) 1 Journal of Legislative Studies, pp. 177-193.

D. Oliver, "Executive Accountability: A Key Concept", in L. Verhey, P. Kiiver, S. Loeffen (eds.), Political Accountability and European Integration, Europa Law Publishing: Groningen, 2009, pp. 11-31.

W. Patzelt, "What can an Individual MP do in German Parliamentary Politics?", in L. Longley, R. Hazan (eds.), The Uneasy Relationship between Parliamentary Members and Leaders, Frank Cass Publishers: New York, USA, 2000, pp. 23-52.

L. Pech, "The Institutional Development of the EU Post-Lisbon", in D. Ashiagbor, N. Countouris, I. Lianos (eds.), The European Union after the Treaty of Lisbon, Cambridge University Press: Cambridge, 2012, pp. 7-46.

S. Piattoni, “The European Union: Legitimating Values, Democratic Principles and Institutional Architectures", in: S. Piattoni (eds.), The European Union - Democratic Principles and Institutional Architectures in Times of Crisis, Oxford University Press: United Kingdom, 2015, pp. 3-25. 
S. Piattoni, "Is the EU a Representative Democracy? The Normative Debate and the Impact of the Euro Crisis", in: F. Fabbrini, E. Hirsch Ballin, H. Somsen (eds.), What Form of Government for the European Union and the Eurozone?, Hart Publishing: United Kingdom, 2015, pp. 133-149.

F. Piodi, “Towards Direct Elections to the European Parliament - Paper Written to Mark the $30^{\text {th }}$ Anniversary of Direct Elections", (2009) Directorate-General for the Presidency Archive and Documentation Centre (CARDOC) Journal.

J.C. Piris, The Lisbon Treaty - A Legal and Political Analysis, Cambridge University Press: Cambridge, 2010.

H. Pitkin, The Concept of Representation, University of California Press: United States, 1967.

J. Pollak, "Compounded Representation in the EU: No Country for Old Parliaments?", in S. Kröger (ed.), Political Representation in the European Union - Still Democratic in Times of Crisis?, Routledge: United Kingdom, 2014, pp. 19-35.

A. Randelzhofer, "Zum Behaupteten Demokratiedefizit der Europäischen Gemeinschaft", in P. Hommelhoff, Der Staatenverbund der Europäischen Union: Beiträge und Diskussionen des Symposiums am 21./22. Januar 1994 in Heidelberg, Heidelberg Müller Juristischer Verlag: Heidelberg, 1994, pp. 39-55.

T. Range, "Europäische Verfassung: Neue EU-Kompetenzen für den Deutschen Bundestag”, (2004) Konrad-Adenauer-Stiftung Working Paper No. 136/2004.

T. Raunio, “Always One Step Behind? National Legislatures and the European Union”, (1999) 34 Government and Opposition, pp. 180-202.

T. Raunio, "Holding Governments Accountable in European Affairs: Explaining CrossNational Variation", in K. Auel, A. Benz (eds.), The Europeanisation of Parliamentary Democracy, Routledge: United Kingdom, 2006, pp. 17-40.

T. Raunio, "National Parliaments and European Integration - What we know and what we should know", (2009) ARENA Working Paper No. 02.

T. Raunio, S. Hix, "Backbenchers Lean to Fight Back: European Integration and Parliamentary Government”, (2000) 23 West European Politics, pp. 142-168. 
B. Rittberger, "Constructing Parliamentary Democracy in the European Union: How Did It Happen?", in in B. Kohler-Koch, B. Rittberger, Debating the Democratic Legitimacy of the European Union, Rowman \& Littlefield Publishers: USA, 2007, pp. 111-138.

R. Rose, "Responsible Party Government in a World of Interdependence", (2014) 37 West European Politics, pp. 253-269.

W. Sadurski, "Democratic Legitimacy of the European Union: A Diagnosis and Some Modest Proposals", Sydney Law School Legal Studies Research Paper No. 13/29.

J.D. Savage, D. Howarth, "Enforcing the European Semester: The Politics of Asymmetric Information in the Excessive Deficit and Macroeconomic Imbalance Procedures", (2018) 25 Journal of European Public Policy, pp. 212-230.

A. Schaefer, "Die Demokratische Grenze Output-Orientierter Legitimation", (2006) 29 Integration, pp. 187-200.

F.W. Scharpf, "Economic Integration, Democracy and the Welfare State”, (1997) 4 Journal of European Public Policy, pp. 18-36.

F.W. Scharpf, "Interdependence and Democratic Legitimation", (1998) MPIfG Working Paper 98/2.

F.W. Scharpf, Governing in Europe: Effective and Democratic?, Oxford University Press: Oxford, 1999.

F. W. Scharpf, "No Exit From the Euro-Rescuing Trap?”, (2014) MPIfG Discussion Paper 14/4.

A. Schedler, "Conceptualizing Accountability", in A. Schedler, L. Diamond, M. Plattner, The Self-Restraining State, Lyenne Rienne Publishers: Colorado, USA, 1999, pp. 13-28.

H. Scheller, "Fiscal Governance und Demokratie in Krisenzeiten", (2012) 13 Aus Politik und Zeitgeschichte, pp. 9-16.

H.G. Schermers, N.M. Blokker, International Institutional Law: Unity Within Diversity, Koninklijke Brill NV: Leiden, 2011. 
H. Schmitt, “The European Parliament Elections of June 2004: Still Second-Order?”, (2005) 28 West European Politics, pp. 650-679.

P. Schmitter, "Political Accountability in 'Real-Existing' Democracies: Meaning and Mechanisms", (2007), available at: <www.eui.eu/Documents/DepartmentsCentres/SPS/Profiles/Schmitter/PCSPoliticalAccountabilityJan07.pdf> (last retrieved on 10 September 2014).

M. Shackleton, “The European Parliament”, in J. Petersen, M. Shackleton (eds.), The Institutions of the European Union, $3^{\text {rd }}$ ed., Oxford University Press: Oxford, 2012, pp. 124-147.

S. Sieberson, “The Treaty of Lisbon and its Impact on the European Union's Democratic Deficit”, (2008) 14 Columbia Journal of European Law, pp. 445-465.

S. Siefken, "Parlamentarische Frageverfahren - Symbolpolitik oder wirksames Kontrollinstrument?”, (2010) Zeitschrift für Parlamentsfragen, pp. 18-36.

S. Siefken, "Konfigurationen parlamentarischer Kontrolle: Ein Konzept für die vergleichende Analyse”, in B. Eberbach-Born, S. Kropp, A. Stuchlik, W. Zeh (eds.), Parlamentarische Kontrolle und Europäische Union, Nomos: Baden-Baden, 2013, pp. 49-78.

C. Sprungk, "Ever More or Ever Better Scrutiny? Analysing the Conditions of Effective National Parliamentary Involvement in EU Affairs", (2010) 14 European Integration online Papers (EIoP).

B. Steunenberg, J.A.A. Thomassen (eds.), The European Parliament: Moving Toward Democracy in the EU, Rowman \& Littlefield Publishers: Oxford, 2002.

M. Stewart, "Direct Elections to the European Parliament (With special Reference to the United Kingdom)”, (1976) 13 Common Market Law Review, pp. 283-299.

K. Strom, W. Müller, T. Bergman (eds.), Delegation and Accountability in Parliamentary Democracies, Oxford University Press: New York, USA, 2006.

C. Syrier, The Investigative Function of the European Parliament: Holding the EU Executive to Account by Conducting Investigations, Wolf Legal Publishers: The Netherlands, 2013. 
J. Tallberg, "Bargaining Power in the European Council”, (2008) 46 Journal of Common Market Studies, pp. 685-708.

M. Van den Steeg, "Public Accountability in the European Union: Is the European Parliament able to hold the European Council accountable?", (2009) 13 European Integration Online Papers.

S. Verhelst, "The Sense and Nonsense of Eurozone Level Democracy", (2014) Egmont Paper 70.

L. Verhey, "Political Accountability: A Useful Concept in EU Inter-Institutional Relations?", in L. Verhey, P. Kiiver, S. Loeffen (eds.), Political Accountability and European Integration, Europa Law Publishing: Groningen, 2009, pp. 57-70.

L. Verhey, "Fostering Executive Accountability in the EU: A Key Issue", in J.Wouters, L. Verhey, P. Kiiver (eds.), European Constitutionalism beyond Lisbon, Intersentia: Antwerp, 2009, pp. 239-258.

W. Voermans, "Is the European Legislator after Lisbon a real Legislature?", (2011) 17 The Brown Journal of World Affairs, pp. 163-180.

H.J. Vonderbeck, Parlamentarische Informations- und Redebefugnisse, Duncker \& Humblot: Berlin, 1981. Union, Nomos: Baden-Baden, 2013.

D. Watts, C. Pilkington, Britain in the European Union Today, Manchester University Press: Manchester, 2005.

J.H.H. Weiler, “After Maastricht: Community Legitimacy in Post-1992 Europe”, in W.J. Adams (ed.), Singular Europe - Economy and Polity of the European Community After 1992, University of Michigan Press: USA, 1995, pp. 11-42.

J.H.H. Weiler, U. Haltern, F. Mayer, "European Democracy and its Critique - Five uneasy Pieces”, (1995) European University Institute Working Paper RSC No. 95/11.

W. Wessels, U. Diedrichs, “A New Kind of Legitimacy for a New Kind of Parliament The Evolution of the European Parliament”, (1997) 1 European Integration Online Papers. 
W. Wessels, O. Rozenberg, M. Van den Berge, C. Hefftler, V. Kreilinger, L. Ventura, "Democratic Control in the Member States of the European Council and the Euro Zone Summits“, (2013) Study for the European Parliament's Committee on Constitutional Affairs.

W. Wessels, "National Parliaments and the EP in Multi-Tier Governance: In Search for an Optimal Multi-Level Parliamentary Architecture", (2013) European Parliament Report, Challenges of Multi-Tier Governance in the European Union - Effectiveness, Efficiency and Legitimacy, Compendium of Notes, pp. 95-110.

P. De Wilde, C. Lord, "Assessing Actually-Existing Trajectories of EU Politicization”, (2016) 39 West European Politics, pp. 145-163.

A. Wimmel, "Theorizing the Democratic Legitimacy of European Governance: a Labyrinth with No Exit?”, (2009) 31 European Integration, pp. 181-199.

T. Winzen, "National Parliamentary Control of European Union Affairs: A Cross-National and Longitudinal Comparison", (2012) 35 West European Politics, pp. 657-672.

T. Winzen, "European Integration and National Parliamentary Oversight Institutions", (2013) 14 European Union Politics, pp. 297-323.

B. De Witte, A.H. Trechsel, D. Damjanovic, E. Hellquist, J. Hien, P. Ponzano, "Legislating After Lisbon - New Opportunities for the European Parliament", (2010) Study prepared in the framework of the European Union Democracy Observatory (EUDO), Florence.

\section{E INTERNET WEBSITES}

Bundestag website, Ausschuss für die Angelegenheiten der Europäischen Union, available at: <https://www.bundestag.de/bundestag/ausschuesse18/a21/aufgaben_und_arbeit/aufgaben_und_arbeit/214768> (last retrieved on 11 September 2014).

Bundestag website, Der Bundestag stärkt seine Europa-Expertise, available at: <https://www.bundestag.de/dokumente/textarchiv/2013/47765815_kw47_ua_ europa/214002> (last retrieved on 13 February 2018).

Bundestag website, Die Verwaltung des Deutschen Bundestages, available at: $<$ https://www.bundestag.de/parlament/verwaltung > (last retrieved on 11 February 2018). 
Bundestag website, Instruments of scrutiny, available at: $<$ https://www.bundestag.de/en/parliament/function/scrutiny/instruments_scrutiny/245710> (last retrieved on 12 February 2018).

Bundestag website, Mitarbeiter, available at: <https://www.bundestag.de/abgeordnete/ mdb_diaeten/1334d/260806> (last retrieved on 13 February 2018).

Bundestag website, Table of Organisation, available at: <www.bundestag.de/blob/ 189738/5f4ad574dc0367e0b94830715585bcf0/orgplan-en-data.pdf> (last retrieved on 13 February 2018).

European Commission website, ERM II - The EU's Exchange Rate Mechanism, available at: $<$ https://ec.europa.eu/info/business-economy-euro/euro-area/enlargement-euro-area/ introducing-euro/adoption-fixed-euro-conversion-rate/erm-ii-eus-exchange-ratemechanism_en> (last retrieved on 2 March 2018).

European Commission website, Six-Pack? Two-Pack? Fiscal Compact? A Short Guide to the New Fiscal Governance, available at: $<$ http://ec.europa.eu/economy_finance/articles/governance/2012-03-14_six_pack_en.htm> (last retrieved on 1 May 2016).

European Commission website, The Subsidiarity Control Mechanism, available at: $<$ http://ec.europa.eu/dgs/secretariat_general/relations/relations_other/npo/subsidiarity_en.htm> (last retrieved on 1 May 2016).

European Commission website, The Political Dialogue, available at: $<$ http://ec.europa.eu/dgs/secretariat_general/relations/relations_other/npo/political_dialogue_en.htm\#politicaldialogue> (last retrieved on 1 May 2016).

European Council website, Declaration Bulgaria, available at: <www.consilium.europa.eu/en/documents-publications/agreements-conventions/ratification/?v=decl\&aid=2012008\&pid=BG $>$ (last retrieved on 1 May 2016).

European Council website, Declaration Denmark, available at: <www.consilium.europa.eu/en/documents-publications/agreements-conventions/ratification $/ \mathrm{v}=$ decl\&aid=2012008\&pid=DK $>$ (last retrieved on 1 May 2016).

European Council website, Declaration Romania, available at: <www.consilium.europa.eu/en/documents-publications/agreements-conventions/ratification $/$ ?v=decl\&aid=2012008\&pid=RO $>$ (last retrieved 1 May 2016). 
European Financial Stability Facility website, About EFSF, available at: $<$ www.efsf.europa.eu/about/index.htm > (last retrieved on 1 May 2016).

European Parliament website, Conference of Speakers of EU Parliaments, available at: $<$ www.europarl.europa.eu/webnp/cms/pid/8;jsessionid=039B36380637B5C28EB5148 DC804063F $>$ (last retrieved on 1 May 2016).

European Parliament website, Conference of Parliamentary Commitees for Union Affairs (COSAC), available at: <www.europarl.europa.eu/webnp/cms/pid/9> (last retrieved on 1 May 2016).

European Parliament website, European Parliamentary Week 2016, available at: $<$ www.europarl.europa.eu/relnatparl/en/conferences/european-parliamentary-week.html> (last retrieved on 1 May 2016).

European Parliamentary Week website, available at: <www.epgenpro.europarl. europa.eu/static/relnatparl/en/conferences/european-parliamentary-week.html> (last retrieved on 1 May 2017).

European University Institute website, Constitutional Change through Euro Crisis Law: Greece - Fiscal Compact, available at: <http://eurocrisislaw.eui.eu/country/greece/topic/fiscal-compact/> (last retrieved on 1 May 2016).

Financial Times website, Irish angry over budget leak to Germany, available at: $<$ https://www.ft.com/content/bd9ab93a-11fb-11e1-a114-00144feabdc0> (last retrieved on 31 July 2017).

M. Sarrazin website, The Case for Democratic Economic Governance in the EU-27, available at: <https://manuelsarrazin.de/2012/11/08/case-democratic-economic-governance-eu27> (last visited 31 March 2017).

Oireachtas website, Consideration of EU Matters by Sectoral Committees, available at: $<$ www.oireachtas.ie/parliament/oireachtasbusiness/www.oireachtas/committees/europeanunion/scrutinyprocess $>$ (last retrieved on 15 May 2015).

Oireachtas website, Organisation Chart 2018, available at: <www.oireachtas.ie/parliament/media/ 8544498.pdf> (last retrieved on 14 February 2018). 
AN UNEVEN BALANCE?

Oireachtas website, Parliamentary Questions, available at: <www.oireachtas.ie/parliament/oireachtasbusiness/parliamentaryquestions> (last retrieved on 15 May 2015).

Oireachtas website, The Houses of the Oirachtas Service, available at: <www.oireachtas.ie/parliament/about/parliamentaryadministration/> (last retrieved on 14 February 2018).

The Guardian website, Ireland's budget leak to Germany brings home some harsh realities, available at: $<$ https://www.theguardian.com/commentisfree/2011/nov/18/ireland-budgetgermany-leak> (last retrieved on 31 July 2017). 


\section{Summary}

The purpose of this book is to analyze and understand the formal power asymmetries that exist between the national parliaments in the European Union, and to consider the implications of such asymmetries for representative democracy in the EU. It takes the European sovereign debt crisis as a cause to look into this particular issue because of the asymmetric impact that the latter had on the different national parliaments. As an addition to this analysis, the book in the end also illustrates different ways in which the negative implications for EU representative democracy that result from the described power asymmetries between national parliaments could be mitigated.

The book starts with a discussion of the concept of representative democracy and explains the link between the notions of representation, accountability and responsibility thereunder, before it looks at the concept of representative democracy within the context of the European Union. It then describes the role of the European Parliament and the national parliaments as the two kinds of representative organs in the EU by looking at their historical development and outlining their current role and powers under the Treaties.

Chapters 4 and 5 then take a closer look at two specific national parliaments and compares their respective (formal) powers in relation to EU affairs. To that end, first a conceptual overview of the powers of national parliaments in domestic constitutional law is provided. Second, the constitutional frameworks under which the German Bundestag and the Irish Dáil Eireann participate in EU matters is examined with a special focus on their scrutiny powers vis-à-vis their governments in such matters. The comparative analysis shows that while the constitutional rules differ between the two respective parliaments one example is the lack of a binding mandating power in the Irish parliament, which does exist in Germany - much of the difference in power can also be attributed to the political traditions of the respective Member States. In the Irish Dáil, issues relating to European affairs are not often considered to be high on the parliament's agenda. This is, inter alia, the result of the way the members of parliament in Ireland are elected, as elections are often won (and indeed lost) on constituency issues. The German Bundestag, on the other hand, enjoys a very strong position in EU affairs vis-à-vis the German government, which is in part also due to the requirements that have been promulgated by the German Federal Constitutional Court in this regard.

The differences in power between national parliaments therefore have very different reasons. The comparison of these two national parliaments shows that even before the crisis response measures were adopted at EU level, which considerably exacerbated asymmetries in national parliaments' powers, there existed much difference in participation powers of national parliaments with regards to EU matters. From the beginning of the 
European project, the concept of dual representative democracy in the EU has never been homogeneous for all Member States. The line of democratic representation that is provided by the European Parliament is arguably, and at least insofar as it is envisioned in the Treaties, the same for all Union citizens. Leaving aside some issues with the way in which the EP is elected, Article 14(2) TEU unmistakably makes it clear that the Parliament is composed of representatives of the Union's citizens as a whole. This strand of democratic representation in the EU does not differentiate between the citizens of the different Member States.

This is different for the second line of representation that is provided for by the national parliaments when they hold their national governments to account for actions in the Council and the European Council. Because the conditions under which the national parliaments can scrutinize and control the latter is, and has always been, dependent on their respective constitutional framework as well as the political traditions in the Member State itself, the degree of representation for the citizens under this second strand differed, and still differs, from one Member State to the next. This changed to a certain extent with the beginning of the European sovereign debt crisis in 2009 and with the various instruments that were adopted as a response thereto, which transferred some of the roots of such asymmetries from the national level to the European level.

In this regard, Chapter 6 examines more closely the way in which the crisis and the crisis response measures have affected this second line of democratic representation that is provided by the national parliaments. By analyzing the legal provisions of the European Stability Mechanism (ESM), the Treaty on Stability, Coordination and Governance in the Economic and Monetary Union (TSCG), the Six-Pack, and the Two-Pack, this chapter shows that the impact of these instruments on national parliaments varied greatly from parliament to parliament. Whether or not a parliament saw its budgetary and legislative powers eroded depended on a number of factors, but not least on the economic strength of its constituent Member State and whether or not its Member State had adopted the common currency. The chapter concludes that the asymmetric impact of the crisis on the different national parliaments increased already existing power asymmetries between national parliaments in the EU and, as a consequence, also had implications for the concept of dual democratic representation in the European Union. The question is thus asked as to whether or not it is possible to talk about two lines of democratic representation if, in fact, for some national parliaments such a second line does not actually exist, or at least was temporarily suspended during the Euro crisis. Instead, the citizens of those parliaments witnessed their national parliament retreat into the backbenches and, in the worst case, being dictated by the demands of other parliaments.

The seventh and last chapter looks into this problem further and first analyzes the implications of the asymmetries described in Chapter 6 for (dual) representative democracy in the EU and the Eurozone. The main implications are the disruption of the chain of 
accountability and thus a disruption of the notion of representation under the concept of representative democracy because in an ever more intertwined EU, and especially in an ever more intertwined Eurozone, the national governments are no longer only responsible to their own national electorates. They also have to consider the preferences of the other Member States, who are affected by their decisions, all the while the power of national parliaments to participate in such decisions becomes increasingly differentiated. In a second instance, the chapter then assesses three different proposals for the future role of parliaments in the EU so as to mitigate the effects of such power asymmetries between national parliaments on EU representative democracy; namely the strengthening of the powers of the European Parliament, the creation of a new parliament for the Eurozone and the strengthening of the national parliaments though interparliamentary cooperation. 



\section{Curriculum Vitae}

Thu Nguyen was born in September 1990 in Aachen, Germany. She graduated with a LL.B. (cum laude) from the European Law School at Maastricht University in 2012 and obtained a LL.M. from the College of Europe (Bruges campus) in 2013. During her studies she spent one semester at the Université of Rennes. In August 2013 she joined the Department of Public Law at Maastricht University as a PhD candidate, where she completed this thesis in January 2018. She remains with the Department of Public Law as an Assistant Professor. Thu Nguyen is a fellow of the Montesquieu Institute Maastricht. 



\section{AdDENDUM ON VAlorization}

Valorization is the "process of creating value from knowledge, by making knowledge suitable and/or available for social (and/or economic) use and by making knowledge suitable for translation into competitive products, services, processes and new commercial activities." In the following, the valorization of this doctoral thesis will be explained with regard to its (1) relevance, (2) target groups, (3) activities/products, (4) innovation and (5) schedule and implementation.

\section{Relevance:}

The purpose of this doctoral thesis is to analyze and understand the formal power asymmetries that exist between the national parliaments in the European Union and to consider the implications of such asymmetries for representative democracy in the EU. It takes the European sovereign debt crisis as a cause to look into this particular issue because of the asymmetric impact that it had on the different national parliaments. In addition to this analysis, the book in the end also illustrates different ways in which the negative implications for EU representative democracy, which result from the described power asymmetries between national parliaments, could be mitigated.

The societal relevance of this dissertation lies in its contribution to the European-wide debates on the state of democracy in the European Union, which has become particularly salient after the financial and sovereign debt crisis in Europe. As democracy concerns politicians, academics and the average citizen alike, this is an issue that has not only occupied academic scholars in the field of European studies for decades but also has an immediate impact on society and the general population in Europe as a whole. A very clear example of the societal relevance of this topic was the public outrage in Ireland in 2011, when it became known that the Irish draft budget had been sent to a committee of the German Bundestag before it was even presented to the Irish parliament, and claims were made that the Irish government had surrendered its sovereignty to other European governments. But one could also think of the situation in Greece following its request for financial assistance, when it had to submit to a series of stringent conditions, austerity measures, and structural reforms under the monitoring eyes of the European Commission, the International Monetary Fund and the European Central Bank, which led to a general feeling of resentment towards the EU in more than just one Member State.

The negative image that the EU finds itself faced with, and in particular in regards its democratic credentials, obscure and often make forgotten the benefits that it has in fact 
to offer to its citizens. For that reason the EU's image in the eyes of the general EU population must be improved and the benefits of its membership must be better communicated to the public by both European and national politicians. This also means that a thorough analysis of the current state of democracy in the EU is indispensable because it allows policy-makers in Europe to examine and reflect on the results of this analysis in order to implement the necessary policy changes on the basis thereof, also to avoid the further surge of populism, the roots of which can be, amongst others, found in Euroskepticism.

\section{TARGET GROUPS:}

In addition to the academic community, the results of this doctoral dissertation are also of interest to policy-makers at both the national level and the European level. Improving the state of democracy in the EU and re-evaluating the role and function of both the national parliaments and the European Parliament within its system of governance is a concern that cannot be addressed by either the national or the European level alone. Rather, policy-makers of all 28 (soon 27) Member States and policy-makers on EU level must work together to reflect on the policy changes necessary to improve the state of democracy in the EU. The results of this doctoral dissertation is of particular interests for policy-makers working in the national parliaments in the EU as much of its analyses relates to national parliamentary functions in European Union affairs and to how these functions could be improved. In addition, it can also be of interest to the general population in the European Union who would like to gain a deeper understanding of the democratic structures that exist in the EU - especially in light of the upcoming elections of the European Parliament in May 2019 - and in particular of the role of national parliaments in the European Union.

\section{Activities/Products:}

The concrete products that result from this doctoral dissertation are policy recommendations addressed to parliaments and governments in the EU. Its results can best be implemented through policy changes at both the national level and the European level. Following an analysis of power asymmetries between national parliaments in the EU, the creation of a new interparliamentary conference for the national parliaments of the Eurozone Member States and the European Parliament was recommended. A concrete product or activity that could be envisioned on the basis of this doctoral dissertation would therefore be the creation of such a conference, although this is not strictly necessary. Also the enhanced use of the current structures, even in an informal basis, could be considered a direct translation of the results of this book into concrete processes or activities. 


\section{INNOVATION:}

Such reinforced interparliamentary cooperation - either formal or informal -, as would be resulting from this book and was described above, would be innovative insofar as it would be a new attempt at re-designing the role of national parliaments in the EU through a new addition to or a new enhancement of the existing parliamentary structures.

\section{SChedule AND implementation:}

The policy changes that could result from the recommendations made in this doctoral thesis, i.e. strengthened interparliamentary cooperation through a new conference or through an enhanced use of the current structures, are dependent on the agreement and participation of 28 (soon 27) national parliaments as well as the European Parliament. As these are political institutions, each with their own interests, priorities, agendas and internal will formation processes, it is impossible to predict either a schedule for the implementation of the recommendations or the costs that such an implementation would entail. It is conceivable, however, that the upcoming European Parliament elections in May 2019 and the subsequent changes in the composition of the European Commission would constitute a good point in time to take up the discussions on the nature of democracy in the European Union and to re-evaluate the role of national parliaments in the EU, in which case this book could not have been published at a much better time.

As to the market opportunities that are involved with the topic of this doctoral dissertation, there are none. One should point out, however, that it does seem somewhat contradictory to ask of a doctoral thesis, which has as its primary purpose the demonstration of the doctoral candidate's ability to independently carry out scholarly research, to contribute to the creation of market opportunities. A doctoral dissertation, just as any other form of scholarly research, should have as its objective the critical and nonpartisan discussion or analysis of a particular issue in the field of science in which the dissertation is located. An obligation or encouragement to conduct such research in a manner that it should lead to the creation of monetary value or market opportunities would stand in the way of such an objective and should therefore not be supported - in particular not in times of rising populism and 'alternative facts' where a well-researched doctoral thesis should be appreciated for being exactly that, namely a well-executed piece of objective scholarly research contributing to the academic debate on its field. 